Prepared in cooperation with the New Jersey Pinelands Commission

\title{
Hydrogeologic Framework in Three Drainage Basins in the New Jersey Pinelands, 2004-06
}

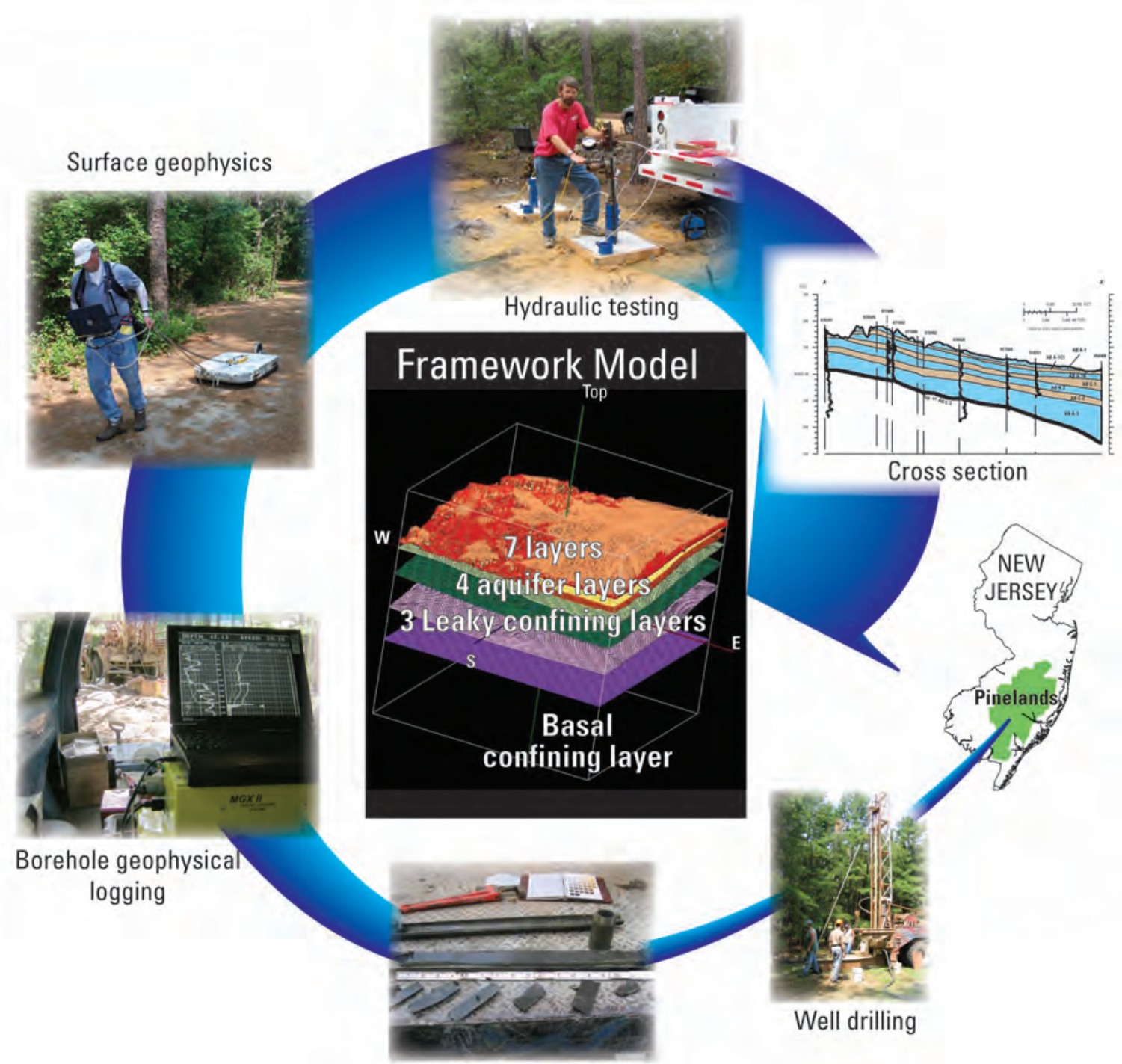

Core samples

Scientific Investigations Report 2008-5061 
Cover: All photographs courtesy of USGS. 


\section{Hydrogeologic Framework in Three Drainage Basins in the New Jersey Pinelands, 2004-06}

By Richard L. Walker, Pamela A. Reilly, and Kara M. Watson

Prepared in cooperation with the

New Jersey Pinelands Commission

Scientific Investigations Report 2008-5061 


\title{
U.S. Department of the Interior DIRK KEMPTHORNE, Secretary
}

\author{
U.S. Geological Survey \\ Mark D. Myers, Director
}

U.S. Geological Survey, Reston, Virginia: 2008

For product and ordering information:

World Wide Web: http://www.usgs.gov/pubprod

Telephone: 1-888-ASK-USGS

For more information on the USGS - the Federal source for science about the Earth,

its natural and living resources, natural hazards, and the environment:

World Wide Web: http://www.usgs.gov

Telephone: 1-888-ASK-USGS

Suggested citation:

Walker, R.L., Reilly, P.A., Watson, K.M., 2008, Hydrogeologic framework in three drainage basins in the New Jersey

Pinelands, 2004-06: U.S. Geological Survey Scientific Investigations Report 2008-5061, 147 p.

Any use of trade, product, or firm names is for descriptive purposes only and does not imply endorsement by the U.S. Government. Use of company names is for identification purposes only and does not imply responsibility.

Although this report is in the public domain, permission must be secured from the individual copyright owners to reproduce any copyrighted material contained within this report. 


\section{Contents}

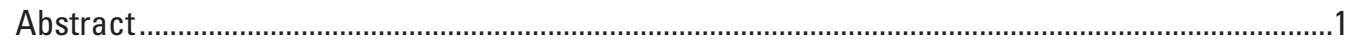

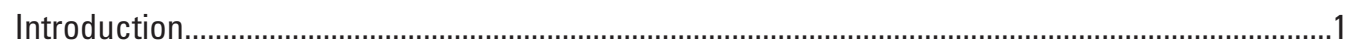

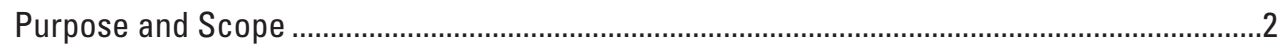

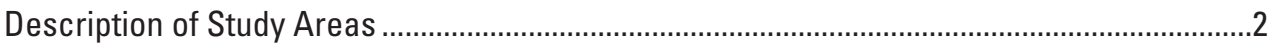

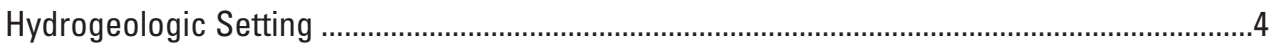

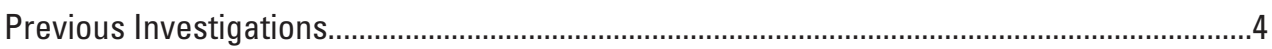

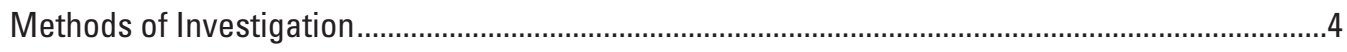

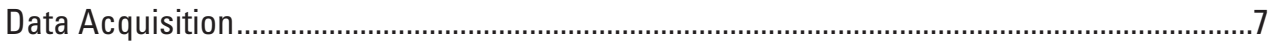

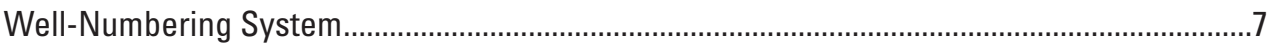

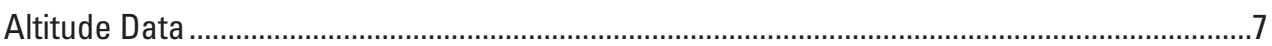

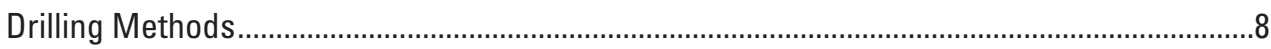

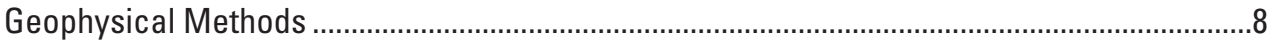

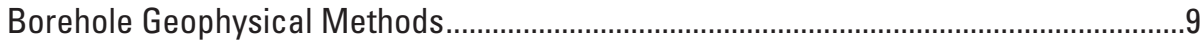

Surface Geophysical Methods .........................................................................................

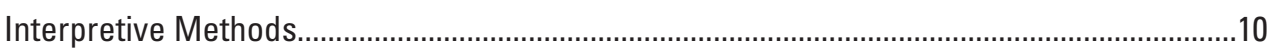

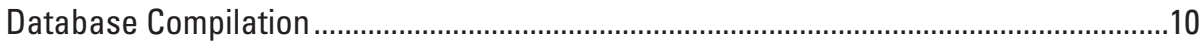

Development of the Hydrogeologic Framework .............................................................10

Mapping Hydrogeologic Framework Layers ............................................................11

Hydrogeologic Sections .......................................................................................... 11

Determination of Aquifer System Properties .................................................................12

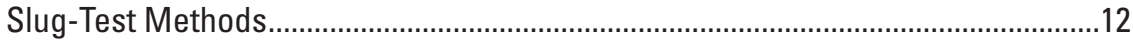

Slug-Test Analysis ............................................................................................. 12

Well-Performance Tests ............................................................................................ 13

Estimation of Spatial Variability of Aquifer System Properties .........................................16

Hydrogeologic Framework ........................................................................................16

Hydrogeology of Albertson Brook Study Area and Vicinity.......................................................17

Hydrogeology of McDonalds Branch Study Area and Vicinity..................................................32

Hydrogeology of Morses Mill Stream Study Area and Vicinity..................................................41

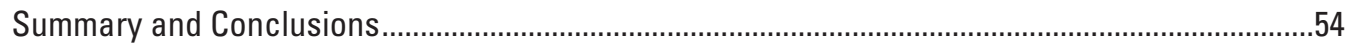

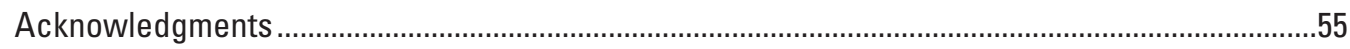

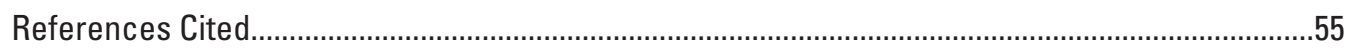

Appendix 1 Lithologic and geophysical logs of selected boreholes and newly installed wells in Kirkwood-Cohansey aquifer system, New Jersey Pinelands ................................80

Appendix 2 Altitude, thickness, estimated sand content, and (or) horizontal hydraulic conductivity of hydrogeologic layers of the Kirkwood-Cohansey aquifer system, Albertson Brook study area and vicinity, New Jersey Pinelands

Appendix 3 Altitude, thickness, estimated sand content, and (or) horizontal hydraulic conductivity of hydrogeologic layers of the Kirkwood-Cohansey aquifer system, McDonalds Branch study area and vicinity, New Jersey Pinelands

Appendix 4 Altitude, thickness, estimated sand content, and (or) horizontal hydraulic conductivity of hydrogeologic layers of the Kirkwood-Cohansey aquifer system, Morses Mill Stream study area and vicinity, New Jersey Pinelands. 


\section{Figures}

1. Map showing location of the Pinelands study areas, Atlantic, Burlington, and Camden Counties, New Jersey.

2. (a) Generalized hydrogeologic section through the New Jersey Coastal Plain and (b) line of section.

3-7. Maps showing-

3. Location of wells with horizontal hydraulic-conductivity data, Albertson Brook study area and vicinity, New Jersey Pinelands.

4. Location of wells with horizontal hydraulic-conductivity data, McDonalds Branch study area and vicinity, New Jersey Pinelands

5. Location of wells with horizontal hydraulic-conductivity data, Morses Mill Stream study area and vicinity, New Jersey Pinelands.

6. Location of boreholes, wells, and ground-penetrating radar (GPR) data points used to describe the hydrogeologic framework of the Albertson Brook study area and vicinity, New Jersey Pinelands

7. Location of hydrogeologic lines of section, and wells or boreholes with lithologic or geophysical data, Albertson Brook study area and vicinity,

New Jersey Pinelands.

8-11. Sections showing-

8. Hydrogeologic section $A-A^{\prime}$, Albertson Brook study area and vicinity, New Jersey Pinelands

9. Hydrogeologic section $B-B^{\prime}$, Albertson Brook study area and vicinity, New Jersey Pinelands

10. Hydrogeologic section $C$ - $C^{\prime}$, Albertson Brook study area and vicinity, New Jersey Pinelands.

11. Hydrogeologic section $D-D^{\prime}$, Albertson Brook study area and vicinity, New Jersey Pinelands.

12-14. Maps showing-

12. Results of ground-penetrating radar (GPR) surveys used to describe the hydrogeologic framework of the Albertson Brook study area and vicinity, New Jersey Pinelands.

13. Location of boreholes, wells, and ground-penetrating radar (GPR) data points used to describe the hydrogeologic framework of the McDonalds Branch study area and vicinity, New Jersey Pinelands

14. Location of hydrogeologic lines of section, and wells or boreholes with lithologic or geophysical data, McDonalds Branch study area and vicinity, New Jersey Pinelands.

15-18. Sections showing-

15. Hydrogeologic section $A-A^{\prime}$, McDonalds Branch study area and vicinity, New Jersey Pinelands.

16. Hydrogeologic section $B-B^{\prime}$, McDonalds Branch study area and vicinity, New Jersey Pinelands

17. Hydrogeologic section $C-C^{\prime}$, McDonalds Branch study area and vicinity, New Jersey Pinelands

18. Hydrogeologic section $D-D^{\prime}$, McDonalds Branch study area and vicinity, New Jersey Pinelands. 
19-21. Maps showing-

19. Results of ground-penetrating radar (GPR) surveys used to describe the hydrogeologic framework of the McDonalds Branch study area and vicinity, New Jersey Pinelands

20. Location of boreholes, wells, and ground-penetrating radar (GPR) data points used to describe the hydrogeologic framework of the Morses Mill Stream study area and vicinity, New Jersey Pinelands

21. Location of hydrogeologic lines of section, and wells or boreholes with lithologic or geophysical data, Morses Mill Stream study area and vicinity, New Jersey Pinelands.

22-25. Sections showing-

22. Hydrogeologic section $A-A^{\prime}$, Morses Mill Stream study area and vicinity, New Jersey Pinelands.

23. Hydrogeologic section $B-B^{\prime}$, Morses Mill Stream study area and vicinity, New Jersey Pinelands.

24. Hydrogeologic section $C$ - $C^{\prime}$, Morses Mill Stream study area and vicinity, New Jersey Pinelands.

25. Hydrogeologic section $D-D^{\prime}$, Morses Mill Stream study area and vicinity, New Jersey Pinelands.

26. Map showing results of ground-penetrating radar (GPR) surveys used to describe the hydrogeologic framework of the Morses Mill Stream study area and vicinity, New Jersey Pinelands 


\section{Tables}

1. Geologic and hydrogeologic units in the New Jersey Coastal Plain in

New Jersey

2. Records of selected hydrologic investigation sites used to describe the hydrogeologic framework of the Kirkwood-Cohansey aquifer system in Pinelands study areas and vicinity, New Jersey

3. Estimated horizontal hydraulic conductivities and details of slug test for the $\mathbf{1 6}$ new wells installed in the Kirkwood-Cohansey aquifer system, Pinelands study areas, New Jersey

4. Estimated hydraulic conductivity (K) values for sites in the Pinelands study areas and vicinity, New Jersey

5. Altitudes of tops of hydrogeologic layers of the Kirkwood-Cohansey aquifer system, Albertson Brook study area and vicinity, New Jersey Pinelands.

6. Altitudes of tops of hydrogeologic layers of the Kirkwood-Cohansey aquifer system at selected wells in the McDonalds Branch study area and vicinity, New Jersey Pinelands

7. Altitudes of tops of hydrogeologic layers of the Kirkwood Cohansey aquifer system, Morses Mill study area and vicinity, New Jersey Pinelands 


\section{Conversion Factors and Datum}

Inch/Pound to SI

\begin{tabular}{|c|c|c|}
\hline Multiply & By & To obtain \\
\hline \multicolumn{3}{|c|}{ Length } \\
\hline inch (in.) & 2.54 & centimeter (cm) \\
\hline inch (in.) & 25.4 & millimeter (mm) \\
\hline foot $(\mathrm{ft})$ & 0.3048 & meter (m) \\
\hline mile (mi) & 1.609 & kilometer (km) \\
\hline \multicolumn{3}{|c|}{ Area } \\
\hline square mile $\left(\mathrm{mi}^{2}\right)$ & 259.0 & hectare (ha) \\
\hline square mile $\left(\mathrm{mi}^{2}\right)$ & 2.590 & square kilometer $\left(\mathrm{km}^{2}\right)$ \\
\hline \multicolumn{3}{|c|}{ Volume } \\
\hline gallon (gal) & 3.785 & liter (L) \\
\hline gallon (gal) & 0.003785 & cubic meter $\left(\mathrm{m}^{3}\right)$ \\
\hline gallon (gal) & 3.785 & cubic decimeter $\left(\mathrm{dm}^{3}\right)$ \\
\hline \multicolumn{3}{|c|}{ Flow rate } \\
\hline gallon per minute (gpm) & 0.06309 & liter per second (L/s) \\
\hline gallon per day (gpd) & 0.003785 & cubic meter per day $\left(\mathrm{m}^{3} / \mathrm{d}\right)$ \\
\hline \multicolumn{3}{|c|}{ Pressure } \\
\hline pound per square inch (lb/in²) & 6.895 & kilopascal (kPa) \\
\hline \multicolumn{3}{|c|}{ Specific capacity } \\
\hline gallon per minute per foot $[(\mathrm{gal} / \mathrm{min}) / \mathrm{ft})]$ & 0.2070 & liter per second per meter $[(\mathrm{L} / \mathrm{s}) / \mathrm{m}]$ \\
\hline \multicolumn{3}{|c|}{ Hydraulic conductivity } \\
\hline foot per day (ft/d) & 0.3048 & meter per day $(\mathrm{m} / \mathrm{d})$ \\
\hline \multicolumn{3}{|c|}{ Transmissivity* } \\
\hline foot squared per day $\left(\mathrm{ft}^{2} / \mathrm{d}\right)$ & 0.09290 & meter squared per day $\left(\mathrm{m}^{2} / \mathrm{d}\right)$ \\
\hline \multicolumn{3}{|c|}{ Velocity } \\
\hline foot per microsecond (ft/ $\mu \mathrm{s})$ & 0.3048 & meter per microsecond (m/ $/ \mu \mathrm{s})$ \\
\hline
\end{tabular}

Vertical coordinate information is referenced to the North American Vertical Datum of 1988 (NAVD 88).

Horizontal coordinate information is referenced to the North American Datum of 1983 (NAD 83).

Altitude, as used in this report, refers to distance above the vertical datum.

*Transmissivity: The standard unit for transmissivity is cubic foot per day per square foot times foot of aquifer thickness $\left[\left(\mathrm{ft}^{3} / \mathrm{d}\right) / \mathrm{ft}^{2}\right] \mathrm{ft}$. In this report, the mathematically reduced form, foot squared per day $\left(\mathrm{ft}^{2} / \mathrm{d}\right)$, is used for convenience. 



\title{
Hydrogeologic Framework in Three Drainage Basins in the New Jersey Pinelands, 2004-06
}

\author{
By Richard L. Walker, Pamela A. Reilly, and Kara M. Watson
}

\section{Abstract}

The U.S. Geological Survey, in cooperation with the New Jersey Pinelands Commission, began a multi-phase hydrologic investigation in 2004 to characterize the hydrologic system supporting the aquatic and wetland communities of the New Jersey Pinelands area (Pinelands). The Pinelands is an ecologically diverse area in the southern New Jersey Coastal Plain underlain by the Kirkwood-Cohansey aquifer system. The demand for ground water from this aquifer system is increasing as local development increases. To assess the effects of ground-water withdrawals on Pinelands stream and wetland water levels, three drainage basins were selected for detailed hydrologic assessments, including the Albertson Brook, McDonalds Branch and the Morses Mill Stream basins. Study areas were defined surrounding the three drainage basins to provide sub-regional hydrogeologic data for the ground-water flow modeling phase of this study.

In the first phase of the hydrologic assessments, a database of hydrogeologic information and a hydrogeologic framework model for each of the three study areas were produced. These framework models, which illustrate typical hydrogeologic variations among different geographic sub-regions of the Pinelands, are the structural foundation for predictive groundwater flow models to be used in assessing the hydrologic effects of increased ground-water withdrawals.

During 2004-05, a hydrogeologic database was compiled using existing and new geophysical and lithologic data including suites of geophysical logs collected at 7 locations during the drilling of 21 wells and one deep boring within the three study areas. In addition, 27 miles of ground-penetrating radar (GPR) surface geophysical data were collected and analyzed to determine the depth and extent of shallow clays in the general vicinity of the streams. On the basis of these data, the Kirkwood-Cohansey aquifer system was divided into 7 layers to construct a hydrogeologic framework model for each study area. These layers are defined by their predominant sediment textures as aquifers and leaky confining layers. The confining layer at the base of the KirkwoodCohansey aquifer system, depending on location, is defined as one of two distinct clays of the Kirkwood Formation. The framework models are described using hydrogeologic sec- tions, maps of structure tops of layers, and thickness maps showing variations of sediment textures of the various model layers. The three framework models are similar in structure but unique to their respective study areas.

The hydraulic conductivity of the Kirkwood-Cohansey aquifer system in the vicinity of the three study areas was determined from analysis of 16 slug tests and 136 well-performance tests. The mean values for hydraulic conductivity in the three study areas ranged from about 84 feet per day to 130 feet per day.

With the exception of the basal confining layers, the variable and discontinuous nature of clay layers within the Kirkwood-Cohansey aquifer system was confirmed by the geophysical and lithologic records. Leaky confining layers and discontinuous clays are generally more common in the upper part of the aquifer system. Although the Kirkwood-Cohansey aquifer system generally has been considered a water-table aquifer in most areas, localized clays in the aquifer layers and the effectiveness of the leaky confining layers may act to impede the flow of ground water in varying amounts depending on the degree of confinement and the location, duration, and magnitude of the hydraulic stresses applied.

Considerable variability exists in the different sediment textures. The extent to which this hydrogeologic variability can be characterized is constrained by the extent of the available data. Thus, the hydraulic properties of the modeled layers were estimated on the basis of available horizontal hydraulic conductivity data and the range of sediment textures estimated from geophysical and lithologic data.

\section{Introduction}

The New Jersey Pinelands area (Pinelands) (fig.1) is a 1.1-million-acre natural reserve area in southern New Jersey that overlies the Kirkwood-Cohansey aquifer system in the Atlantic Coastal Plain (fig. 2) (New Jersey Pinelands Commission, 1981). This ecologically diverse area supports a variety of habitats and is home to many threatened and endangered species. Cedar swamps, pine and oak forests, agricultural areas, and newly developed commercial and residential areas dominate the landscape. Demand for water from the Kirk- 
wood-Cohansey aquifer system is increasing as development within the area increases.

The Pinelands Commission has been tasked with evaluating increased water-supply demands within the Pinelands area with respect to the potential of adverse effects on the hydrologic and ecological systems in the area. The relation between key hydrologic and ecological attributes needs to be characterized to (1) assess the effects of ground-water diversions from the Kirkwood-Cohansey aquifer system on stream and wetland water levels within the Pinelands, and (2) determine the potential ecological effects of reduced water levels on aquatic and wetland communities (New Jersey Pinelands Commission, 2003). Therefore, the U.S. Geological Survey (USGS), in cooperation with the Pinelands Commission, began a multi-phase hydrologic investigation in 2004 to characterize the hydrologic system supporting the Pinelands aquatic and wetland communities.

Three Pinelands drainage basins - Albertson Brook, McDonalds Branch and Morses Mill Stream-were selected for a detailed hydrologic assessment to provide the information needed to develop a ground-water flow model that can be used to predict hydrologic responses to increased groundwater withdrawals. The first phase of this assessment consists of a comprehensive hydrogeologic investigation of each study area. The major objectives of this hydrogeologic investigation are to (1) compile available hydrogeologic data (2) conduct additional borehole and surface geophysical surveys and tests to measure aquifer hydraulic properties, (3) characterize the hydrogeologic framework, and (4) develop a hydrogeologic framework model of each study area that will be used in developing ground-water flow models for those areas.

\section{Purpose and Scope}

This report describes the methods used in, and results of, the hydrogeologic investigations conducted in and near the three study areas in the New Jersey Pinelands. The report documents the data-collection phase of the study, which included compiling historical information on surficial geology, stratigraphy, and aquifer and confining-unit characteristics; drilling 21 wells; conducting surface and borehole geophysical surveys; analyzing results of slug tests and well-performance tests to estimate hydraulic properties; and interpreting the hydrogeology of the localized Pinelands study areas. The interpretations illustrate localized differences in the hydrogeology in the vicinity of the three study areas that are typical of the Pinelands and they provide the information needed to develop and calibrate a ground-water flow model for each of the three study basins. The hydrogeologic framework is presented as structure-contour maps and maps that show the thickness of hydrogeologic layers, differences in sediment textures, and horizontal hydraulic conductivity $(\mathrm{K})$ data estimated from slug tests and well-performance tests.

\section{Description of Study Areas}

The three drainage basins were selected from a pool of 39 candidate basins because they represent a range of typical hydrologic, geologic, and ecological conditions and landscape features. Key hydrologic criteria for selection include aquifer thickness, drainage area, stream length, drainage density, past and current hydrologic monitoring and modeling, and current (2004) and potential ground-water withdrawals from the Kirkwood-Cohansey aquifer system. Major landscape features such as land use, soil type, and landscape cover also were considered. The Albertson Brook, McDonalds Branch, and Morses Mill Stream drainage basins were selected for the coordinated study of hydrology and wetland ecology (fig. 1). For the purpose of this report, each study area consists of the drainage basin surrounded by a buffer zone extending beyond the drainage-basin boundary. The larger area created by the buffer assures that a comprehensive hydrogeologic data set is available for each of the study areas. The extended hydrogeologic framework buffer boundaries also encompass the planned ground-water flow model domain.

The Albertson Brook study area encompasses $84.7 \mathrm{mi}^{2}$ consisting of a large part of the Albertson Brook drainage basin $\left(20.18 \mathrm{mi}^{2}\right)$ and the surrounding buffer zone. The Albertson Brook study area falls predominantly within Camden County with its eastern-most part extending into Atlantic County (fig. 1). The study area is bordered to the southwest by the Gloucester County line and is situated south of the Camden-Burlington County line. The dominant forested cover in the study area consists of mixed pine and oak forests in the uplands and hardwood and cedar swamps flanking the lowlands. Agricultural land is common throughout the basin but is nearly continuous south of the Albertson Brook. Residential development is most dense in the northern part of the basin in Camden County and along the highway corridors. Lightly developed residential areas are present in the lower part of the basin, which is largely agricultural or forested.

The McDonalds Branch study area is located in a minimally developed area in Burlington County, New Jersey (fig. 1). The basin is small $\left(5.52 \mathrm{mi}^{2}\right)$ and forested, containing a mix of pine and oak forests that surround hardwood and cedar swamps (Johnsson and Barringer, 1993). A small commercial cranberry bog surrounds McDonalds Branch in the lower part of the study area. Also in the lower part of the basin are lightly developed residential areas and a small recreational lake. The McDonalds Branch study area encompasses $28.08 \mathrm{mi}^{2}$.

The Morses Mill Stream basin is relatively small (8.35 $\mathrm{mi}^{2}$ ), and the study area totals $35.28 \mathrm{mi}^{2}$. The Morses Mill Stream study area is located in Atlantic County (fig. 1). In the eastern part of the study area, parts of the buffer zone and drainage basin are situated outside of the New Jersey Pinelands area boundary.

Developed and agricultural land are prominent features of the Albertson Brook and Morses Mill Stream study areas, and several production and irrigation wells, screened in the Kirkwood-Cohansey aquifer system, are within each basin. 


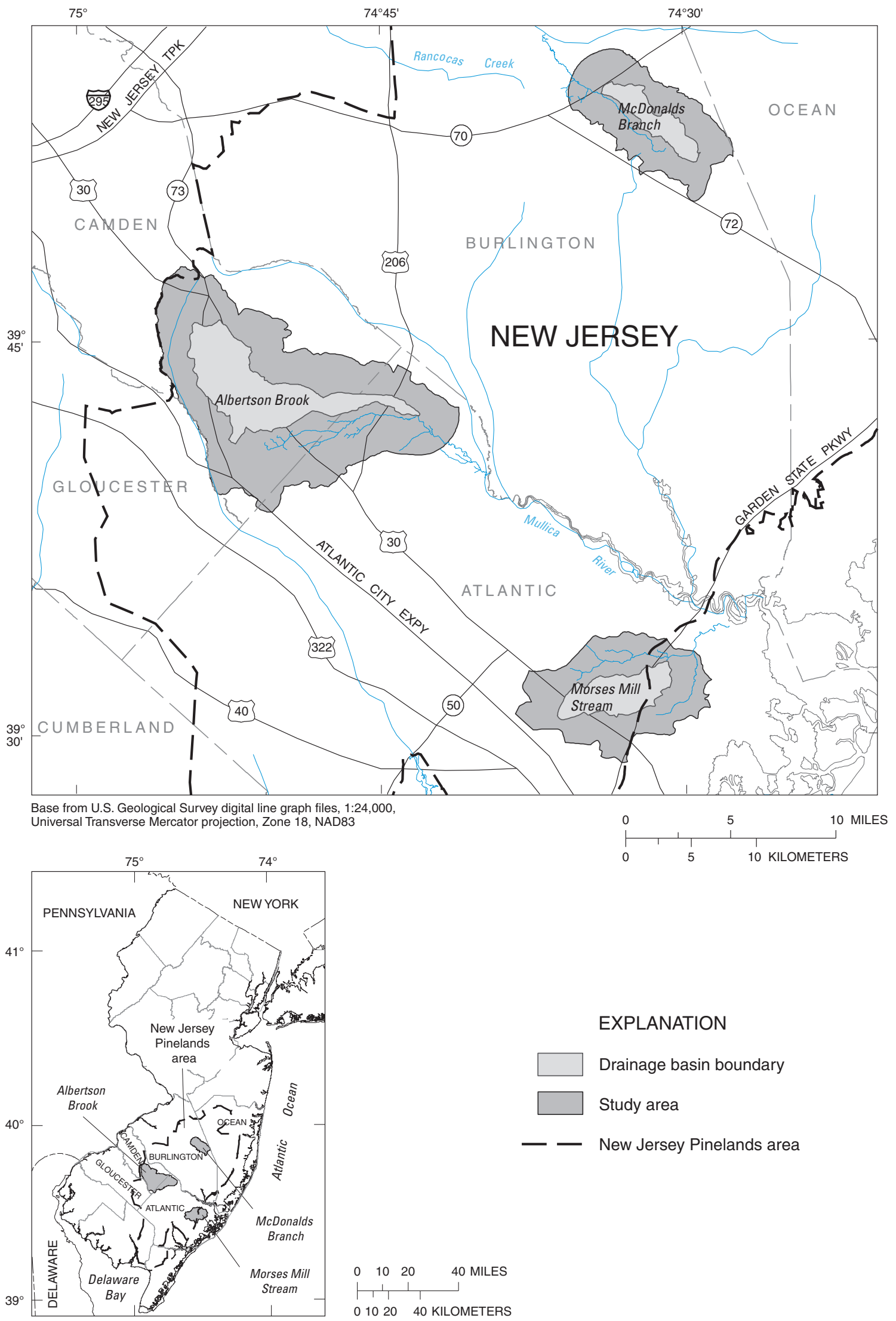

Figure 1. Location of the Pinelands study areas, Atlantic, Burlington, and Camden Counties, New Jersey. 
All study areas contain wetlands, with varying vegetative cover and soil conditions that typically have ground-water levels ranging from 0 to 12 in. below land surface during the growing season (U.S. Department of Agriculture, Natural Resources Conservation Service (NRCS), 2000).

\section{Hydrogeologic Setting}

The three study areas are underlain by the sediments of the Kirkwood-Cohansey aquifer system in the central and southern Coastal Plain of New Jersey. The KirkwoodCohansey aquifer system is the upper-most hydrogeologic unit of a wedge-shaped sequence of Coastal Plain sediments that lie on the pre-Cretaceous bedrock (Zapecza, 1989) (table 1). The Coastal Plain sediments are composed of sand and gravel aquifers separated by silt and clay confining layers that thicken and dip from the western limit of the Coastal Plain at the Fall Line to the southeast, reaching a thickness of more than 6,500 ft at Cape May, New Jersey (Gill and Farlekas, 1976). The Kirkwood-Cohansey aquifer system extends from the updip limit of the Kirkwood Formation to the Atlantic coast (fig. 2). The aquifer system is generally considered to be an unconfined (water-table) aquifer, although locally extensive clay layers can exist that can cause perched or semi-confined conditions (Zapecza, 1989, p. B19).

The Kirkwood-Cohansey aquifer system is principally composed of sands, silts, and clays of the Miocene age Kirkwood Formation and gravels, sands, and clays of the Cohansey Sand, also of Miocene age. Depending on location, the Miocene age Bridgeton Formation and (or) Pleistocene age and Holocene age sediments overlie the aquifer system in the vicinity of the study areas. Where present, these surficial sediments are considered to be part of the KirkwoodCohansey aquifer system. The material that composes the Cohansey Sand typically is coarser grained than that of the underlying Kirkwood Formation, which grades to clay near its base (Zapecza, 1989). Carter (1978) described the Miocene Cohansey Sand as a sequence of regressive barrier and barrierprotected deposits ranging from surf zones to back bays and marshes, a depositional environment that contributes to the formation of discontinuous lenses of sand, silt, and clay.

The generalized hydrogeologic section shown in figure 2 illustrates the position of the Kirkwood-Cohansey aquifer system in relation to other Coastal Plain sediments. The position of the two regional basal surfaces of the Kirkwood-Cohansey aquifer system, as described by Zapecza, (1989, p. B-19) are shown in figure 2 . In the western part of the aquifer system, beneath the Albertson Brook and McDonalds Branch study areas, the base of the aquifer system is the basal clay bed in the lower part of Kirkwood Formation. About 8 mi west of the Morses Mill Stream study area, the basal clay described above dips below a thick diatomaceous clay, an extensive confining bed in the upper part of the Kirkwood Formation locally known as the Upper Kirkwood confining layer (Zapecza, 1989, p. B18-B19) (table 1; fig. 2). The diatomaceous clay is present locally and separates the Kirkwood Formation into upper and lower sands. From the updip extent of its subcrop, the diatomaceous clay dips and thickens toward the east to approximately $200 \mathrm{ft}$ (Zapecza, 1989, pl. 22, 23) in the vicinity of Morses Mill Stream study area, locally forming the basal clay confining layer of the Kirkwood-Cohansey aquifer system. The upper sands of the Kirkwood Formation remain hydraulically connected to the Cohansey Formation and retain the name Kirkwood-Cohansey aquifer system. The lower sand of the Kirkwood Formation that dips beneath the diatomaceous clay is locally referred to as the Atlantic City 800-foot sand (fig. 2).

\section{Previous Investigations}

The geology and hydrogeology of the Miocene Kirkwood Formation, Cohansey Sand, Bridgeton Formation, and overlying Quaternary sediments that compose the KirkwoodCohansey aquifer system have been discussed by numerous investigators. The depositional environment of the Cohansey Sand described by Carter (1978) and the surficial geology of the central and southern Coastal Plain described and mapped by Newell and others (2000) represent some of the most recent work that interprets the origin and distribution of these sediments. The geology and ground-water resources of various counties were studied previously including Burlington County (Rush, 1968), Camden County (Farlekas and others, 1976), Gloucester County (Hardt and Hilton, 1969), and Ocean County (Anderson and Appel, 1969). Barksdale and others (1958) discuss the Kirkwood Formation and the Cohansey Sand over a four-county area in the New Jersey Coastal Plain. These early investigators describe the Kirkwood Formation and the Cohansey Sand as separate geologic units but often indicate that they are hydraulically connected. In addition, the Cohansey Sand and the overlying younger sediments were recognized as forming a single hydrologic unit. Rhodehamel (1973) discusses the geology and hydrology of the Kirkwood Formation and Cohansey Sand in the vicinity of the Mullica River basin in Atlantic and Burlington Counties (fig.1) and describes the Cohansey Sand-upper Kirkwood Formation as a single aquifer. Zapecza (1989) describes the Kirkwood-Cohansey aquifer system as it applies to a multi-layer ground-water flow model of the New Jersey Coastal Plain. The soils of Burlington County are described by Markley (1971), and the geology and soils of the McDonalds Branch basin are described and summarized by Lord and others (1990) and Johnsson and Barringer (1993), respectively.

\section{Methods of Investigation}

The methods discussed in the following sections describe the work required to acquire and interpret data in order to generate a hydrogeologic framework for each study area. The hydrogeologic framework is intended to provide a structural 
Table 1. Geologic and hydrogeologic units in the New Jersey Coastal Plain in New Jersey.

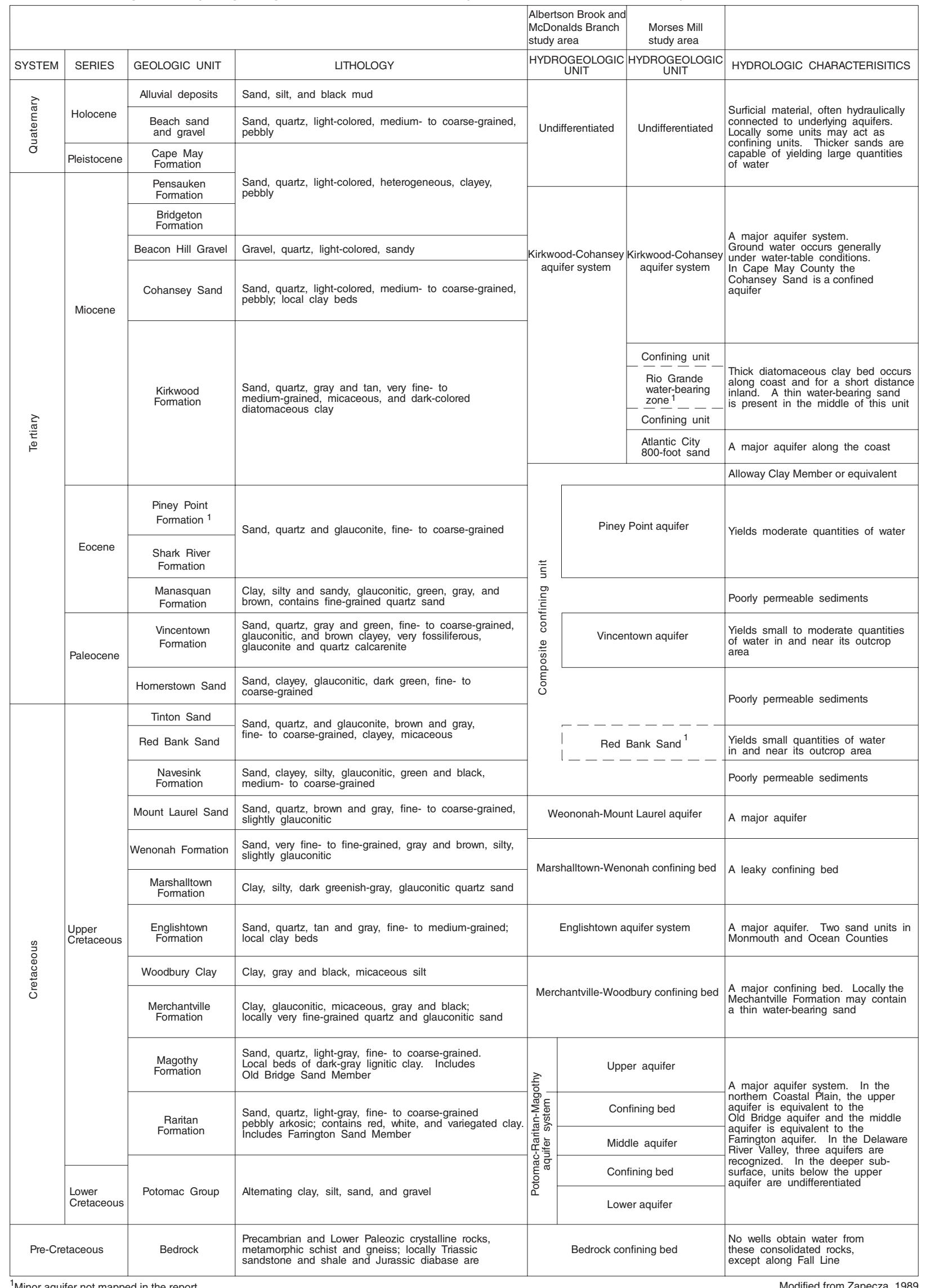


(a)

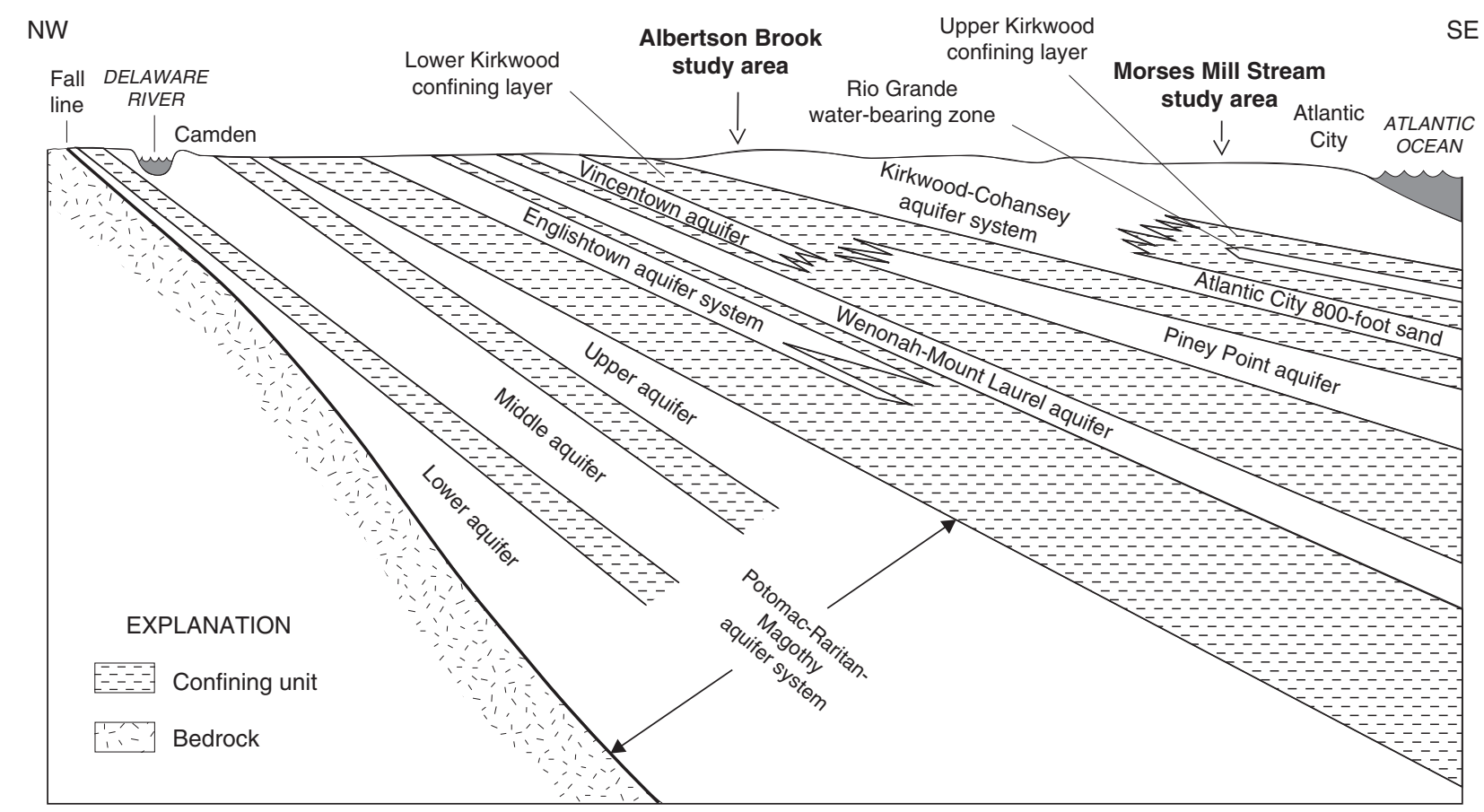

NOT TO SCALE

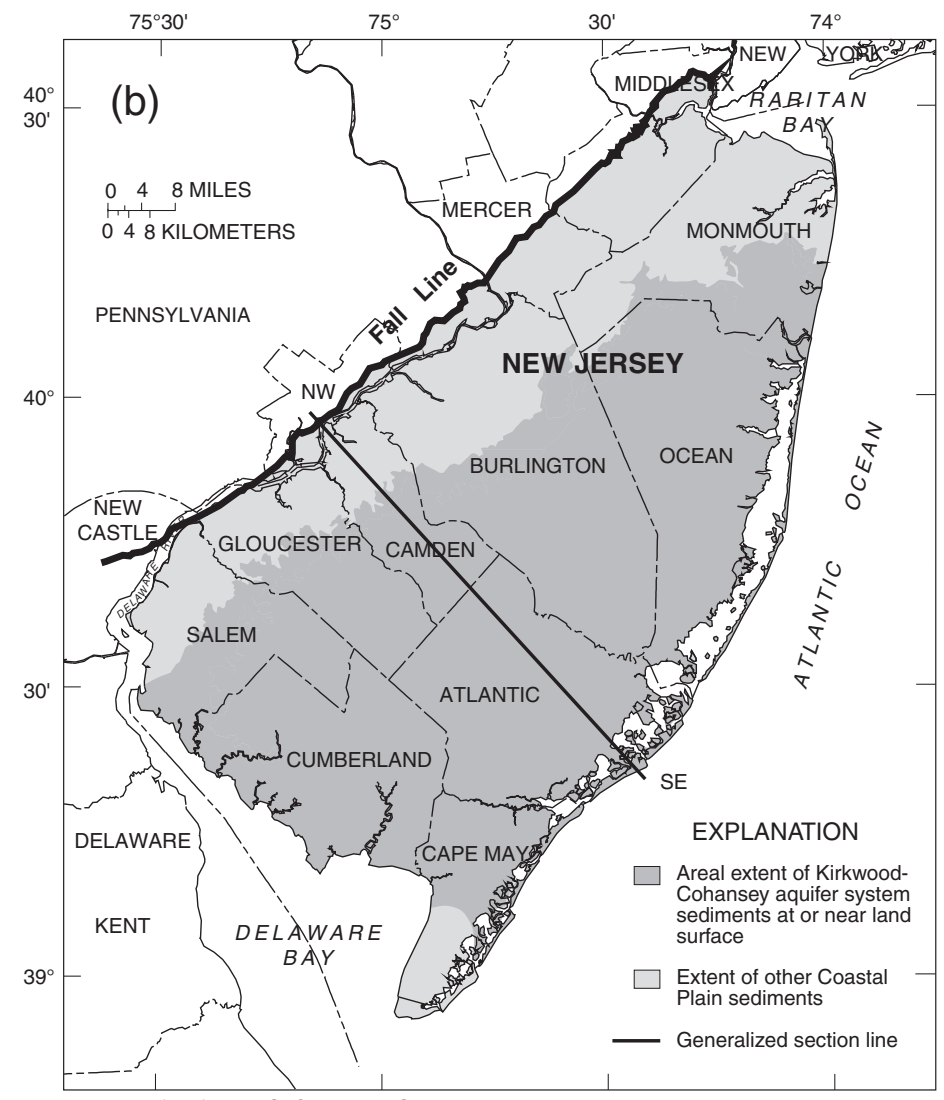

Base modified from U.S. Geological Survey digital

data, 1:100,000, 1983, Universal Transverse

Mercator projection, Zone 18

Figure 2. (a) Generalized hydrogeologic section through the New Jersey Coastal Plain (Modified from Zapecza and others, 1987) and (b) line of section. 
foundation for ground-water flow modeling of the three study areas. The framework investigations were extended outside the study-area boundaries to provide additional information used to determine the sub-regional structural characteristics of the aquifer system and, thereby, improve the definition of the framework model at the limits of the study areas.

The Kirkwood-Cohansey aquifer system has been described predominantly as a water-table aquifer, within which perched or semi-confined conditions can exist as a result of localized clays (Zapecza 1989). Thus, the framework interpretation ideally represents the structure of the aquifer system in a way that accounts for local lithologic differences, yet conforms to the sub-regional structural and depositional characteristics. The approach for developing the hydrogeologic framework model was to divide the aquifer system into aquifer layers and leaky confining layers that generally conform to the aquifer systems sub-regional structural and depositional characteristics and then describe the aquifer system hydraulic and physical properties associated with those layers.

The methods used to determine the aquifer system properties from well-performance and slug tests are described, including the details of the analytical methods used to calculate horizontal hydraulic conductivity $(\mathrm{K})$. These analyses provided ranges of $\mathrm{K}$ values that represent the aquifer system layers at locations where suitable wells were available. In addition, methods of estimating sediment textures within the hydrogeologic framework layers using geophysical and lithologic data are discussed in the following sections.

\section{Data Acquisition}

To characterize the hydrogeology of the KirkwoodCohansey aquifer system in each study area and to establish the ways this aquifer system interacts with water levels that affect wetlands and surface water, a thorough understanding of the continuity and effectiveness of the individual hydrogeologic layers involved in the processes of transmitting or isolating ground water is needed. Data-collection activities used to define the extent, thickness, and character of the principal hydrogeologic layers in each of the three study areas include

- A search of hydrogeologic literature;

- Evaluation of available geophysical and lithologic data;

- Geophysical logging of boreholes during well drilling;

- Examination of aquifer sediment samples and drill cuttings;

- Collection and analysis of surface geophysical data obtained using ground-penetrating radar (GPR);

- Performing slug tests;

- Collection of well-performance test data; and
- Compilation of a database of geophysical, lithologic, and hydraulic property data.

Data were obtained from multiple sources including the files of New Jersey Department of Environmental Protection (NJDEP), Pinelands Commission, the USGS, and the U. S. Environmental Protection Agency, and records of well drillers, well owners, and previous studies.

\section{Well-Numbering System}

Water-level monitoring wells installed during this investigation have a site name composed of the following codes: A two-letter drainage basin identifier

- MB (McDonalds Branch),

- $\mathrm{AB}$ (Albertson Brook),

- MM (Morses Mill Stream);

followed by a two-letter well type code

- OW (Basin cluster observation wells),

- UP (upland water-level wells);

and a well number followed by a letter suffix

- $\mathrm{S}$ (shallow),

- $\mathrm{M}$ (middle),

- D (deep).

The letter suffixes indicate the relative depth of an individual well within a cluster and are not intended to indicate that the well is screened in a specific hydrogeologic layer of the Kirkwood-Cohansey aquifer system.

Records of wells and boreholes included in this study (table 2 at end of report) were compiled and entered into the USGS Ground Water Site Inventory (GWSI) database (http:// waterdata.usgs.gov/nj/nwis/gwsi). These sites are identified by the USGS well number (UID), a two-digit county code number followed by a four-digit sequence number, and a unique site name composed of the UID followed by the local site identifier. The county code numbers used in this report are 01 for Atlantic County, 05 for Burlington County, 07 for Camden County, 15 for Gloucester County, and 29 for Ocean County.

\section{Altitude Data}

All altitude data presented in this report are referenced to the North American Vertical Datum of 1988 (NAVD88). Altitudes below NAVD88 are preceded by a minus sign (-). Altitudes used in this study have been determined in four ways using differential leveling, from topographic maps, using a surveying altimeter, or from a digital elevation model. All land-surface altitudes were rounded to the nearest foot; the 
altitude values, the methods used to determine the altitudes, and the levels of accuracy are given in table 2 .

Altitude data determined at new wells by level or other surveying method, with an accuracy of $1.0 \mathrm{ft}$ or better, are considered highly accurate and rounded to the nearest foot. All other sites used for the hydrogeologic framework have associated altitude data that were previously manually interpolated from 10-ft interval contours on 7.5-minute topographic quadrangle maps; these are considered accurate to within $5 \mathrm{ft}$.

A digital version of the 7.5-minute quadrangle maps, referred to as the USGS 10-meter Digital Elevation Model (10-meter DEM) of New Jersey, is a digital cartographic/ geographic dataset of altitudes in xyz coordinates derived from contour lines and photogrammetric methods using USGS 7.5-minute topographic quadrangle maps. The 10-meter DEM uses the same source as the historical altitude data, which are manually derived from 7.5-minute quadrangle maps, but the 10-meter DEM also contains updated point data that provide refined altitude values. The 10-meter DEM is considered to be accurate to within $5 \mathrm{ft}$.

To ensure that the 10-meter DEM was reliable, its grid was contoured and examined for anomalous data. In some localized areas, the contouring revealed altitude errors in the 10-meter DEM, indicating that during the construction of the 10-meter DEM, incorrect values were assigned to unlabeled contours on the quadrangle maps in a few areas. The errors were corrected by comparing the contours with those on the 7.5-minute quadrangle maps. Where the contours were interpreted incorrectly, corrections were applied by cutting out the affected area and patching in the corrected grid values for that area.

The altitudes of pre-existing sites that were originally determined from 7.5-minute topographic quadrangle maps were compared electronically with the corrected 10-meter DEM. Where the original site-altitude data were found to be in error, altitudes were updated in the database with values from the 10-meter DEM. The sites with more accurate altitudes, such as those determined by leveling, were not changed. Thus, the altitude used for a site is always based on the most accurate information available.

\section{Drilling Methods}

A total of 21 wells were constructed during this phase of the study in support of both the framework and water-level investigations. In addition, 1 deep boring and 10 shallow borings were completed to obtain lithologic and geophysical data. Locations of wells and borings were selected to fill gaps in the existing stratigraphic and geophysical data, aquire data on hydraulic properties of the aquifer system, and provide for collection of water-level data for another phase of this study.

All 21 wells and the 1 deep boring (051597 MBTB-1) were drilled by constructing open mud-filled boreholes using standard hydraulic rotary drilling methods. The drilling mud was composed of potable water mixed with a bentonite-clay- based drilling fluid additive. To maintain an adequate flow of cuttings from the borehole and to stabilize the borehole wall, the drilling-mud viscosity was tailored to the conditions in the borehole. During drilling, the materials penetrated by the boreholes were described by USGS field staff on the basis of drilling characteristics interpreted by the well driller, visual examination of drill cuttings washed from the hole, and visual examination of 12 aquifer sediment samples collected with a 2-in.-diameter split spoon sampler at selected locations and depth intervals.

Sixteen of the new wells were installed in the three study areas to determine aquifer hydraulic properties and to serve as water-level monitoring sites. The wells were arranged in six, 3 -well nests, two nests per study area. At each of two locations, one existing shallow well was used as part of the 3-well nests. At the well nest locations, well screens were usually installed at three depth intervals representing the major waterbearing zones, which are distributed from the base of the Kirkwood-Cohansey aquifer system to the water table. Five additional wells were completed in the shallow part of the surfical aquifer in the upland areas in the McDonalds Branch basin by using the same methods and materials.

All monitoring wells were installed using hydraulic rotary drilling methods by a New Jersey Licensed well driller in accordance with New Jersey State regulations. Wells were constructed of 2-in.-diameter flush joint polyvinyl chloride (PVC) casings with 10-ft-long screens with 0.010-in. slots. All wells were finished above land surface and secured with a steel surface casing with a lockable cap. Pumping and surging methods were used to develop the wells after at least 24 hours had elapsed following well completion. Records of the wells installed are given in table 2 and the lithologic logs are provided (app. 1).

Geologic sediment samples were collected from a total of 10 shallow borings at various locations in the Albertson Brook and McDonalds Branch basins using Geoprobe ${ }^{\circledR}$ sedimentsampling equipment. Using these samples, the lithology penetrated by each boring was described and their lithologic logs are provided (app. 1). These data were used in the interpretation of the hydrogeologic framework and the GPR records presented in the following sections.

\section{Geophysical Methods}

Borehole geophysical logs collected in seven of the deep wells or boreholes drilled for this study and more than $27 \mathrm{mi}$ of GPR line were used to obtain information on the subsurface lithology. Interpretations of the data on Coastal Plain sediments acquired using these methods require a working knowledge of the local geology and hydrology, and an understanding of the application and limitation of the methods used. Samples of geologic materials also were collected, examined, and compared with geophysical logs during drilling, and these data combined with historical drilling logs from locations with geophysical data provided the basis for extending the inter- 
pretation of the geophysical records. The following sections describe the methods used, technical information related to the acquisition and interpretation of the geophysical data, and the limitations of these methods.

\section{Borehole Geophysical Methods}

Borehole geophysical logs are commonly used in groundwater investigations to characterize the subsurface lithology and to correlate stratigraphy. Qualitative analysis of geophysical logs for determining lithology involves using a working knowledge of the local geology while comparing the response on logs with site-specific information, such as cores or other formation samples collected during drilling (Keys, 1987).

Geophysical logs (natural gamma, caliper, and various electric logs including spontaneous potential (VSP), singlepoint resistance (spr), and normal resistivity logs of 8-, 16-, 32-, and 64-in. electrode spacing), lithologic logs, and observations of drilling characteristics were made at six new wells and one new borehole within the three study basins (app.1). All of the logs were collected in open, mud-filled boreholes to depths ranging from about $182 \mathrm{ft}$ to $250 \mathrm{ft}$, which is generally at or below the top of the basal clays of the Kirkwood-Cohansey aquifer system. The geophysical logs and lithologic data collected provided the information required for interpretation of the lithology at each of the three areas of study.

The geophysical logs were compared in the field with descriptions of the lithologic samples and with drilling characteristics obtained in a manner that assured, to the greatest extent possible, the collection of representative data. Geophysical log records are interpreted using knowledge of the local geology and an understanding of the responses of logs or of suites of logs to various lithologies. Natural gamma logs typically show higher radiation in clays than in sands and gravels. VSP logs tend to indicate a more negative electrical potential in sands and gravels than in clays, and spr logs usually indicate lower resistance in clays than in sands and gravels. Normal resistivity electric logs typically measure lower electrical resistivity in clays than in sands and gravels. Caliper logs simply measure the borehole diameter. Suites of geophysical logs where large variations in borehole diameter were identified were analyzed by considering the effects of variations in diameter on the response of geophysical logs collected in that suite.

The data obtained from the geophysical logs were used to develop a comprehensive interpretation of the lithology at each well or borehole to guide the selection of screened intervals during well construction and provide the basis for interpreting lithology from other geophysical logs within the geologic settings typical of each study area. These geophysical logs were used later to correlate important hydrogeologic layers throughout the study areas.

\section{Surface Geophysical Methods}

GPR is a surface geophysical method designed to investigate shallow earth materials using electromagnetic wave energy (GPR waves) to acquire information about the subsurface. GPR surveys were conducted within the McDonalds Branch, Alberston Brook, and Morses Mill Stream basins to identify the presence, depth, and extent of the first subsurface clay layer that might impede the flow of ground water to or from the streams. The GPR surveys traversed accessible areas, along sand roads and trails.

The survey was conducted using a MALÅ GeoScience RAMAC GPR system equipped with $100 \mathrm{MHz}$ (megahertz) antenna. The antenna, distance measuring wheel, control unit, and the computer used for data acquisition and recording are attached to a sled pulled by the equipment operator. A total of $27 \mathrm{mi}$ of GPR line were surveyed within the three study areas. The data were processed using the MALÅ Geoscience RAMAC GroundVision proprietary software. The GPR radargram, the image generated from the measured GPR data (MALÅ Geoscience, 2003), displays a nearly continuous image representing the subsurface material beneath the GPR line. The radargram is an arithmetic graph of distance over the ground and the travel time of the reflected electromagnetic waves as they are affected by spatial changes in the conductivity-associated lithologic variability as the equipment is moved along the GPR line. The depth of penetration of GPR waves in relatively low conductivity material, such as sand, is typically less than $80 \mathrm{ft}$ using a $100 \mathrm{MHz}$ antenna. Highly conductive materials such as clay will attenuate the GPR waves, such that no electromagnetic energy is reflected from below the top of the first clay. As such, shallow clays mask all other geologic features that may lie beneath.

The depth to the top of a conductive layer, such as clay, is determined by recording the travel time of a reflected wave at a representative velocity. The velocity of electromagnetic wave energy in aquifer sediments was estimated by dividing the known depth of a reflector (based on lithology from borings) by the actual travel time of the electromagnetic wave as measured by the GPR system. The GroundVision software was used to verify the velocity estimate, and if needed, the velocity was adjusted so that the depth of a reflector observed on the radargram matched the depth of the reflector determined from the boring. Using these methods, the GPR wave velocity of saturated aquifer sediments in the three study areas was determined to be about $225 \mathrm{ft}$ per microsecond, a velocity typical of saturated sand (Peter Joesten, U.S. Geological Survey, written commun., 2004).

Based on available lithologic data in the vicinity of the GPR lines and the erosional and depositional features interpreted from the GPR records, the extensive conductive layers identified beneath the GPR lines were interpreted as clay. The tops of the clays were interpreted on the radargram at a depth and (or) travel time where electromagnetic wave reflections cease. Where continuous clays were identified on the GPR record, the location of the clay along the line of the survey was 
identified by its two endpoints and its approximate mid-point. At these GPR points, the depth to the top of the clay was determined from the GPR record, and the altitude of the GPR point locations was determined from the 10-meter DEM.

Each GPR point was assigned an identifier that consisted of a four-digit line number followed by a letter suffix. Interpretations of previous GPR surveys in the McDonalds Branch basin (Pierre Lacombe, U.S. Geological Survey, written commun., 1990) also identified the extent and depth of clays, and these interpretations were added to the recent GPR data set. Those points are identified by either a BR (Butterworth Road) or BP (Butler Place Road) suffix followed by a two-digit line identifier and a line sequence letter suffix. Sites used in the development of the hydrogeologic framework model are listed in table 2 .

A total of 273 GPR data points were interpreted in the three study areas, including 98 in the Albertson Brook, 96 in McDonalds Branch, and 79 in the Morses Mill study areas. These data were used to define the altitude and extent of the tops of the clays and to determine in which hydrogeologic model layer the individual clays were identified. In addition these data were used to describe the distribution and range of textures associated with the near-surface framework model layers.

The variability and density of the localized shallow clays revealed by the continuous GPR data, greatly exceeds the resolution needed for the sub-regional framework models, which are intended for use in ground-water flow models. Sixteen representative GPR data points were selected for use in developing the structure contour maps for the framework model layers; five in the Albertson Brook study area, seven in the McDonalds Branch study area, and four in the Morses Mill Stream study area.

\section{Interpretive Methods}

The following sections describe the methods used to compile a representative hydrogeologic data set, methods used to interpret and summarize the hydrogeologic and geophysical data, and the methods used to summarize the interpretations derived from these data. The interpreted data provided critical information about the hydrogeologic framework and the hydraulic and physical parameters needed for the groundwater flow models. All data derived by these methods are stored in the hydrogeologic database, available at the USGS New Jersey Water Science Center.

\section{Database Compilation}

Site information extracted from the Ground-Water Site Inventory (GWSI) database was used to populate a hydrogeologic framework database. The hydrogeologic database was prepared in MS Access. The hydrogeologic database is the repository for lithologic and geophysical data used for framework interpretation and includes the interpreted values that represent the tops of aquifers and leaky confining layers and characteristics of the hydrogeologic framework layers. The results of the slug test and well performance analysis are stored in a similar file.

Available well site information-geophysical, lithologic, and geologic data-were evaluated and compiled from multiple sources, including the NJDEP, Pinelands Commission, USGS, U.S. Environmental Protection Agency, well drillers, well owners, and previous studies. Data of acceptable quality were processed for analysis and entered into the hydrogeologic database.

The quality of the lithologic and geophysical data was evaluated to assure the data were acceptable and representative. The assessment of data quality is, in part, subjective, but knowledge and experience of the methods must be employed to assess data acceptability. For example, a lithologic log might be considered questionable when descriptions of sediments do not confirm the data from one or more good quality geophysical $\log (\mathrm{s})$ collected from the same location; an obviously poor resolution geophysical log might show no response in a zone where aquifer sediments described in the lithologic log transition abruptly from sand to a thick clay. Determining whether logs that contradict widely recognized geologic units, such as thick regional clay, are representative of the geology may require considerable scientific judgment.

Geophysical logs were preferred over lithologic logs because they generally provide reliable and unbiased information for interpreting and correlating lithology in Coastal Plain sediments. Although the descriptive logs of sediments from borings are useful in understanding lithology, the quality of available lithologic logs is highly variable, largely because descriptions of geologic sediments are often prepared by individuals representing a wide range of experience and interests, sometimes resulting in confusing descriptions that use vague or inconsistent terms to describe the observed sediment cuttings. Further complications include the difficulties in collecting representative samples of cuttings from hydraulic rotary drilled boreholes in unconsolidated sediments. Collection of samples from cuttings requires a thorough knowledge of the hydraulic rotary drilling process, but the ability to collect representative samples demands additional considerations for the travel time and stratification of cuttings in the mud-filled hole and the observed drilling characteristics.

New data collected during 2004-05 include geophysical and lithologic logs obtained from seven deep borings drilled in the study areas and lithologic logs of borings for five shallow wells in the McDonalds Branch study area. These data and the altitudes of the tops of clays interpreted from surface geophysical surveys were included in the hydrogeologic database.

\section{Development of the Hydrogeologic Framework}

A geologic data visualization software package called Rockworks ${ }^{\mathrm{TM}}$ was used to process and analyze hydrogeologic data and to provide mapping and interpretative tools for the construction of the hydrogeologic framework models. The 
data set includes a site identifier (UID), site location, altitude of land surface, lithologic descriptions from drilled boreholes, digital geophysical log data, and interpretations of depths to tops of shallow clays determined from GPR data.

Geophysical log suites, including natural gamma logs, electric, and caliper logs (predominantly natural-gamma $\operatorname{logs}$ ), were examined with other subsurface lithologic and geologic information to develop a conceptual model of the hydrogeologic framework for each Pinelands study area. The framework models are designed to support the three future study-area ground-water flow models. The approach used for preparing the framework models, discussed previously, divides the Kirkwood-Cohansey aquifer system into aquifer layers and leaky confining layers that reflect the aquifer systems subregional, structural and depositional characteristics and defines the range of variability of hydraulic and physical properties in those layers. The erosional and depositional environments of the Cohansey Sand, characterized by Carter (1978) and the Pleistocene age and younger surfical geologic sediments described by Newell and others (2000) provide valuable information that corroborates the apparent discontinuous nature of the lithology within the Cohansey Sand and the character and extent of the younger surficial geologic units. The framework models are intentionally based on the lithologic character of the sediments to a greater extent than the distribution of geologic formations because the framework model layers must support the ground-water flow models, which will represent the hydrogeologic system. The geologic environments leading to the deposition and erosion of the surficial sediments that has been described by previous investigators proved helpful in understanding and describing the variable lithologic character of the aquifer system.

Using the conceptual framework models, Rockworks ${ }^{\mathrm{TM}}$ was used to view and correlate geophysical and lithologic data in two-dimensional (2D) vertical sections for multiple sites with all geologic data presented in relation to a common datum. Initially, these sections were oriented along and normal to the recognized formation strike so that the regional dip of the formation could be considered in the interpretation of the framework layers. Using various sectional views, additional correlations were made between adjacent boreholes, the applicability of the conceptual framework model was confirmed, the structure tops of major hydrogeologic layers were finalized, and their depths were recorded in the hydrogeologic database. The altitudes of the tops of the hydrogeologic layers were calculated on the basis of land-surface altitude, rounded to the nearest foot.

\section{Mapping Hydrogeologic Framework Layers}

Structure contour maps of the tops of hydrogeologic layers, and thickness maps of these layers were prepared for each of the three study areas using the altitudes determined from geophysical and lithologic data. The Rockworks ${ }^{\mathrm{TM}}$ surface modeling software tool was used to create grid models of each hydrogeologic framework layer. The process involved prepar- ing structure contour maps of the tops of the hydrogeologic layers using the Kriging surface modeling algorithm, which also generated a comparable grid-based data set. For each study area, the boundary coordinates assigned to the modeled hydrogeologic grid layers were located outside the buffer zone (beyond the study area boundary), which allowed the use of all available hydrogeologic data in the immediate area surrounding the study area. These data, although sparse, improved the position of the structure contours at the study area boundary by forcing the edge effects that are commonly associated with limited, sparsely spaced data, to the fringes of the area of investigation. The farther outside the study area boundary the contours are, the more they tend to be of lower accuracy and, thus for illustrative purposes, all contours were clipped to the study area boundaries.

Given that the hydrogeologic layers lay one upon another, the bottom of a layer is the same as the top of the underlying layer. Thus, the thickness of each hydrogeologic layer was determined by calculating the difference in altitude between the modeled top of a layer and the top of the subjacent layer. The results of these calculations generated a thickness grid for each layer, and those grids were used to prepare structure thickness contours using Environmental Systems Research Institute, Inc., (ESRI) ArcGIS Spatial Analyst.

The extent of a layer is defined by the zero thickness contour generated from the grids. Areas where a layer crops out were identified as that area between its zero thickness contour and the position of the zero thickness contour of the overlying layer. All data used to prepare the structure contours are shown on the maps presented in appendixes 2 through 4 .

In some areas, the results of the contouring process indicated either considerable stratigraphic variability and (or) possible questionable geophysical and lithological data or interpretations. In these cases, data were re-examined with Rockworks ${ }^{\mathrm{TM}}$ using the previously described interpretative process, hydrogeologic section views were examined to identify the cause of the observed variations, and interpretations were adjusted where needed. In a few cases, data determined to be of poor quality were removed from the data set. Because of the known stratigraphic variability of the KirkwoodCohansey aquifer system and the scarcity of data in some areas where the data showed consistency with the depositional environments described by Carter (1978) and (or) the surfical sediments described by Newell and others (2000), variability in the data was accepted as indicative of the degree of geologic variability within the aquifer system.

\section{Hydrogeologic Sections}

Hydrogeologic sections were prepared for each study area from the final three-dimensional hydrogeologic framework model of each study area, which was created in Rockworks ${ }^{\mathrm{TM}}$ by stacking all of the layer grids. The sections illustrate four cross-sectional views for each study area, tracing point to point through interpreted data points that are located on the sections by a dashed vertical line. The 10-meter DEM 
was used to depict variations in the altitude of the land surface along the line of section. Gamma logs are shown on the sections where digital logs were available.

\section{Determination of Aquifer System Properties}

The process of constructing the hydrogeologic framework revealed considerable spatial variability in the lithologic character and, therefore, the hydraulic properties of aquifers and leaky confining layers within the Kirkwood-Cohansey aquifer system. The observed local variability of sediment textures that makeup the prominent hydrogeologic layers, although consistent with the depositional history of the aquifer system leaves uncertainty as to the distribution and ranges of the hydraulic properties within the aquifer system.

Developing an understanding of the spatial variability of hydraulic properties in the hydrogeologic layers provides a means of estimating their ability to transmit ground water. To examine the variability of hydraulic properties in the aquifer system, estimates of horizontal hydraulic conductivity $(\mathrm{K})$ were made by analyzing results from well-performance tests. Hydraulic conductivity describes the rate at which ground water will move through porous media in a unit time at a unit hydraulic gradient through a cross-sectional area measured at right angles to the direction of ground-water flow (Lohman, 1972). Slug tests were performed to determine K at the location of 16 monitoring wells. In addition, short-term wellperformance test data from 136 wells in the three study areas were analyzed to estimate $\mathrm{K}$. These methods are described in the following sections.

In addition to the $\mathrm{K}$ values estimated from the two types of well tests, sediment textures reported on lithologic logs and interpreted from geophysical data for each hydrogeologic layer represent the distribution and range of textures in these layers and, therefore, the variability of aquifer system properties. The approach used to interpret these data is described in "Estimation of Spatial Variability of Aquifer System Properties".

\section{Slug-Test Methods}

Slug tests were performed on 16 new wells by using either the air slug (Greene and Shapiro, 1995) or solid slug displacement methods. Air slugs were used for 14 wells where the screen was sufficiently submerged to allow air pressure to displace enough water to produce a reliable test without the risk of the air escaping through the screened interval. The air pressure was used to displace a proportional column of water from the well. Typically, the headspace in the well above the water was pressurized to about 5 to $7 \mathrm{lb} / \mathrm{in}^{2}(11.5-16.2 \mathrm{ft}$ of water). The pressure head was allowed to stabilize to assure there were no air leaks in the slug testing apparatus or well casing. Once the pressure had stabilized, the test was started by instantly releasing the pressure in the well to the atmosphere and simultaneously starting to record the water-level changes. Water-levels were recorded until they had stabilized at or near the initial level prior to pressurization, at which time the test was complete. At least two tests were run on each well.

The air slug method could not be used to create displacement in 4 of the 16 wells because the water table was too close to the screened interval. For these wells, a solid slug was used to displace an equivalent column of water from the well. At least two tests were run on each of these wells. The first of these, a falling head test, was run by quickly inserting the slug to a fixed depth and, at that instant, the test and the water-level recording was begun. Once the water level had fallen and stabilized at the initial level, the test was complete. Next, a rising head test was started by instantly removing the slug and starting the water-level recording. The rising water level was recorded until it had recovered to the initial level.

Water levels before/during/after the slug tests were recorded using a submersible data logger equipped with a pressure transducer. The data loggers were set to record water levels in log time, beginning with a time interval of threetenths of a second. The water-level records were examined in the field for quality assurance and to determine whether the test was suitable for analysis.

\section{Slug-Test Analysis}

Water-level responses from slug tests were plotted in relation to time to determine characteristics needed to calculate $\mathrm{K}$. The start time of the test and the initial static water level were identified from these plots. Typically, the start of the test was considered to be the time of the maximum displacement from the static water level. Time series data prior to initial displacement were removed from the record, and the time data were adjusted by subtracting the new start time from the remaining time data. In some cases the fully recovered water level at the end of the slug test deviated from the initial static water-level measurement by $\pm 0.02 \mathrm{ft}$. In these cases, the final water level was selected as the initial static water level when carrying out the slug test analysis.

The initial water displacement for air slug tests was defined as the maximum displacement from the static water level. In the case of solid slug displacement tests, early-time noise or oscillations were assumed to be caused by surging induced by rapid insertion or removal of the solid slug and not by the aquifer properties. The maximum displacement, in this case, was not considered to be the initial displacement from the static water level, but instead the initial displacement was defined as the onset of a smooth recovery.

Saturated aquifer thickness is a required parameter for each of the methods used for analysis. The total thickness of a layer was determined from the final interpreted framework thickness at each slug test well location. For the deep wells in a confined or semi-confined aquifer layer, where the layer is fully saturated, saturated thickness is equal to the total thickness of the aquifer layer. For shallow unconfined wells, the framework layer may be only partially saturated. In these cases, the thickness of the saturated part of the aquifer layer was used in the analysis. 
Hydraulic conductivity for each well tested was determined by analyzing the water-level responses from slug tests. Data from tests at the 16 new wells were analyzed using two analytical methods in the AQTESOLV ${ }^{\mathrm{TM}}$ analytical software package, which contains several analytical solutions for slugtest analysis. Both methods involve the graphical matching of theoretical type curves to plots of the water-level response in relation to time. The method of Springer and Gelhar (1991), which is well suited for unconfined formations with highly transmissive zones prone to inertial oscillations, was effective in analyzing the slug test data from four wells screened in unconfined aquifer layers. The method of Butler (1998), which is also effective for analyzing test results for wells in highly transmissive zones, was used to analyze data from 12 wells screened in confined or semi-confined aquifers. Both test methods are appropriate for fully or partially penetrating wells.

In both the Springer-Gelhar (1991) and Butler (1998) slug-test analytical methods, the aquifer is assumed to be infinite in areal extent, homogeneous, isotropic, and of uniform thickness; the potentiometric surface of the aquifer is initially horizontal, and flow is steady. The air or solid slug equivalent column of water is injected or discharged from the well instantaneously. Horizontal hydraulic conductivities calculated using these methods can be assumed to represent the aquifer only in the vicinity of the screened interval. The Butler method is a modification of the Hvorslev method (1951). The SpringerGelhar method is a modification of the method of Bouwer and Rice (1976); modifications include treatment for oscillatory responses. A summary of the test details and the estimated horizontal hydraulic conductivities are given in table 3 .

\section{Well-Performance Tests}

Water-transmitting properties of aquifers can be estimated from well-performance tests, such as tests commonly conducted to determine the specific capacity of a well. Specific capacity is a measure of the productivity of a well and is calculated as the pumping rate divided by the resulting drawdown after the well is pumped at the same rate for some period of time (Freeze and Cherry, 1979). Reported well-performance data for 136 wells in the three study areas were retreived from the USGS GWSI database for the purpose of estimating values of hydraulic conductivity.

Values of aquifer transmissivity can be estimated from specific capacity data if the duration of the withdrawal and the well radius are known, assuming that effects of partial penetration, well loss, hydrologic boundaries, and well development are all negligible. Walton (1970, p. 315) presents the following equation to estimate aquifer transmissivity from specific capacity data:

$$
\frac{Q}{s}=\frac{T}{264 \log \left[\frac{T t}{2693 r_{w}^{2} S}\right]-65.5},
$$

$$
\text { where } \begin{aligned}
\frac{Q}{S} & =\text { specific capacity }[(\text { gallon/minute)/feet }] \\
Q & =\text { discharge (gallon/minute) } \\
S & =\text { drawdown (feet) } \\
T & =\text { transmissivity }[\text { (gallon/day)/feet }] \\
S & =\text { storage coefficient (dimensionless) } \\
r w & =\text { well radius (feet), and } \\
t & =\text { time after pumping started (minutes). }
\end{aligned}
$$

Hydraulic conductivity can then be estimated from the transmissivity value as:

$$
K=T / b,
$$

where

$$
\begin{aligned}
K= & \text { estimated hydraulic conductivity (feet/ } \\
& \text { day) } \\
T= & \text { aquifer transmissivity (feet }{ }^{2} / \text { day), and } \\
b \quad= & \text { aquifer thickness (feet) }
\end{aligned}
$$

In addition to specific capacity data for the 136 wells, reported pumping duration, depths to the top and bottom of open intervals, and well radius were used in applying equations (1) and (2). The practical application of equation (1) requires an assumption regarding the storage coefficient. A storage coefficient of 0.15 was assumed. This value is consistent with the range of specific yield values for unconfined aquifers presented by Freeze and Cherry (1979) and with that for the Kirkwood-Cohansey aquifer system presented by Rhodehamel (1973). Other important assumptions used in the calculation are that the effects of partial penetration, well loss, and hydrologic boundaries, as well as the effects of well development on the effective well radius are all negligible. The effects of partial penetration are uncertain because the partial volume of the aquifer that is stressed during these reported tests is unknown. This is because the reported pumping rate and (or) duration may be insufficient to stress the full thickness of the aquifer. An implicit assumption of the method selected for the application of equation (2) is that the thickness of the aquifer strata (b) stressed during the test is equivalent to the length of the screened interval of the well. The relations between the input variables and the estimated transmissivity values also were examined, and a determination was made that the estimated transmissivity values were only slightly affected by the pumping rate, duration, or total pumped volume.

The effects of well loss and the presence of impermeable boundaries (such as production zone pinch-out) could result in a tendency to underestimate transmissivity. The effects of the presence of recharge boundaries (such as nearby streams) and well development could result in a tendency to overestimate transmissivity. The net effect of these uncertainties and assumptions could result in either an over- or underestimation of transmissivity at a particular site. Results obtained using equations (1) and (2) can provide some indication of the likely range of hydraulic conductivities of water-bearing strata and a general indication of the spatial distribution of hydraulic con- 


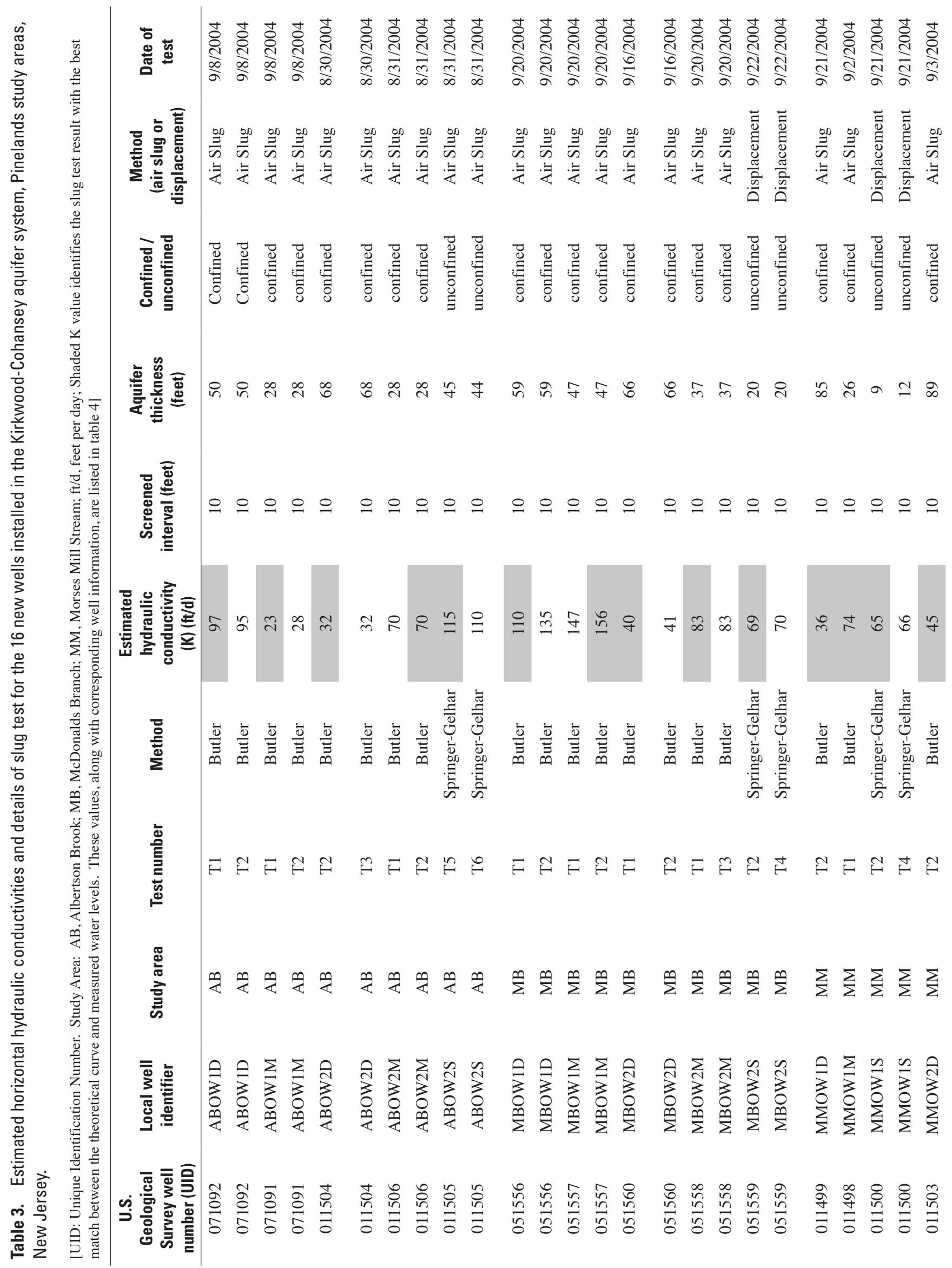




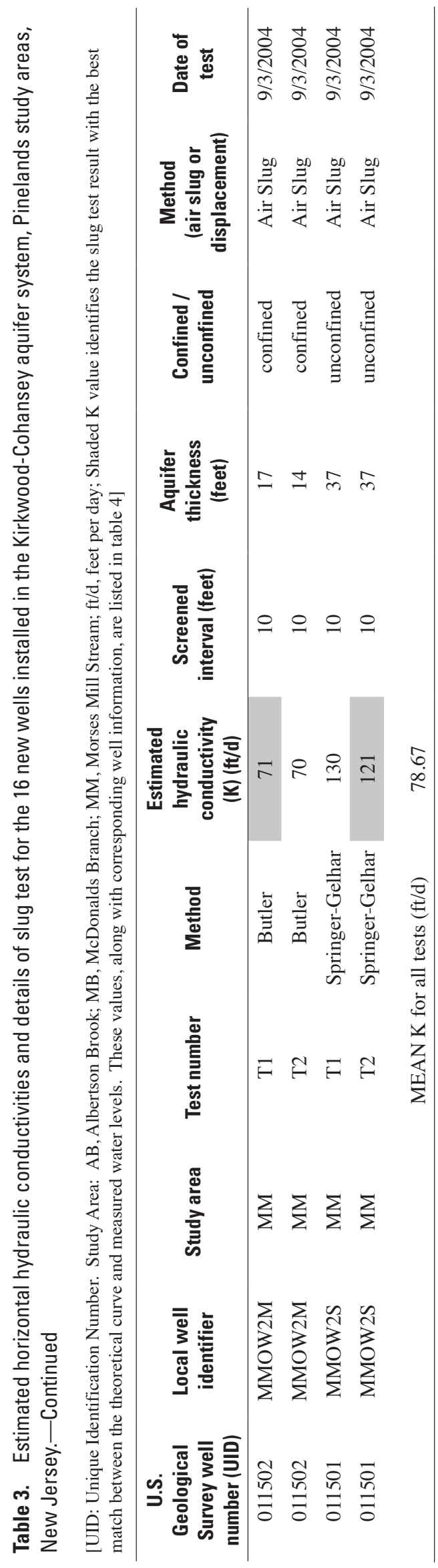


ductivity in the study areas. Horizontal hydraulic conductivities estimated using well-performance data are listed in table 4 (at end of report).

\section{Estimation of Spatial Variability of Aquifer System Properties}

The distribution and range of aquifer system properties within each hydrogeologic layer was estimated at a coarse scale by characterizing sediment textures on the basis of the range of grain sizes reported on lithologic logs and by estimating grain size from geophysical data. These data indicate that within the aquifers and the leaky confining layers, lithology can vary considerably. To illustrate this variability, sediment textures were categorized into five ranges of sand content using the approach described below.

A description of the spatial variability of aquifer system properties was limited to the estimation of sediment textures as a percentage of non-clay content ("sand content" or "percent sand"). Percent sand was described at locations and depth intervals that represent each of the framework layers penetrated by a borehole or well. This approach was limited because it did not allow for differentiating possible ranges of gravel or sand grain sizes and resulted in low percent sand values that simply indicate high clay content.

The percent sand values were estimated as the percentage of a framework model layer thickness that is attributable to the permeable sediment fraction, using the description from a lithologic log and (or) the interpretation of geophysical data at a specific location. Geophysical logs were interpreted using methods described previously, and lithologic logs (drillers or geologists logs) were evaluated in part by interpreting the written log and by relying on the knowledge of how lithologic logs compare with geophysical logs interpreted at other locations within the study area. Percent sand values also were estimated from GPR records, but these values are limited to representing only that thickness of permeable sediments between the top of the framework layer that overlies the interpreted clay and the top of the clay. In this case the actual clay thickness is unknown (see previous GPR discussion in "Geophysical Methods"); thus, the percent sand values may be underestimated. Where the GPR records indicate that a specific layer of the framework model layer contains no clay, percent sand values are correctly stated as mostly sand.

The estimated percent sand values of hydrogeologic layers were illustrated by preparing a data grid using the inverse distance statistical method in Rockworks ${ }^{\mathrm{Tw}}$. ESRI ArcGIS Spatial Analyst was then used to classify the sand content of the hydrogeologic layers into five categories, ranging from mostly sand (80 to 100 percent sand) to mostly clay (0 to 20 percent sand).

Although it is widely recognized that grain size distribution and hydraulic conductivity are related (Freeze and Cherry, 1979), attempts to correlate $K$ values from the results of slug-test analyses with the percent sand values were unsuc- cessful because textures were estimated at a coarse scale using lithologic logs and geophysical data. Grain size distribution from sieve analysis could have improved the correlation, but that approach was beyond the scope of this study. In addition the depth intervals commonly were not comparable because the textures represent the entire framework layer thickness, whereas the well-screen intervals were rarely equal to the thickness of the hydrogeologic layers at the well locations.

\section{Hydrogeologic Framework}

For each study area, the Kirkwood-Cohansey aquifer system, which Zapecza (1989) describes as a single hydrogeologic layer, was subdivided into seven layers characterized by their predominant grain size textures as aquifers or leaky confining layers. These layers were defined through spatial comparisons of the new geophysical and lithologic data (app.1) and similar available data for the vicinity of each study area. The hydrogeologic framework modeling process described in "Development of the Hydrogeologic Framework" produced three similar but distinctly separate framework models, each one unique to a particular study area. The models, one for each of the three study areas, are described and illustrated in the following sections.

Many hydrogeologic sections were used to the develop the framework models. Twelve sections (four for each study area) were generated to illustrate the framework layers. The sections trace from data point to data point along lines of section, slicing through their associated three-dimensional hydrogeologic framework model to show the relation of the modeled layers to each other and to the land surface. Where available, gamma logs were included to show the distribution of sediment textures and the extent of the sands and clays associated with the leaky confining layers.

As discussed previously, the base of the KirkwoodCohansey aquifer system for this study is generally represented by the two different regional basal surfaces described by Zapecza (1989). In the western part of the aquifer system, beneath the Albertson Brook and McDonalds Branch study areas, the base of the aquifer system is the extensive basal clay bed in the lower part of Kirkwood Formation. Although no attempt was made to correlate the basal clay layers between these two study areas, the similarity of altitude of the basal clays to the basal clay described by Zapecza (1989) indicates this basal layer is common to both study areas. Beneath the Morses Mill Stream study area, the base of the aquifer system described previously in the "Hydrogeologic Setting" section is the thick diatomaceous clay, a locally extensive confining bed in the upper part of the Kirkwood Formation.

On the basis of new geophysical data collected for this study, the top of the basal clays in some parts of the study areas are represented by a geologic contact that grades from coarse- to fine-grained sediments over as much as tens of 
ft. In these cases gamma and electric logs may represent the contact differently because of the composition of the geologic material. Electric logs were usually preferred over gamma logs because, generally, they represented the hydrologically significant top of the basal clay bed more accurately than the gamma logs. As a result of additional geophysical and lithological data collected during this study, some of these interpretations may differ from those of Zapecza (1989).

The deeper hydrogeologic framework layers tend to dip to the southeast and generally conform to the slope of the top of the basal clay in the Albertson Brook and McDonalds Branch study areas. The deeper layers appear to dip to the southeast and conform to the slope of the diatomaceous clay in the Morses Mill Stream study area. The dip of the overlying layers decreases slightly where the layers are closer to the land surface. The tops of the shallower layers generally follow the slope of the drainage basins, more than the deeper layers, reflecting a closer relation to the erosion-incised valleys forming those basins.

With the exception of the basal clay confining beds, the variable and discontinuous nature of clays within the Kirkwood-Cohansey aquifer system was apparent in the geophysical and lithologic records. Low permeability layers appear to be more closely spaced and the presence of discontinuous clays generally more common, in the upper part of the aquifer system, which is principally represented by the Cohansey Sand. The increased presence of clays in this part of the aquifer system is consistent with the depositional environment of the Cohansey Sand, a sequence of regressive barrier and barrier protected deposits that form discontinuous layers of sand, silt, and clay (Carter 1978). In many areas the Cohansey Sand is capped by the Bridgeton Formation, Pleistocene terraces, and (or) younger near-stream deposits. This study treats these surficial geologic sediments as a hydraulically connected part of the upper-most framework model layers that exist in those areas. The hydraulic properties of these surficial deposits were integrated into the framework analysis by considering their depositional environment described by Newell and others (2000) and Carter (1978) while characterizing variations in sediment textures observed in geophysical and lithologic records.

The tops of clays interpreted from GPR data recorded at selected locations illustrate the full linear extent or absence of clays lying beneath the GPR survey lines. Estimation of the depths to the tops of clays was limited by the presence of the first clay or the practical depth investigated by the equipment used, which was generally less than $80 \mathrm{ft}$. In areas where the first clay obscured all underlying sediments, no GPR data are available to define the presence or extent of the underlying clays. Altitudes of the clay tops determined from GPR data were compared with the framework model, and the hydrogeologic framework model layer within which the clays lie was determined. Although clays were commonly identified in the leaky confining layers, in all study areas, some clay layers were found to lie within the aquifer layers.
Although the Kirkwood-Cohansey aquifer system generally has been considered a water-table aquifer in most areas, localized clays within the aquifers and the relative effectiveness of the leaky confining layers may impede the flow of ground water in varying amounts, depending on the effectiveness of confinement and the duration and magnitude of the hydraulic stresses applied. The available data indicate considerable variation in sediment textures in the hydrogeologic layers; the lack of sufficient available data limits the extent to which these variations can be interpreted. Estimates of hydraulic conductivity derived from slug tests and wellperformance tests at previously installed wells (tables 3 and 4) and a general understanding of the distribution and range of textures throughout the thickness of the hydrogeologic layers provides additional information for understanding the spatial distribution of aquifer system properties within and among the modeled layers.

Site information for wells that were used to determine hydraulic conductivity are listed in table 2 by data type code: ST for wells with slug-test data, and WP for wells with wellperformance data. Slug tests were conducted in relatively low-yielding, small-diameter wells with short screen intervals (figs. 3-5); for these wells, K values represent point values for specific aquifer layers. Some wells used to estimate K from well-performance tests were of high capacity, have long screened intervals that penetrate leaky confining layer boundaries, and are open to multiple layers of the framework. In these cases, the $\mathrm{K}$ values represent multiple hydrogeologic framework model layers of the aquifer system. The hydrogeologic layers penetrated by the well screens are identified in table 4 . The mean hydraulic conductivity values determined from various well tests in the three study areas ranged from 84 to $130 \mathrm{ft} / \mathrm{d}$. The estimated $\mathrm{K}$ values from well tests are consistent with those reported by Rhodehamel (1973) for the Kirkwood-Cohansey aquifer system, which ranged from 90 to $130 \mathrm{ft} / \mathrm{d}$ in the general vicinity of the study areas. K values for the study areas are discussed in the following sections.

\section{Hydrogeology of Albertson Brook Study Area and Vicinity}

The base of the Kirkwood-Cohansey aquifer system in the vicinity of the Albertson Brook study area (fig. 2) is the regionally extensive basal clay bed in the lower part of the Kirkwood Formation (Zapecza, 1989). In this area, the Kirkwood-Cohansey aquifer system is composed of sand, gravel, and clay that typically grade to fine sand, silt, and clay near the base of the aquifer system, forming a gradational contact with the basal clay confining bed.

The Albertson Brook study area lies at the approximate southern limits of the Central Uplands described by Newell and others, (2000). From this area to the south, the upper delta plain deposits of the Miocene Bridgeton Formation overlie the Cohansey Sand with an unconformable contact. The Bridgeton Formation is generally a coarse-grained fluvial deposit, 


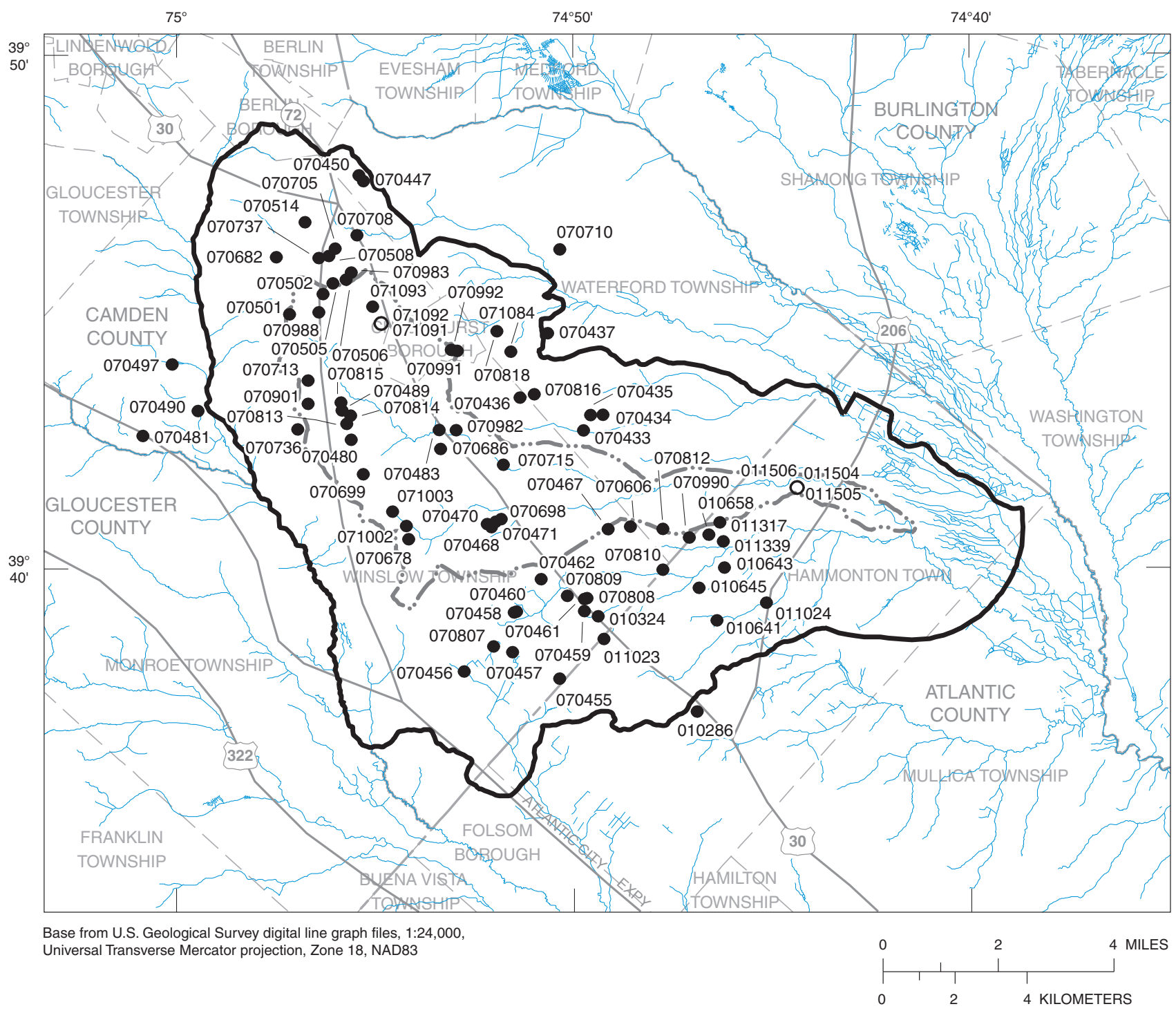

EXPLANATION

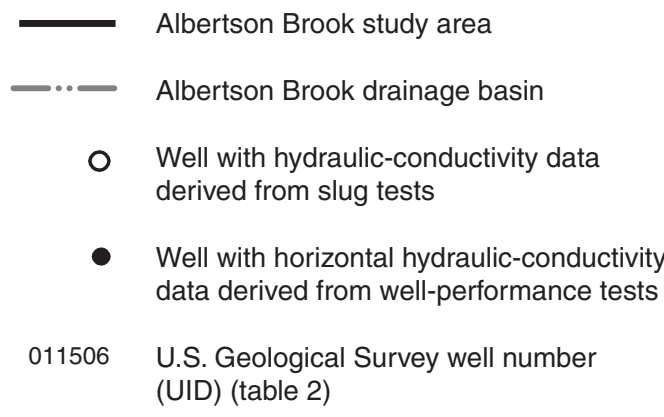

Figure 3. Location of wells with horizontal hydraulic-conductivity data, Albertson Brook study area and vicinity, New Jersey Pinelands. 


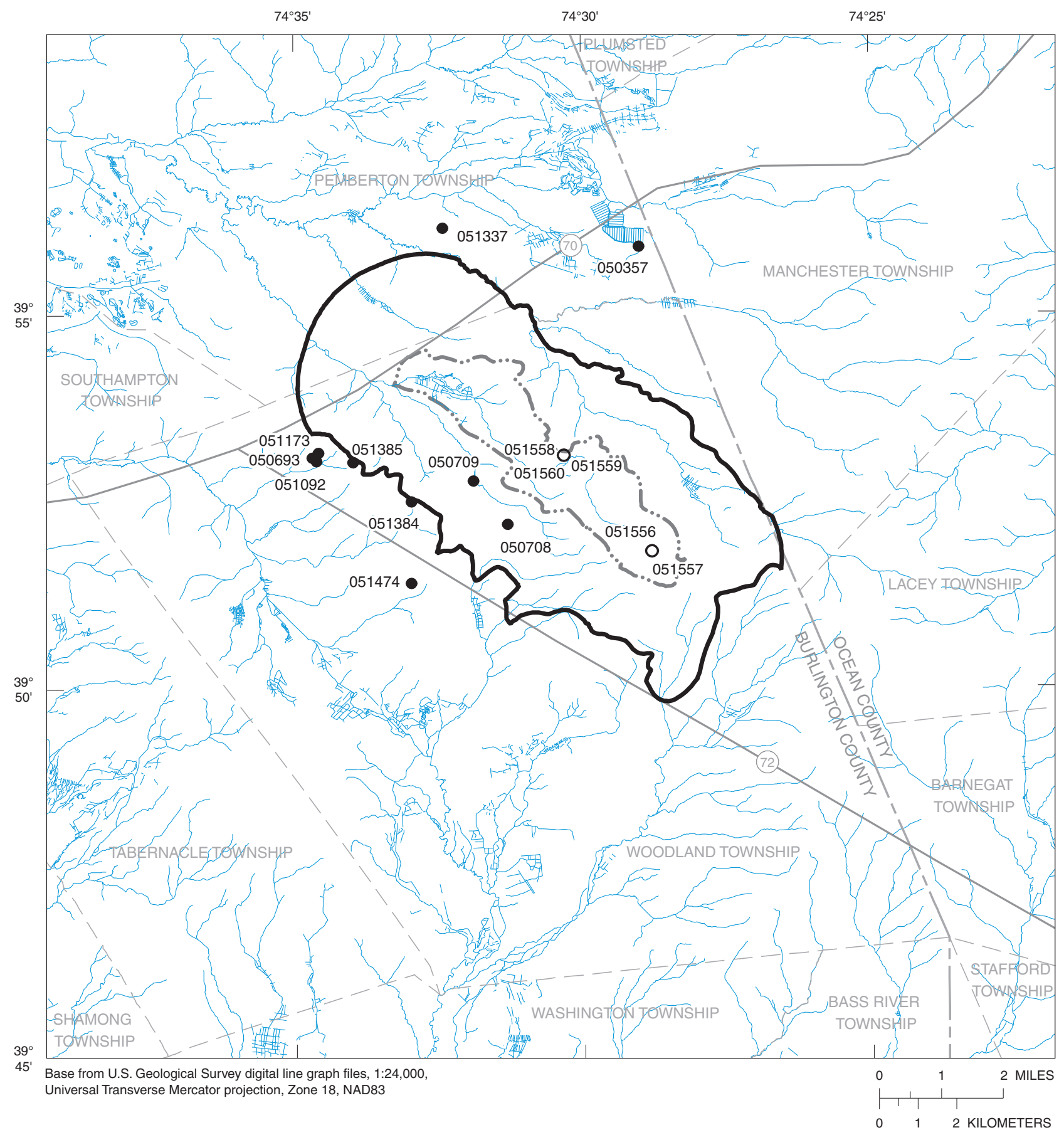

EXPLANATION

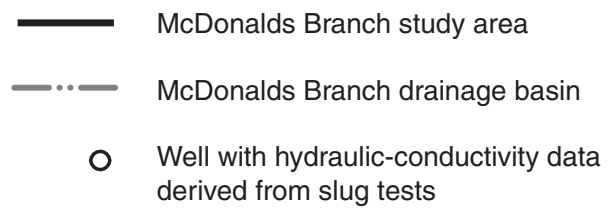

- Well with horizontal hydraulic-conductivity data derived from well-performance tests

011506 U.S. Geological Survey well number (UID) (table 2)

Figure 4. Location of wells with horizontal hydraulic-conductivity data, McDonalds Branch study area and vicinity, New Jersey Pinelands. 


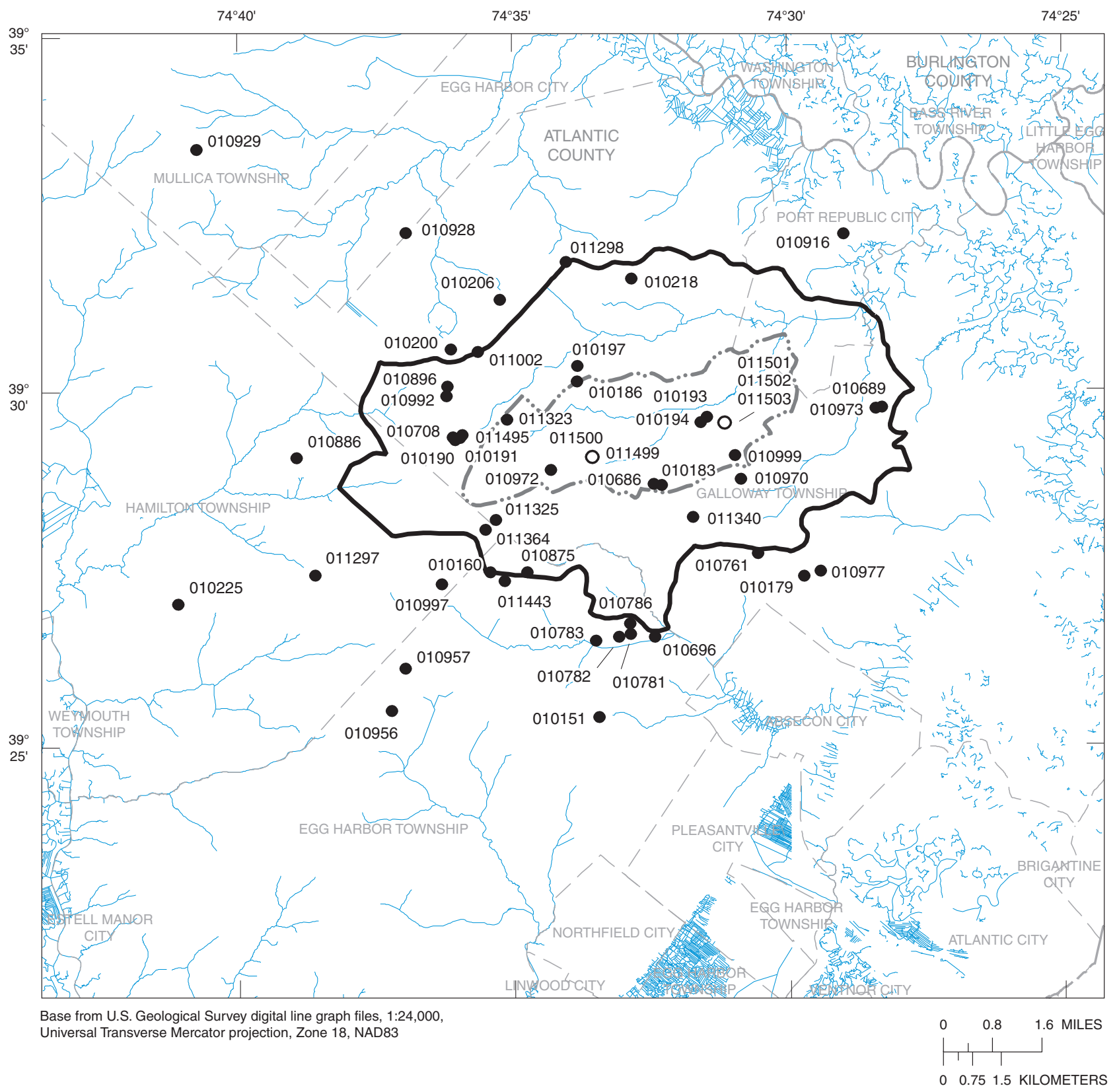

EXPLANATION

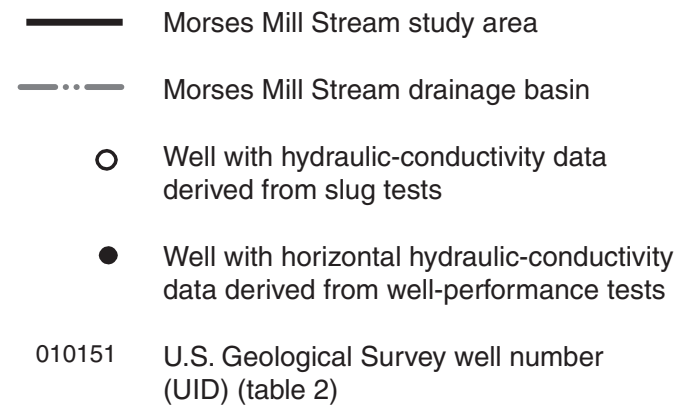

Figure 5. Location of wells with horizontal hydraulic-conductivity data, Morses Mill Stream study area and vicinity, New Jersey Pinelands. 
with numerous channel bars forming the higher topographic features within the study area. In the areas flanking the drainages, the Bridgeton Formation is absent where downcutting of stream valleys has exposed the Cohansey Sand. In these areas, Pleistocene to Holocene age deposits commonly are present near the streams and swamps. The shallowest framework layers consist of the surficial geologic sediments described by Newell and others (2000). Depending on location, the uppermost hydrogeologic layers may consist of highly permeable sediments of the Bridgeton Formation and (or) the sediments of the Cohansey Sand, which are capped locally with Pleistocene to Holocene age deposits.

The upper tributaries of the Albertson Brook basin drain from the upper delta plain deposits of the Bridgeton Formation northeast of the Egg Harbor River basin (not shown). In the lower part of the Albertson Brook basin, Pleistocene age terraces, and slope and valley deposits of the Central Uplands border the stream channel where the Albertson Brook drains to the Mullica River and Atlantic coast (Newell and others, 2000).

Soils in the Albertson Brook study area are generally well-drained sandy loams and loamy sands with a moderate to rapid permeability; permeability is reduced in areas of shallow water table, where hydric soils are present and where muck soils are common in the areas of streams and swamps (Markley, 1965).

The hydrogeologic framework of the Albertson Brook study area is represented by four aquifer layers separated by three leaky confining layers and a basal confining layer generally represented by the basal clay bed in the lower part of the Kirkwood Formation described by Zapecza (1989). The following list describes the hydrogeologic framework layers for the Albertson Brook study area and presents their identifiers.

\begin{tabular}{ll}
\hline Layer identifier & $\begin{array}{l}\text { Description of the hydrogeologic frame- } \\
\text { work of the Albertson Brook study area }\end{array}$ \\
\hline AB A-1 & Upper aquifer - upper layer \\
AB A-1C1 & Upper leaky confining layer \\
AB A-1B & Upper aquifer - lower layer \\
AB C-1 & Middle leaky confining layer \\
AB A-2 & Middle aquifer \\
AB C-2 & Lower leaky confining layer \\
AB A-3 & Lower aquifer \\
AB C-3 & Lower Kirkwood basal clay \\
\hline
\end{tabular}

The location of the 57 sites including wells and selected GPR data points used to describe the hydrogeologic framework for the Albertson Brook study area are shown in figure 6 . Detailed site information is provided in table 2 . The altitudes of the tops of the hydrogeologic layers in the Albertson Brook study area and vicinity are listed in table 5.
Four hydrogeologic sections (A-A', B-B', C-C', and D-D') were generated from geophysical and lithological data for selected well and borehole sites (table 2) in the Albertson Brook study area. The location of these sections are shown in figure 7. Two sections, A-A' and B-B', (figs. 8 and 9) trace from site to site, slicing through the framework model from the southeast and following the general orientation of the drainage basin and the direction of the regional dip of Coastal Plain sediments. The two other sections, C-C' and D-D', (figs. 10 and 11) cross the basin normal to the southeast trending sections. The distribution of fine-textured sediments illustrated by the gamma logs indicates the variable nature of the sands and clays associated with the framework layers.

Structure contours were prepared from the altitudes of the tops of seven of the hydrogeologic layers listed in table 5 using methods described previously. A contour map was not prepared for the top or the AB A-1 layer because, where the layer exists, it is the same as the land surface and is best described by the 10-meter DEM. Thickness maps were prepared for seven of the hydrogeologic layers, but none was prepared for the lower Kirkwood confining layer, AB C-3, because the thickness of this layer was not investigated during this study. (See Zapecza, 1989, pl. 23.) The distribution and range of textures estimated for the hydrogeologic layers are shown on the thickness maps. In addition, $\mathrm{K}$ values representing individual framework layers are shown on their respective thickness maps so that the distribution of $\mathrm{K}$ and the textures can be compared. $\mathrm{K}$ values estimated from well-performance tests (table 4) in the Albertson Brook basin ranged from $11 \mathrm{ft} /$ day to $608 \mathrm{ft} /$ day, and the average $\mathrm{K}$ was $130 \mathrm{ft} /$ day. The structure contour and thickness maps are presented in appendix 2-1 through 2-14.

The results of the GPR surveys in the Albertson Brook study area (fig. 12) confirm the variabilty of the altitude of the tops of clays near the Albertson Brook stream. In the areas investigated in the upper part of the basin, GPR records indicated relatively few places where coarse sediments in any one hydrogeologic layer are continuous down to the top of the AB C-1 leaky confining layer. In this area a continuous clay principally associated with the AB A-1C1 leaky confining layer was identified (fig. 12). The AB A-1 aquifer layer obscured all underlying sediments in a few areas, and the AB A-1C1 layer obscured the other layers below. GPR records also indicate the presence of erosional and depositional features in several areas where sloping bedding planes were revealed in the coarsegrained media, and (or) the tops of clays appear to be sloping, truncated, or absent. These conditions appear to be more common in the lower (eastern) part of the Albertson Brook basin where fewer clays were identified near Albertson Brook than in the upper part of the basin. Given the depositional history of the Cohansey Sand, it is also possible that some clays simply represent discontinuous lenses that are eroded to the slope of the drainage basin and may not be remnants of a single layer. For the purpose of the framework model, however, these clays are considered to represent one leaky confining layer of low permeability sediments. 


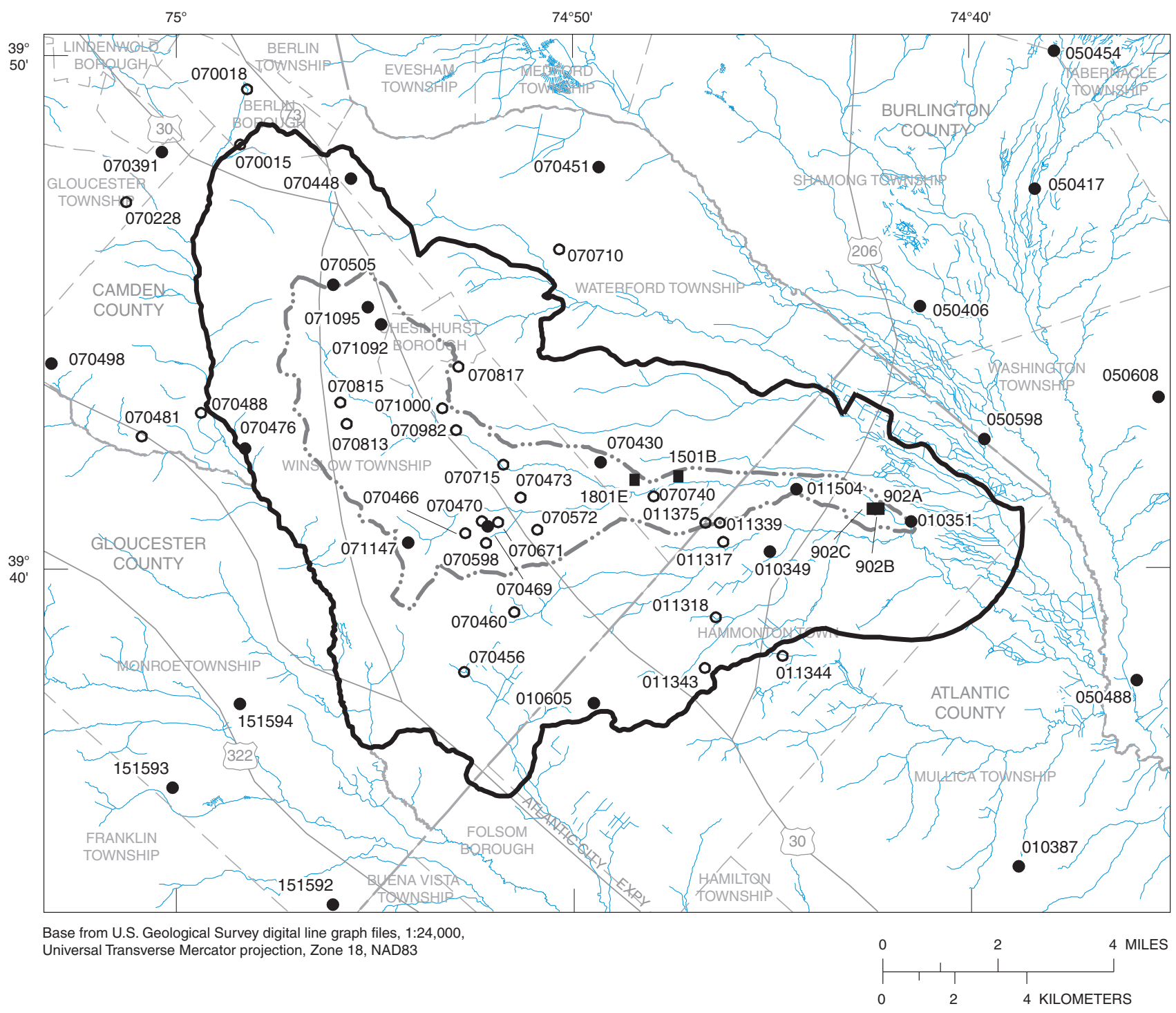

EXPLANATION

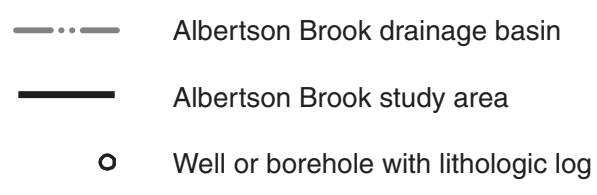

- Well or borehole with geophysical log

- GPR interpretation point

010349 U.S. Geological Survey well number (UID) (table 2)

902B GPR point identifier number. The site name listed in table 2 is the GPR point identifier number preceded by the basin code and data type (ex. ABGPR902B)

Figure 6. Location of boreholes, wells, and ground-penetrating radar (GPR) data points used to describe the hydrogeologic framework of the Albertson Brook study area and vicinity, New Jersey Pinelands. 


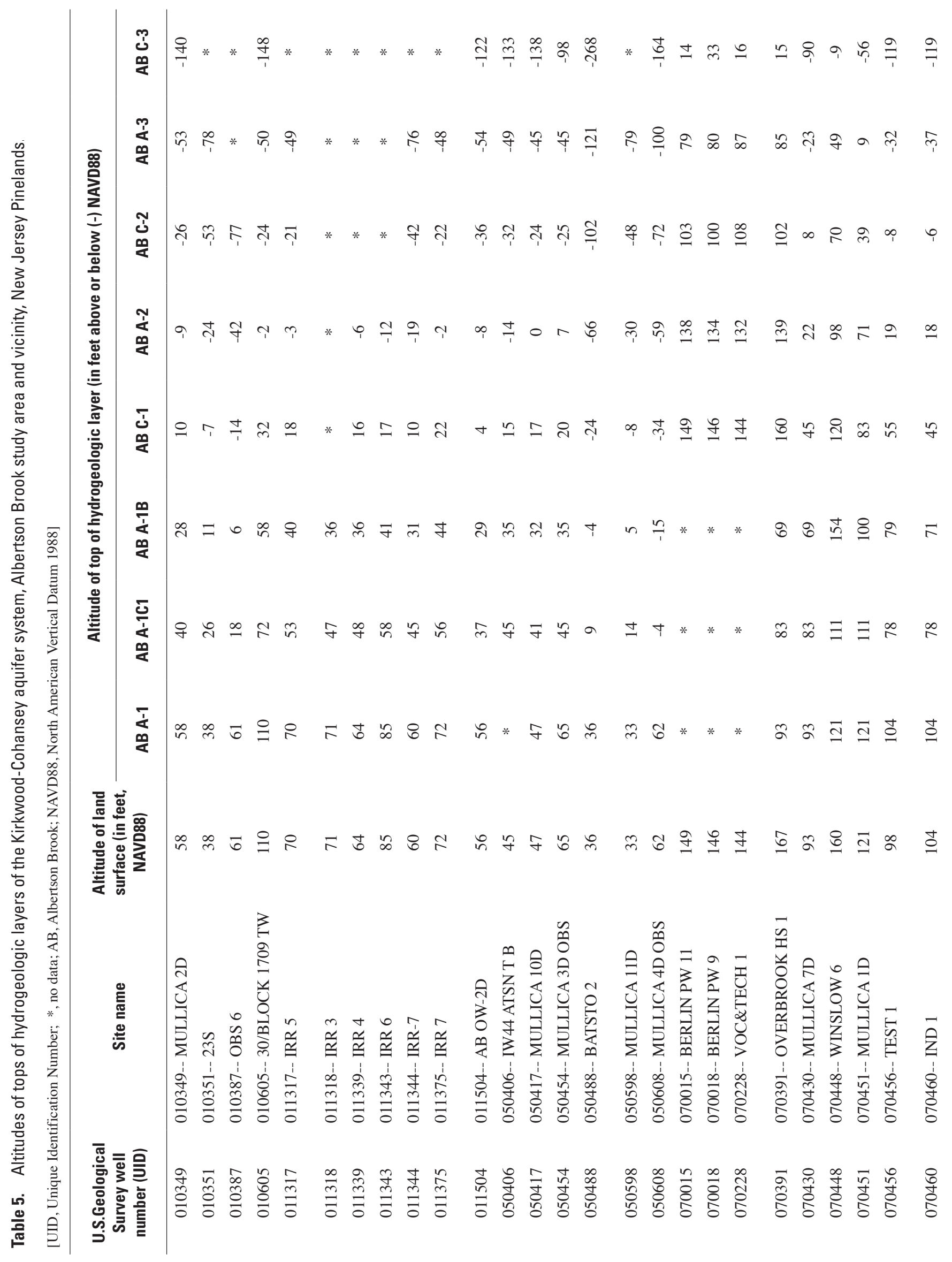




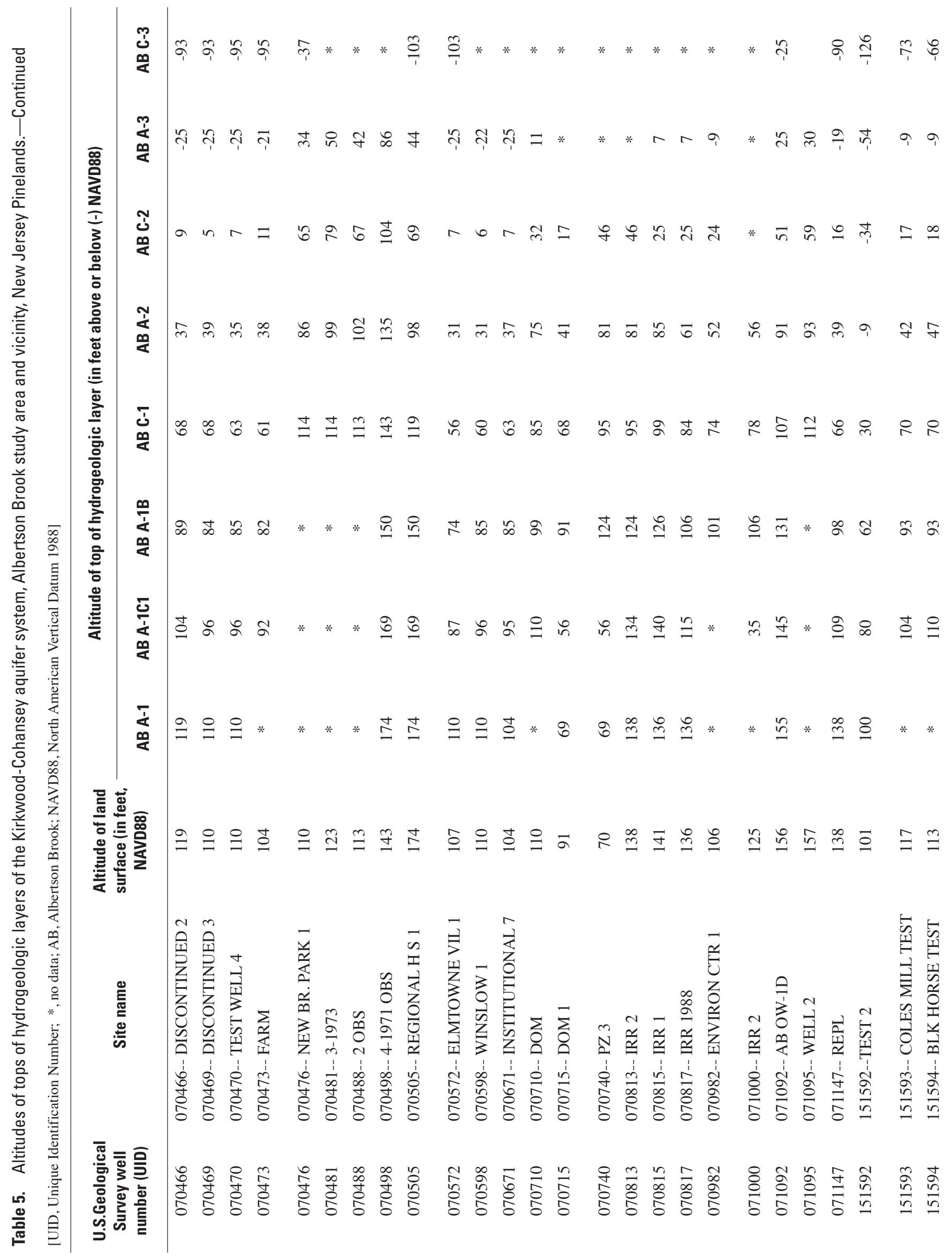




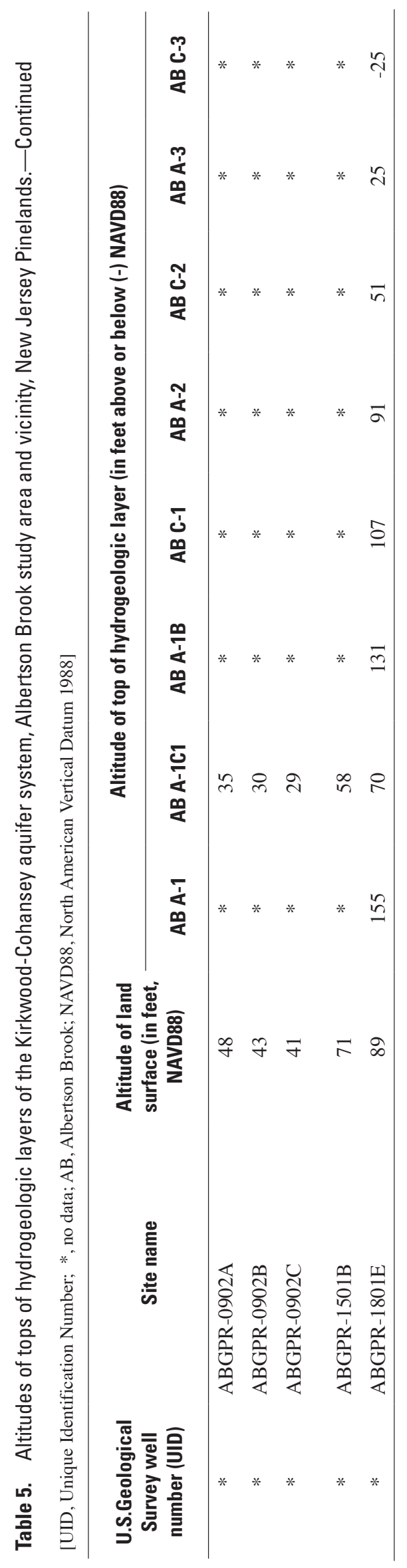




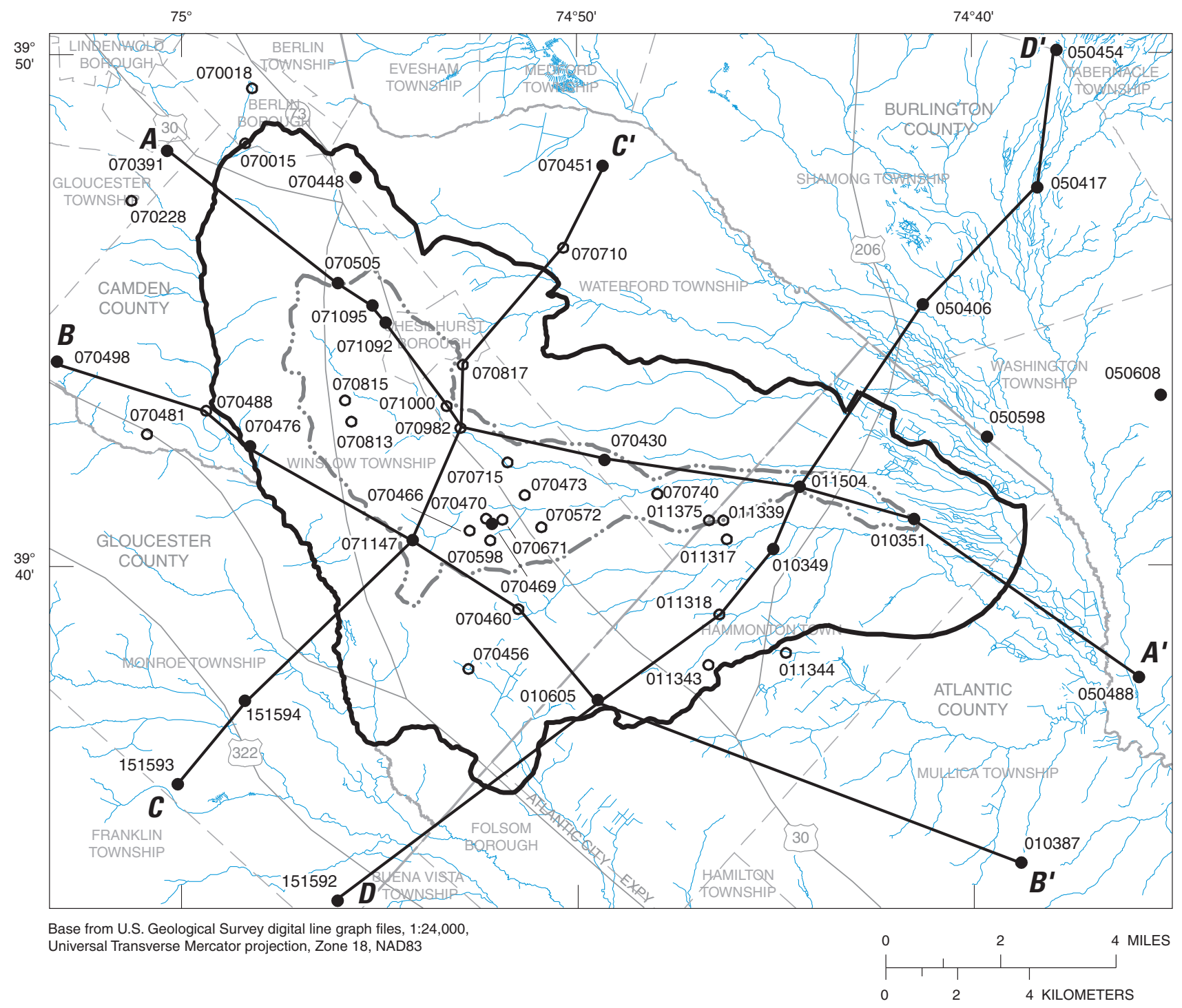

EXPLANATION

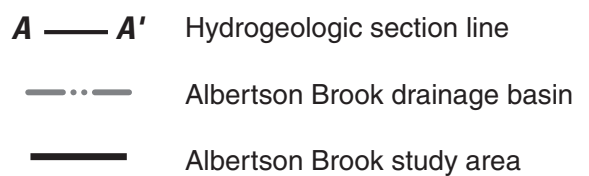

$\boldsymbol{A}-\boldsymbol{A}^{\prime} \quad$ Hydrogeologic section line

Albertson Brook study area
- Well or borehole with lithologic log

- Well or borehole with geophysical log

010349 U.S. Geological Survey well number (UID) (table 2)

Figure 7. Location of hydrogeologic lines of section, and wells or boreholes with lithologic or geophysical data, Albertson Brook study area and vicinity, New Jersey Pinelands. 


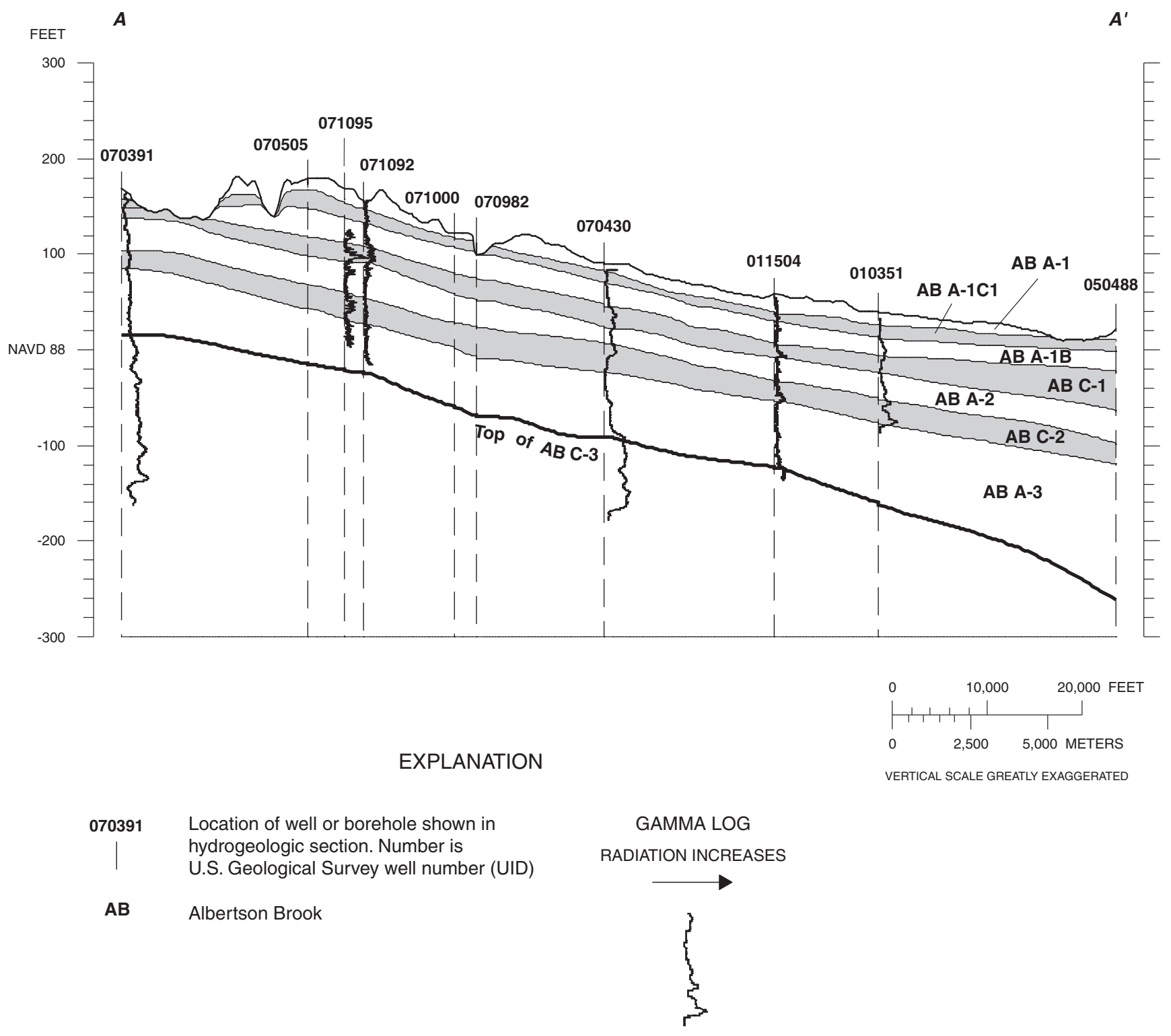

Hydrogeologic framework of the Kirkwood-Cohansey aquifer system in the Alberston Brook study area.

$\begin{array}{ll}\text { Layer } & \text { Description } \\ \text { AB A-1 } & \text { Upper aquifer - upper layer } \\ \text { AB A-1C1 } & \text { Upper leaky - confining layer } \\ \text { AB A-1B } & \text { Upper aquifer - lower layer } \\ \text { AB C-1 } & \text { Middle leaky - confining layer } \\ \text { AB A-2 } & \text { Middle aquifer } \\ \text { AB C-2 } & \text { Lower leaky - confining layer } \\ \text { AB A-3 } & \text { Lower aquifer } \\ \text { AB C-3 } & \text { Lower Kirkwood - confining layer }\end{array}$

Figure 8. Hydrogeologic section $A-A^{\prime}$, Albertson Brook study area and vicinity, New Jersey Pinelands. (Line of section shown on figure 7.) 


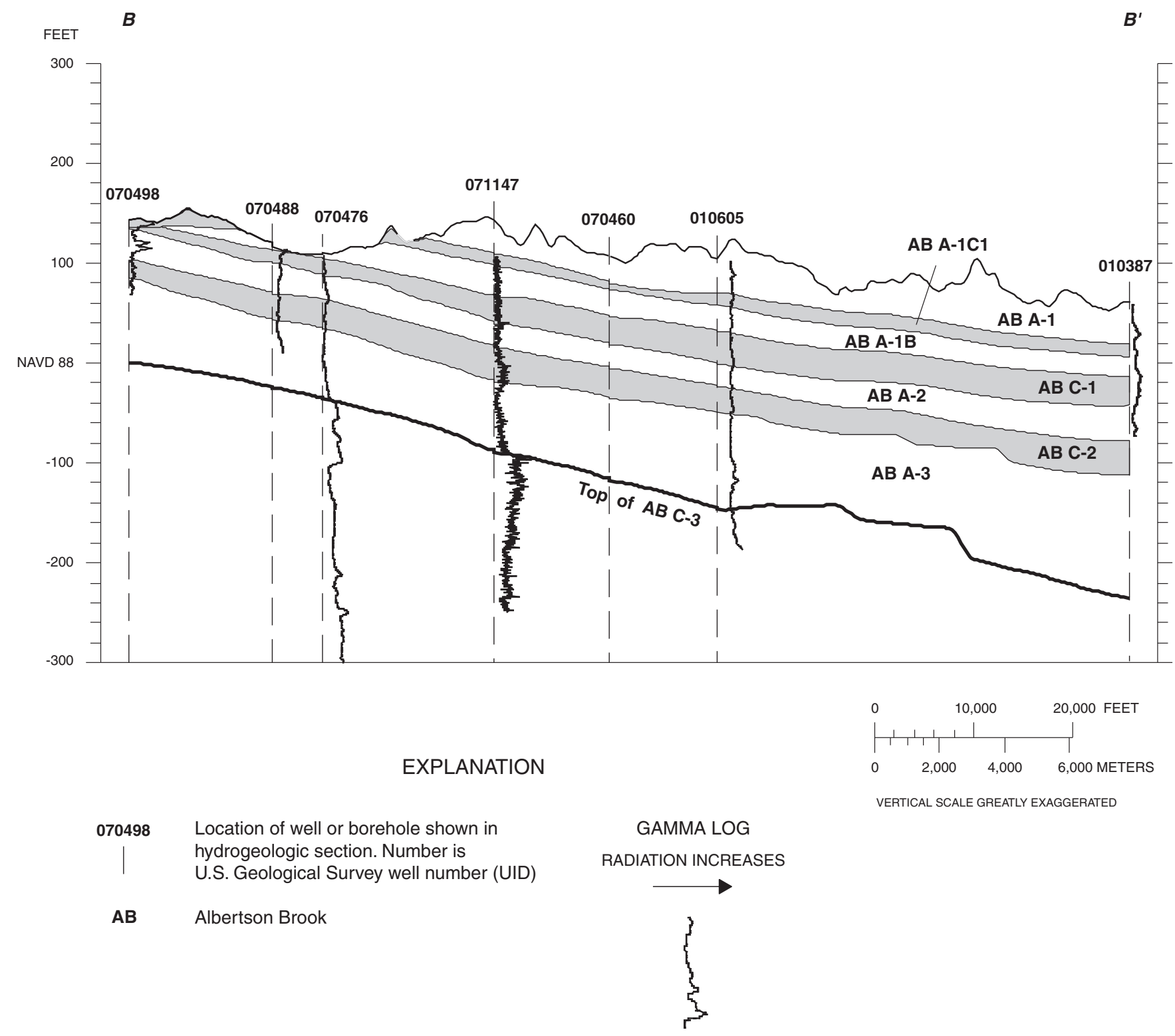

Hydrogeologic framework of the Kirkwood-Cohansey aquifer system in the Alberston Brook study area.

$\begin{array}{ll}\text { Layer } & \text { Description } \\ \text { AB A-1 } & \text { Upper aquifer - upper layer } \\ \text { AB A-1C1 } & \text { Upper leaky - confining layer } \\ \text { AB A-1B } & \text { Upper aquifer - lower layer } \\ \text { AB C-1 } & \text { Middle leaky - confining layer } \\ \text { AB A-2 } & \text { Middle aquifer } \\ \text { AB C-2 } & \text { Lower leaky - confining layer } \\ \text { AB A-3 } & \text { Lower aquifer } \\ \text { AB C-3 } & \text { Lower Kirkwood - confining layer }\end{array}$

Figure 9. Hydrogeologic section $B-B^{\prime}$, Albertson Brook study area and vicinity, New Jersey Pinelands. (Line of section shown on figure 7.) 


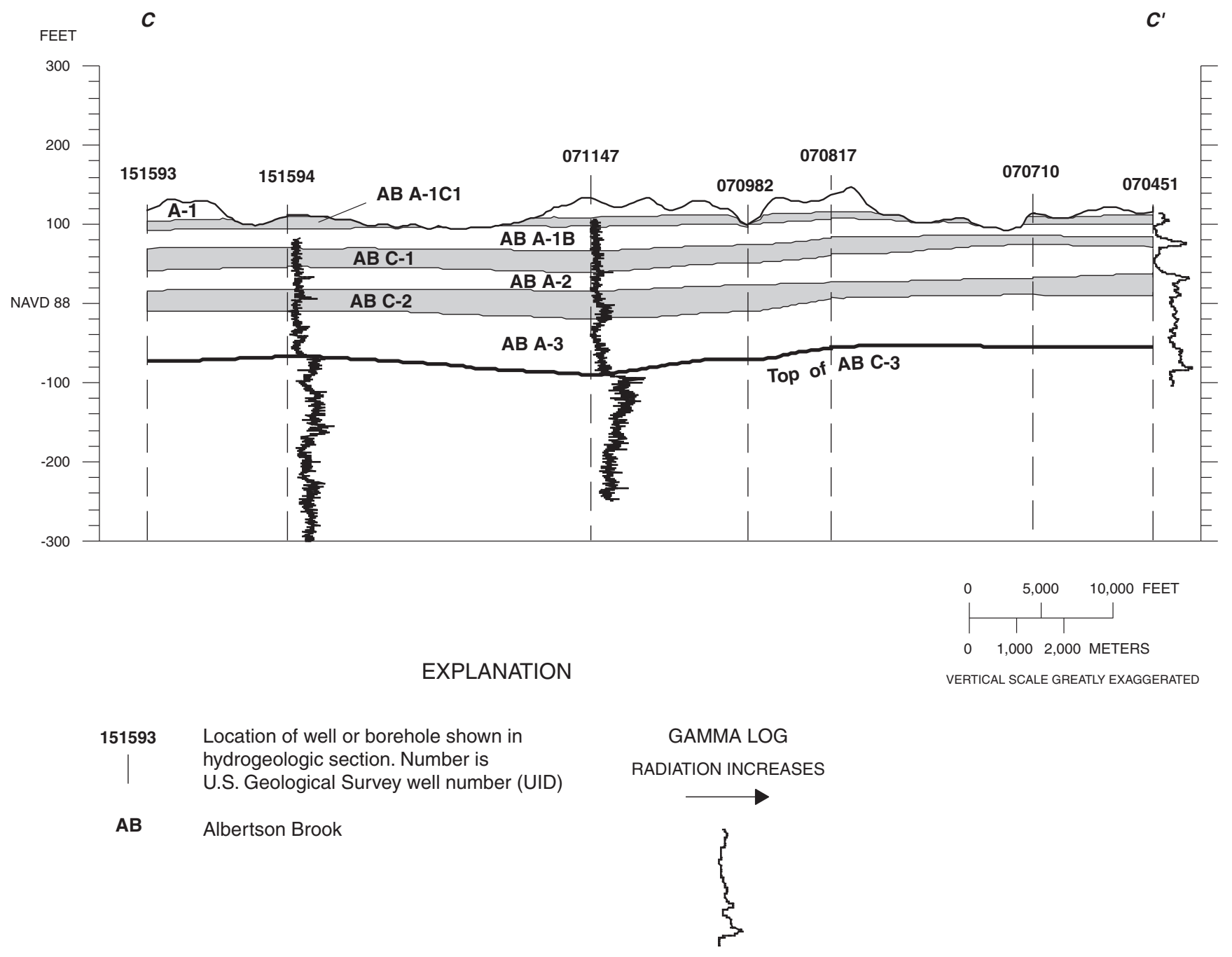

Hydrogeologic framework of the Kirkwood-Cohansey aquifer system in the Alberston Brook study area.

$\begin{array}{ll}\text { Layer } & \text { Description } \\ \text { AB A-1 } & \text { Upper aquifer - upper layer } \\ \text { AB A-1C1 } & \text { Upper leaky - confining layer } \\ \text { AB A-1B } & \text { Upper aquifer - lower layer } \\ \text { AB C-1 } & \text { Middle leaky - confining layer } \\ \text { AB A-2 } & \text { Middle aquifer } \\ \text { AB C-2 } & \text { Lower leaky - confining layer } \\ \text { AB A-3 } & \text { Lower aquifer } \\ \text { AB C-3 } & \text { Lower Kirkwood - confining layer }\end{array}$

Figure 10. Hydrogeologic section $C$ - $C^{\prime}$, Albertson Brook study area and vicinity, New Jersey Pinelands. (Line of section shown on figure 7.) 


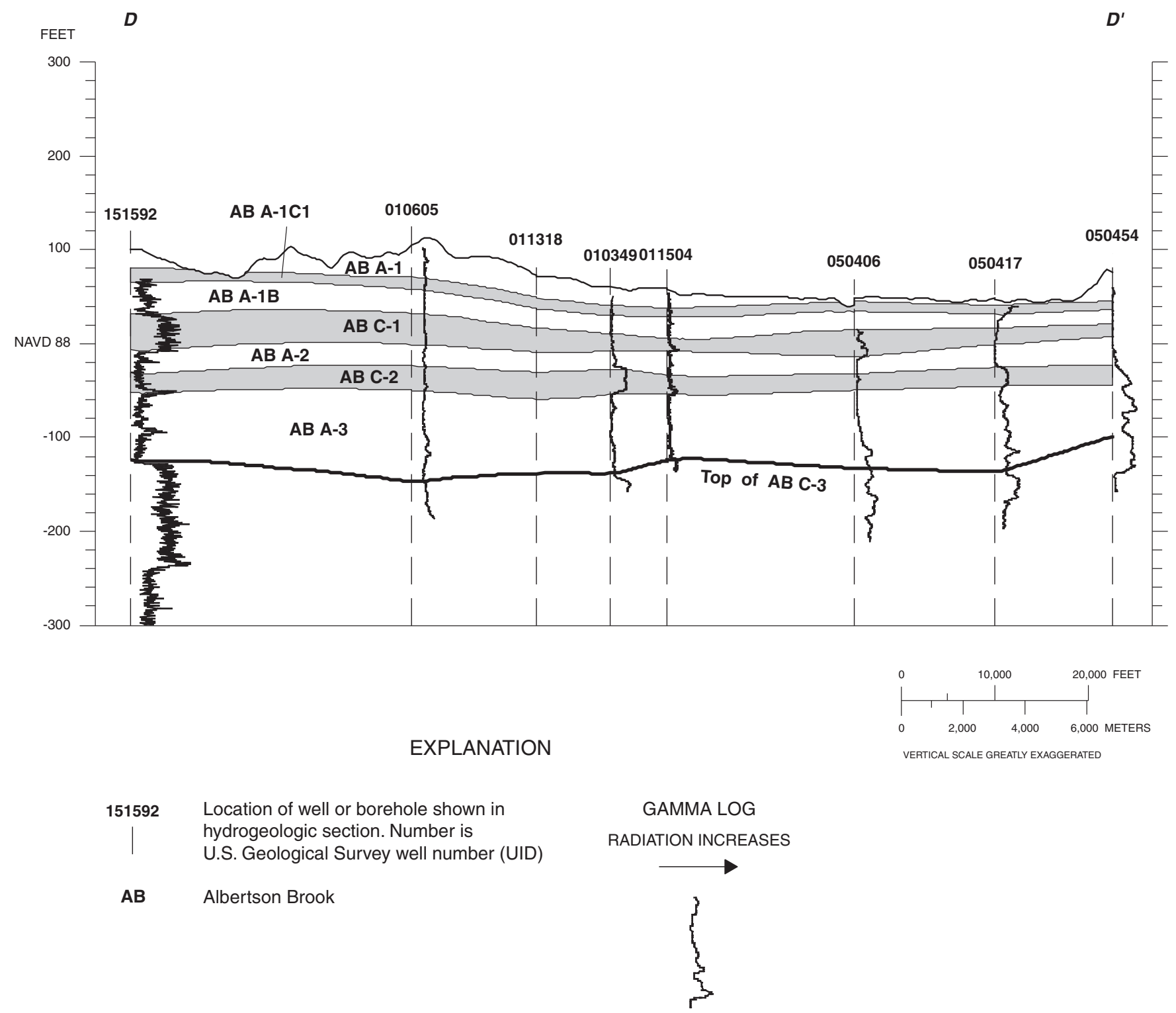

Hydrogeologic framework of the Kirkwood-Cohansey aquifer system in the Alberston Brook study area.

$\begin{array}{ll}\text { Layer } & \text { Description } \\ \text { AB A-1 } & \text { Upper aquifer - upper layer } \\ \text { AB A-1C1 } & \text { Upper leaky - confining layer } \\ \text { AB A-1B } & \text { Upper aquifer - lower layer } \\ \text { AB C-1 } & \text { Middle leaky - confining layer } \\ \text { AB A-2 } & \text { Middle aquifer } \\ \text { AB C-2 } & \text { Lower leaky - confining layer } \\ \text { AB A-3 } & \text { Lower aquifer } \\ \text { AB C-3 } & \text { Lower Kirkwood - confining layer }\end{array}$

Figure 11. Hydrogeologic section $D-D^{\prime}$, Albertson Brook study area and vicinity, New Jersey Pinelands. (Line of section shown on figure 7.) 


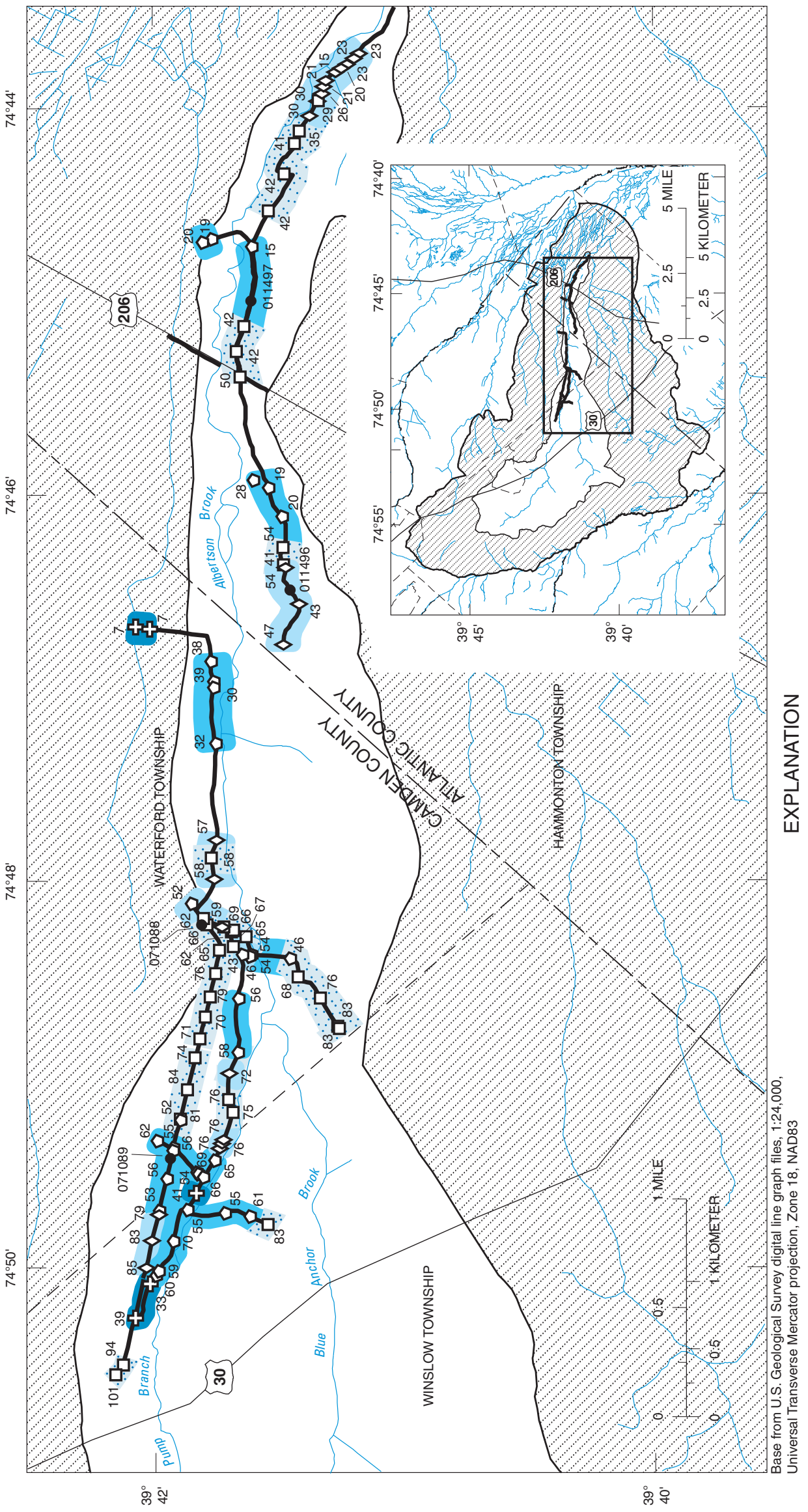

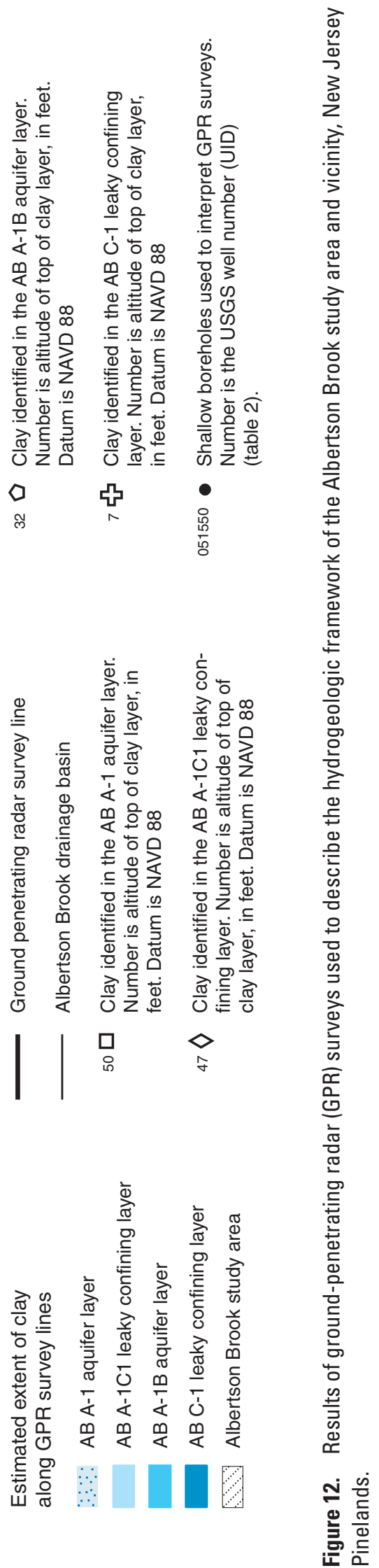




\section{Hydrogeology of McDonalds Branch Study Area and Vicinity}

The base of the Kirkwood-Cohansey aquifer system in the vicinity of the McDonalds Branch study area is the regionally extensive basal clay bed in the lower part of the Kirkwood Formation (Zapecza, 1989). This is the same basal confining bed as that described previously for the Albertson Brook study area; this determination is based on a comparison of the altitude of the top of this basal clay unit with that of Zapecza (1989). As in the Albertson Brook basin, the sands, gravels, and clays in the upper layers of the Kirkwood-Cohansey aquifer system grade to fine sand and eventually silts and clays near the base, forming a gradational contact with the basal clay bed in the lower part of the Kirkwood Formation (Zapecza, 1989; fig. 2).

The McDonalds Branch study area lies within the Central Uplands of the Coastal Plain. In this area, the heavily weathered and eroded upper surface of the Cohansey Sand is capped mostly with Quaternary terraces formed in extensively variable depositional environments. The present day physiographic features depict highly dissected terraces flanked by slope deposits and broad, low gradient valleys covered with sands and gravels eroded from nearby deposits (Newell and others, 2000). Surficial geologic maps by Newell and others (2000) illustrate localized exposures of the Cohansey Sand in the upper part of the McDonalds Branch basin. Pleistocene to Holocene age swamp deposits lie along the stream channels throughout most of the basin. The shallowest hydrogeologic framework layers consist of sediments of the surficial geology described by Newell and others (2000). These layers, depending on location, may contain clay and highly permeable sediments eroded from the Quaternary age terrace and slope deposits that cap much of the Cohansey Sand in this area, the Holocene to Pleistocene age deposits that are found near the streams and swamps, or sediments of the Cohansey Sand where it is exposed in the upper part of the drainage basin.

The headwaters of the McDonalds Branch basin lies on the western slope of the basin divide between the Delaware River and Atlantic Coast basins (not shown). The McDonalds Branch stream winds through an eroded westerly trending valley that drains to the Delaware River through the Rancocas Creek. Soils in the McDonalds Branch basin are principally well-drained deep or loamy sands except where hydric soils are present in areas where the water table is shallow and where muck is present in the vicinity of the swamps and streams (Lord and others, 1990).

The hydrogeologic framework of the McDonalds Branch study area is represented by four aquifer layers separated by three leaky confining layers and a basal confining layer generally represented by the clay confining bed in the lower part of the Kirkwood Formation described by Zapecza (1989). The following list describes the hydrogeologic framework layers for the McDonalds Branch study area and presents their identifiers.

\begin{tabular}{ll}
\hline Layer identifier & $\begin{array}{l}\text { Description of the hydrogeologic frame- } \\
\text { work of the McDonalds Branch study area }\end{array}$ \\
\hline MB A-1 & Upper aquifer - upper layer \\
MB A-1C1 & Upper - leaky confining layer \\
MB A-1B & Upper aquifer - lower layer \\
MB C-1 & Middle leaky confining layer \\
MB A-2 & Middle aquifer \\
MB C-2 & Lower leaky confining layer \\
MB A-3 & Lower aquifer \\
MB C-3 & Lower Kirkwood basal clay \\
\hline
\end{tabular}

The locations of the 45 sites used to describe the hydrogeologic framework for the McDonalds Branch study area are shown in figure 13. Sites include wells, boreholes, and selected GPR data points. Detailed site information is provided in table 2 . The altitudes of the tops of the hydrogeologic layers for the McDonalds Branch study area and vicinity are listed in table 6.

Four hydrogeologic sections (A-A', B-B', C-C', and D-D') were prepared from selected sites (table 2 ) for the McDonalds Branch study area. The locations of these sections are shown in figure 14. Section A-A' (fig. 15) traces from site to site northwest to the southeast, following the orientation of the drainage basin in the direction of the regional dip of Coastal Plain sediments. Section A-A' slices through the framework model showing the regional dip of the hydrogeologic layers and the land-surface altitude sloping toward the northwest away from the divide between the Delaware River and Atlantic Coastal basins (not shown). A 55-ft-thick medium-density clay is represented by MB C-2 a leaky confining layer at the location of well 051074 . Locally, this clay is a substantial barrier to vertical ground-water flow that is absent at nearby well 051560 about $2 \mathrm{mi}$ to the northwest, thus illustrating the discontinuity of thick clay layers typical of the KirkwoodCohansey aquifer system.

Three hydrogeologic sections, B-B', C-C', and D-D' (figs. 16,17 , and 18 respectively) are positioned approximately normal to section A-A' and cross the basin from southwest to northeast (fig. 14). These sections show that layer MB C-2 thickens toward the southeast. The shallow layers are deeply incised and absent in many areas in the lower part of the basin as a result of downcutting that also broadened the stream valleys toward the northwest. The distribution of fine-textured sediments illustrated by the gamma logs indicates the variable nature of the sands and clays associated with the framework layers.

Structure contours were prepared from the altitudes of the tops of seven of the hydrogeologic layers listed in table 6 using methods described previously. A contour map was not prepared for the top or the MB A-1 layer because it is the same as the land surface and is best described by the 10-meter DEM 


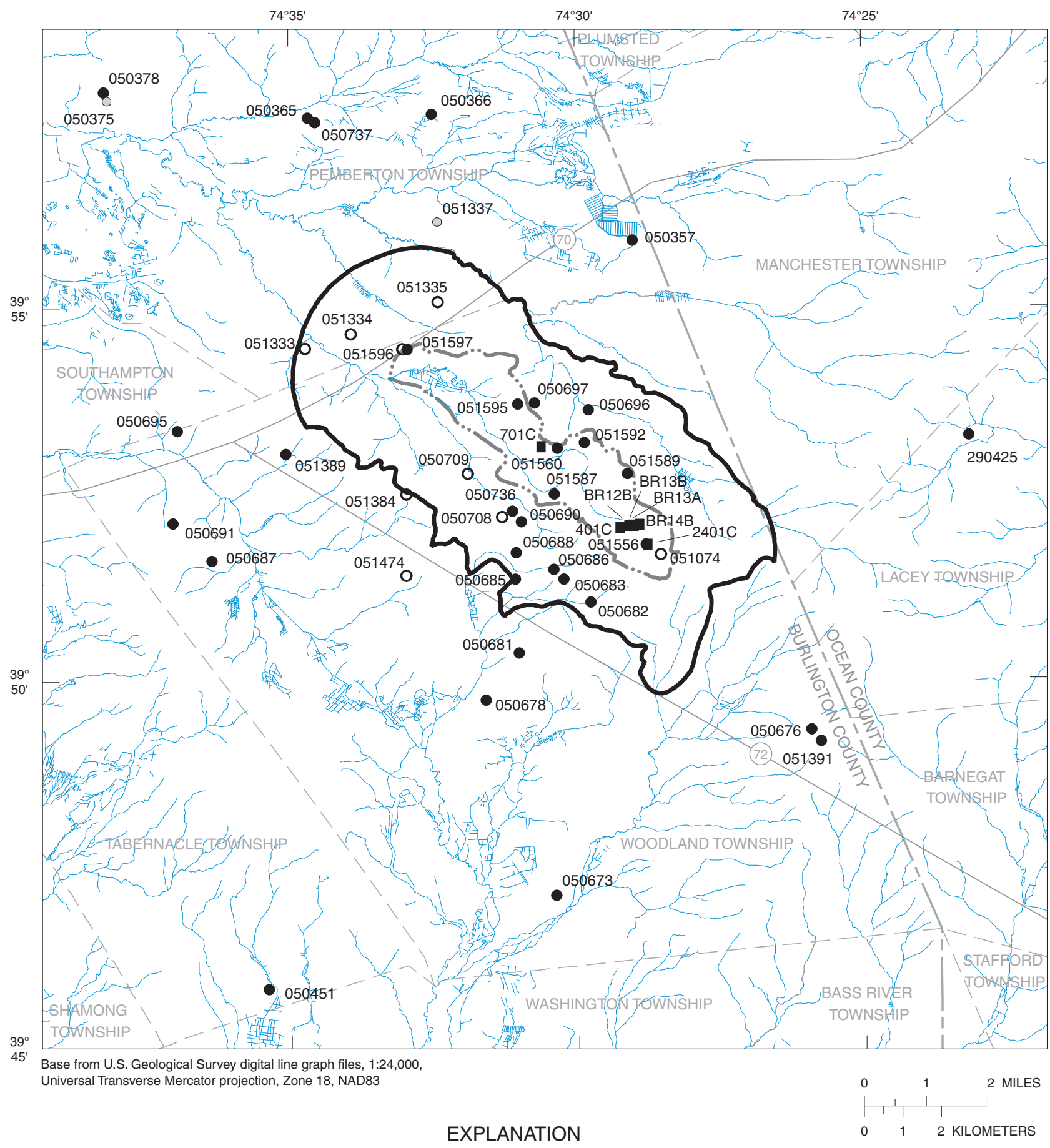

050451 U.S. Geological Survey well number (UID) (table 2)

701C GPR point identifier number. The site name listed in table 2 is the GPR point identifier number preceded by the basin code and data type (ex. MBGPR701C)

BR13A Historic GPR point identifier number. The site name listed in table 2 is the GPR point identifier number preceded by the basin code and data type (ex. MBGPRBR13A)

Figure 13. Location of boreholes, wells, and ground-penetrating radar (GPR) data points used to describe the hydrogeologic framework of the McDonalds Branch study area and vicinity, New Jersey Pinelands. 


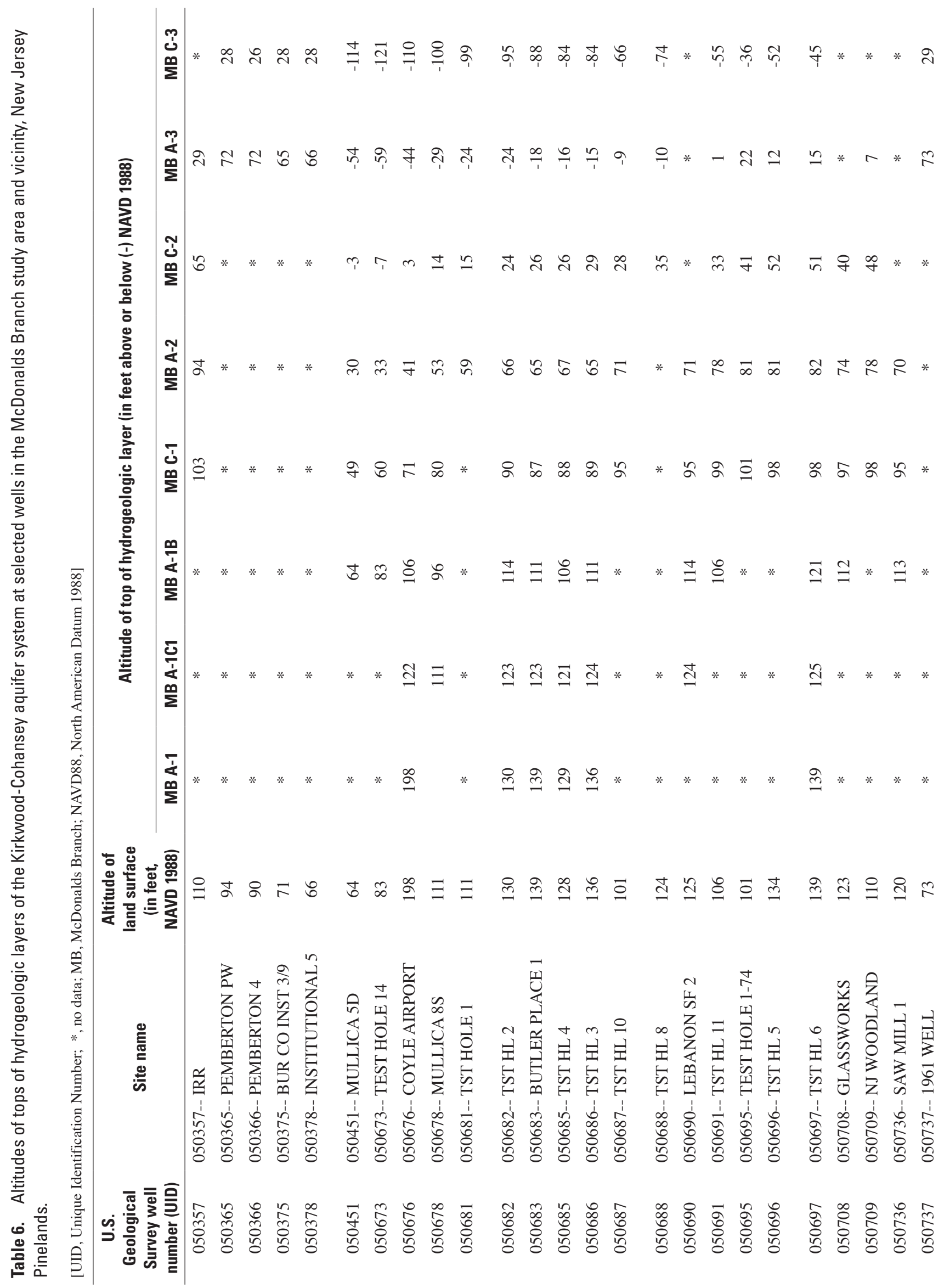




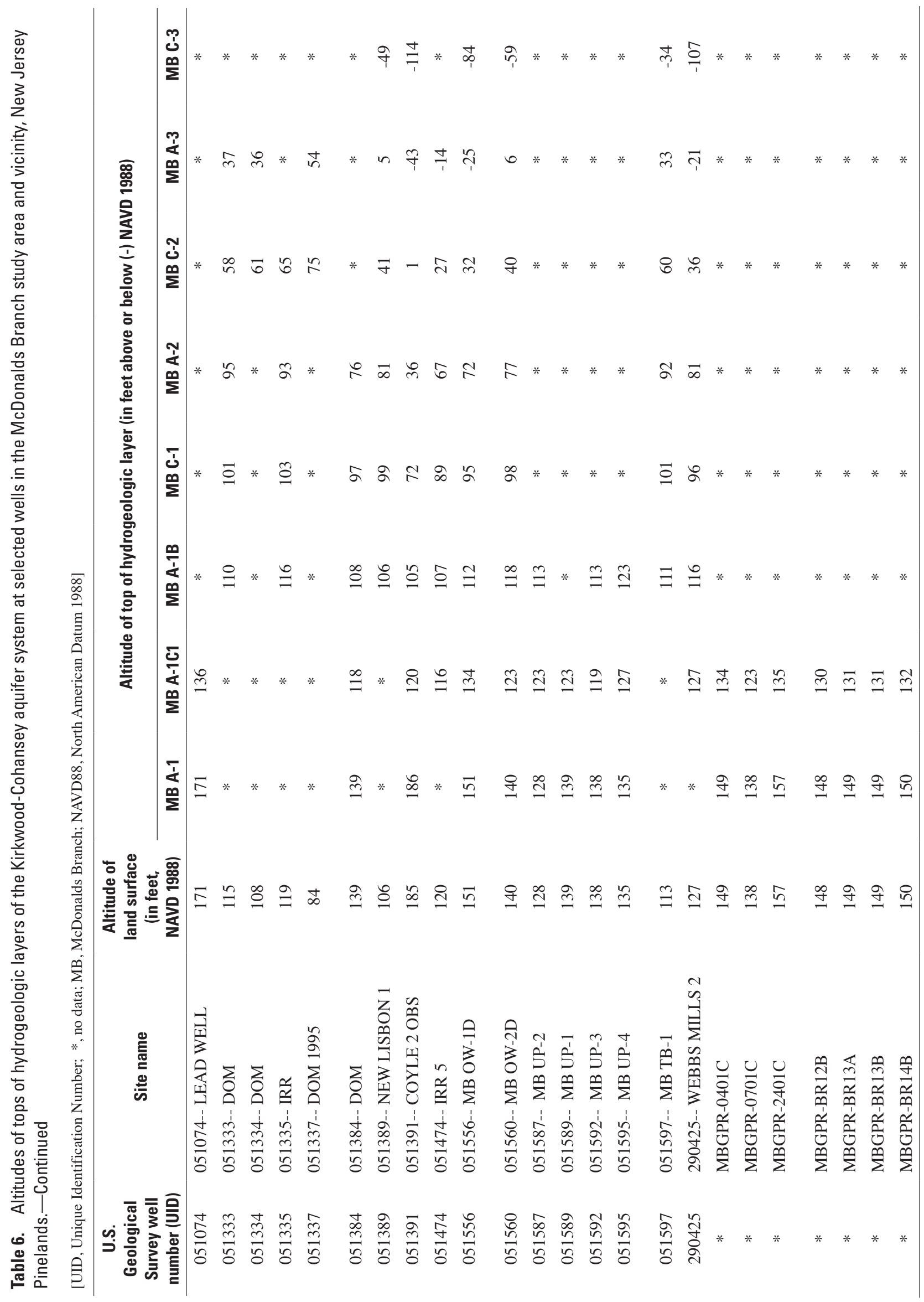




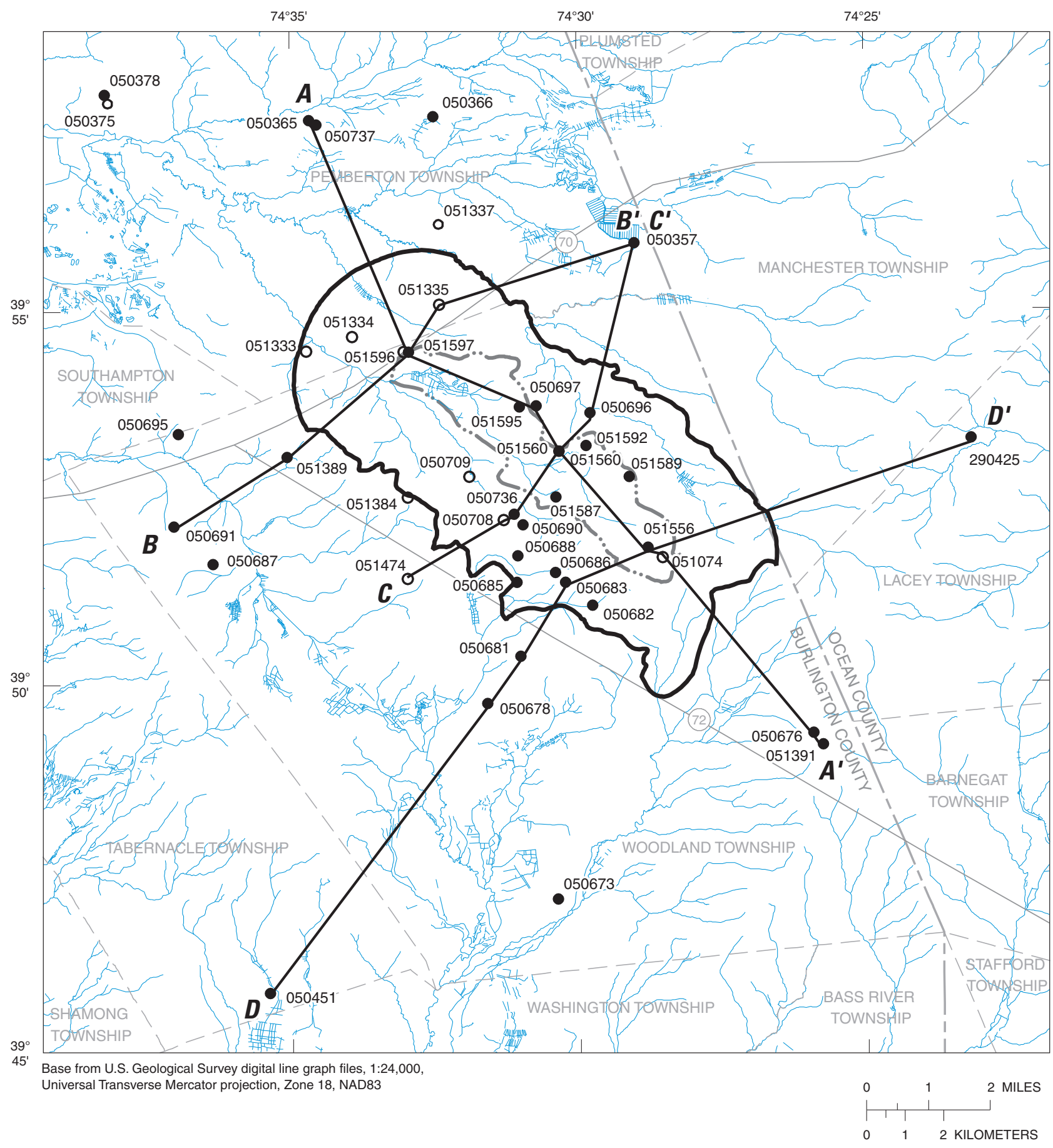

EXPLANATION

$\boldsymbol{A} \boldsymbol{A}^{\prime} \quad$ Hydrogeologic section line

McDonalds Branch drainage basin

McDonalds Branch study area
- Well or borehole with lithologic log

- Well or borehole with geophysical log

050451 U.S. Geological Survey well number (UID) (table 2)

Figure 14. Location of hydrogeologic lines of section, and wells or boreholes with lithologic or geophysical data, McDonalds Branch study area and vicinity, New Jersey Pinelands. 


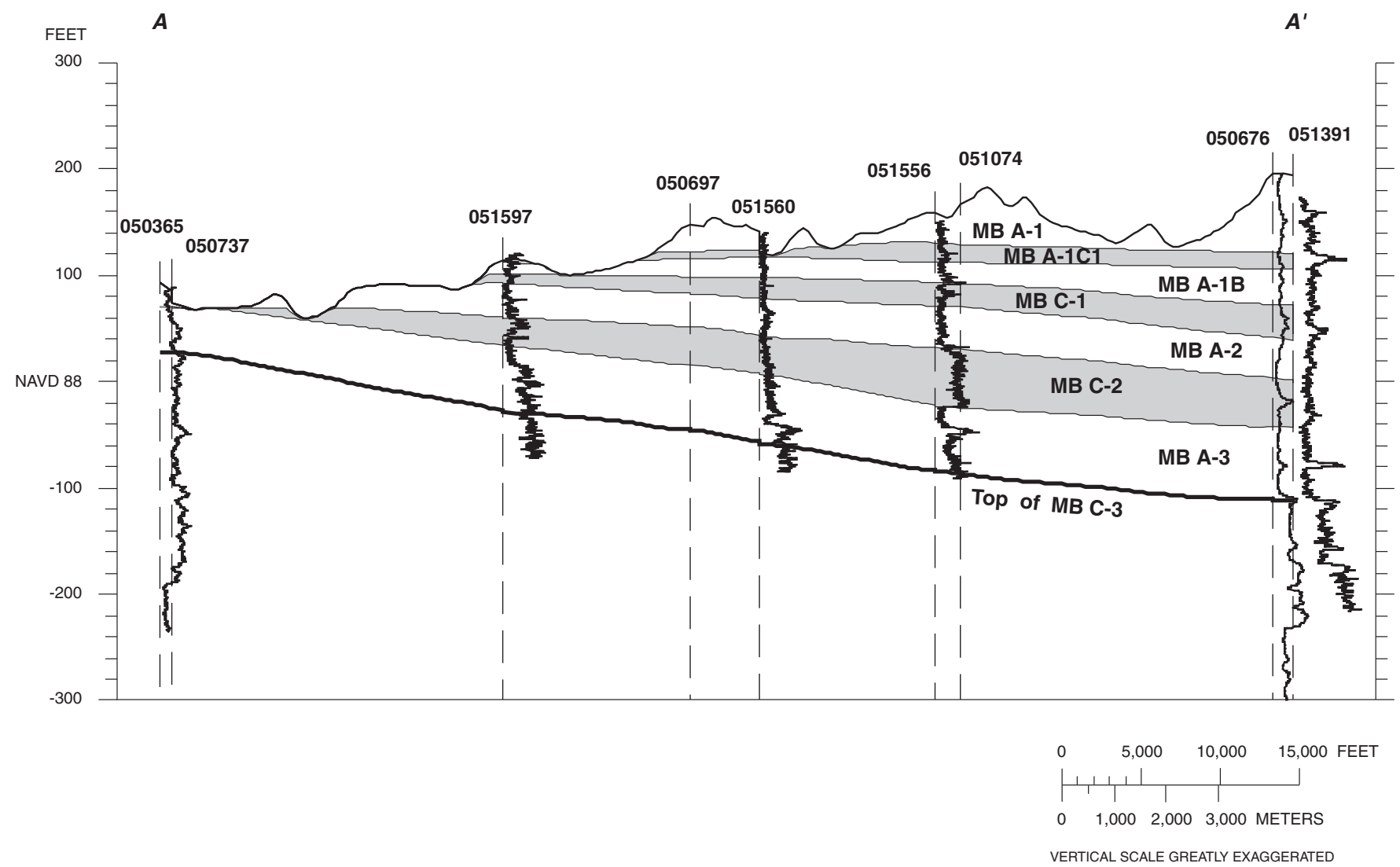

EXPLANATION

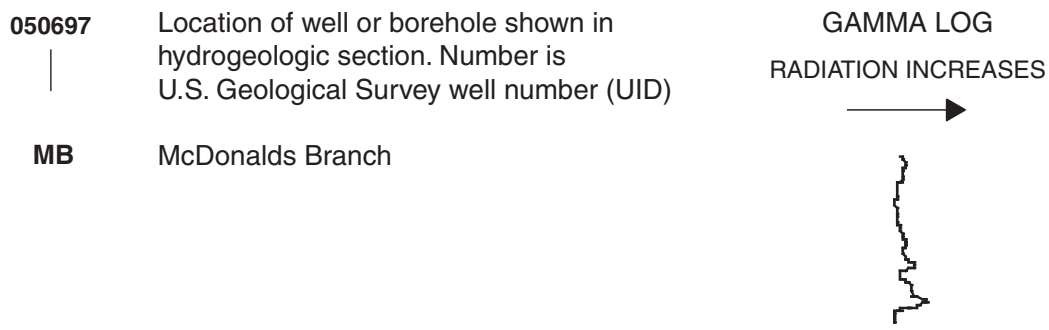

Hydrogeologic framework of the Kirkwood-Cohansey aquifer system in the McDonalds Branch study area.

\begin{tabular}{ll}
\multicolumn{1}{c}{ Layer } & Description \\
MB A-1 & Upper aquifer - upper layer \\
MB A-1C1 & Upper leaky - confining layer \\
MB A-1B & Upper aquifer - lower layer \\
MB C-1 & Middle leaky - confining layer \\
MB A-2 & Middle aquifer \\
MB C-2 & Lower leaky - confining layer \\
MB A-3 & Lower aquifer \\
MB C-3 & Lower Kirkwood - confining layer
\end{tabular}

Figure 15. Hydrogeologic section $A-A^{\prime}$, McDonalds Branch study area and vicinity, New Jersey Pinelands. (Line of section shown on figure 14.) 


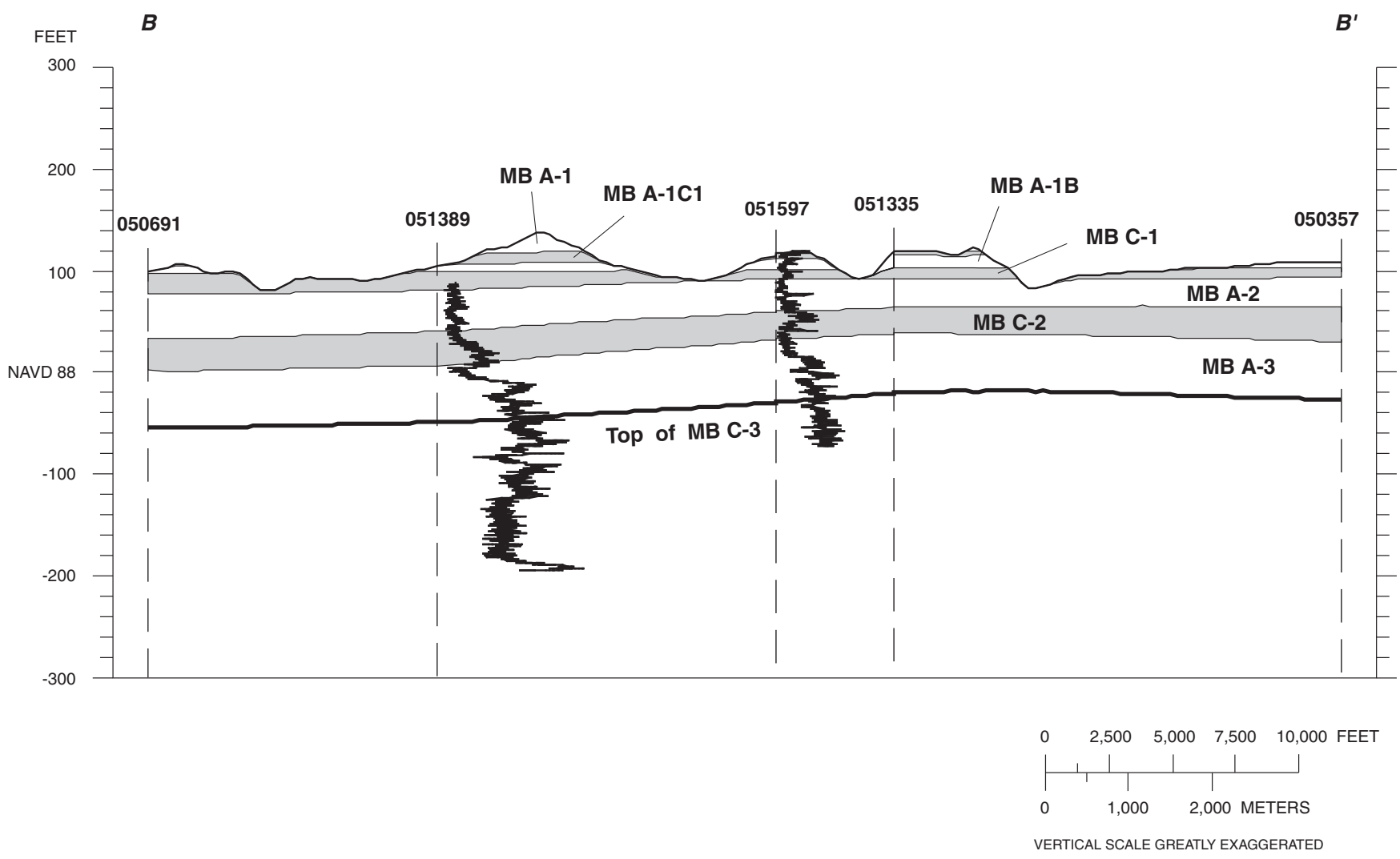

\section{EXPLANATION}

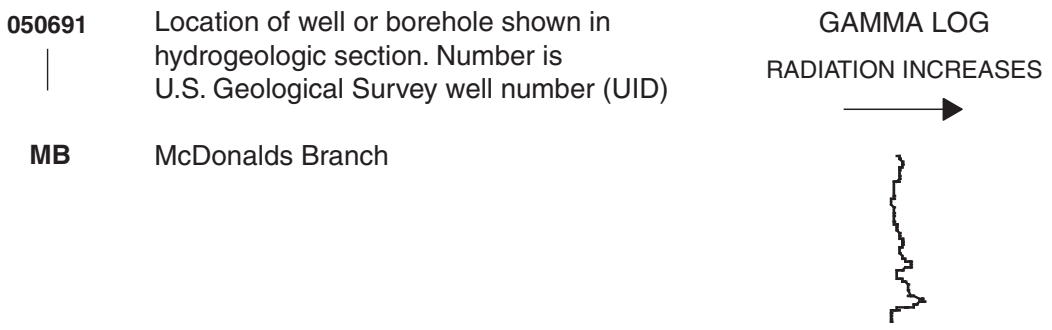

Hydrogeologic framework of the Kirkwood-Cohansey aquifer system in the McDonalds Branch study area.

\begin{tabular}{ll} 
Layer & Description \\
\cline { 2 - 2 } MB A-1 & Upper aquifer - upper layer \\
MB A-1C1 & Upper leaky - confining layer \\
MB A-1B & Upper aquifer - lower layer \\
MB C-1 & Middle leaky - confining layer \\
MB A-2 & Middle aquifer \\
MB C-2 & Lower leaky - confining layer \\
MB A-3 & Lower aquifer \\
MB C-3 & Lower Kirkwood - confining layer
\end{tabular}

Figure 16. Hydrogeologic section $B-B^{\prime}$, McDonalds Branch study area and vicinity, New Jersey Pinelands. (Line of section shown on figure 14.) 


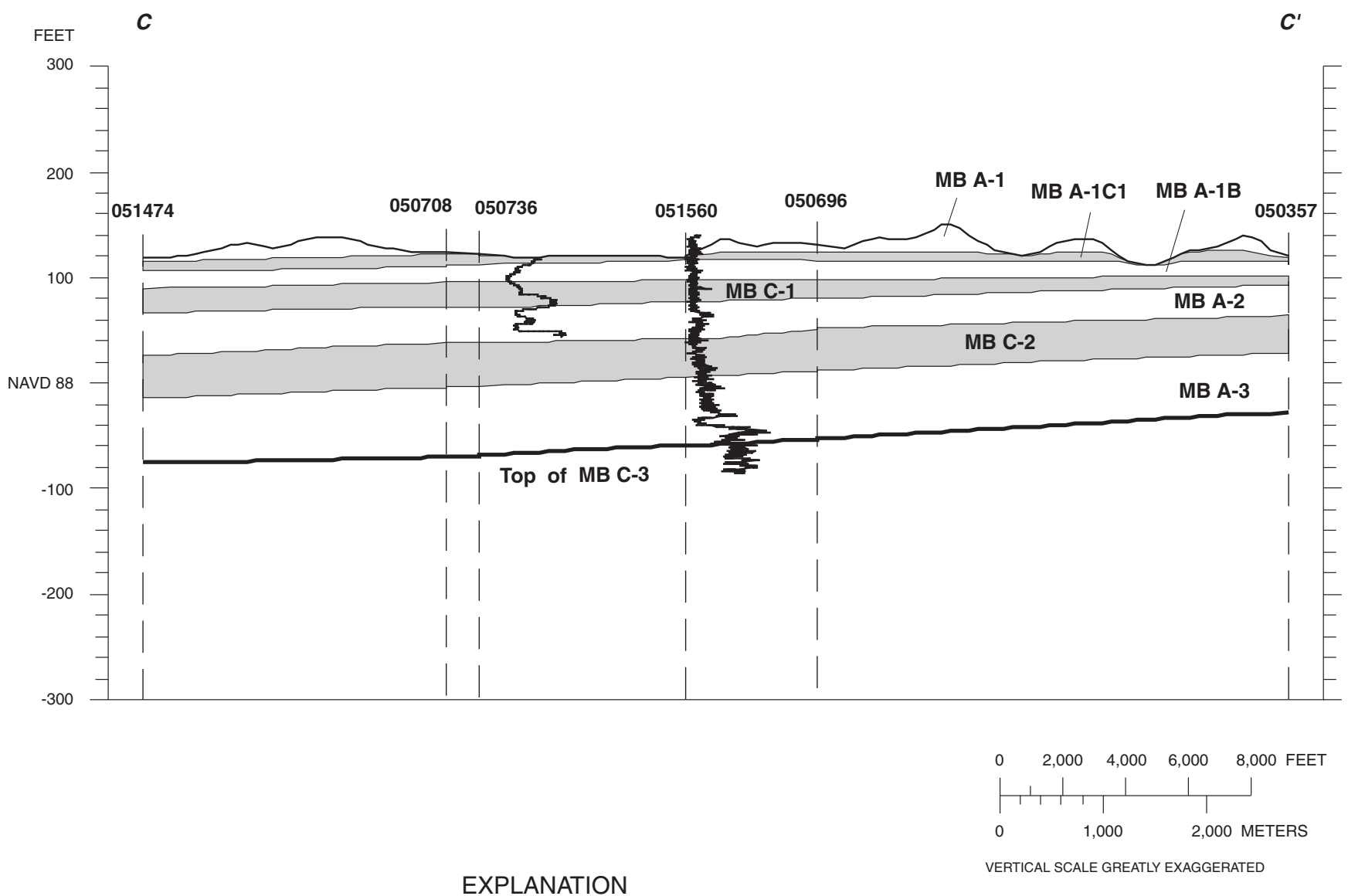

Hydrogeologic framework of the Kirkwood-Cohansey aquifer system in the McDonalds Branch study area.

\begin{tabular}{ll} 
Layer & Description \\
\cline { 2 - 2 } MB A-1 & Upper aquifer - upper layer \\
MB A-1C1 & Upper leaky - confining layer \\
MB A-1B & Upper aquifer - lower layer \\
MB C-1 & Middle leaky - confining layer \\
MB A-2 & Middle aquifer \\
MB C-2 & Lower leaky - confining layer \\
MB A-3 & Lower aquifer \\
MB C-3 & Lower Kirkwood - confining layer
\end{tabular}

Figure 17. Hydrogeologic section $C$ - $C^{\prime}$, McDonalds Branch study area and vicinity, New Jersey Pinelands. (Line of section shown on figure 14.) 


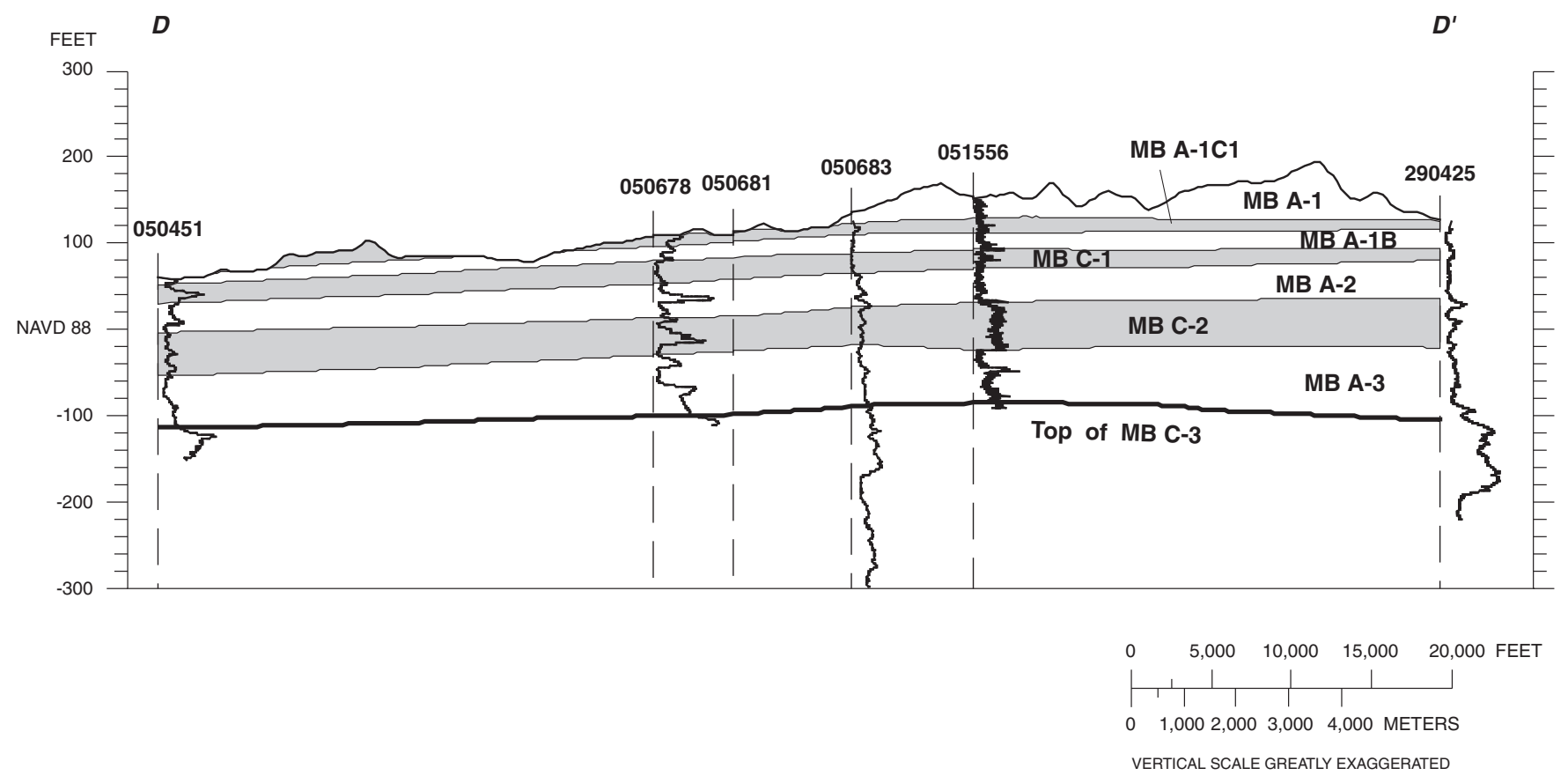

\section{EXPLANATION}

$\begin{array}{ll}050681 & \text { Location of well or borehole shown in } \\ \text { hydrogeologic section. Number is } \\ \text { U.S. Geological Survey well number (UID) }\end{array}$

Hydrogeologic framework of the Kirkwood-Cohansey aquifer system in the McDonalds Branch study area.

$\begin{array}{ll}\text { Layer } & \text { Description } \\ \text { MB A-1 } & \text { Upper aquifer - upper layer } \\ \text { MB A-1C1 } & \text { Upper leaky - confining layer } \\ \text { MB A-1B } & \text { Upper aquifer - lower layer } \\ \text { MB C-1 } & \text { Middle leaky - confining layer } \\ \text { MB A-2 } & \text { Middle aquifer } \\ \text { MB C-2 } & \text { Lower leaky - confining layer } \\ \text { MB A-3 } & \text { Lower aquifer } \\ \text { MB C-3 } & \text { Lower Kirkwood - confining layer }\end{array}$

Figure 18. Hydrogeologic section $D-D^{\prime}$, McDonalds Branch study area and vicinity, New Jersey Pinelands. (Line of section shown on figure 14.) 
pared for seven hydrogeologic layers, but none was prepared for the lower Kirkwood confining layer, MB C-3, because the thickness of this layer was not investigated during this study. (See Zapecza, 1989.) The distribution and range of grain textures estimated for the hydrogeologic layers are shown on the thickness maps. In addition, those $\mathrm{K}$ values that represent individual framework layers (table 4) are shown on their respective thickness maps so that the distribution of $\mathrm{K}$ and the textures can be compared. $\mathrm{K}$ values estimated from well tests (table 4) in the McDonalds Branch basin ranged from $8 \mathrm{ft} /$ day to $269 \mathrm{ft} /$ day, and the average $\mathrm{K}$ was $98 \mathrm{ft} /$ day.The structure contour and thickness maps are presented in appendix 3.

The results of the GPR surveys in the McDonalds Branch study area (fig. 19) confirm the differences in the altitudes of clay surfaces near the McDonalds Branch stream valley. In the areas investigated in the upper part of the basin, GPR records indicated an arealy extensive but discontinuous clay principally associated with the MB A-1C1 leaky confining layer. The top of this clay slopes gently with the shallow stream valley from the upper basin toward the northwest. Because of the slope and apparent discontinuity of this layer it could also represent various overlapping clays that have been eroded to the gradient of the valley. Shallower clays also were identified in the overlying MB A-1 aquifer layer in the upper part of the basin, but this layer is principally sand in most areas, allowing the GPR to penetrate to the deeper layers. Where shallow clays did not obscure the MB C-1 leaky confining layer, only a limited number of MB C-1 clays were identified by GPR surveys. In these areas, overlying sediments and possibly the upper part of the MB C-1 leaky confining layer is composed largely of coarse-grained sediments. Because the Cohansey Sand is exposed in this area, the observed discontinuity of clays most likely conforms to the depositional environment of the Cohansey Sand described by Carter (1978). In the lower part of the basin, GPR records identified the first clay in the MB A-1B aquifer layer over an extensive area. This area forms a low basin divide that is outside the main valley associated with the McDonalds Branch stream, where sediments may have been more resistant to weathering leaving the clay intact.

\section{Hydrogeology of Morses Mill Stream Study Area and Vicinity}

In the Morses Mill Stream study area, the basal confining layer of the Kirkwood-Cohansey aquifer system is the thick diatomaceous clay (fig. 2) that forms an extensive confining bed in the upper part of the Kirkwood Formation dividing the Kirkwood Formation into upper and lower sands. The estimated updip extent of this clay subcrops about 8 mi west of the Morses Mill Stream study area, which indicates either an abrupt change from sand to clay or that the clay was truncated (Zapecza, 1989). From its estimated updip edge, the diatomaceous clay thickens to as much as $200 \mathrm{ft}$ in the vicinity of the study area (Zapecza, 1989, pl. 22-c), isolating the lower part of the Kirkwood Formation beneath it that is referred to locally as the Atlantic City 800-foot sand. The Atlantic City 800-foot sand is considered an artesian aquifer in this area, whereas the overlying the Kirkwood-Cohansey aquifer system is considered unconfined or, locally, a semi-artesian aquifer. The Kirkwood-Cohansey aquifer system overlying the diatomaceous clay is the focus of this study in the Morses Mill Stream study area.

The Kirkwood-Cohansey aquifer system in the Morses Mill study area is composed of sand, gravel, and clay that grade to fine sand, silt, and clay near the base of the aquifer system. Clays, although varying in extent and thickness, are most common in the upper part of the aquifer system probably as a result of the depositional environment of the Cohansey Sand. Many coarse-grained zones are distributed throughout the thickness of the aquifer system, but generally they lie well above the gradational contact with the basal diatomaceous clay. The surficial geology in the Morses Mill Stream study area is similar to that of Albertson Brook study area, as they both straddle the northern limits of the Bridgeton Formation deposits. Surficial geologic maps by Newell and others (2000) indicate that erosion has exposed the Cohansey Sand in some areas surrounding the Morses Mill Stream and its tributaries. Pleistocene to Holocene age swamp deposits have been identified as overlying the Cohansey Sand in the immediate vicinity of the stream channels. In the upper reaches of the basin, these deposits appear to lie directly on the weathered Bridgeton Formation. At the downstream limits of the study area, the Morses Mill Stream drains through a shallow valley eroded through Pleistocene age deposits of the Cape May Formation (Newell and others, 2000). Accordingly the shallowest hydrogeologic layers, depending on location, may contain any of the sediments that make up the surficial deposits within the study area. Soils in the Morses Mill Stream study area generally are moderately well-drained loamy sands with muck soils in the immediate vicinity of swamps and streams (Johnson, 1978).

The hydrogeologic framework of the Morses Mill Stream study area is represented by four aquifer layers separated by three leaky confining layers. The base of the hydrogeologic framework in the vicinity of the study area is the thick diatomaceous clay in the upper part of the Kirkwood Formation (Zapecza,1989). The following list describes the hydrogeologic framework layers for the Morses Mill Stream study area and presents their identifiers. 


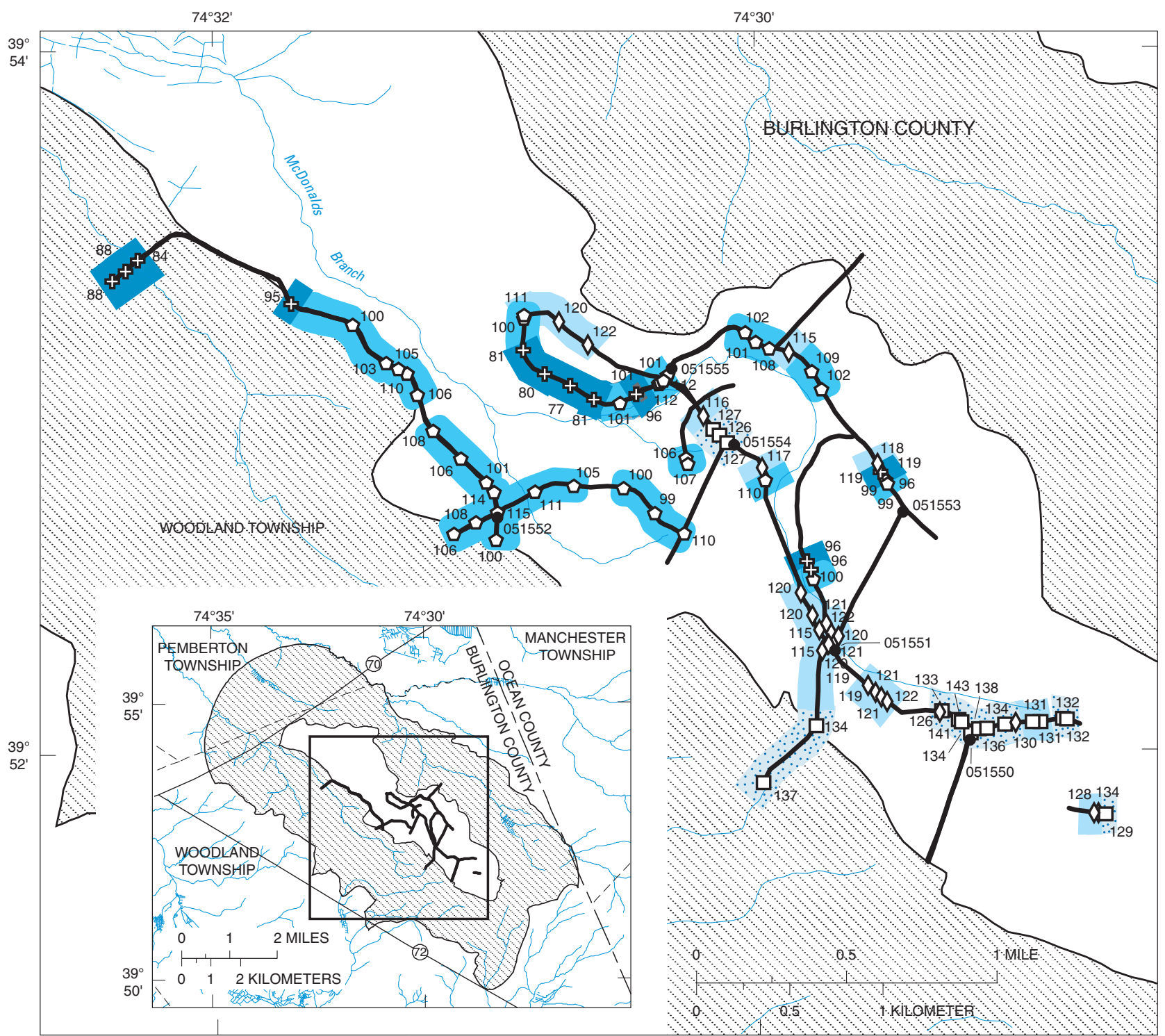

Base from U.S. Geological Survey digital line graph files, 1:24,000, Universal Transverse Mercator projection, Zone 18, NAD83

\section{EXPLANATION}

Estimated extent of clay along GPR survey lines

MB A-1 aquifer layer

MB A-1C1 leaky confining layer

MB A-1B aquifer layer

MB C-1 leaky confining layer

McDonalds Branch study area

Ground penetrating radar survey line

McDonalds Branch drainage basin
137

Clay identified in the MB A-1 aquifer layer. Number is altitude of top of clay layer, in feet. Datum is NAVD 88

${ }_{120} \diamond$ Clay identified in the MB A-1C1 leaky confining layer. Number is altitude of top of clay layer, in feet. Datum is NAVD 88

$100 \square$ Clay identified in the MB A-1B aquifer layer. Number is altitude of top of clay layer, in feet. Datum is NAVD 88

84 引 Clay identified in the MB C-1 leaky confining layer. Number is altitude of top of clay layer, in feet. Datum is NAVD 88
051550

Shallow boreholes used to interpret GPR surveys. Number is the USGS well number (UID) (table 2).

Figure 19. Results of ground-penetrating radar (GPR) surveys used to describe the hydrogeologic framework of the McDonalds Branch study area and vicinity, New Jersey Pinelands. 


\begin{tabular}{ll}
\hline Layer identifier & $\begin{array}{l}\text { Description of the hydrogeologic frame- } \\
\text { work of the Morses Mill Stream study area }\end{array}$ \\
\hline MM A-1 & Upper aquifer - upper layer \\
MM A-1C1 & Upper - leaky confining layer \\
MM A1B & Upper aquifer - lower layer \\
MM C-1 & Middle leaky confining layer \\
MM A-2 & Middle aquifer \\
MM C-2 & Lower leaky confining layer \\
MM A-3 & Lower aquifer \\
MM C-3 & Upper Kirkwood, Diatomaceous clay \\
\hline
\end{tabular}

The locations of the 63 sites used to describe the hydrogeologic framework for the Morses Mill Stream study area are shown in figure 20. Sites include wells and selected GPR data points. Detailed site information is provided in table 2 . The altitudes of the tops of the hydrogeologic layers for the Morses Mill Stream study area and vicinity are listed in table 7.

Four hydrogeologic sections (A-A', B-B', C-C', and D-D') were prepared from selected sites (table 2 ) for the Morses Mill study area. The locations of these sections are shown in figure 21. Two sections, A-A' and B-B' (figs. 22 and 23), trace from site to site slicing through the framework model, in a southeasterly direction normal to the orientation of the drainage basin and in the general direction of the regional dip of Coastal Plain sediments. The two other sections C-C' and D-D' (figs. 24 and 25) lie along with the general orientation of the Morses Mill Stream drainage basin normal to sections A-A' and B-B'. The limited number of geophysial logs available in the vicinity of the Morses Mill Stream study area required a greater reliance on lithologic data than in the other study areas; the geophysical logs illustrated on the sections, although of good quality, tend to be localized within the drainage basin. The distribution of fine-textured sediments illustrated by the gamma logs indicate the variable nature of the sands and clays associated with the framework layers.

Structure contours were prepared from the altitudes of the tops of seven of the hydrogeologic layers at locations listed in table 7 using the methods described previously. A contour map was not prepared for the top or the MM A-1 layer because it is the same as the land surface where the layer exists and is best described by the 10-meter DEM. Thickness maps also were prepared for seven hydrogeologic layers, but none was prepared for the upper Kirkwood confining layer MM C-3 because the thickness of this layer was not investigated during this study. (See Zapecza, 1989.) The distribution and range of textures estimated for the hydrogeologic layers are shown on the thickness maps. In addition, those $\mathrm{K}$ values that represent individual framework layers (table 4) are shown on their respective thickness maps so that the distribution of $\mathrm{K}$ and sediment textures can be compared. $\mathrm{K}$ values estimated from well-performance tests (table 4) in the Morses Mill Stream basin ranged from $17 \mathrm{ft} /$ day to $266 \mathrm{ft} /$ day and the average $\mathrm{K}$ was $84 \mathrm{ft} /$ day.The structure-contour and thickness maps are presented in appendix 4.

The results of the GPR surveys in the Morses Mill Stream study area (fig. 26) confirm only minor differences in the altitudes of clay surfaces identified within the drainage basin. The study area is relatively flat lying and capped locally in the upland parts of the basin with Bridgeton Formation delta plain deposits, and younger sediments locally flank the lower part of the drainage basin. Cohansey Sand sediments are exposed in the shallow erosional valley where Morses Mill Stream lies. The valley is not as deeply incised as those in the other two study areas, and the shallow clays identified in the Morses Mill Stream study area appear to be continuous. In the areas investigated in the upper part of the basin near well 011499, GPR records indicate an extensive continuous clay associated with the surficial MM A-1 aquifer layer. This surficial layer shows some clay in localized areas but the MM A-1 aquifer is generally represented by coarse-grained sediments, and most clays identified in the basin were in the MM A-1C1 leaky confining layer. Clays identified in the MM A-1B aquifer layer appear to be more common in the lower part of the basin, although these clays could be present elsewhere but are obscured in the GPR record by the overlying MM A-1C1 leaky confining layer. 


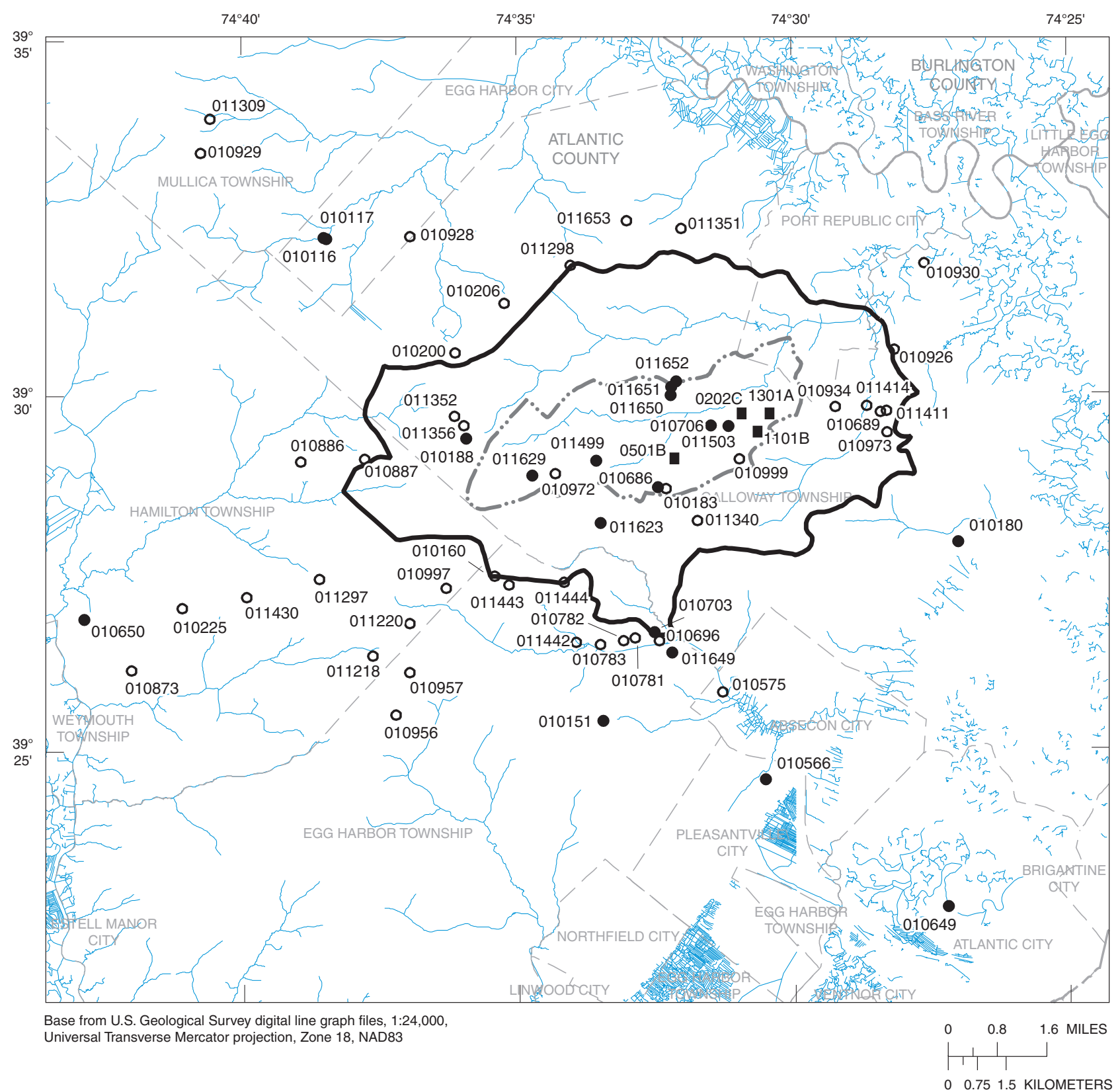

EXPLANATION

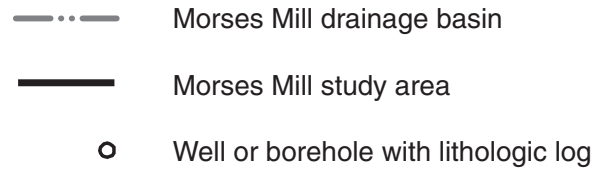

- Well or borehole with geophysical log

- GPR interpretation points

050451 U.S. Geological Survey well number (UID) (table 2)

0202C GPR point identifier number. The site name listed in table 2 is the GPR point identifier number preceded by the basin code and data type (ex. MMGPR0202C)

Figure 20. Location of boreholes, wells, and ground-penetrating radar (GPR) data points used to describe the hydrogeologic framework of the Morses Mill Stream study area and vicinity, New Jersey Pinelands. 


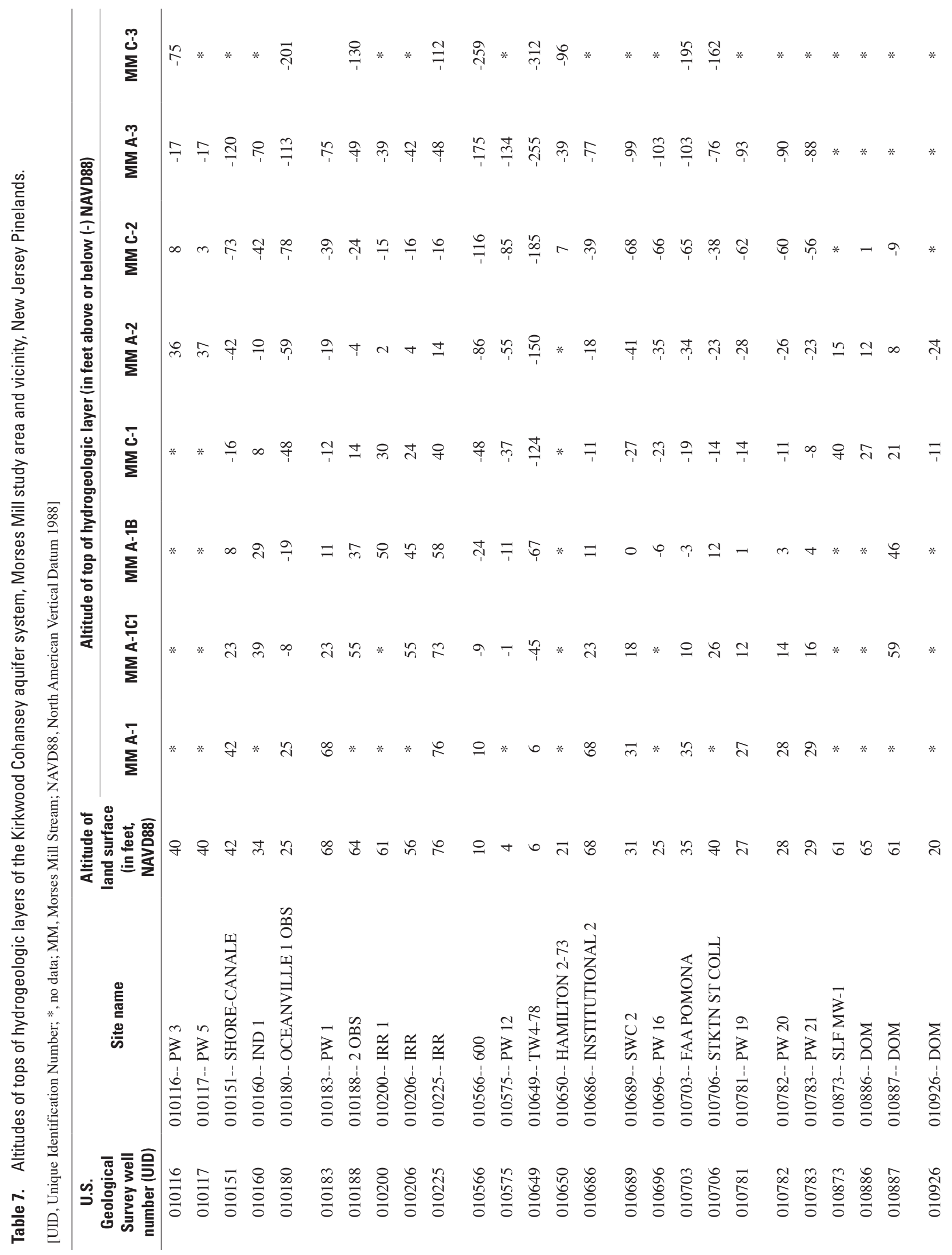




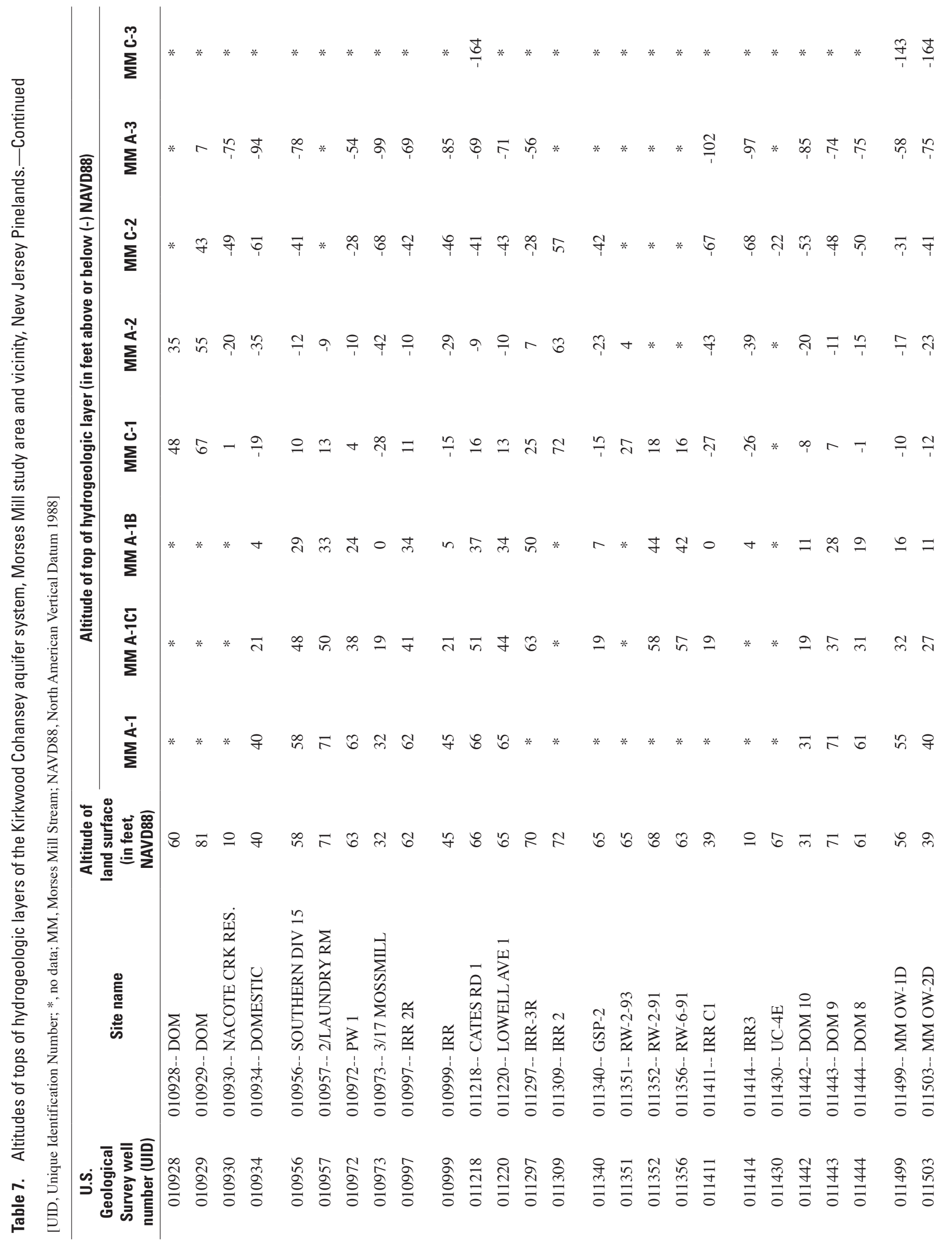




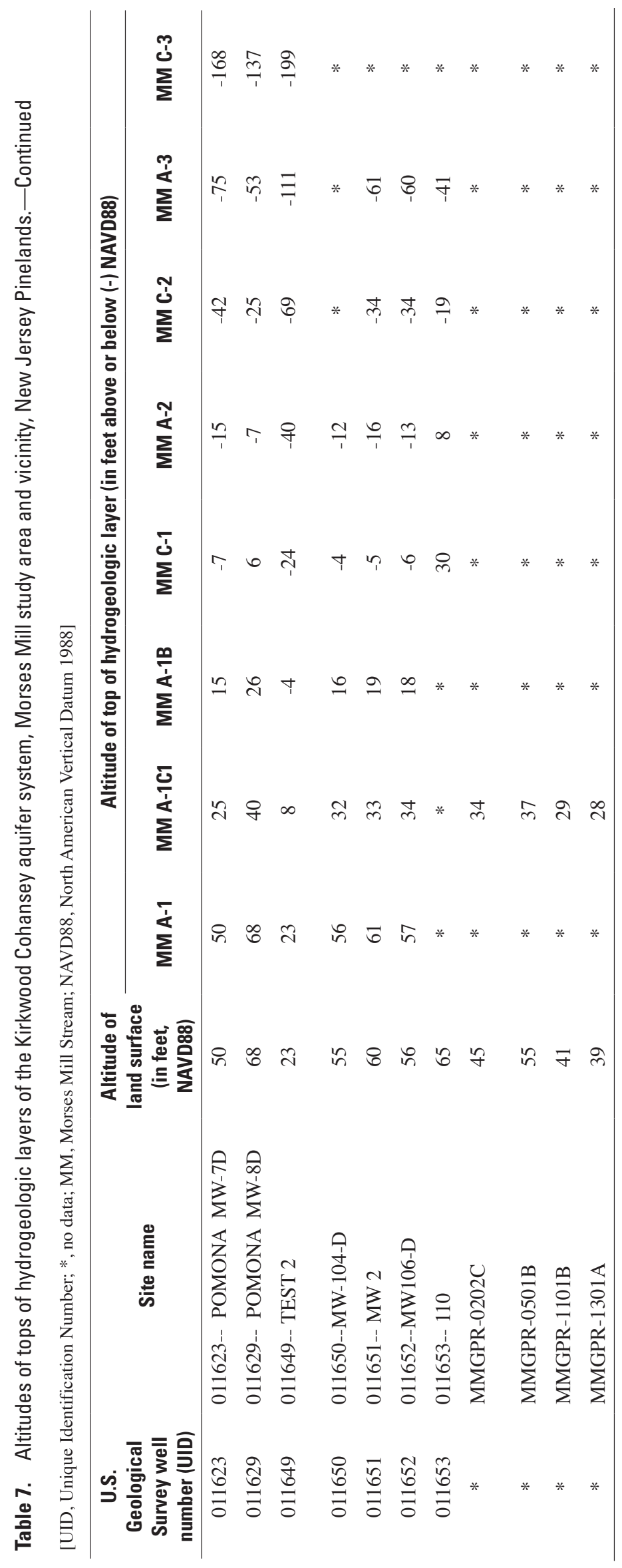




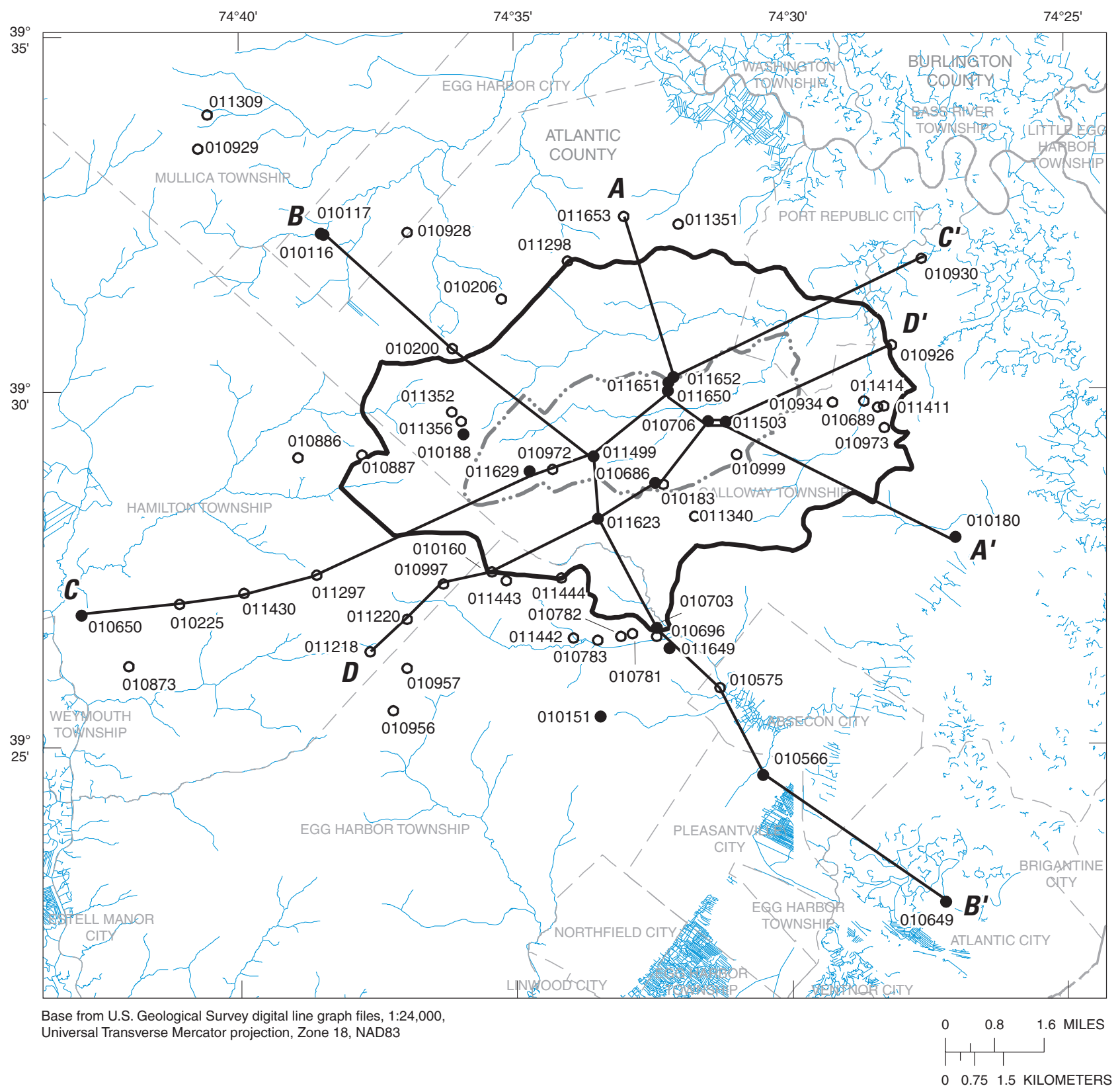

EXPLANATION

$\boldsymbol{A}=\boldsymbol{A}^{\prime}$ Hydrogeologic section line

Morses Mill Stream drainage basin

Morses Mill Stream study area
- Well or borehole with lithologic log

- Well or borehole with geophysical log

010349 U.S. Geological Survey well number (UID) (table 2)

Figure 21. Location of hydrogeologic lines of section, and wells or boreholes with lithologic or geophysical data, Morses Mill Stream study area and vicinity, New Jersey Pinelands. 


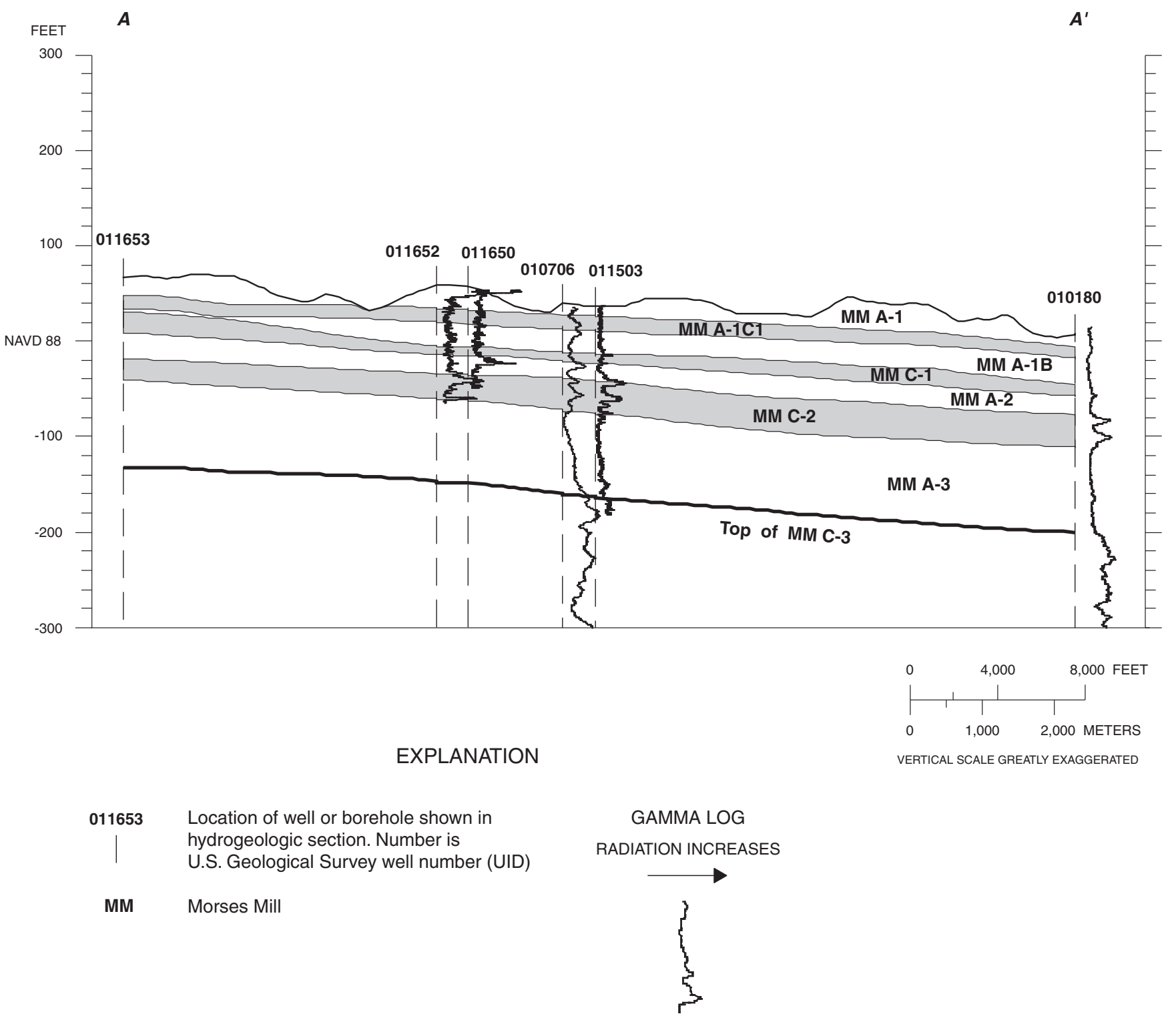

Hydrogeologic framework of the Kirkwood-Cohansey aquifer system in the Morses Mill study area.

\begin{tabular}{ll}
\multicolumn{1}{c}{ Layer } & Description \\
MM A-1 & Upper aquifer - upper layer \\
MM A-1C1 & Upper leaky - confining layer \\
MM A-1B & Upper aquifer - lower layer \\
MM C-1 & Middle leaky - confining layer \\
MM A-2 & Middle aquifer \\
MM C-2 & Lower leaky - confining layer \\
MM A-3 & Lower aquifer \\
MM C-3 & Upper Kirkwood - confining layer
\end{tabular}

Figure 22. Hydrogeologic section $A-A^{\prime}$, Morses Mill Stream study area and vicinity, New Jersey Pinelands. (Line of section shown on figure 21.) 


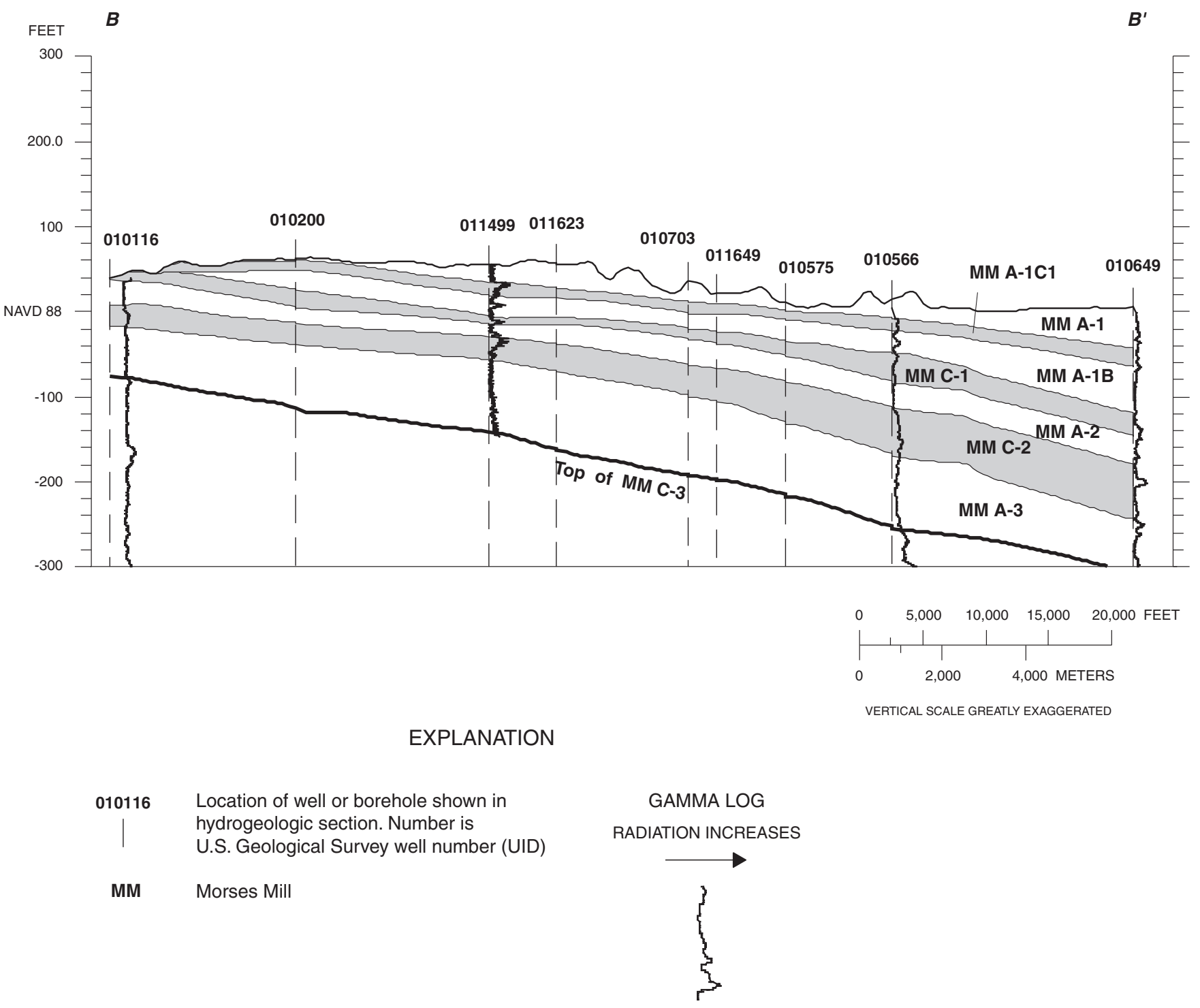

Hydrogeologic framework of the Kirkwood-Cohansey aquifer system in the Morses Mill study area.

\begin{tabular}{ll}
\multicolumn{1}{c}{ Layer } & Description \\
MM A-1 & Upper aquifer - upper layer \\
MM A-1C1 & Upper leaky - confining layer \\
MM A-1B & Upper aquifer - lower layer \\
MM C-1 & Middle leaky - confining layer \\
MM A-2 & Middle aquifer \\
MM C-2 & Lower leaky - confining layer \\
MM A-3 & Lower aquifer \\
MM C-3 & Upper Kirkwood - confining layer
\end{tabular}

Figure 23. Hydrogeologic section $B-B^{\prime}$, Morses Mill Stream study area and vicinity, New Jersey Pinelands. (Line of section shown on figure 21.) 


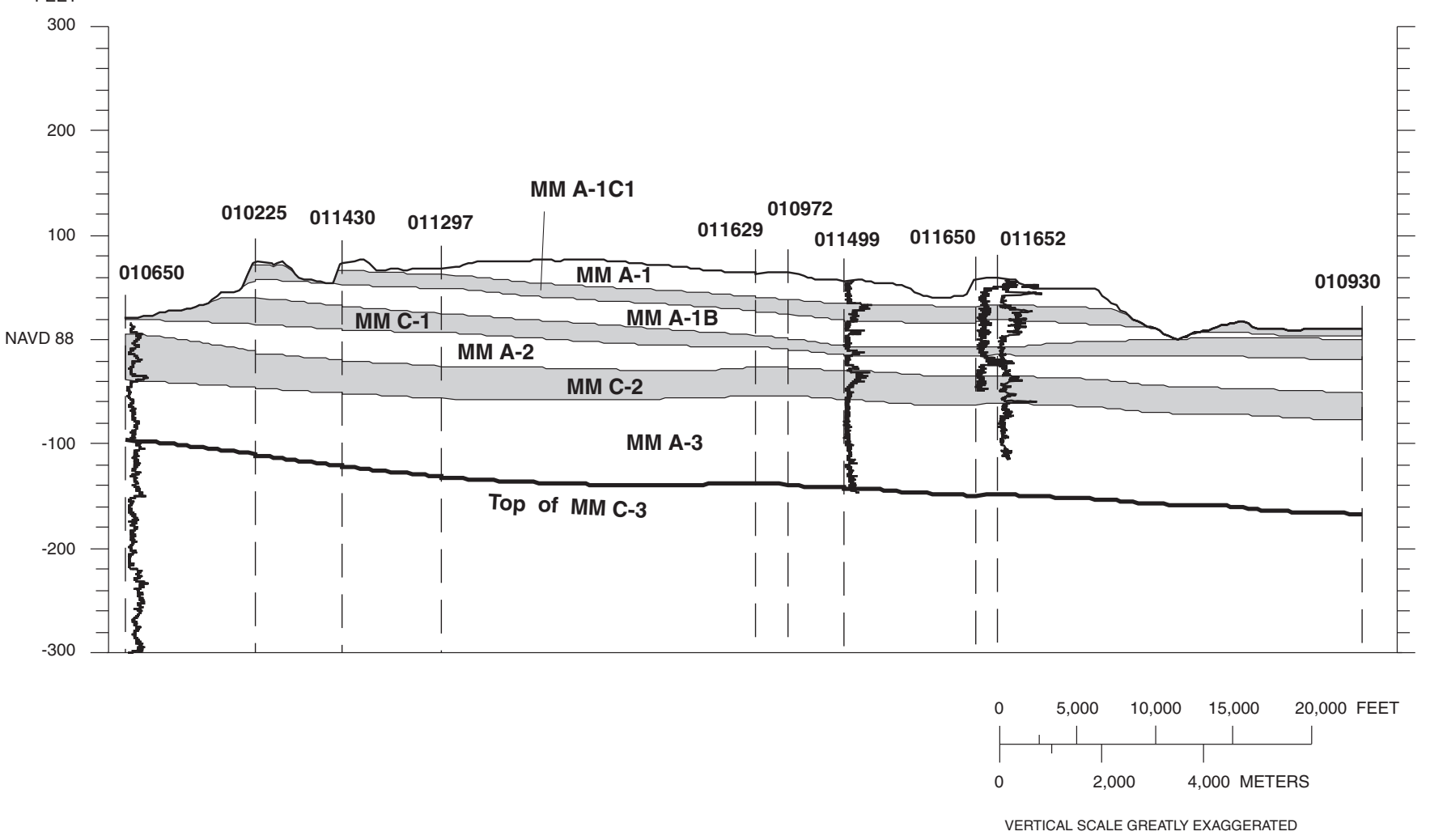

\section{EXPLANATION}

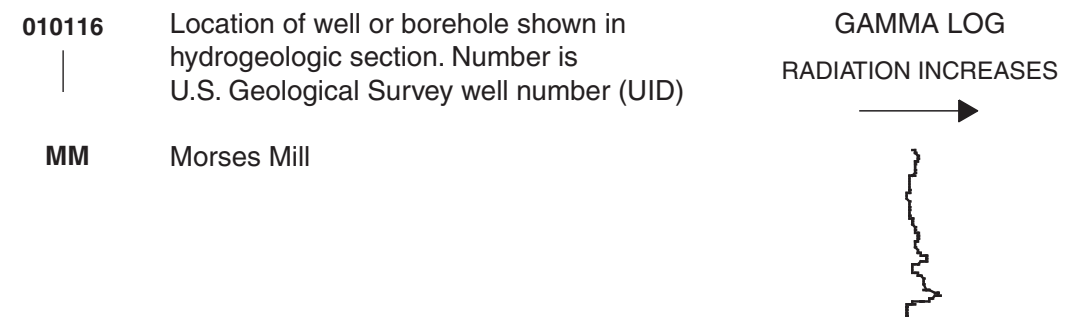

Hydrogeologic framework of the Kirkwood-Cohansey aquifer system in the Morses Mill study area.

\begin{tabular}{ll} 
Layer & Description \\
\cline { 2 - 2 } MM A-1 & Upper aquifer - upper layer \\
MM A-1C1 & Upper leaky - confining layer \\
MM A-1B & Upper aquifer - lower layer \\
MM C-1 & Middle leaky - confining layer \\
MM A-2 & Middle aquifer \\
MM C-2 & Lower leaky - confining layer \\
MM A-3 & Lower aquifer \\
MM C-3 & Upper Kirkwood - confining layer
\end{tabular}

Figure 24. Hydrogeologic section $C$ - $C^{\prime}$, Morses Mill Stream study area and vicinity, New Jersey Pinelands. (Line of section shown on figure 21.) 


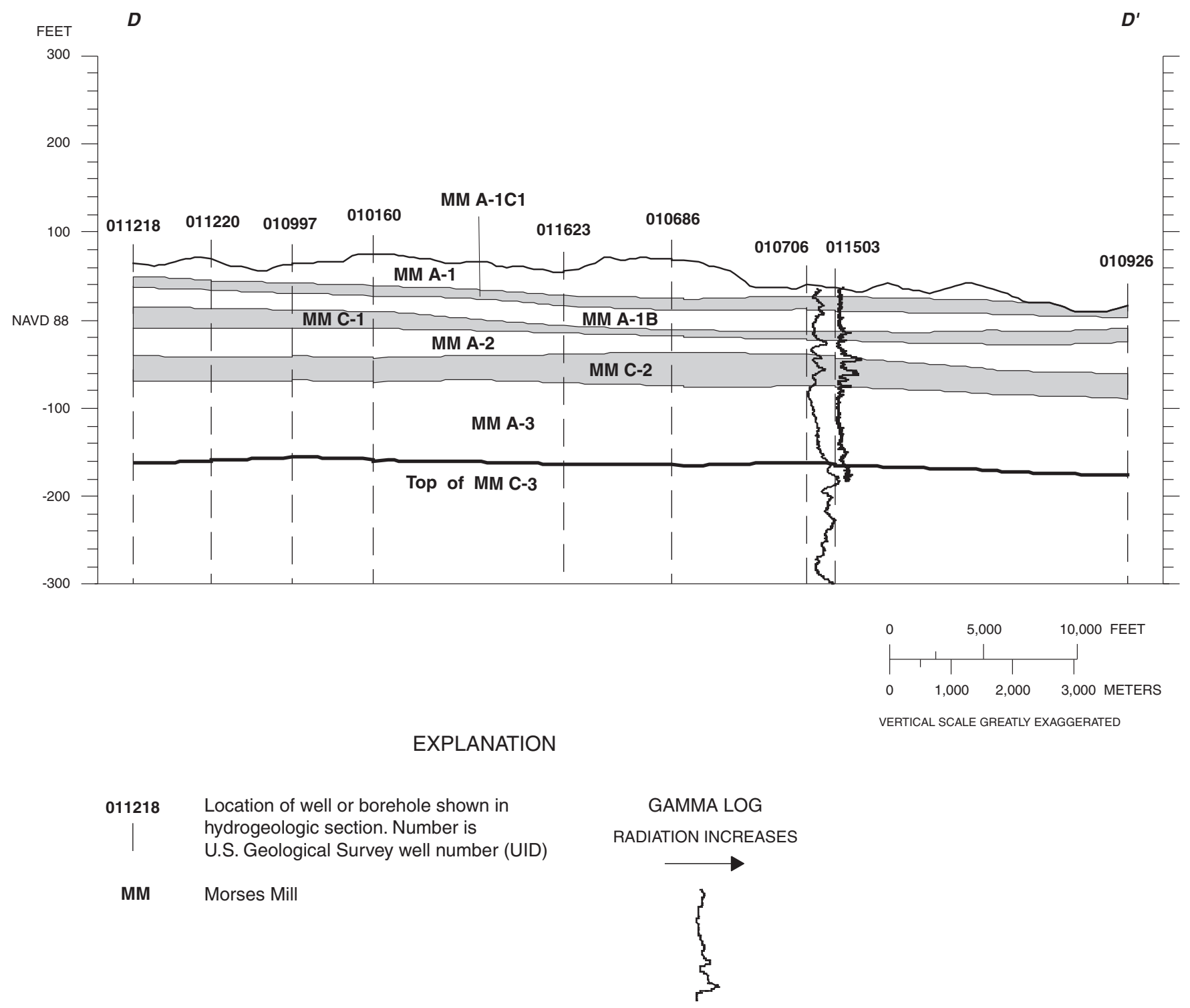

Hydrogeologic framework of the Kirkwood-Cohansey aquifer system in the Morses Mill study area.

\begin{tabular}{ll} 
Layer & Description \\
\cline { 2 - 2 } MM A-1 & Upper aquifer - upper layer \\
MM A-1C1 & Upper leaky - confining layer \\
MM A-1B & Upper aquifer - lower layer \\
MM C-1 & Middle leaky - confining layer \\
MM A-2 & Middle aquifer \\
MM C-2 & Lower leaky - confining layer \\
MM A-3 & Lower aquifer \\
MM C-3 & Upper Kirkwood - confining layer
\end{tabular}

Figure 25. Hydrogeologic section $D-D^{\prime}$, Morses Mill Stream study area and vicinity, New Jersey Pinelands. (Line of section shown on figure 21.) 


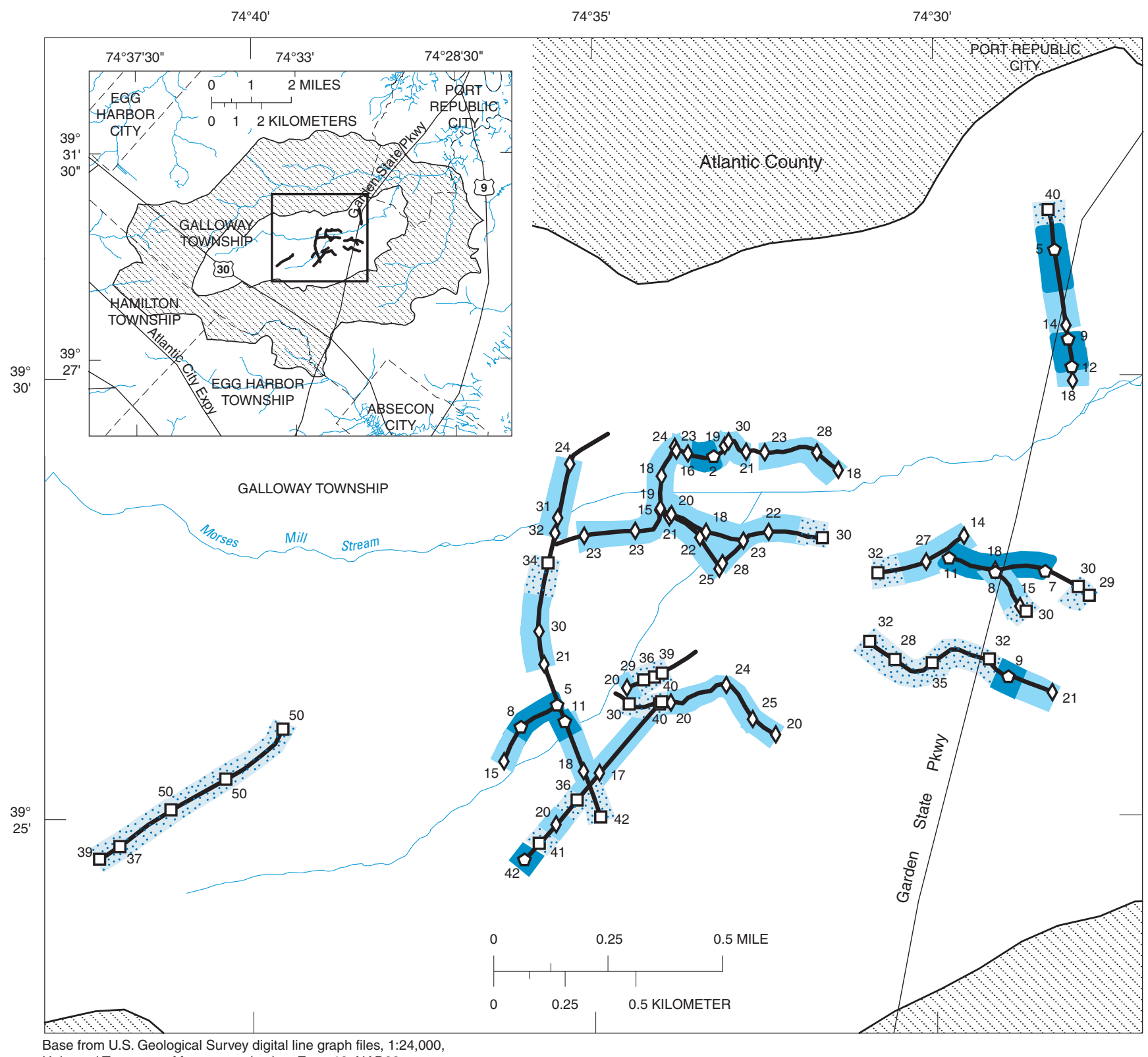

gital line graph files, 1:24,000

Universal Transverse Mercator projection, Zone 18, NAD83

\section{EXPLANATION}

Estimated extent of clay along GPR survey lines

$\because \because$ MM A-1 aquifer layer

MM A-1B aquifer layer

MM A-1C1 leaky confining layer

Morses Mill stream study area

Ground penetrating radar survey line

Morses Mill stream drainage basin
$32 \square$ Clay identified in the MM A-1 aquifer layer. Number is altitude of top of clay layer, in feet. Datum is NAVD 88

8 Clay identified in the MM A-1B aquifer layer. Number is altitude of top of clay layer, in feet. Datum is NAVD 88

$20 \diamond$ Clay identified in the MM A-1C1 leaky confining layer. Number is altitude of top of clay layer, in feet. Datum is NAVD 88

Figure 26. Results of ground-penetrating radar (GPR) surveys used to describe the hydrogeologic framework of the Morses Mill Stream study area and vicinity, New Jersey Pinelands. 


\section{Summary and Conclusions}

The New Jersey Pinelands area (Pinelands) is a 1.1million-acre natural reserve area in southern New Jersey that overlies the Kirkwood-Cohansey aquifer system in the Atlantic Coastal Plain. This ecologically diverse area supports a variety of habitats and is home to many threatened and endangered species. Cedar swamps, pine and oak forests, agricultural areas, and planned development dominate the landscape. Demand for water from the Kirkwood-Cohansey aquifer system is increasing as development within the area increases.

To assess the effects of ground-water withdrawals from the Kirkwood-Cohansey aquifer system on stream and wetland water levels, the U.S. Geological Survey (USGS), in cooperation with the New Jersey Pinelands Commission, began a multi-phase hydrologic investigation in 2004 to characterize the hydrologic system that supports the Pinelands aquatic and wetland communities.

The Albertson Brook, McDonalds Branch, and the Morses Mill Stream drainage basins (study areas) were selected for detailed hydrologic assessment to provide the information needed to develop ground-water flow models that can predict the response of the aquifer system to increased ground-water withdrawals. The first phase of this assessment and the subject of this report is a comprehensive hydrogeologic investigation. During 2004-05, a database of hydrogeologic information was compiled, and a conceptual hydrogeologic framework model was prepared for each of the three study areas. Existing geophysical and lithologic data were assessed and new borehole geophysical data were obtained during the drilling of 21 new wells and one deep borehole within the three study areas. These data were added to the database and integrated into the analysis. In addition, surface geophysical data acquired using ground-penetrating radar (GPR) along more than $27 \mathrm{mi}$ were analyzed for the three study areas. Five additional wells installed in upland areas of the McDonalds Branch basin provided shallow lithologic data. Ten shallow boreholes were completed, providing lithologic ground truth for analyzing the GPR records. The assessments of the shallow lithologic data were added to the analysis, and the hydrogeologic framework models were finalized.

The hydrogeologic framework models, developed in preparation for the construction of a ground-water flow model of each study area, subdivided the Kirkwood-Cohansey aquifer system described by Zapecza (1989) into seven layers, characterized by their predominant sediment textures, as aquifers or leaky confining layers. The hydrogeologic framework of each study area is represented by a model containing four aquifer layers, separated by three leaky confining layers, and a basal confining layer. The three hydrogeologic framework models are similar, but they are distinctly separate; each one is unique to a particular study area. Hydrogeologic sections, maps of structure tops, and thickness maps were produced for each study area model to show differences in sediment textures within each model layer; the sections and maps are based on geophysical and lithologic data. The key findings of this study area are listed below.

- The hydrogeology of the three study areas is similar even though the sediment textures may vary throughout the Kirkwood-Cohansey aquifer system.

- The leaky confining layers are more closely spaced and the presence of discontinuous clays is generally more common in the upper part of the aquifer system, which is principally represented by the Cohansey Sand and younger surficial deposits.

- With the exception of the basal clay confining layers, the variable and discontinuous nature of clay layers within the Kirkwood-Cohansey aquifer system was confirmed by the geophysical and lithologic records.

- Results of the investigation indicate considerable variability in the presence of different sediment textures; the extent to which this hydrogeologic variability can be characterized is constrained by the extent of the available geologic and lithologic data.

- Although the Kirkwood-Cohansey aquifer system has been considered a water-table aquifer in many areas, localized clays in the aquifers and leaky confining layers may act to impede the flow of ground water.

- In the Albertson Brook and McDonalds Branch study areas, sediment textures are typically coarser in the upper $100 \mathrm{ft}$ of the aquifer system than was observed in the Morses Mill Stream study area.

- In the Albertson Brook and Morses Mill Stream study areas, sediments of layers AB A-3 Lower aquifer and MM A-3 Lower aquifer, respectively, tend to show increasing homogeneity as they dip and thicken toward the southeast. In contrast, the MB A-3 Lower aquifer in the McDonalds Branch does not thicken substantially within the study area, does contain clays, and does exhibit a thicker gradational interval approaching the base of the aquifer system.

- The base of the Kirkwood-Cohansey aquifer system for this study is generally represented by one of the two basal clay confining beds identified by Zapecza (1989).

- The regionally extensive basal clay in the lower part of the Kirkwood Formation is common to both the Albertson Brook and McDonalds Branch study areas and is the only layer of the models that can be correlated between the study areas.

- The base of the aquifer system in the vicinity of the Morses Mill Stream study area is the thick diatomaceous clay in the upper part of the Kirkwood Formation. 
- The deeper hydrogeologic framework layers tend to dip to the southeast and generally conform to the slope of the top of the basal clays. The dip of the overlying layers appears to decrease slightly where the layers are closer to the land surface. The tops of the shallower layers generally follow the slope of the drainage basins, reflecting a closer relation to the erosion-incised valleys that form the basins.

The estimated mean horizontal hydraulic conductivity (K) values determined from various well tests in the the three study areas ranged from 84 to 130 feet/day. The estimated $\mathrm{K}$ values from well tests are consistent with those reported by other investigators for the Kirkwood-Cohansey aquifer system.

\section{Acknowledgments}

The authors gratefully acknowledge the local and State officials who provided assistance in identifying and accessing well drilling locations in Winslow Township in Camden County; Brenden Byrne State Forest in Burlington County; Wharton State Forest in Atlantic, Burlington, and Camden Counties; and Richard Stockton College in Atlantic County and for collection of surface-geophysical data. The authors wish to thank their USGS colleagues Christine Wieben, Donald Storck, Gregory Simpson, William Ellis, Ruth Larkins, Donald Rice, Steven Tessler, Nicholas Smith, Robert Rosman, Lawrence Feinson and Timothy Reilly for technical advice; help with well installation, slug tests, and analysis; report preparation, illustrations, and editing; database construction; and data validation. Lloyd Mullikin of the New Jersey Geological Survey provided numerous geophysical logs and well and borehole logs, as did representatives of the U.S. Environmental Protection Agency who arranged access to geophysical logs, well logs, and records for sites. The authors also thank the reviewers of this report Dr. Allison Brown of the New Jersey Pinelands Commission and Robert Nicholson, Emmanuel Charles, and Ronald Sloto of the USGS for insights and comments that greatly improved the quality of this report.

\section{References Cited}

Anderson, H.R., Appel, C. A., 1969, Geology and groundwater resources of Ocean County, New Jersey: New Jersey Dept. of Conservation and Economic Development, Division of Water Policy and Supply Special Report 29, 93 p.

Barksdale, H.C., Geenman, D.W., Lang, S.M., Hilton, G.S., and Outlaw, D.E., 1958, The ground-water resources in the tri-county region adjacent to the lower Delaware River: New Jersey Dept. of Conservation and Economic Development Special Report 13, 190 p.
Bouwer, Herman, and Rice, R.C., 1976, A slug test for determining hydraulic conductivity of unconfined aquifers with completely or partially penetrating wells: Water Resources Research, v.12, no.3, p. 423-428.

Butler, J.J., Jr., 1998, The design, performance, and analysis of slug tests: Boca Raton, Florida, Lewis Publishers, 252 p.

Carter, C.H., 1978, A regressive barrier and barrier-protected deposit: Depositional environments and geographic setting of the late Tertiary Cohansey Sand: Journal of Sedimentary Petrology, v.48, no.3, p. 933-950.

Farlekas, G.M., Nemickas, Bronius, and Gill, H.E., 1976, Geology and ground-water resources of Camden County, New Jersey: U.S. Geological Survey Water-Resources Investigations 76-76, $146 \mathrm{p}$.

Freeze, R.A., and Cherry, J.A., 1979, Groundwater: Englewood Cliffs, New Jersey, Prentice Hall, Inc., 604 p.

Gill, H. E., and Farlekas, G.M., 1976 Geohydrologic maps of the Potomac-Raritan-Magothy aquifer system in the New Jersey Coastal plain: U.S. Geological Survey Hydrologic Investigations Atlas HA-557.

Greene, E.A., and Shapiro, A.M., 1995, Methods of conduction air-pressurized slug tests and computation of type curves for estimating transmissivity and storativity: U.S. Geological Survey Open-File Report 95-424, 43 p.

Hardt, W. F., Hilton, G.S., 1969, Water resources and geology of Gloucester County, New Jersey: New Jersey Dept. of Conservation and Economic Development, Division of Water Policy and Supply Special Report 30, 130 p.

Hvorslev, M.J., 1951, Time lag and soil permeability in ground-water observations: Vicksburg, Miss., U.S. Army Corps of Engineers Waterways Experiment Station Bulletin $36,50 \mathrm{p}$.

Johnson, J.H., 1978, Soil Survey of Atlantic County, New Jersey: U.S. Soil Conservation Service, 60 p., 51, maps.

Johnsson, P.A., and Barringer, J.L., 1993, Water quality and hydrogeochemical processes in McDonalds Branch basin, New Jersey Pinelands, 1984-88: U.S. Geological Survey Water-Resources Investigations Report 91-4081, 111 p.

Keys, W.S., 1987, Borehole geophysics applied to groundwater investigations: U.S. Geological Survey Techniques of Water-Resources Investigations, book 2, chap. E2, 149 p.

Lohman, S.W., 1972, Ground-water hydraulics: U.S. Geological Survey Professional Paper 708, 70 p., 9 pl. 
Lord, D.G., Barringer, J.L., Johnsson, P.A., Schuster, P.F., Walker, R.L., Fairchild, J.E., Sroka, B.N., and Jacoben, Eric, 1990, Hydrogeochemical data from an acidic deposition study at McDonalds Branch basin in the New Jersey Pinelands, 1983-86: U.S. Geological Survey Open-file Report 88-500, 132 p.

MALÅ GeoScience, 2003, RAMAC GroundVision GPR Measurement Software, Version 1.4.1: Sweden (Available from http://www.malags.com).

Markley, M.L., 1965, Soil survey of Camden County, New Jersey: U.S. Soil Conservation Service, 94 p., 33 maps.

Markley, M.L., 1971, Soil survey of Burlington County, New Jersey: Washington D.C., U.S. Department of Agriculture, Cartographic Division, Soil Conservation Service, 103 p.

Macbeth Division of Kollmorgen Instruments Corporation, 1975, Munsell Soil Color Charts: New Windsor, N.Y.

Newell, W.L, Powars, D.S., Owens, J.P., Stanford, S.D., and Stone, B.D., 2000, Surficial geologic map of central and southern New Jersey: U.S. Geological Survey Miscellaneous Investigations Series Map I-2540-D, p. 1-19, 3 sheets.

New Jersey Pinelands Commission, 2003, The KirkwoodCohansey project work plan, accessed at http://www.state. nj.us/pinelands/Kirkwood-Cohansey\%20Project $\% 20$ Work\%20Plan.pdf

New Jersey Pinelands Commission, 1981, Comprehensive Management Plan, (periodically updated) accessed May 15, 2006, at http://www.state.nj.us/pinelands/cmp/summary.

Rhodehamel, E.C., 1973, Geology and water resources of the Wharton Tract and the Mullica River Basin in southern New Jersey: New Jersey Department of Environmental Protection, Special Report Number 36, 58 p.

Rhodehamel, E.C., 1979, Geology of the Pine Barrens of New Jersey, in Forman, R.T.T., ed., Pine Barrens: ecosystem and landscape: New York, Academic Press, p. 39-60.

Rush, F.E., 1968 Geology and ground-water resources of Burlington County, New Jersey: New Jersey Department of Conservation and Economic Development, Division of Water Policy and Supply Special Report 26, 65 p.

Springer, R.K., and Gelhar, L.W., 1991, Characterization of large-scale aquifer heterogeneity in glacial outwash by analysis of slug tests with oscillatory responses, Cape Cod, Massachusetts, in U.S. Geological Survey Toxic Substances Hydrology Program-Proceedings of the technical meeting, Monterey, California, March 11-15, 1991: U.S. Geological Survey Water-Resources Investigations Report 91-4034, $730 \mathrm{p}$.
U.S. Department of Agriculture, Natural Resources Conservation Service (NRCS), 2000, Hydric soils criteria, accessed June 20, 2006, at http://soils.usda.gov/use/hydric/criteria. html

Walton, W.C., 1970, Groundwater Resource Evaluation: New York, McGraw-Hill Book Company, 664 p.

Zapecza, O.S., 1989, Hydrogeologic framework of the New Jersey Coastal Plain: U.S. Geological Survey Professional Paper 1404-B, 49 p., 24 pl.

Zapecza, O.S., Voronin, L.M., and Martin, Mary, 1987, Ground-water-withdrawal and water-level data used to simulate regional flow in the major Coastal Plain aquifers of New Jersey: U.S. Geological Survey Water-Resources Investigations Report 87-4038, 120 p. 


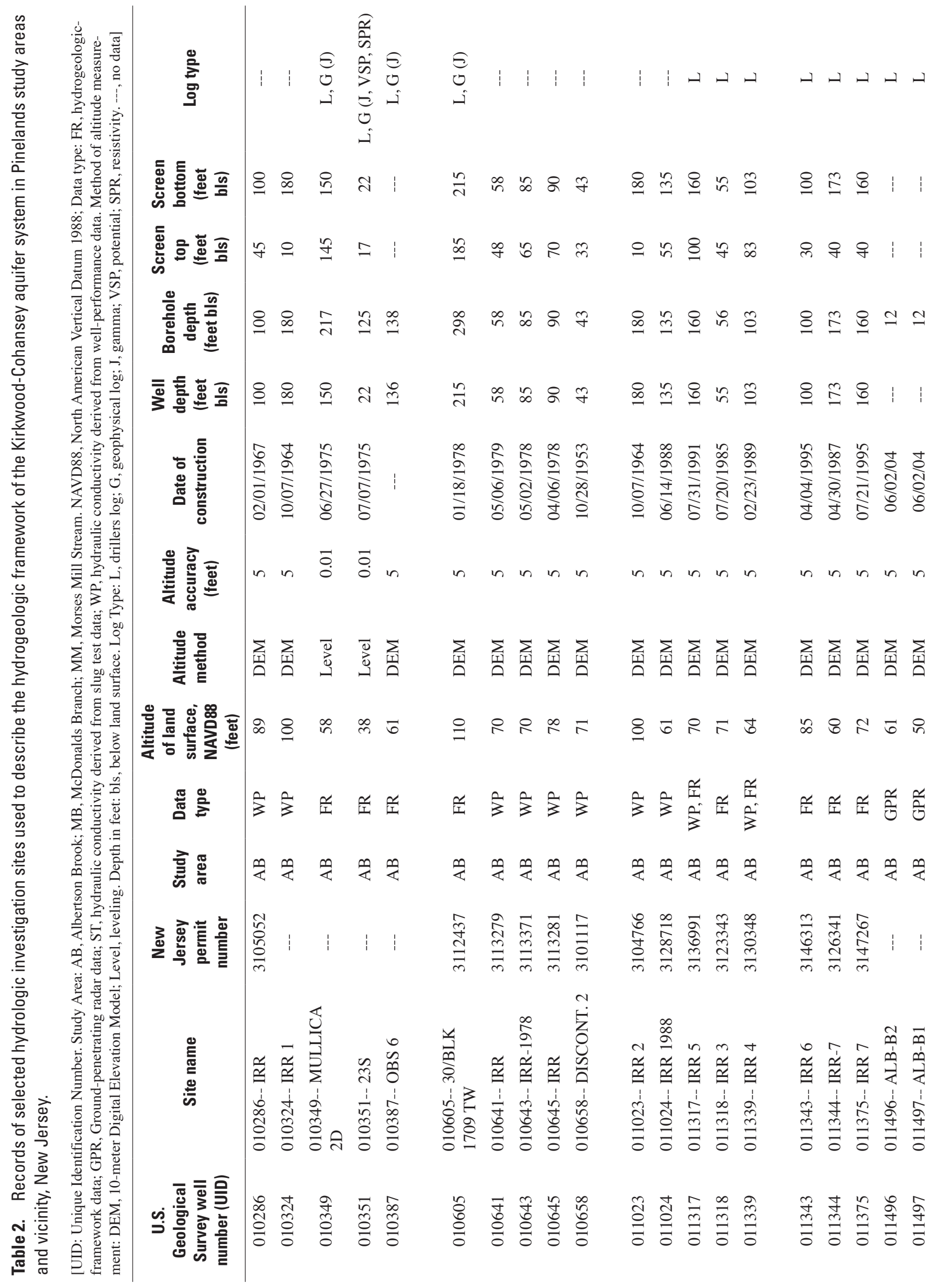




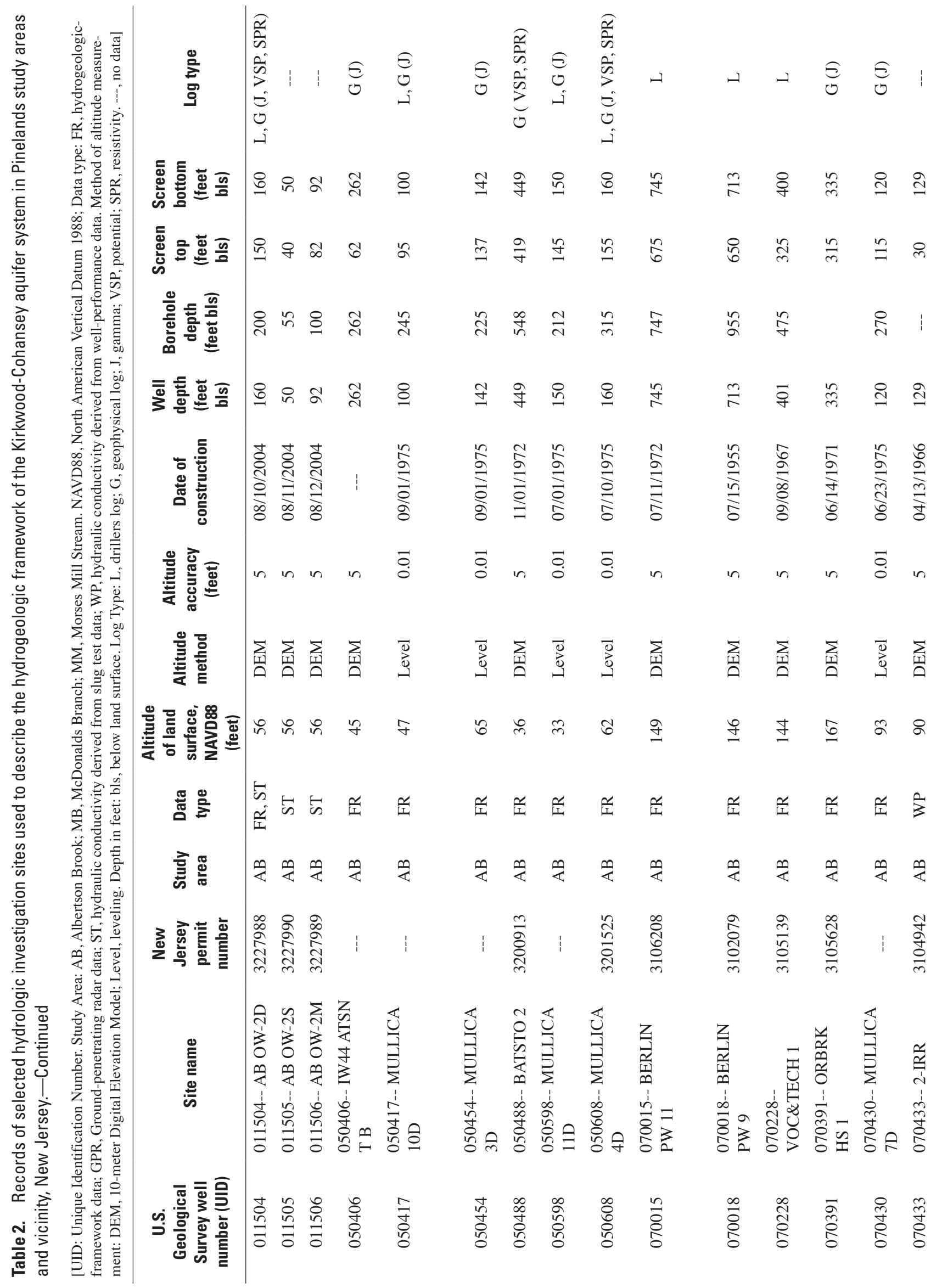




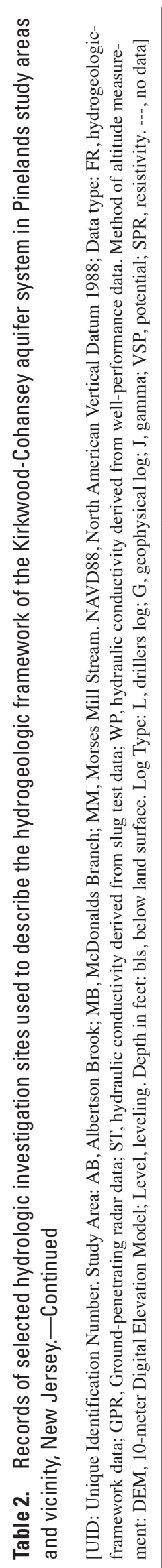

\begin{tabular}{|c|c|c|c|c|}
\hline 5 & $11: 1$ & 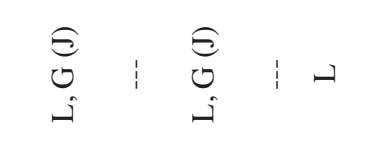 & $1: 1+1$ & I \\
\hline & 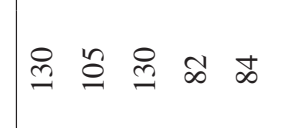 & 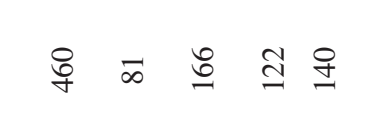 & 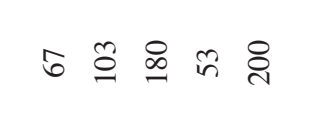 & 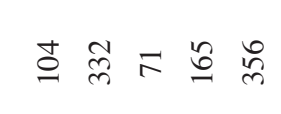 \\
\hline & 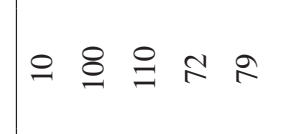 & $q=\Phi \varnothing$ & 的去东质有 & $\therefore \stackrel{c}{\circ}$ \\
\hline & $1 \quad 1 \quad 1 \quad 1 \quad+\infty$ & 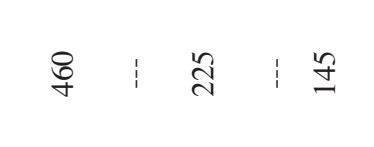 & $|:| \vec{c} \mid$ & $:$ \\
\hline & $\oslash$. & 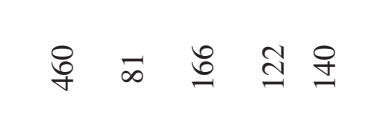 & 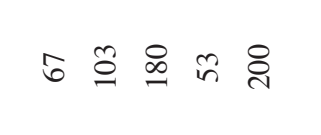 & 声紫: \\
\hline & 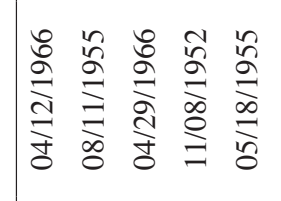 & 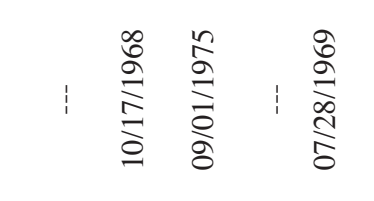 & 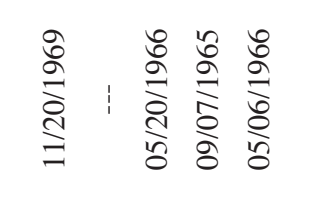 & 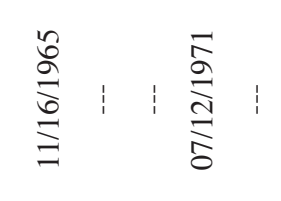 \\
\hline & nornon & $n n \bar{\partial} \dot{\partial} n$ & non mon & $n n$ \\
\hline & 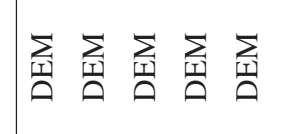 & 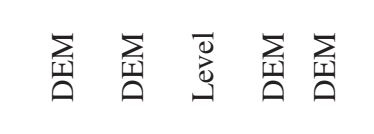 & 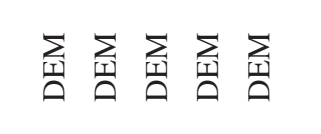 & 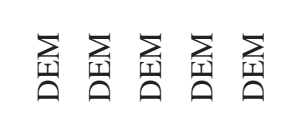 \\
\hline & $\vec{\sigma} \sigma \stackrel{\infty}{=} \stackrel{\infty}{=} \stackrel{\infty}{\stackrel{\infty}{0}}$ & 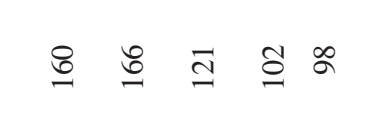 & 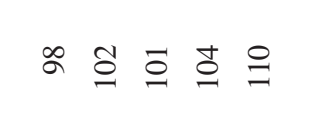 & 20 \\
\hline & $\hat{\equiv} \equiv$ & 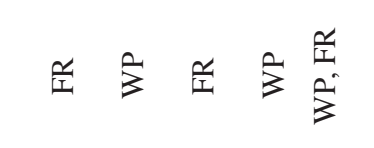 & 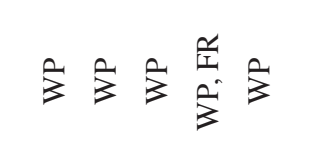 & \\
\hline & 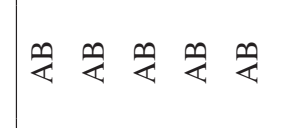 & 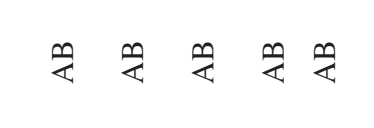 & 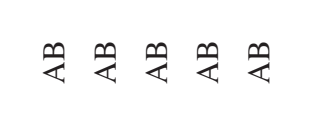 & 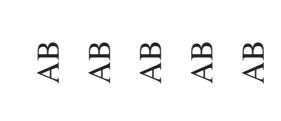 \\
\hline & & 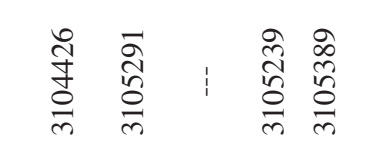 & $1: \frac{9}{0}$ & 善善 \\
\hline & 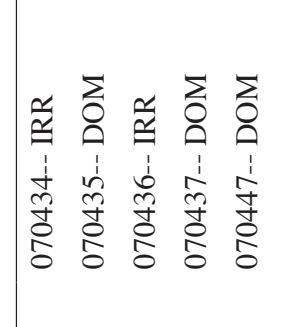 & 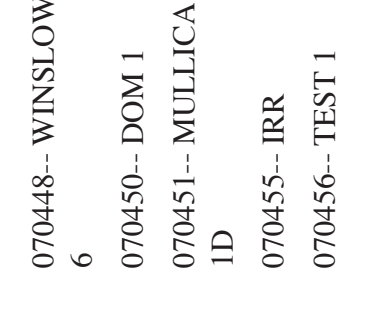 & 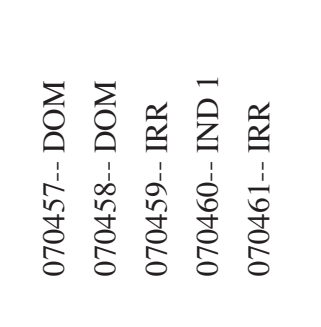 & 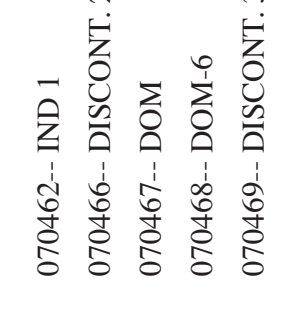 \\
\hline & & 释号 & & \\
\hline
\end{tabular}




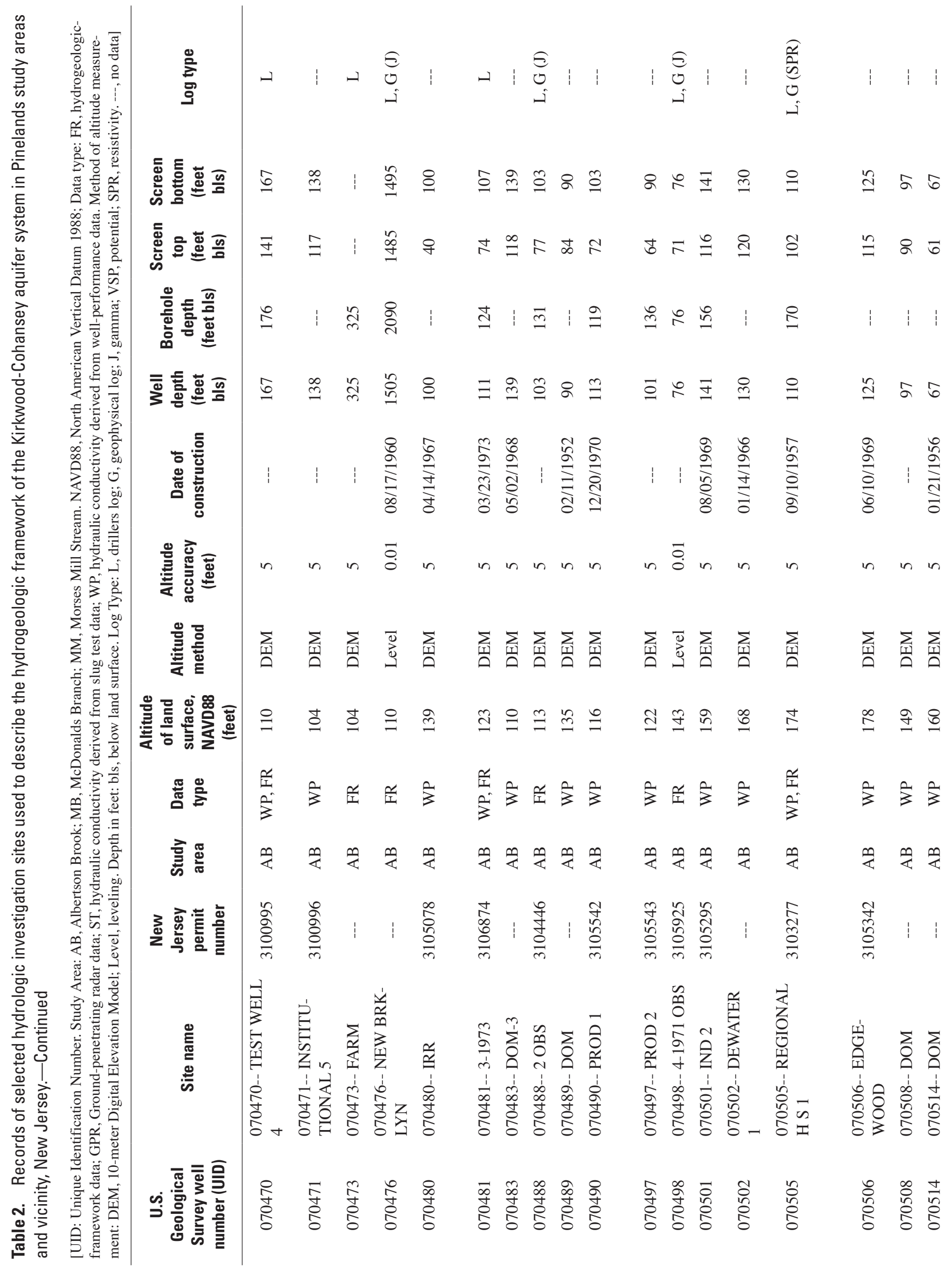




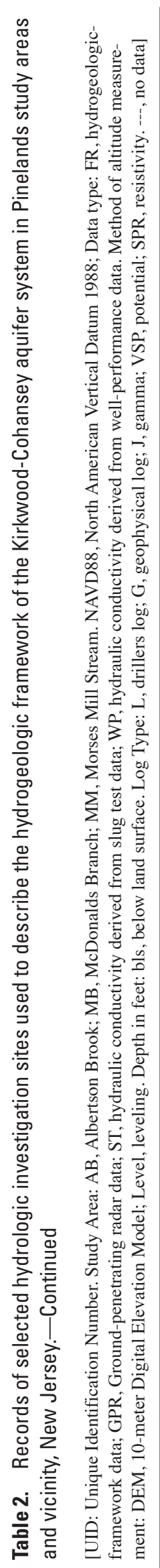

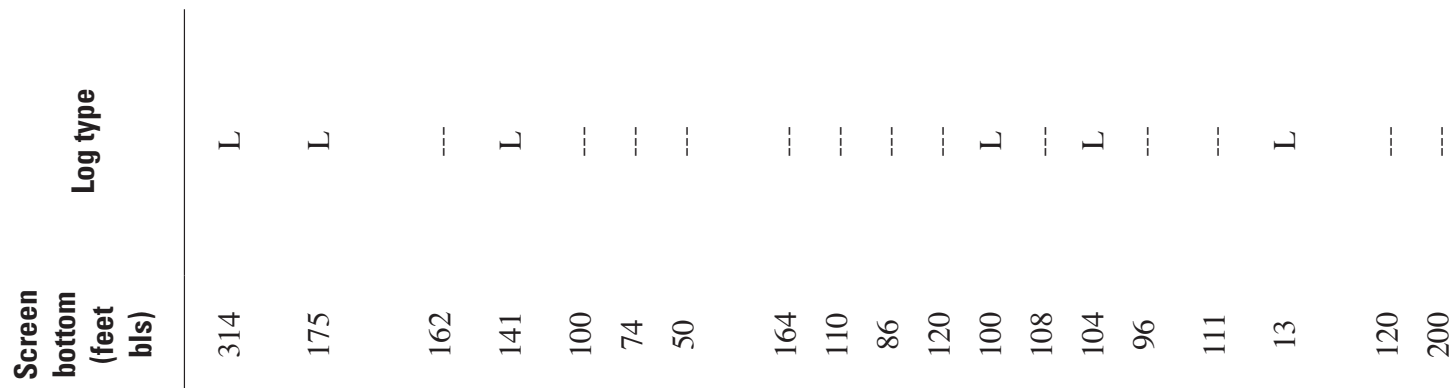

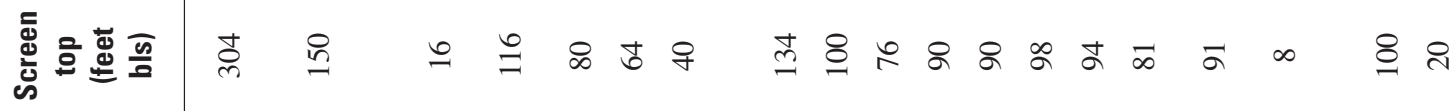
高言票

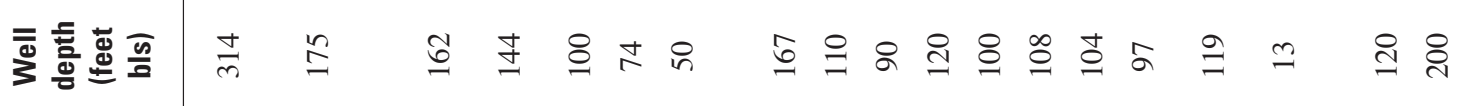

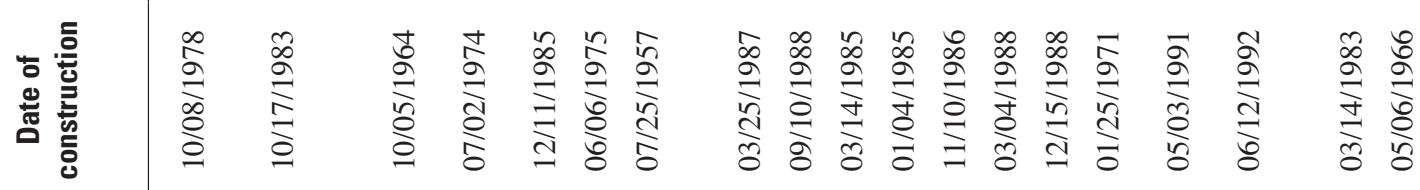

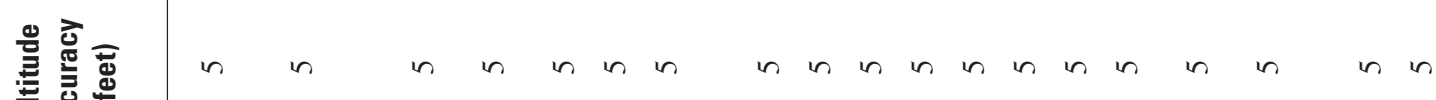

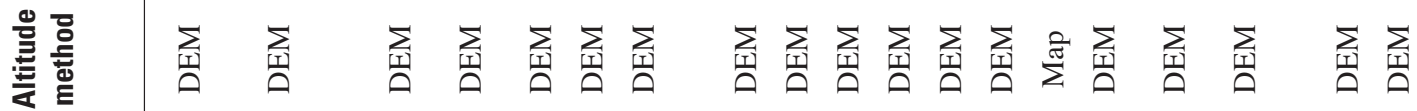

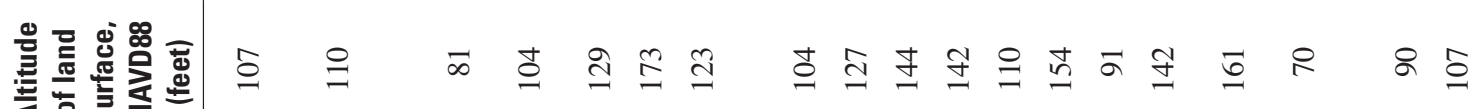

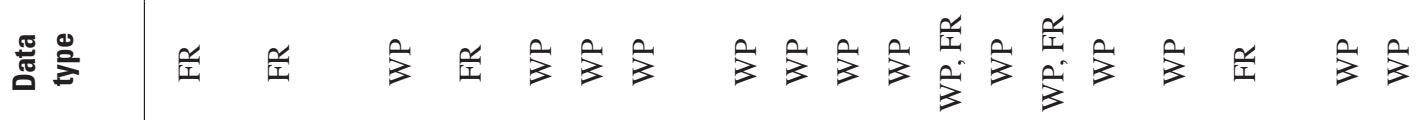
言管

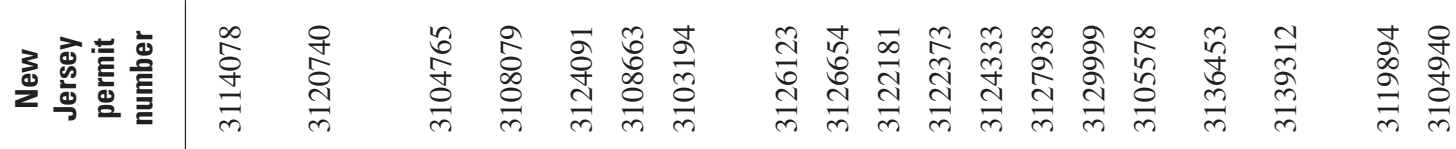

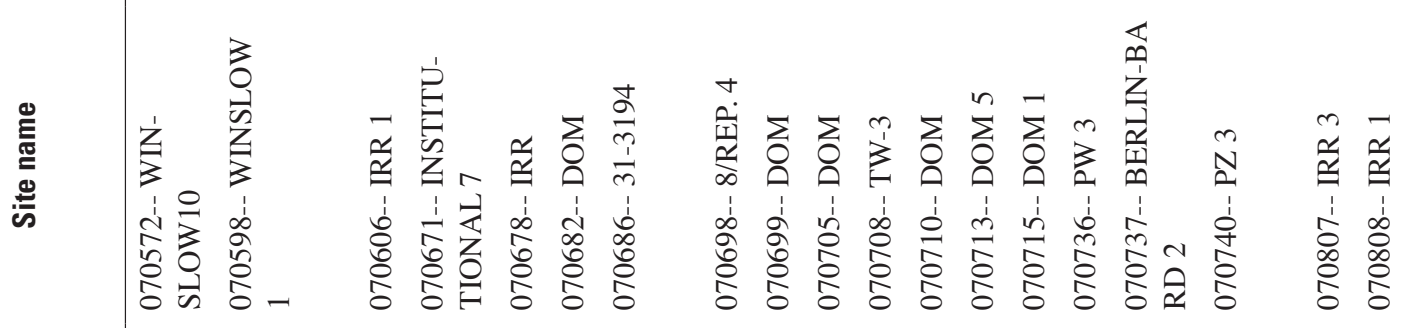

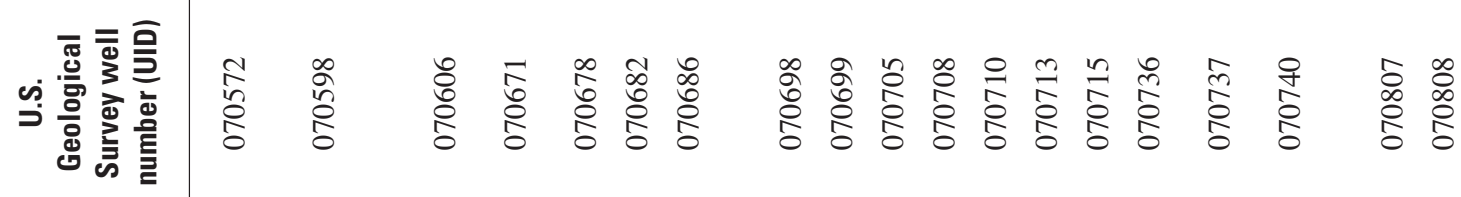




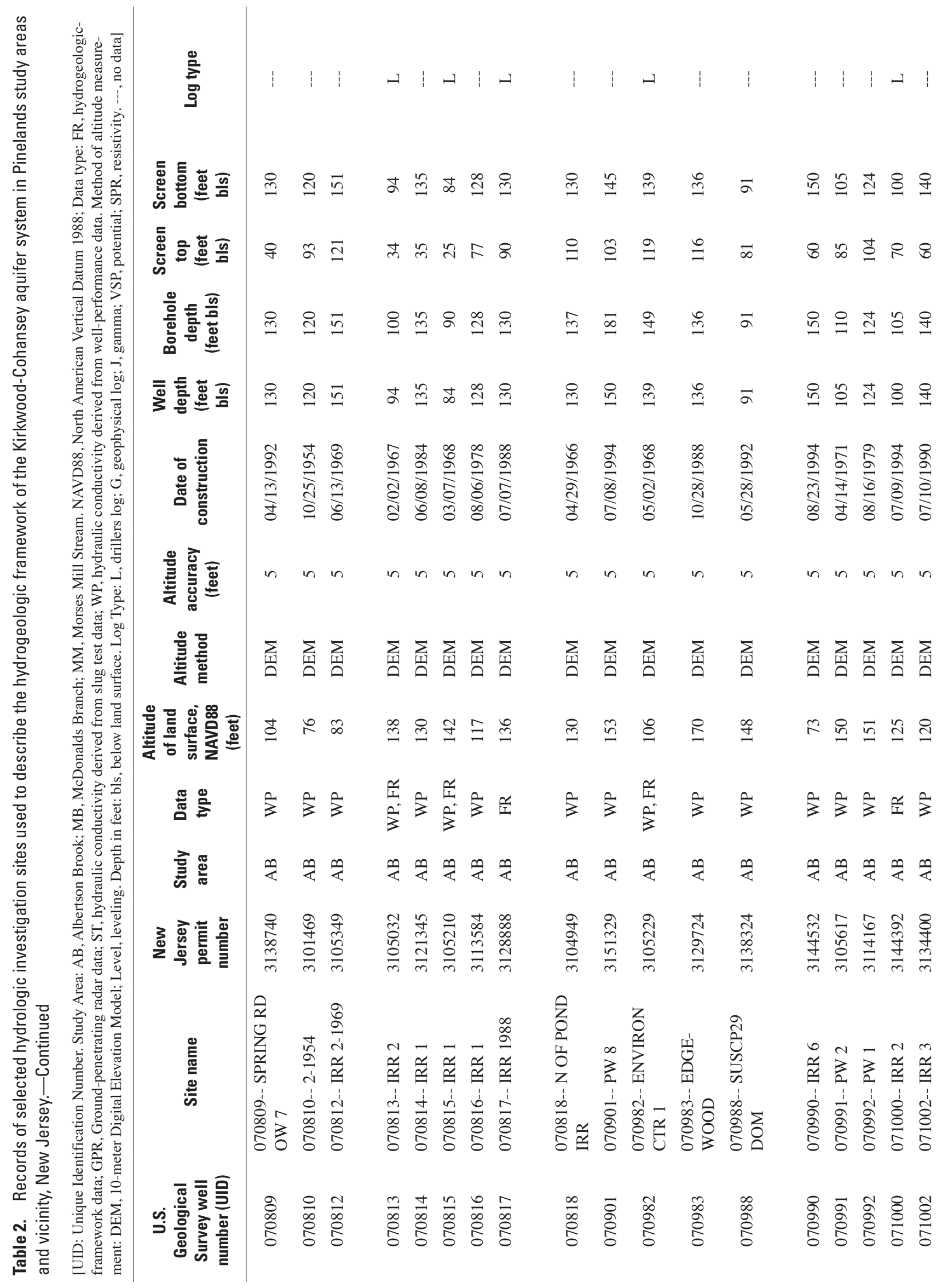




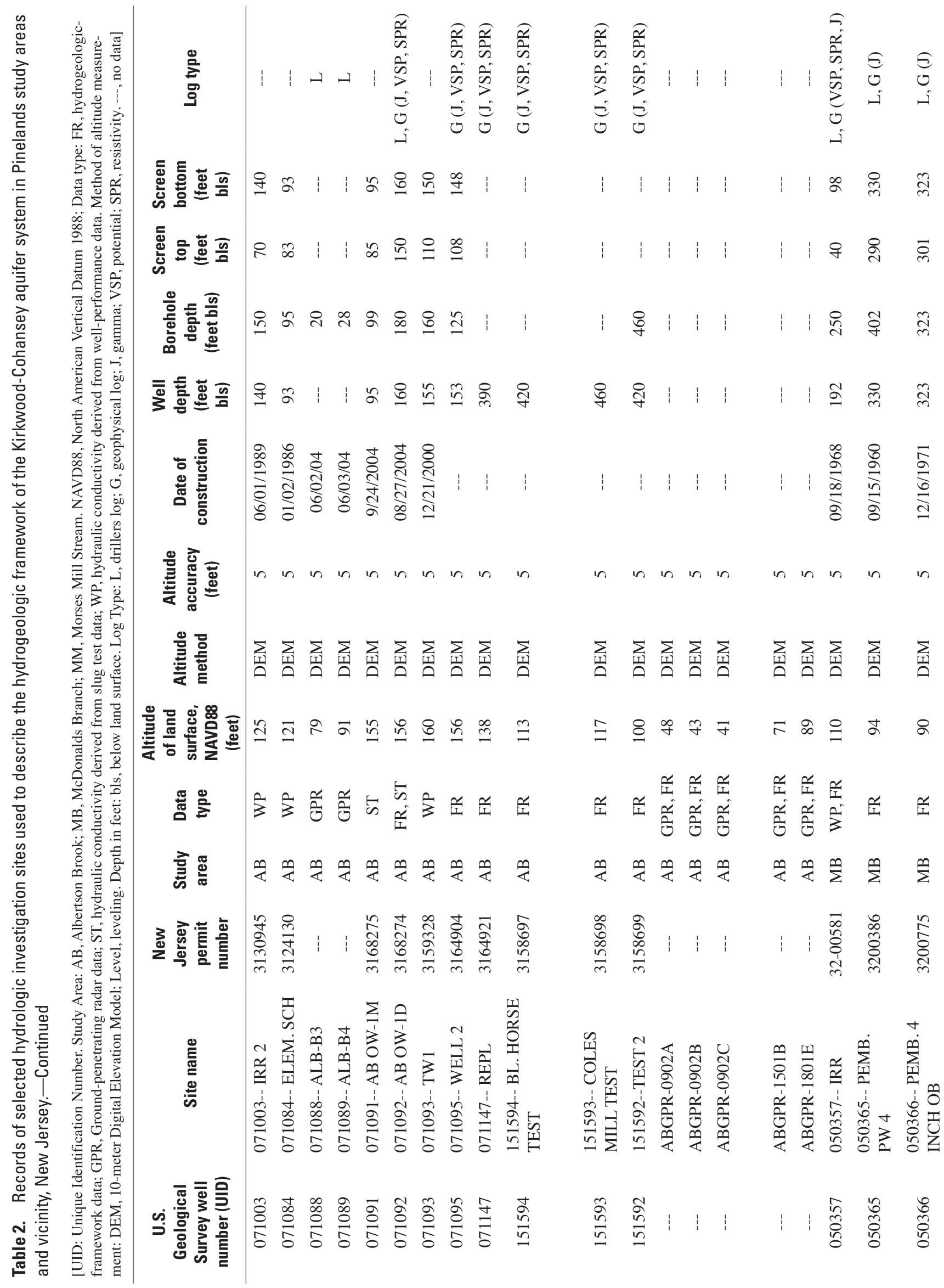




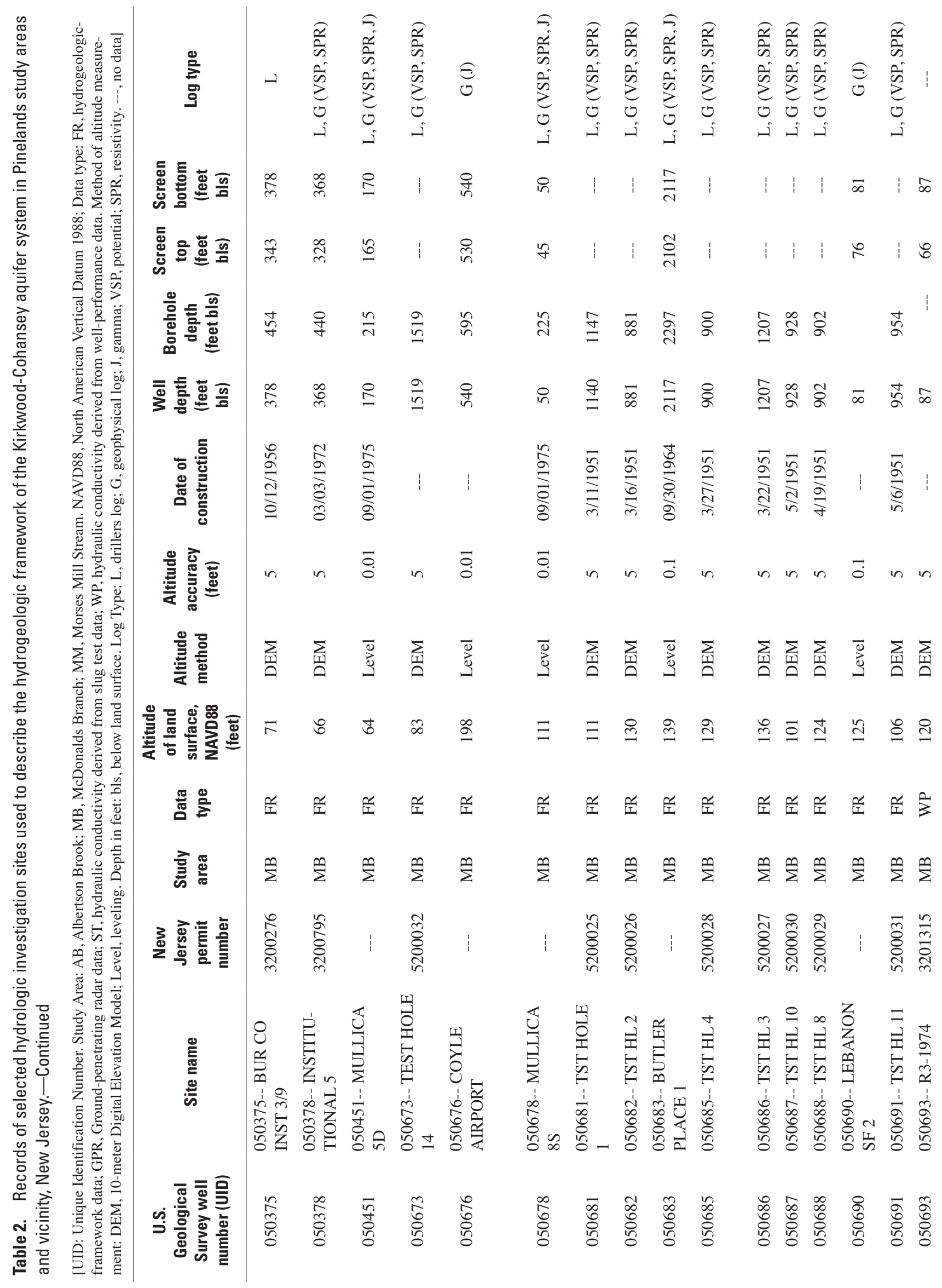




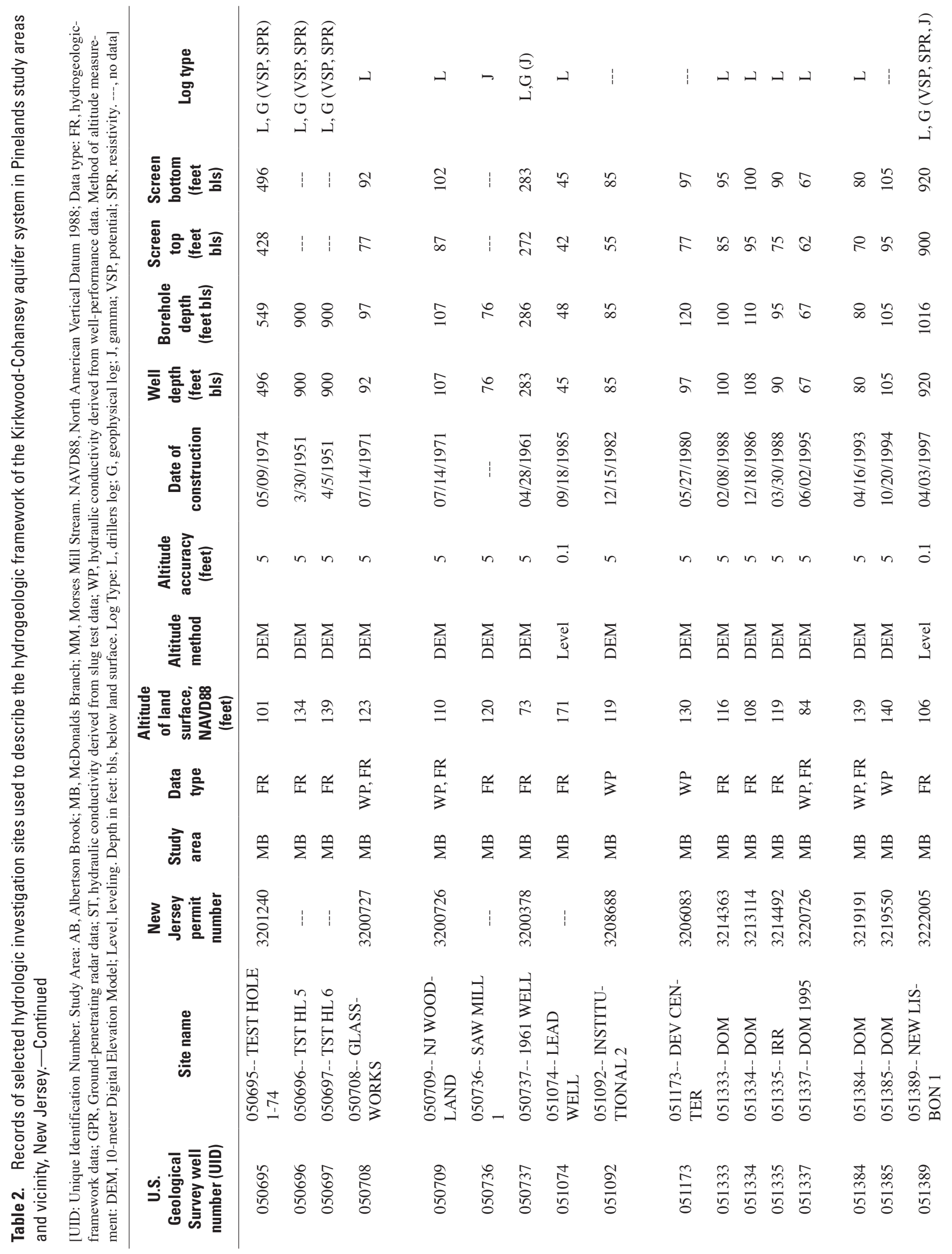




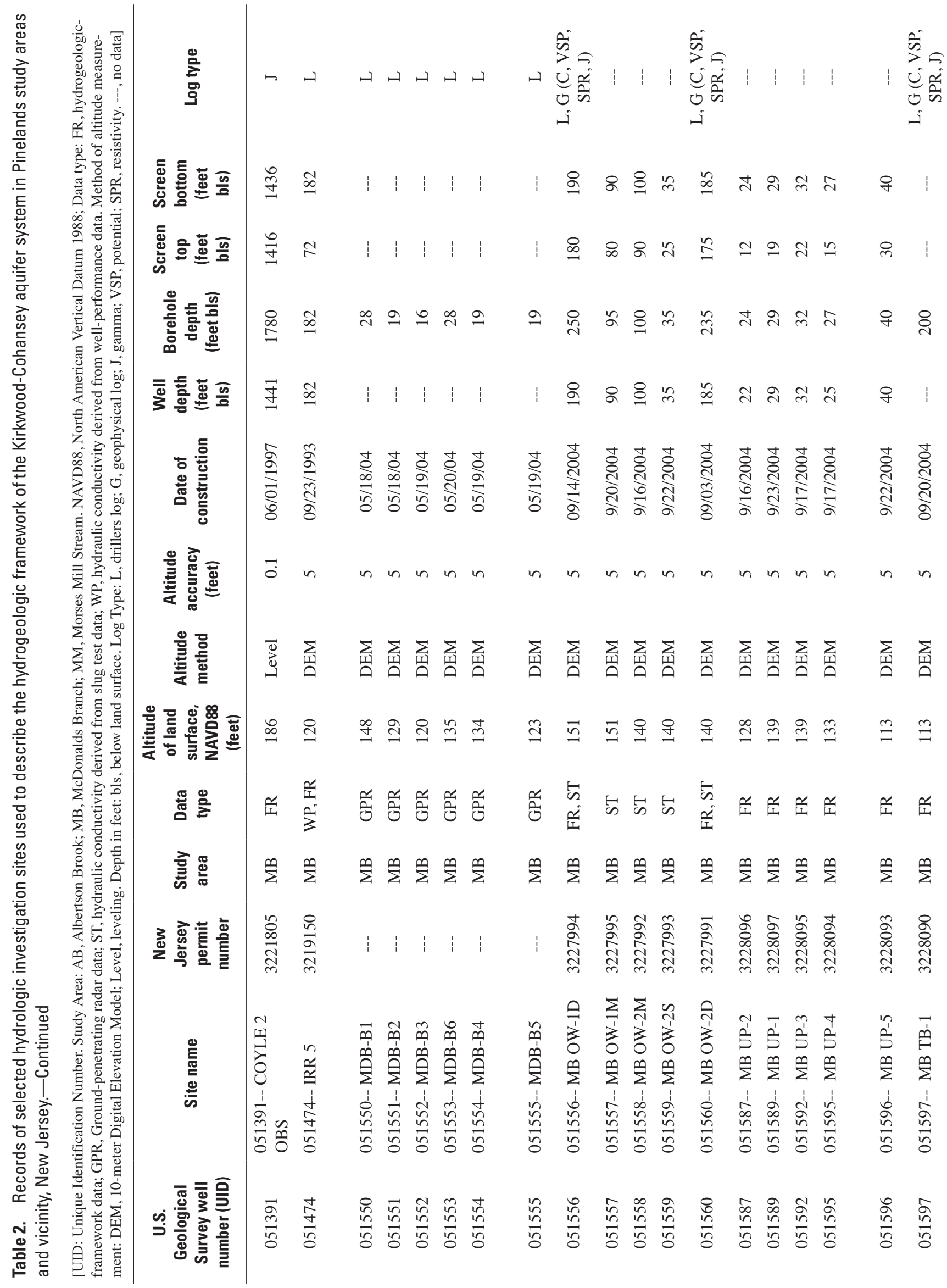




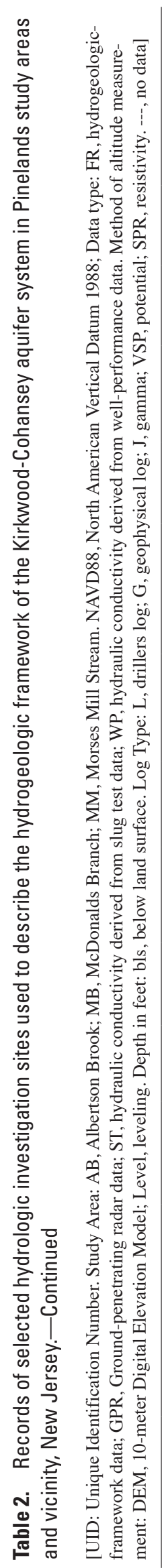

\begin{tabular}{|c|c|c|c|c|}
\hline 总 & 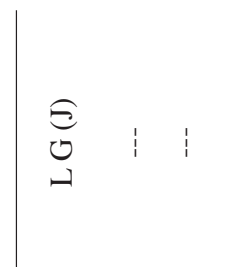 & $1: 1: 11$ & 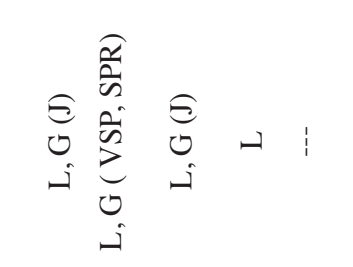 & 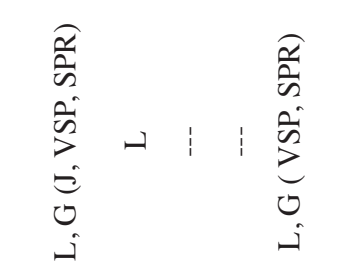 \\
\hline 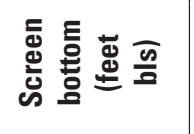 & $1: 1$ & $1: 1: 1: 1$ & 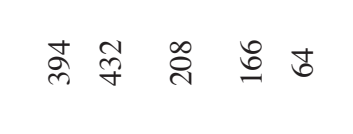 & 里 $\leqq \cong$ \\
\hline 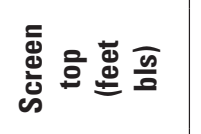 & $1: 1$ & $1: 1: 11$ & 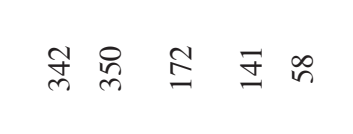 & $8 \equiv$ \\
\hline & $1: 1$ & $1: 111:$ & 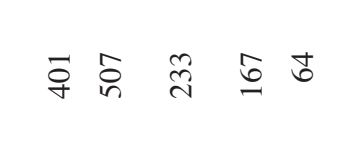 & ठำ \\
\hline & 必 : : & $1: 111$ & 可学究巨古 & 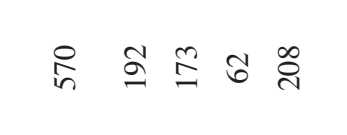 \\
\hline & $1: 1$ & $1: 1: 1:$ & 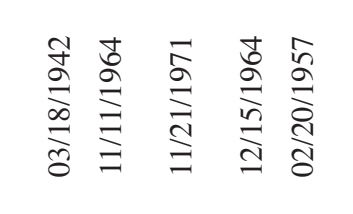 & 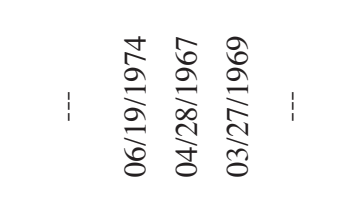 \\
\hline 承 & $\overrightarrow{0} n n$ & non mon & non $n$ n & 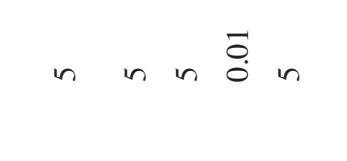 \\
\hline & 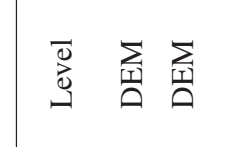 & 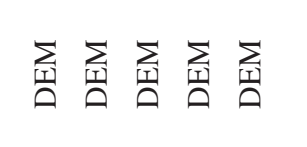 & 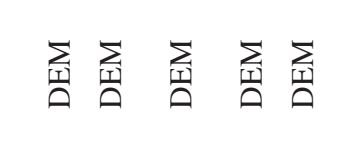 & 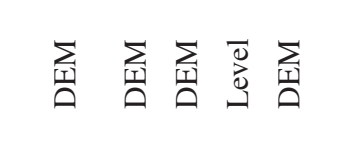 \\
\hline 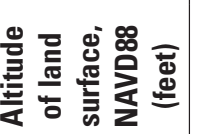 & $\cong 9$ & 成里守守员 & 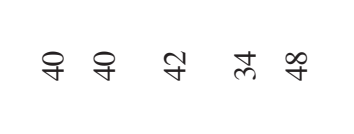 & 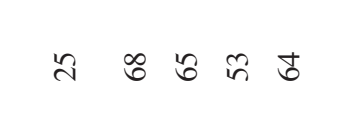 \\
\hline & 总送 & 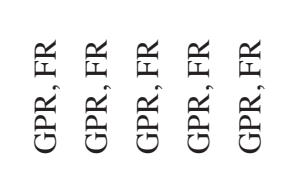 & 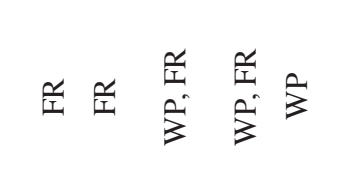 & 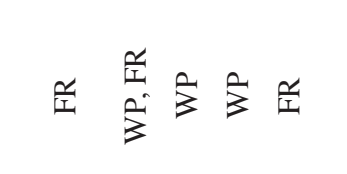 \\
\hline & $\frac{m}{2} \frac{m}{2} \frac{m}{2}$ & $\frac{m}{2} \frac{m}{2} \frac{m}{2} \frac{m}{2} \frac{m}{2}$ & 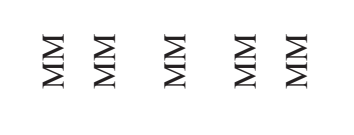 & 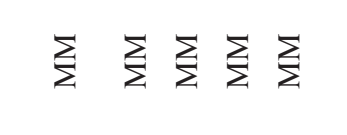 \\
\hline 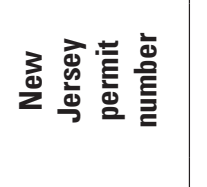 & $1: 1$ & $1: 111$ & 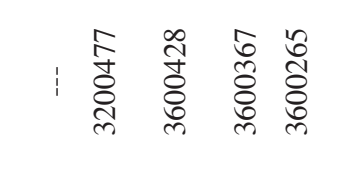 & 喜喜喜: 喜 \\
\hline 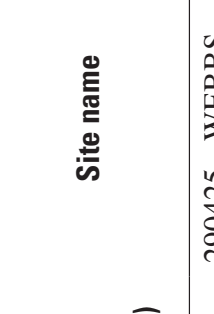 & 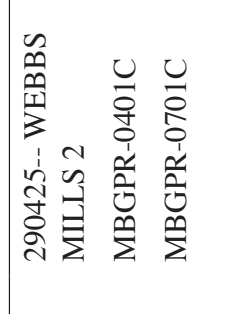 & 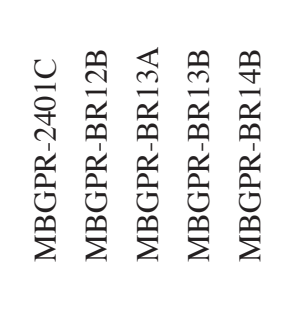 & 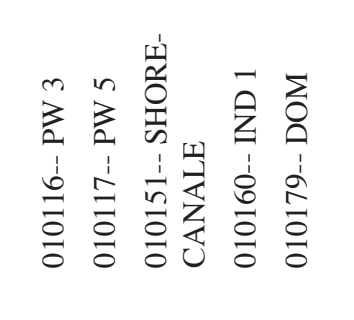 & 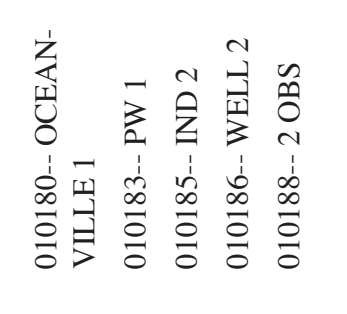 \\
\hline 3 & 翌: & $1: 1$ & 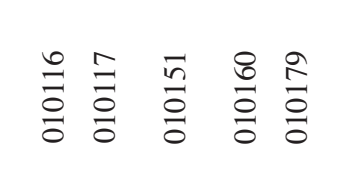 & 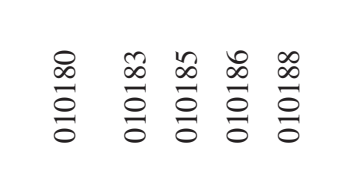 \\
\hline
\end{tabular}




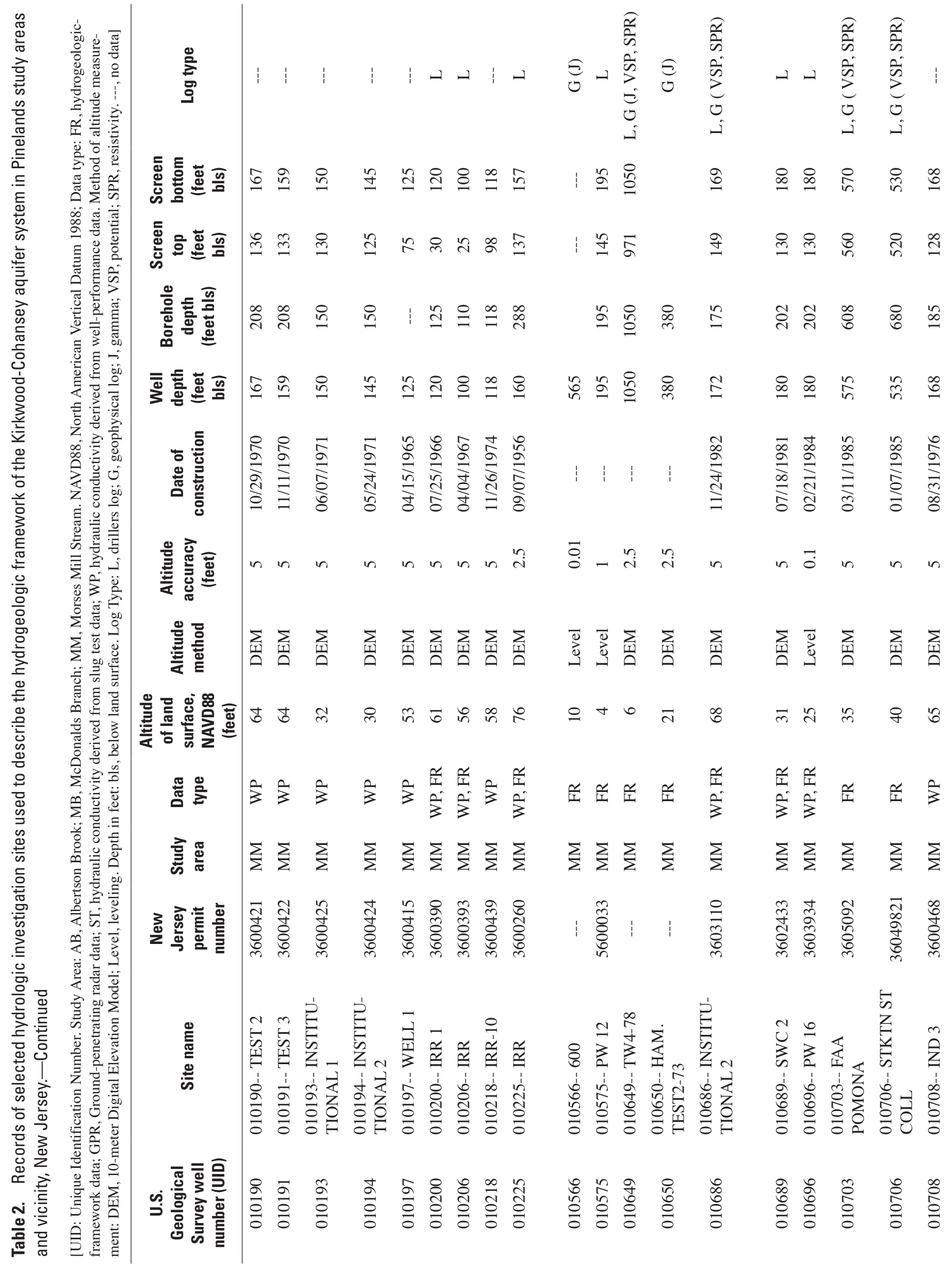



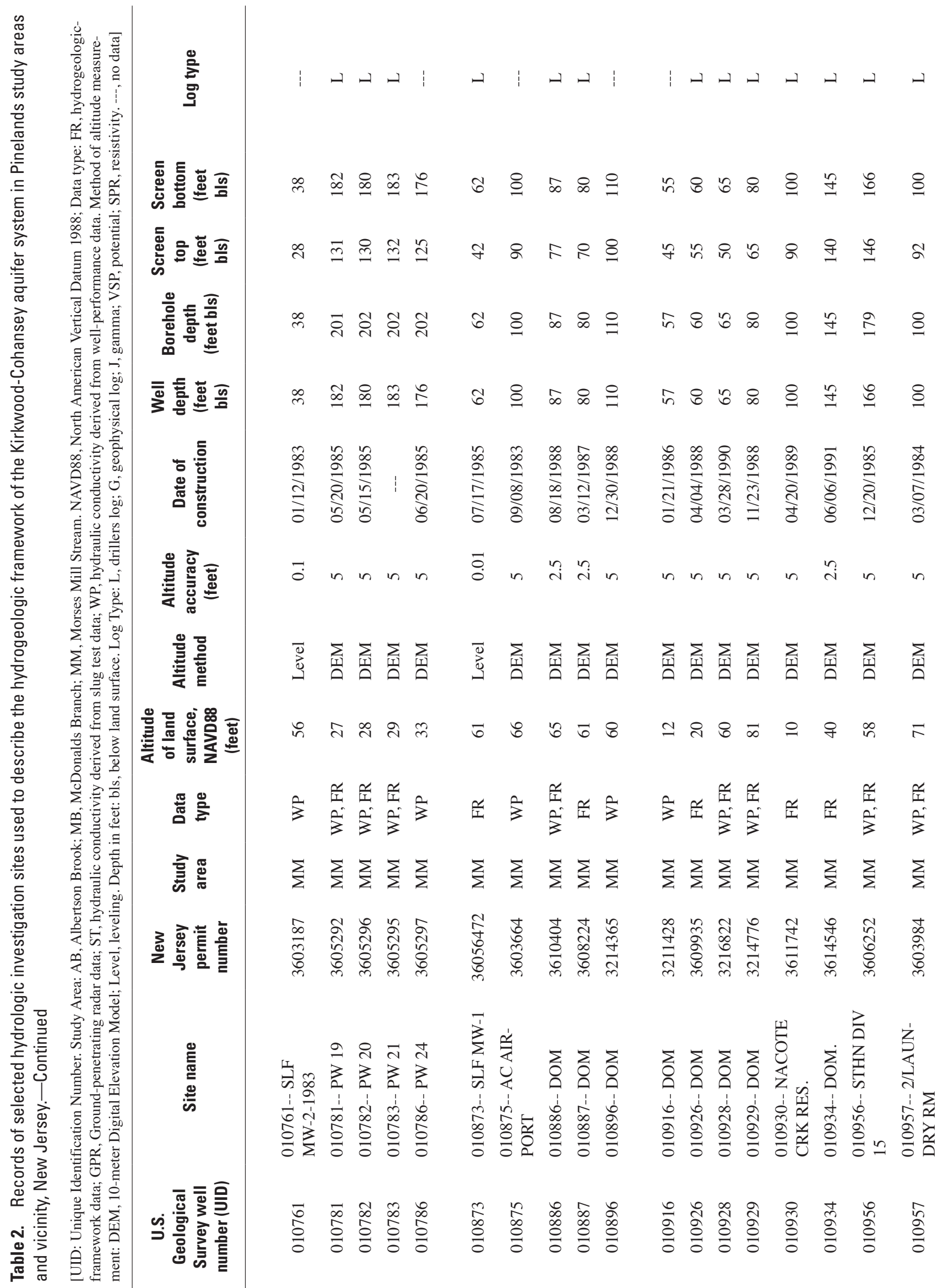


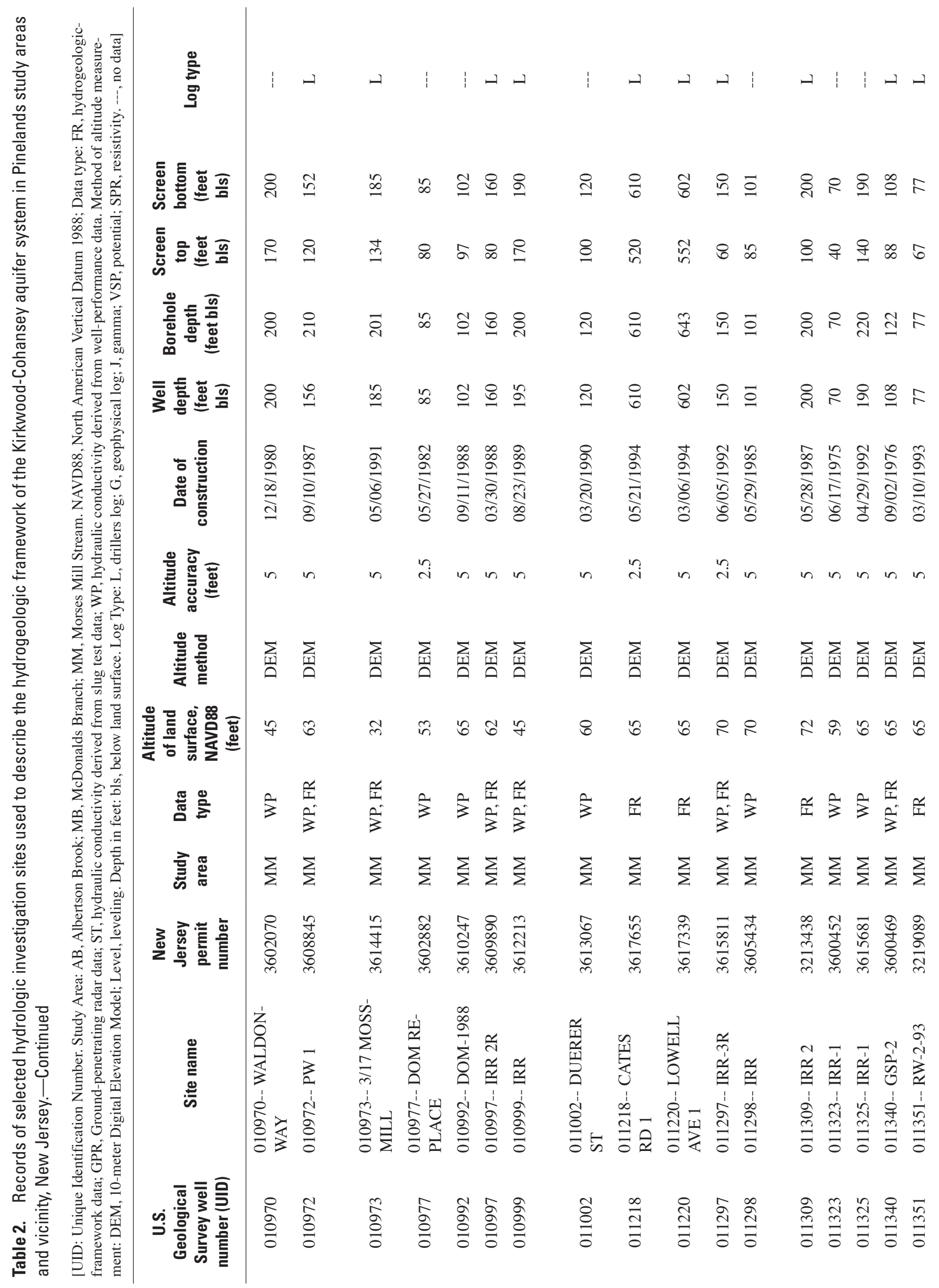




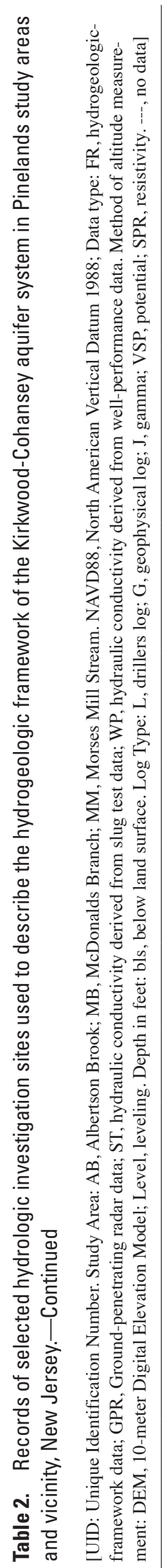

\begin{tabular}{|c|c|c|c|}
\hline$\underline{\underline{z}}$ & 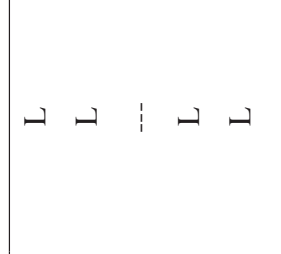 & 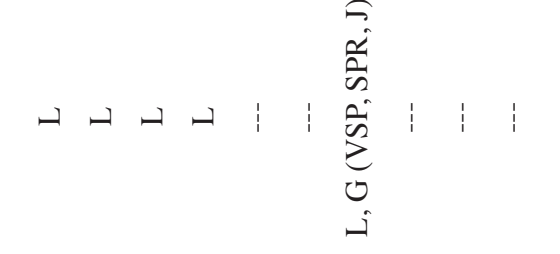 & 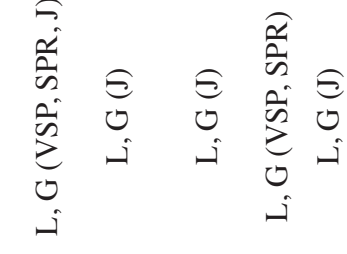 \\
\hline 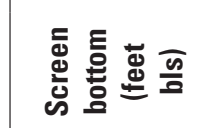 & 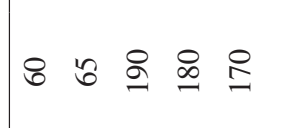 & 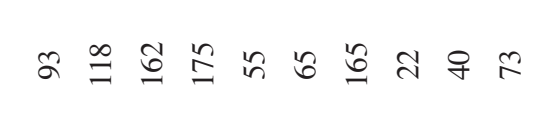 & 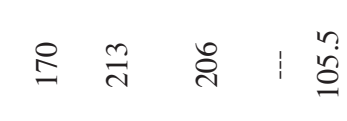 \\
\hline 20 & 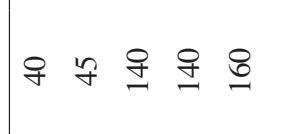 & 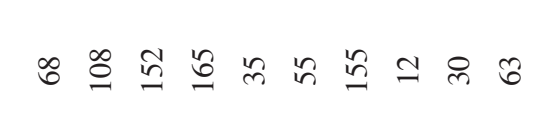 & $\stackrel{g}{g} \cong$ \\
\hline & 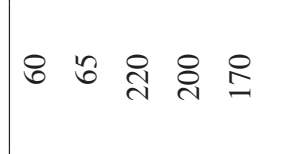 & 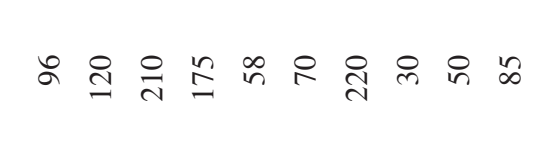 & 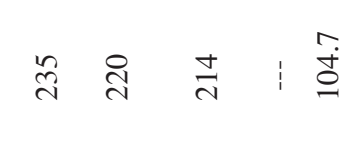 \\
\hline & 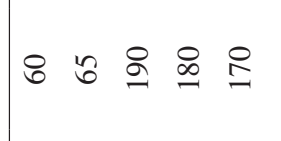 & 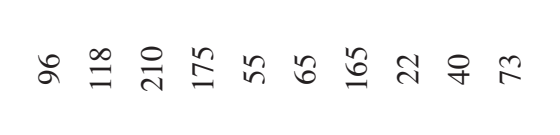 & 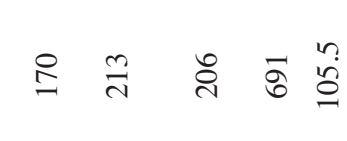 \\
\hline & 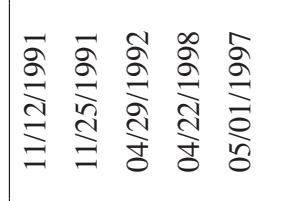 & 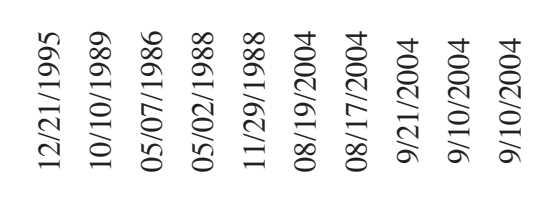 & 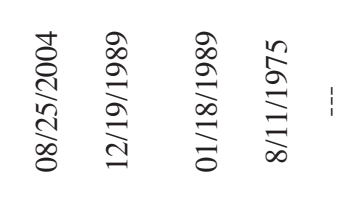 \\
\hline 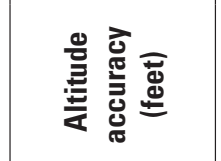 & $\ln \sin 2 x$ & ganononononon & $n n \sin \overline{0}$ \\
\hline & 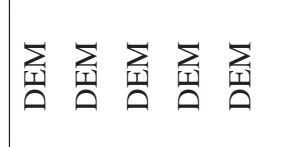 & 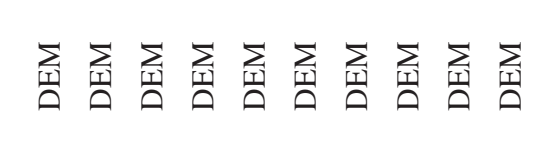 & 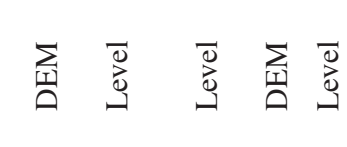 \\
\hline 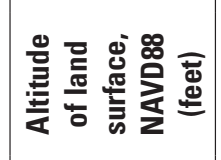 & $88: 50$ & 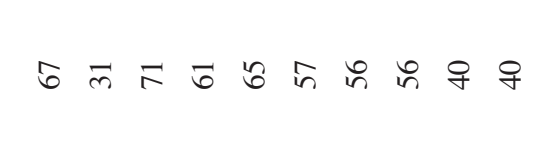 & o i $\infty$ \\
\hline$\frac{\mathrm{a}}{\mathrm{a}} \frac{\mathrm{a}}{\mathrm{a}}$ & 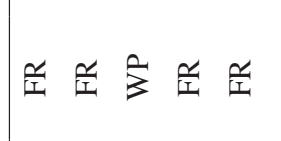 & 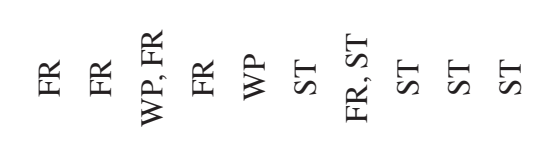 & 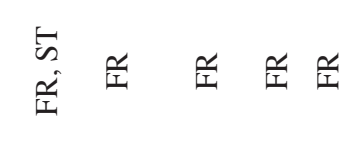 \\
\hline 害哭 & 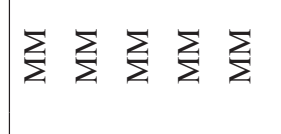 & 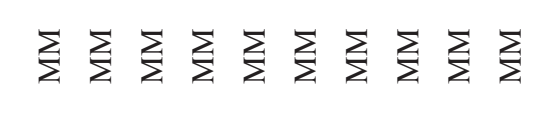 & $\sum_{\overline{2}}^{\bar{n}} \sum_{2}^{\bar{n}} \sum_{2}$ \\
\hline 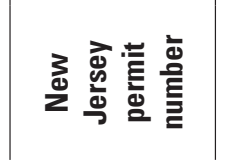 & 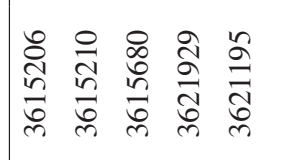 & 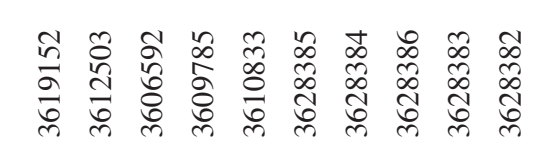 & 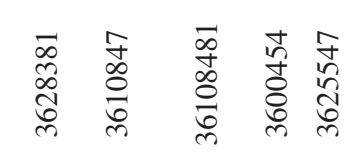 \\
\hline & 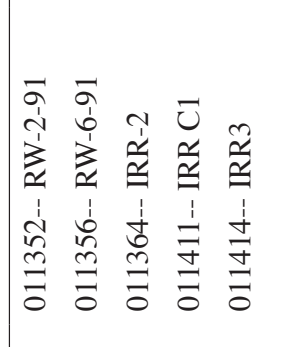 & 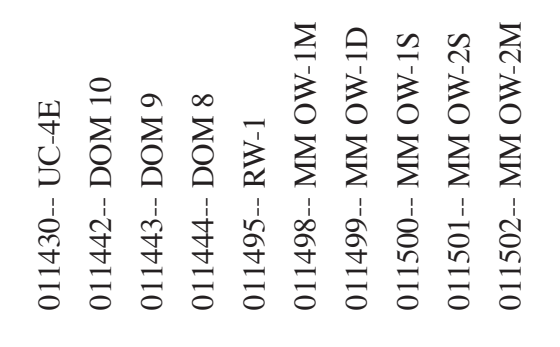 & 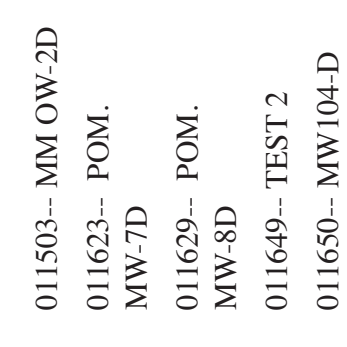 \\
\hline 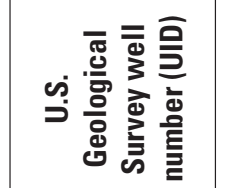 & 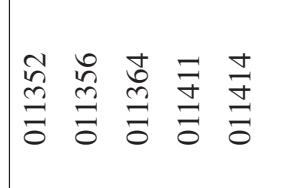 & 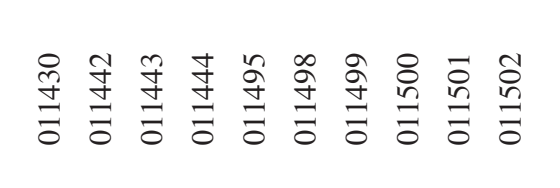 & 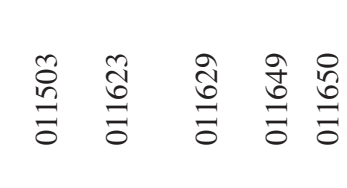 \\
\hline
\end{tabular}




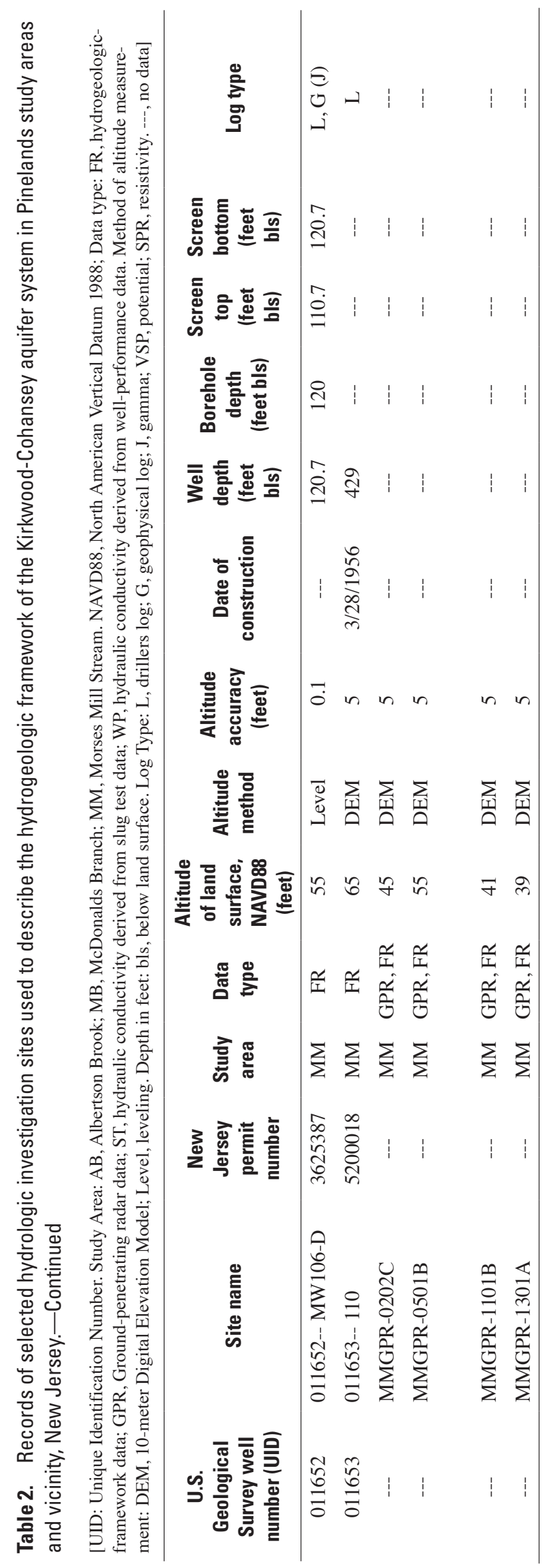




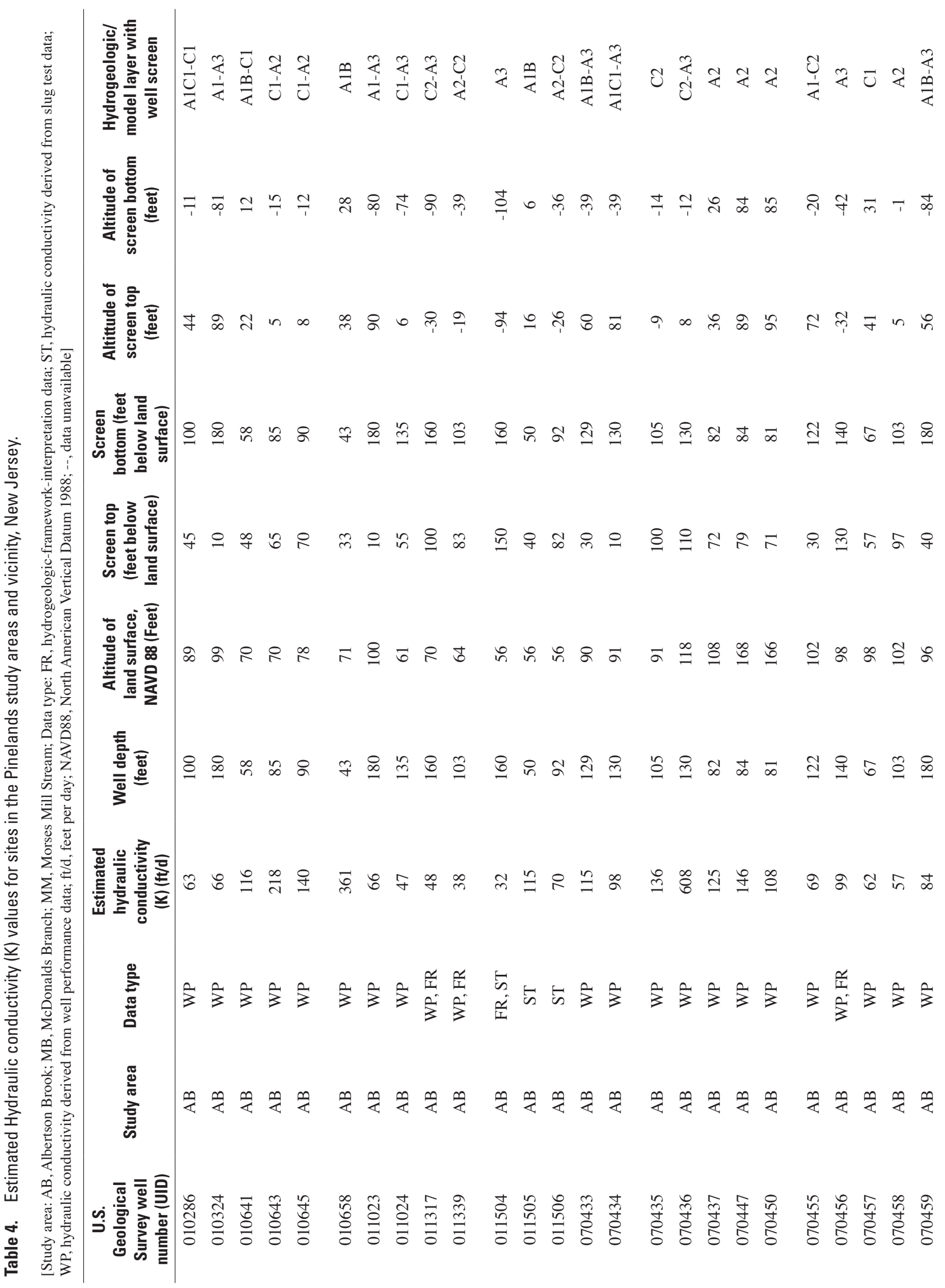




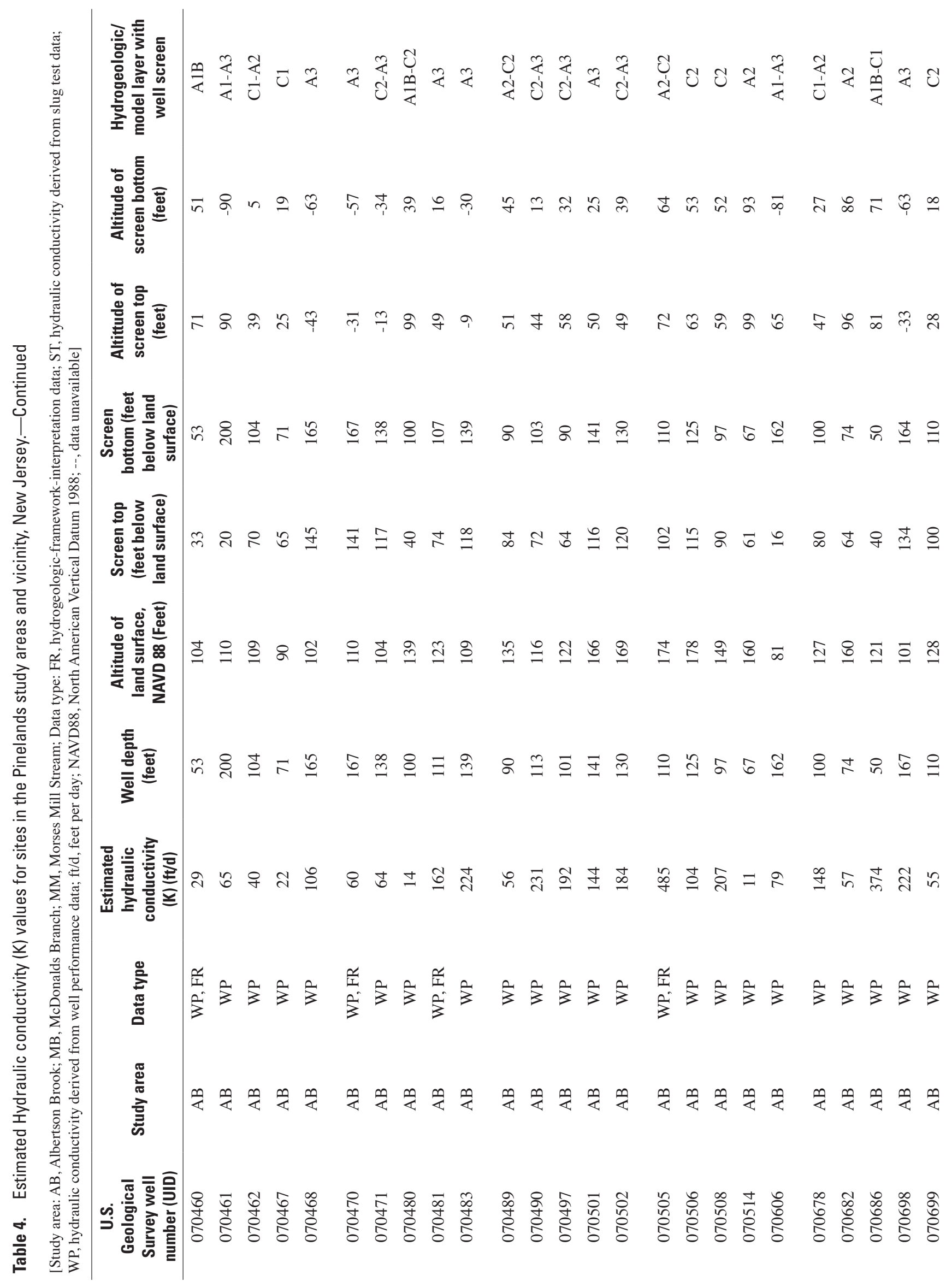




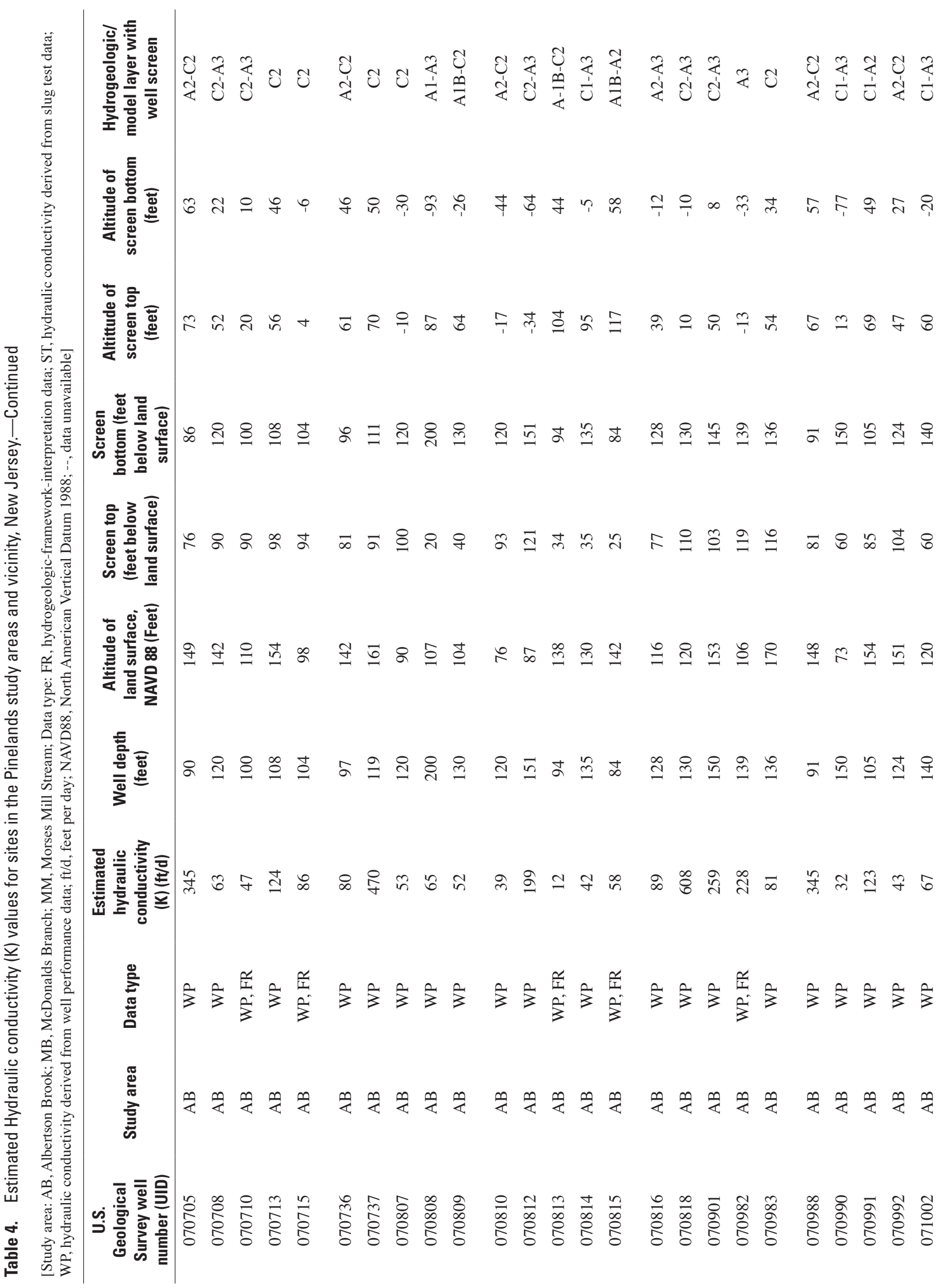




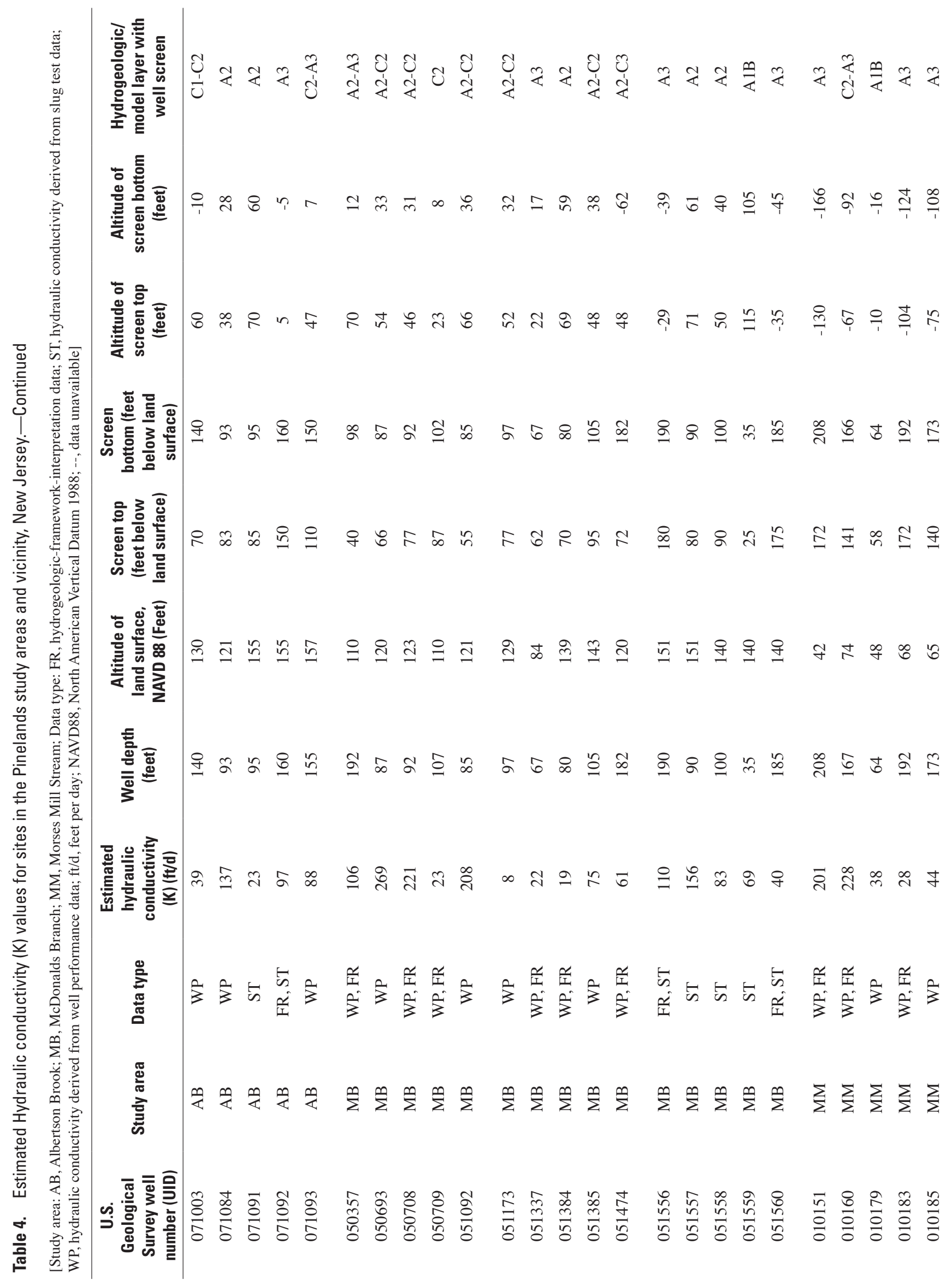




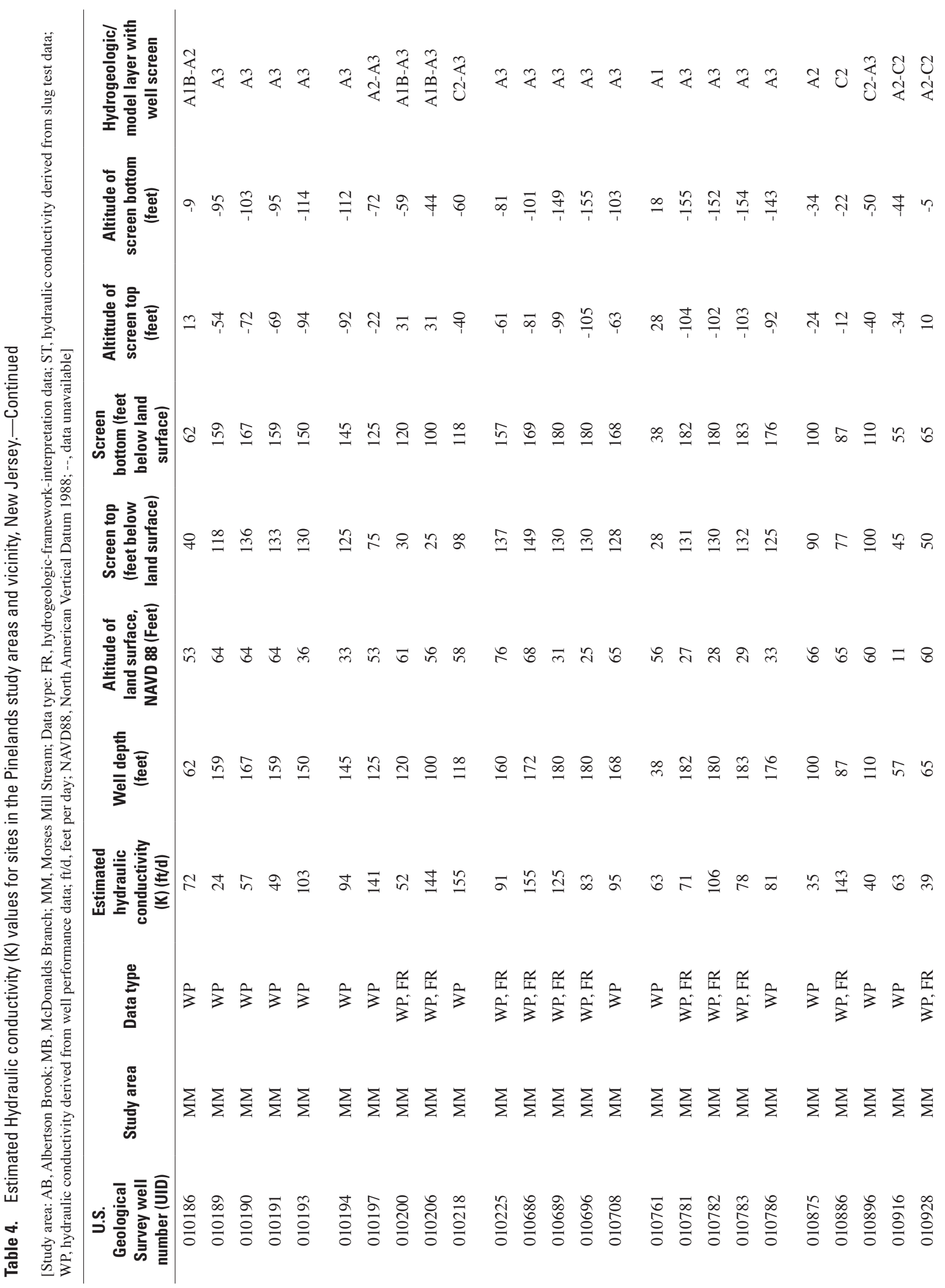




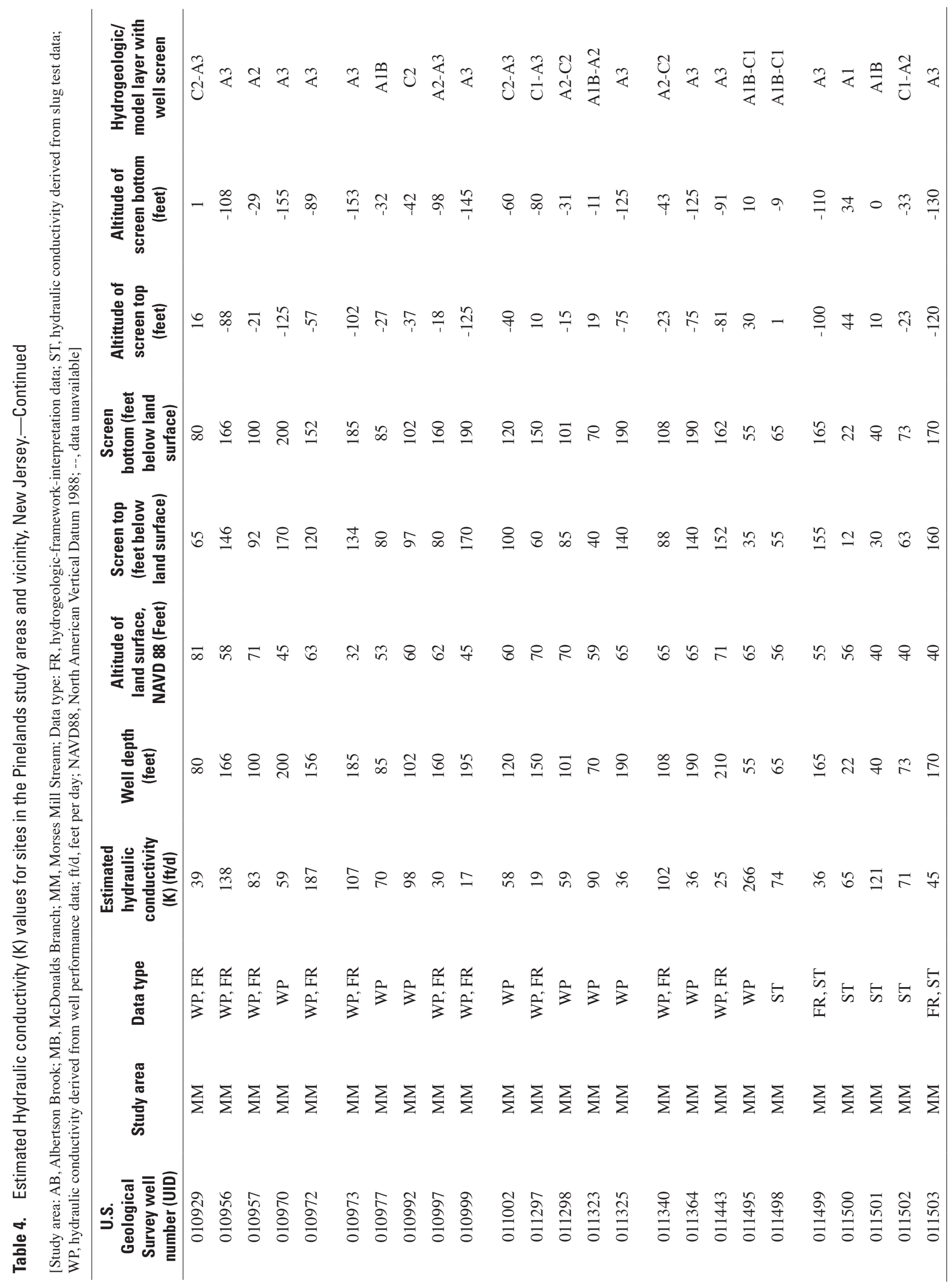





\section{Appendix 1}

Lithologic and geophysical logs of selected boreholes and newly installed wells in Kirkwood-Cohansey aquifer system, New Jersey Pinelands. 
GAMMA LOG

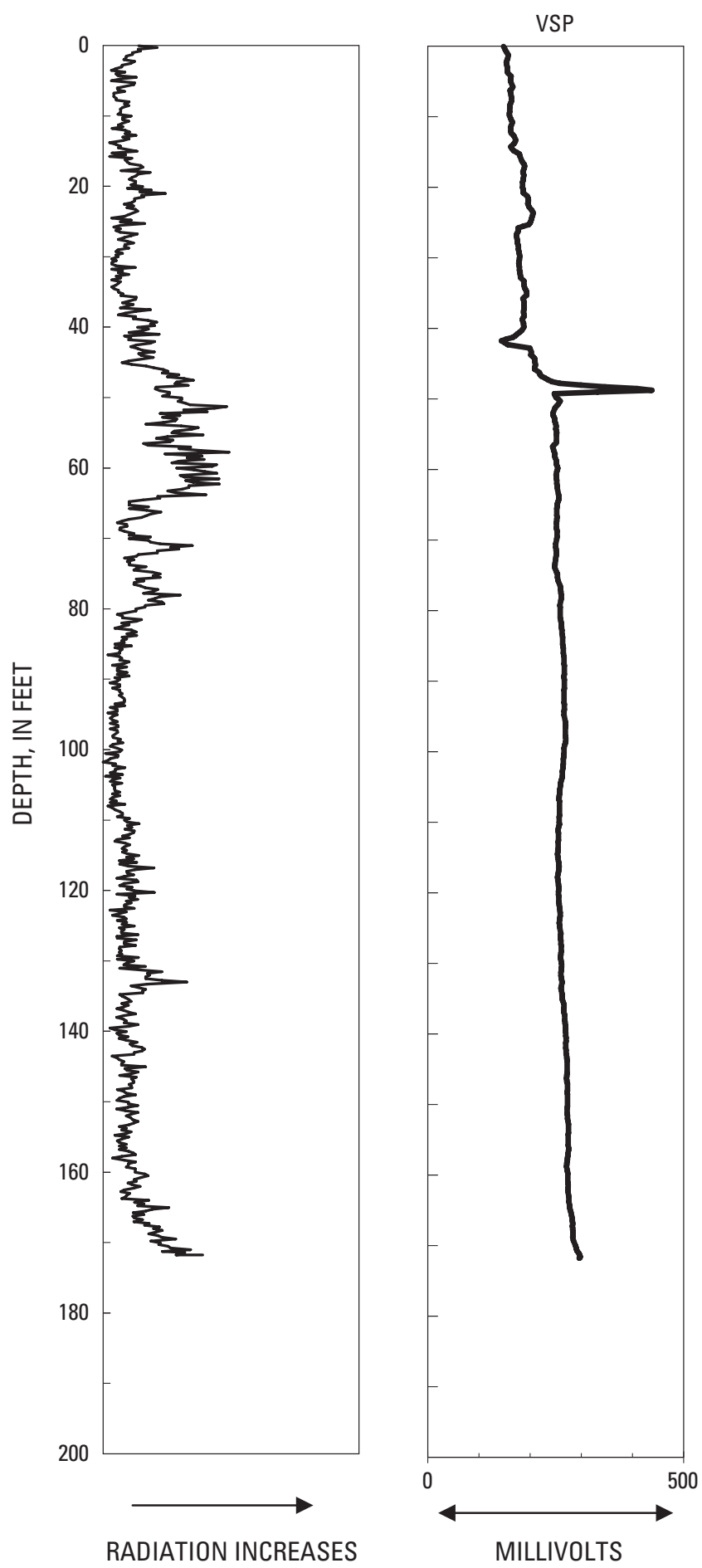

ELECTRIC LOGS

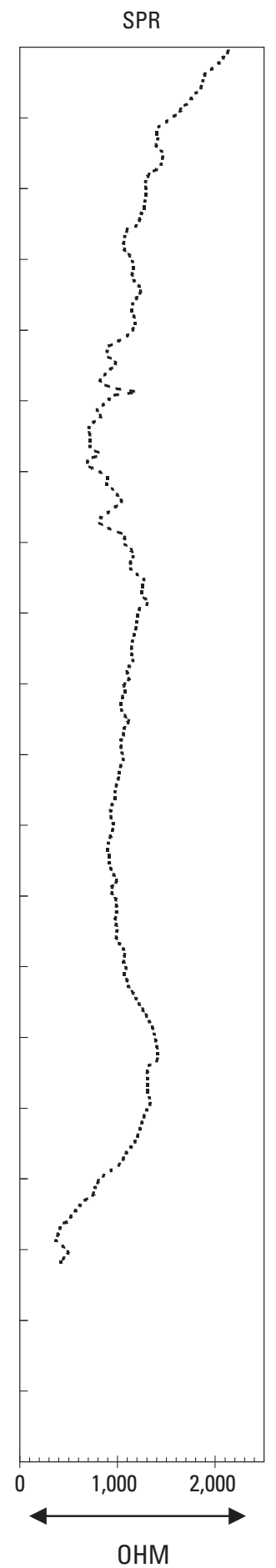

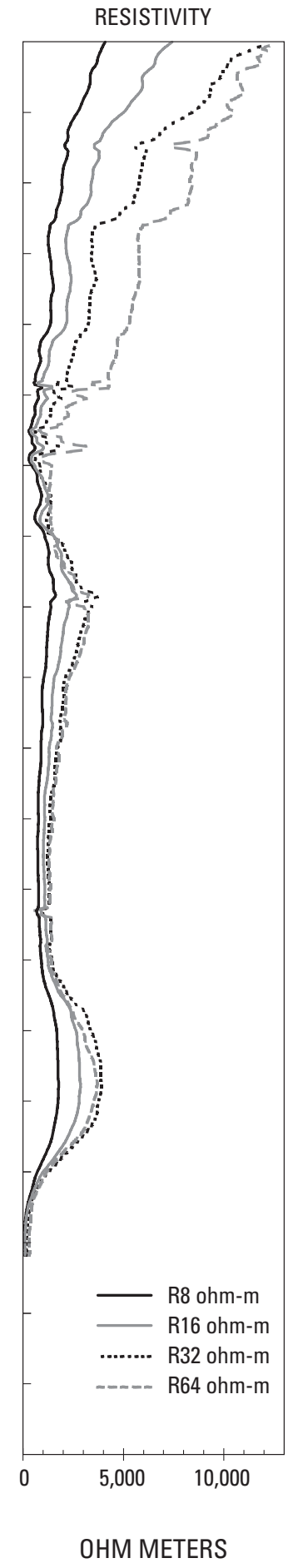

Figure 1-1. Geophysical logs of AB OW-1D (Well number 071092). 
AB OW-1D Boring Log (Well Number 071092, location shown on figure 6.)

\begin{tabular}{|c|c|c|}
\hline $\begin{array}{c}\text { Top of } \\
\text { interval } \\
\text { (ft })^{1}\end{array}$ & $\begin{array}{c}\text { Bottom of } \\
\text { interval } \\
\text { (ft) }\end{array}$ & Description of cuttings unless noted otherwise \\
\hline 20 & 25 & Sand and gravel, medium to very coarse, contains thin clay layers, $\tan$ \\
\hline 25 & 30 & $\begin{array}{l}\text { Sand and gravel, medium to very coarse, trace iron cemented sand, with some layers of clay, medium } \\
\text { dense, silty, yellow, } 10 \mathrm{yr} 7 / 6\end{array}$ \\
\hline 30 & 40 & Fine sand indicated by drilling - cuttings contain fine sand and soft clay \\
\hline 40 & 45 & $\begin{array}{l}\text { Sand indicated by drilling - cuttings contain sand medium to very coarse gravel fine and some clay, very } \\
\text { soft, tan }\end{array}$ \\
\hline 45 & 50 & Sand, very coarse, gravel fine, some iron cemented sand, cuttings contain $30 \%$ to $40 \%$ clay, silty, soft, $\tan$ \\
\hline 50 & 60 & $\begin{array}{l}\text { Clay indicated by drilling from } 53 \mathrm{ft} \text { to } 55 \mathrm{ft} \text { - cuttings contain clay, light gray some heavily oxidized to } \\
\text { yellow, 10YR 7/6 and fine gravel, } 20 \%\end{array}$ \\
\hline 70 & 76 & Clay, sandy, silty, tan/yellow oxidized to orange and clay, very dark gray 10YR 3/1 \\
\hline 76 & 85 & Sand indicated by drilling - cuttings contain fine to very coarse sand and about $50 \%$ clay \\
\hline 85 & 90 & Sand, fine to very coarse, trace iron cemented sand \\
\hline 90 & 95 & Sand, fine to very coarse, trace iron cemented sand, and $30 \%$ clay, sandy in cuttings \\
\hline 95 & 100 & Sand, medium to very coarse and gravel, fine, and $10 \%$ clay, sandy in cuttings \\
\hline 100 & 105 & Sand, medium to very coarse and gravel, fine $20 \%$ \\
\hline 135 & 140 & Gravel, very coarse. Clay layer indicated by drilling at 137 feet \\
\hline 140 & 145 & $\begin{array}{l}\text { Gravel, fine to medium, cuttings contain about } 20 \% \text { clay, soft, sandy, mixed with gravel. Drilling indi- } \\
\text { cates sand and gravel. Lenses of sand and gravel are likely }\end{array}$ \\
\hline 145 & 150 & Gravel, fine to medium, trace clay, trace cemented sand \\
\hline 150 & 160 & Gravel, fine to medium, trace clay, trace cemented sand \\
\hline 160 & 169 & Sand, very fine to coarse, trace clay \\
\hline 169 & 176 & Clay, very dark gray, soft, organic \\
\hline 176 & 180 & Clay, medium dense, very dark gray $10 \mathrm{YR} 3 / 1,10 \%$ mica \\
\hline 180 & 181.8 & Clay, very dark gray 10 YR 3/1, <10\% mica, silty, dense--Split spoon sample, $100 \%$ recovery \\
\hline
\end{tabular}

\footnotetext{
${ }^{1}$ The soil matrix and color descriptions for all newly drilled boreholes were determined by comparing appropriate samples using the Munsell Soil Color Charts (1975 ed.), available from Macbeth Division, Kollmorgen Instruments Corporation, 405 Little Britain Rd. New Windsor, N.Y. 12553
} 
GAMMA LOG

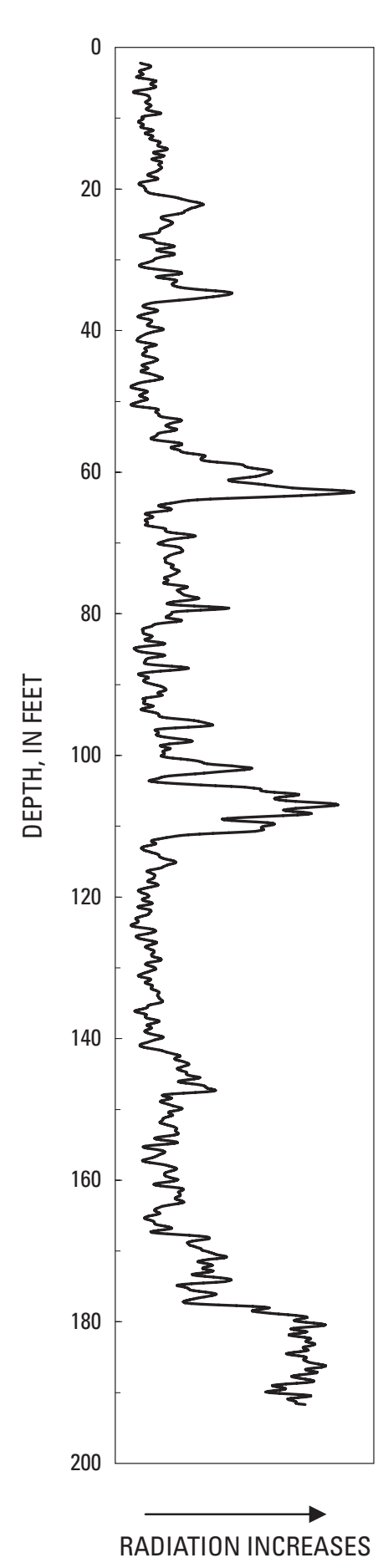

ELECTRIC LOGS

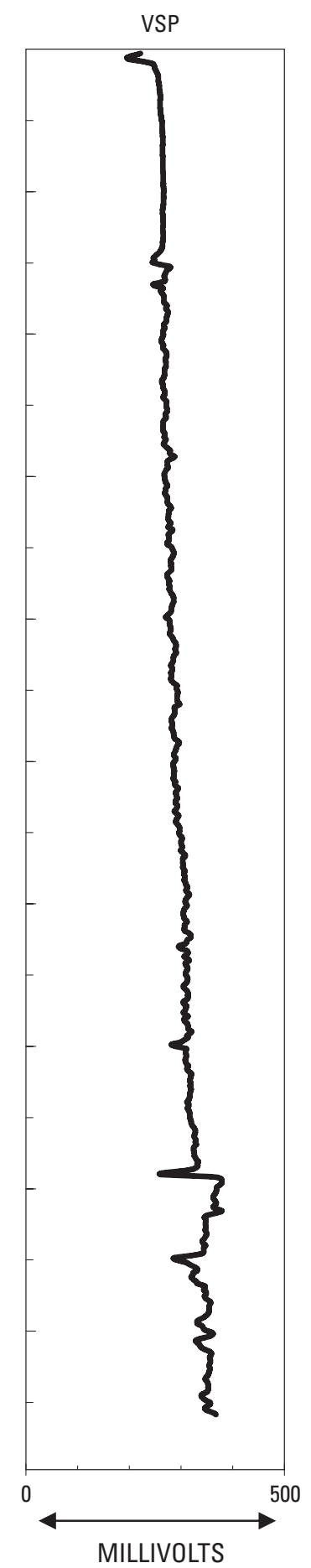

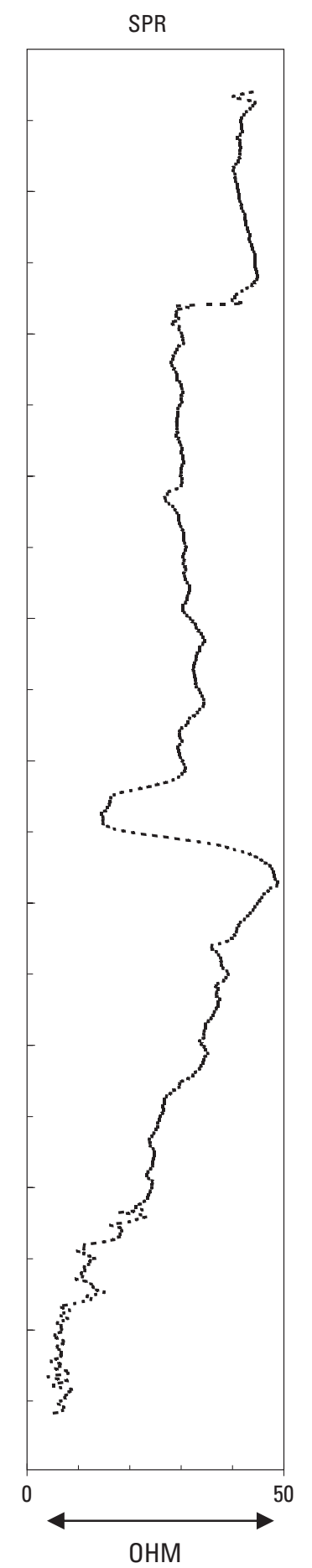

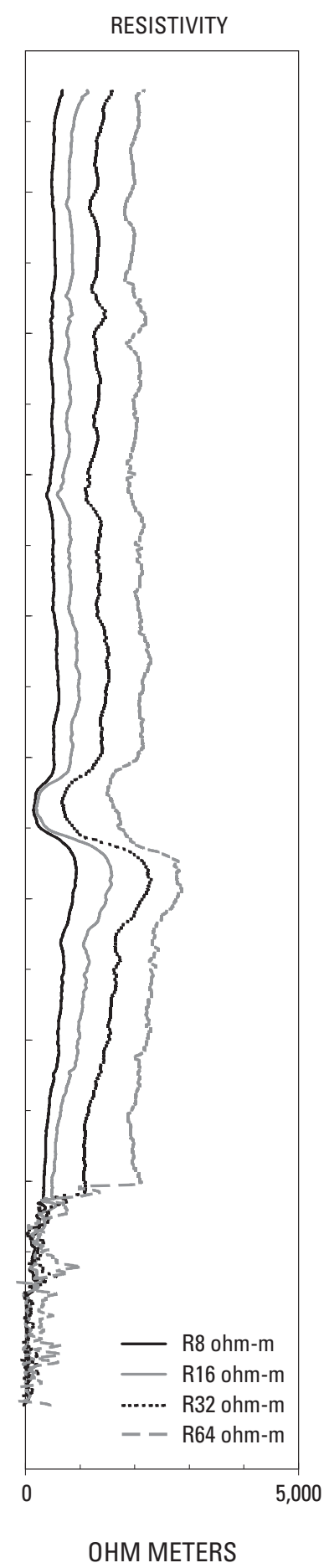

Figure 1-2. Geophysical logs of $A B D W-2 D$ (Well number 011504) 


\section{AB OW-2D Boring Log (Well Number 011504 location shown on figure 6.)}

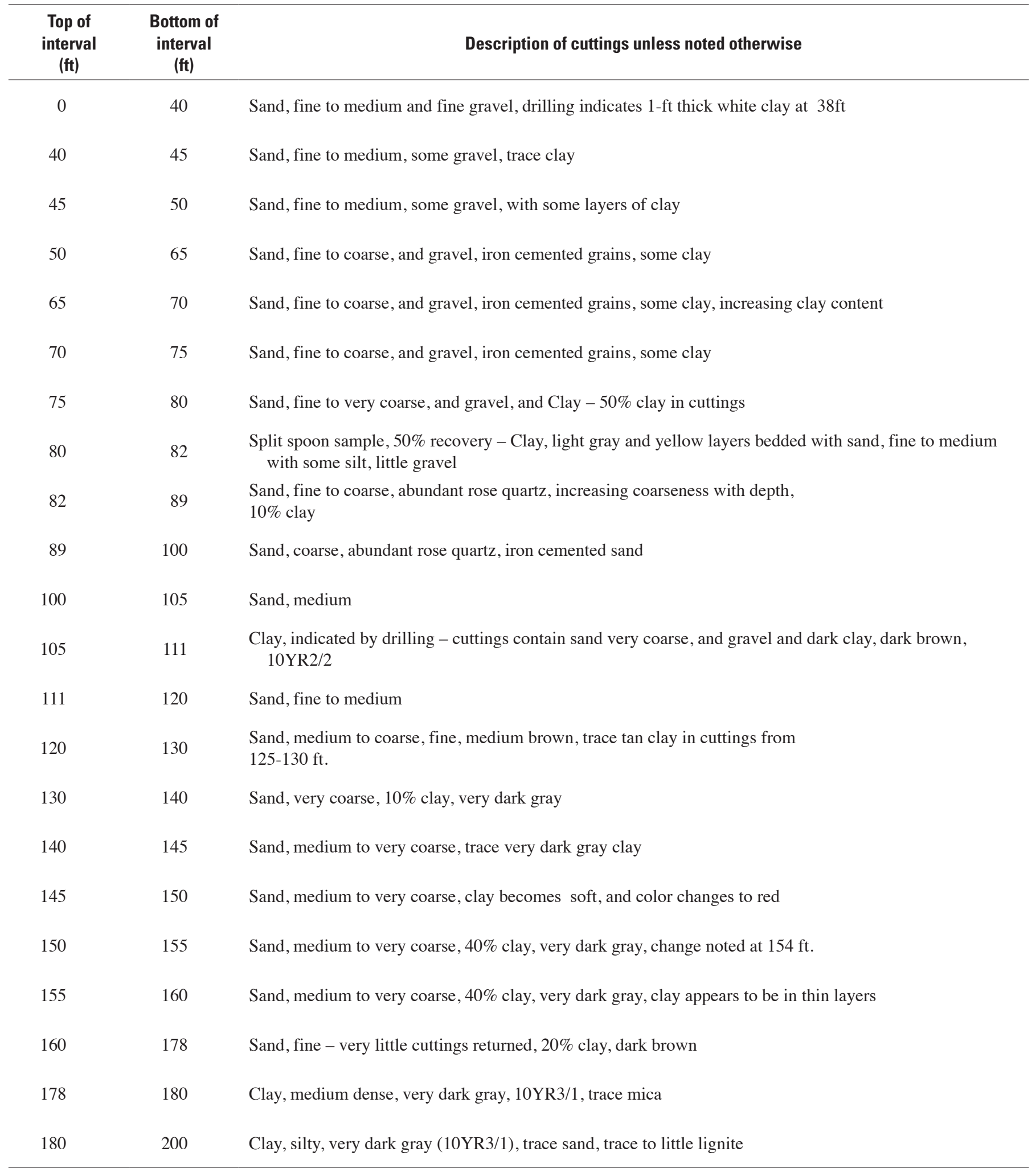




\section{Shallow boreholes completed in the Albertson Brook basin using Geoprobe ${ }^{\circledR}$ sediment sampling equipment and used in the interpretation of GPR records.}

ALB-B1 (Well Number 011497, location shown on figure 12.)

\begin{tabular}{|c|c|c|}
\hline $\begin{array}{l}\text { Top of } \\
\text { interval } \\
\text { (ft) }\end{array}$ & $\begin{array}{c}\text { Bottom of } \\
\text { interval } \\
\text { (ft) }\end{array}$ & Description of sediments from core samples \\
\hline 0 & 4 & Sand, fine to medium grained, poorly sorted - saturated at 3 feet \\
\hline 4 & 6.2 & Sand, fine to medium with some coarse sand and gravel \\
\hline 6.2 & 8 & Sand, fine to medium grained \\
\hline 8 & 12 & Sand, fine to coarse grained \\
\hline
\end{tabular}

ALB-B2 (Well Number 011496, location shown on figure 12.)

\begin{tabular}{|c|c|c|}
\hline $\begin{array}{l}\text { Top of } \\
\text { interval } \\
\text { (ft) }\end{array}$ & $\begin{array}{c}\text { Bottom of } \\
\text { interval } \\
\text { (ft) }\end{array}$ & Description of sediments from core samples \\
\hline 0 & 1.2 & Sand, fine to very fine grained \\
\hline 1.2 & 2.3 & Sand, fine to coarse grained, becoming fine to very fine at 2.3 feet \\
\hline 2.3 & 4.0 & No recovery \\
\hline 4.0 & 6.4 & Sand, fine grained, saturated at 6 feet \\
\hline 6.4 & 8.0 & Alternating layers of clay and sand, very fine to fine grained \\
\hline 8.0 & 11.4 & Sand, fine, well sorted, clay present in thin layers, some oxidized zones \\
\hline
\end{tabular}

ALB-B3 (Well Number 071088, location shown in figure 12.)

\begin{tabular}{|c|c|c|}
\hline $\begin{array}{l}\text { Top of } \\
\text { interval } \\
\text { (ft) }\end{array}$ & $\begin{array}{l}\text { Bottom of } \\
\text { interval } \\
\text { (ft) }\end{array}$ & Description of sediments from core samples \\
\hline 0 & 6.7 & Sand, fine grained, poorly sorted \\
\hline 6.7 & 7 & Clayey sand \\
\hline 7 & 16 & Sand, fine to coarse grained, little clay layers, occasional gravel, saturated at 9 feet \\
\hline 16 & 20 & Sand, fine to very fine grained, with thin clay layers in the interval from 16 to 17.6 feet \\
\hline
\end{tabular}

ALB-B4 (Well Number 071089, location shown on figure 12.)

\begin{tabular}{ccl}
\hline $\begin{array}{c}\text { Top of } \\
\text { interval } \\
(\mathbf{f t})\end{array}$ & $\begin{array}{c}\text { Bottom of } \\
\text { interval } \\
(\mathbf{f t})\end{array}$ & \\
\hline 0 & 4 & Sand, fine to medium grained little gravel \\
4 & 8 & Sand, fine grained to gravel, small amount of clay \\
8 & 13.5 & Sand, fine grained to gravel, saturated at 12 feet \\
13.5 & 14.2 & Clay with fine grained sand \\
14.2 & 16 & Sand, fine grained to gravel \\
16 & 20 & Sand, fine to medium, with coarse sand and gravel \\
20 & 23.5 & Sand, fine to very fine grained \\
23.5 & 24 & Sand, fine to coarse grained \\
24 & 28 & Sand, fine to very fine grained \\
\hline
\end{tabular}




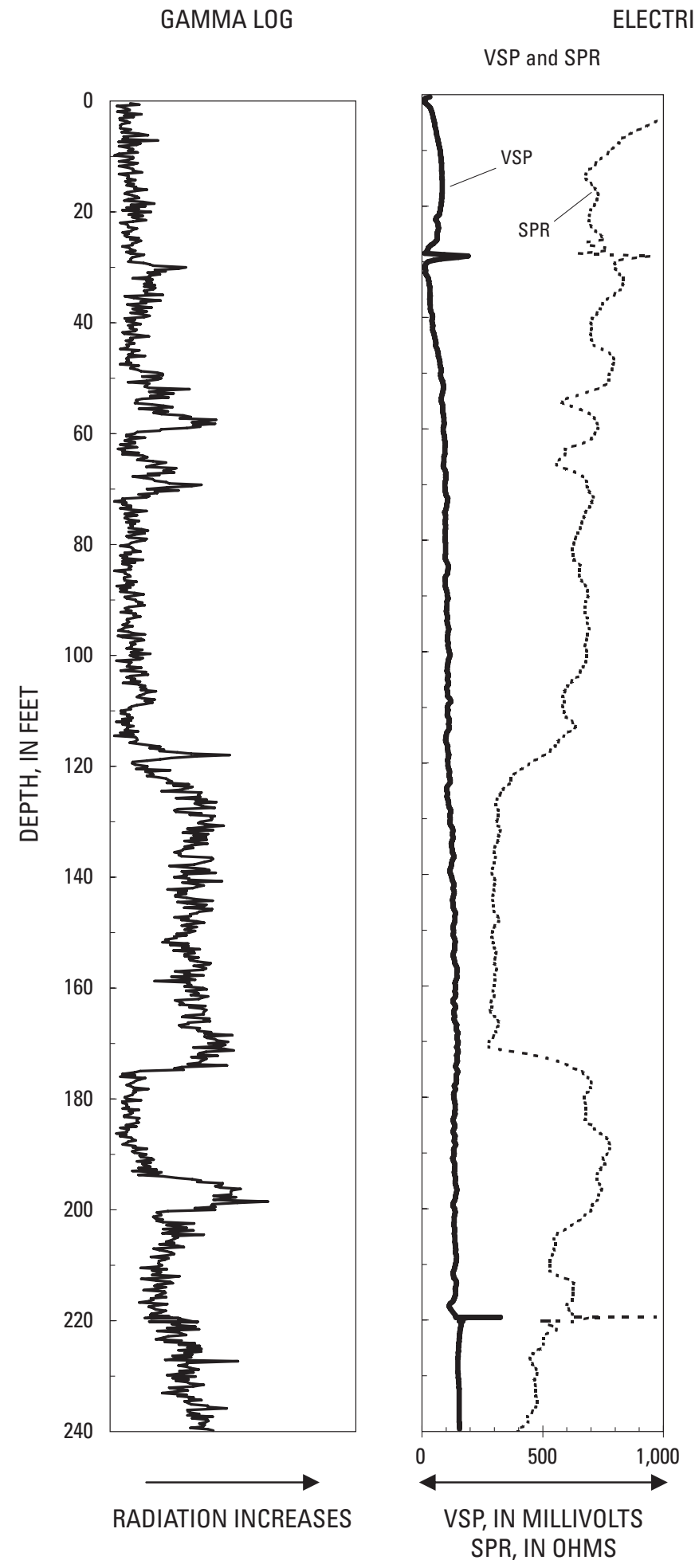

RESISTIVITY

CALIPER LOG
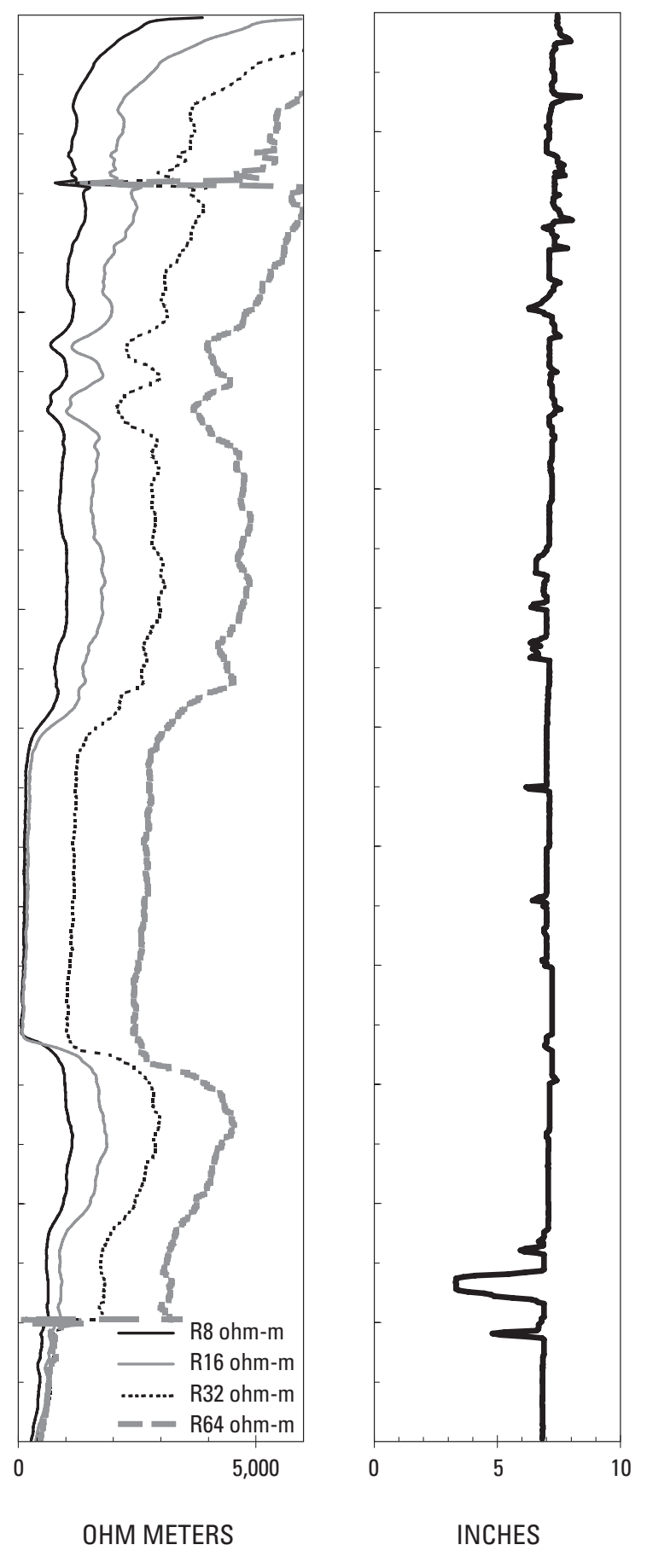

Figure 1-3. Geophysical logs of MB OW-1D (Well number 051556). 
MB OW-1D Boring Log (Well Number 051556, location shown on figure 13.)

\begin{tabular}{|c|c|c|}
\hline $\begin{array}{l}\text { Top of } \\
\text { interval } \\
\text { (ft) }\end{array}$ & $\begin{array}{c}\text { Bottom of } \\
\text { interval } \\
\text { (ft) }\end{array}$ & Description of cuttings unless noted otherwise \\
\hline 1 & 5 & Sand, fine to very coarse, trace gravel \\
\hline 5 & 15 & Sand, fine to very coarse, $20 \%$ gravel \\
\hline 23 & 25 & Sand, fine to very coarse, $20 \%$ gravel, trace yellow sandy clay in cuttings \\
\hline 25 & 34 & Sand, fine to very coarse, $20 \%$ gravel \\
\hline 34 & 40 & $\begin{array}{l}\text { Clay indicated by drilling, cuttings: Clay, medium dense, mottled red and gray and very coarse grave, trace } \\
\text { iron cemented sand }\end{array}$ \\
\hline 53 & 54 & Clay indicated by drilling \\
\hline 54 & 61 & Clay and sand and gravel layers - cuttings contain clay red, white, and yellow and $30 \%$ gravel \\
\hline 61 & 80 & $\begin{array}{l}\text { Sand and clay layers indicated by drilling - cuttings contain clay, silty and sandy, mottled, yellow, light gray } \\
\text { and tan and } 30 \% \text { sand medium to very coarse with iron cemented sand }\end{array}$ \\
\hline 80 & 83 & Sand, medium to very coarse and fine gravel \\
\hline 83 & 85 & $\begin{array}{l}\text { Sand and Clay, light to medium gray layers, fine to very coarse, trace iron cemented sand, and } 30 \% \text { clay, } \\
\text { sandy in cuttings }\end{array}$ \\
\hline 85 & 93 & Sand, coarse to very coarse, layered with $20 \%$ clay, light gray \\
\hline 93 & 100 & Sand and gravel indicated by drilling- cuttings contain sand medium to very coarse and gravel fine to coarse \\
\hline 120 & 126 & Sand indicated by drilling, cuttings contain $60 \%$ clay \\
\hline 126 & 140 & Clay, medium dense, silty, very dark gray $10 \mathrm{YR} 2 / 2$ \\
\hline 140 & 145 & Clay, medium dense, silty, very dark brown, trace mica \\
\hline 145 & 160 & Clay, medium dense, silty, very dark brown, trace mica, increasing mica content, trace, yellow clay \\
\hline 160 & 178 & Sand indicated by drilling - cuttings contain only clay \\
\hline 178 & 200 & Sand, medium to very coarse - principally clay in cuttings \\
\hline 200 & 220 & Finer sediments indicated by drilling - cuttings contain $10 \%$ gravel, $10 \%$ yellow sand, fine and $80 \%$ clay \\
\hline 220 & 228 & Sand or silt indicated by drilling - no cutting returned \\
\hline 228 & 240 & Clay and fine silt or sand layers indicated by drilling \\
\hline 240 & 250 & Clay, brown and dark gray, occasional sand layers indicated by drilling \\
\hline
\end{tabular}



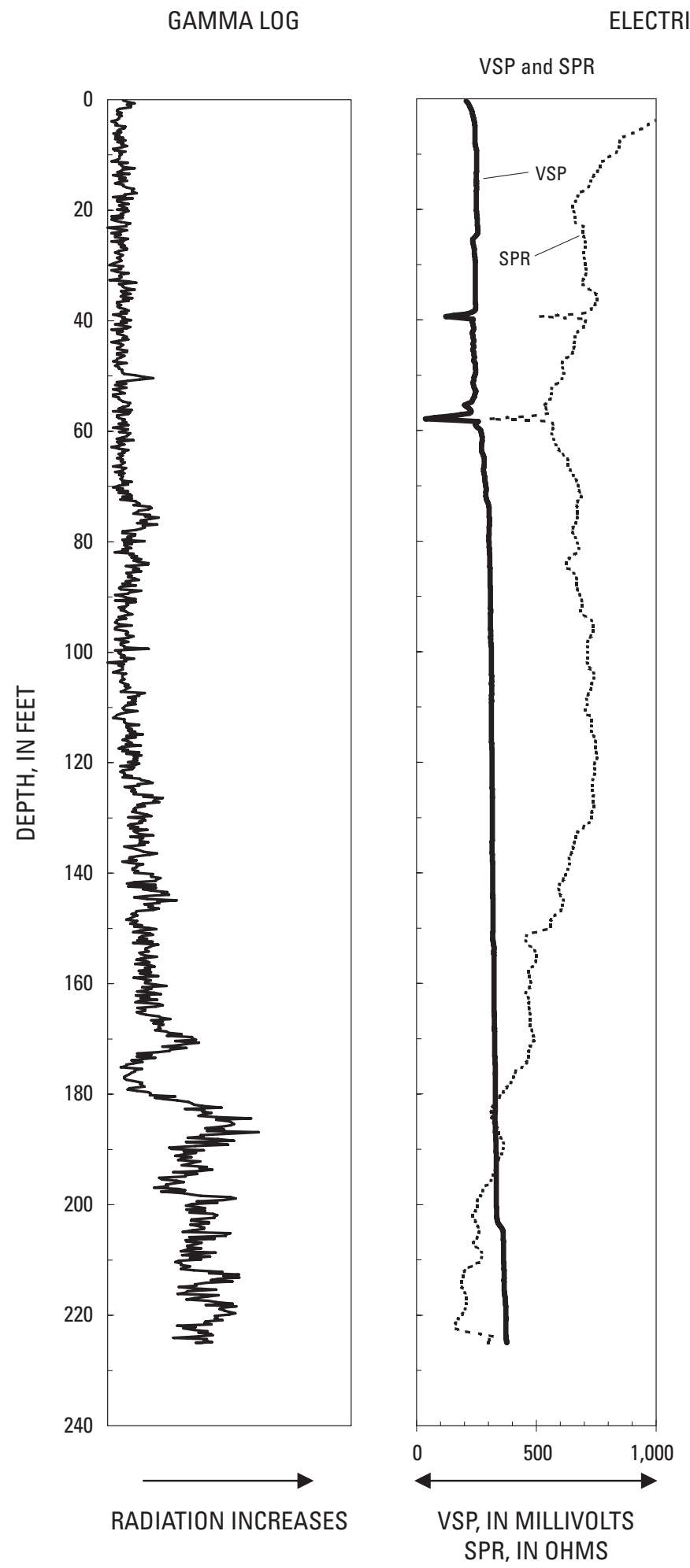

RESISTIVITY

CALIPER LOG
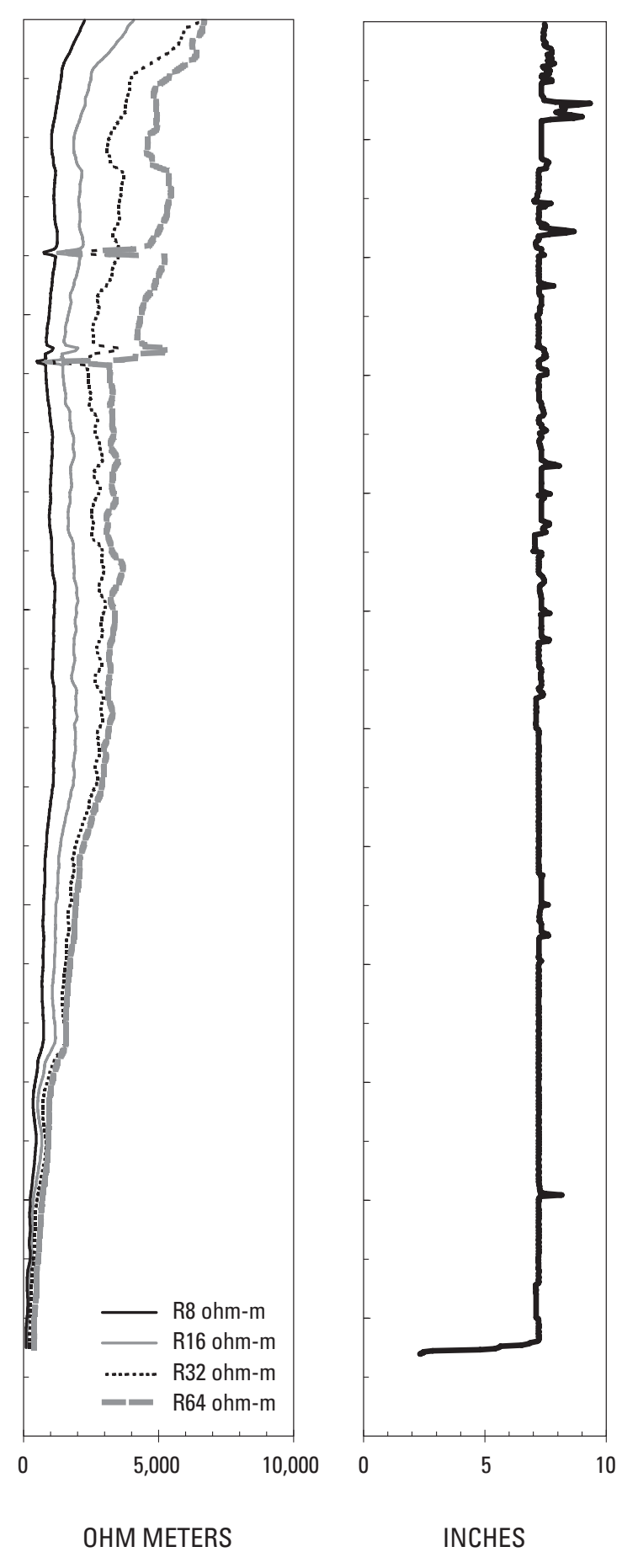

Figure 1-4. Geophysical logs of MB OW-2D (Well number 051560). 
MB OW-2D Boring Log (Well Number 051560; location shown on figure 13.)

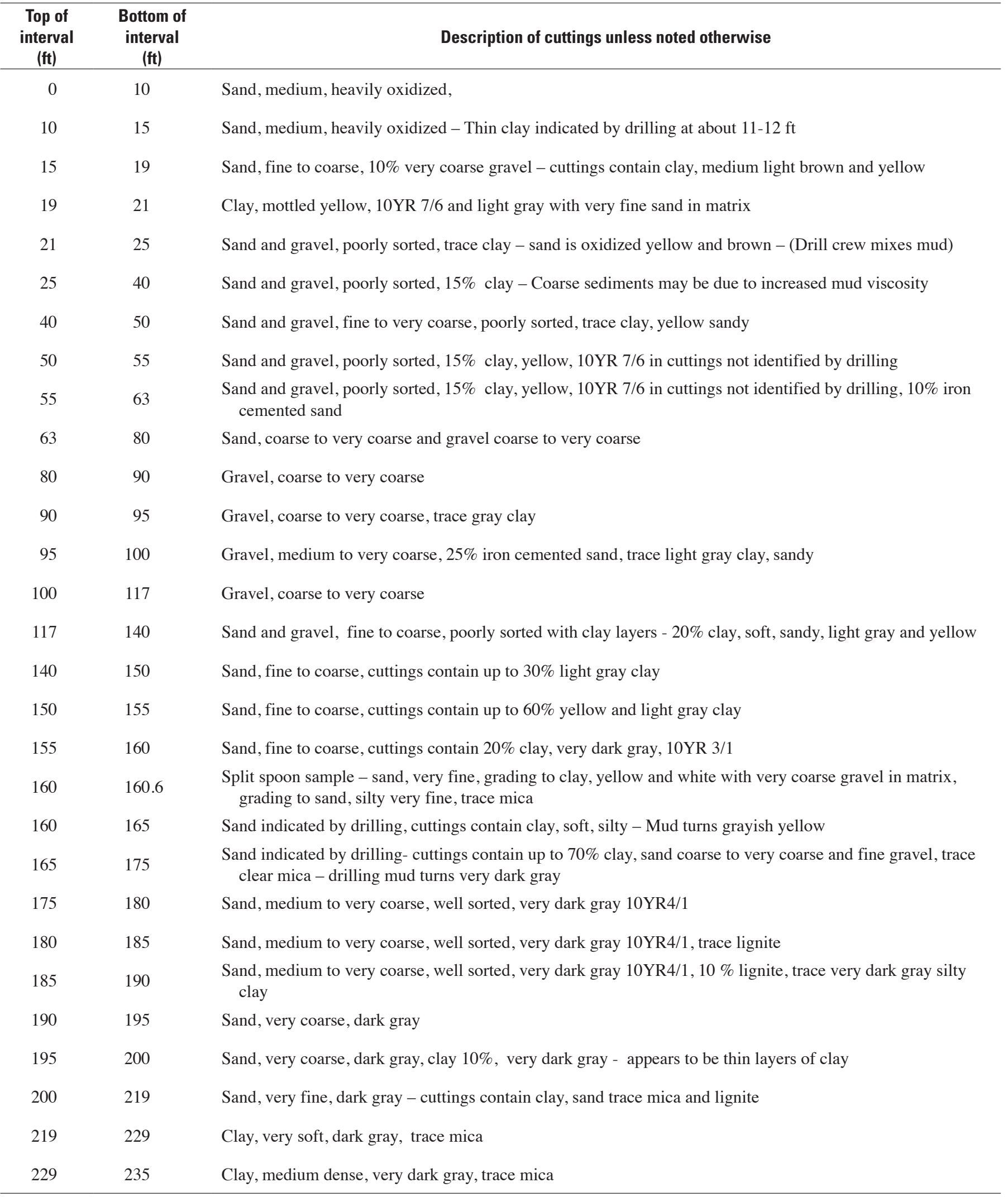


GAMMA LOG

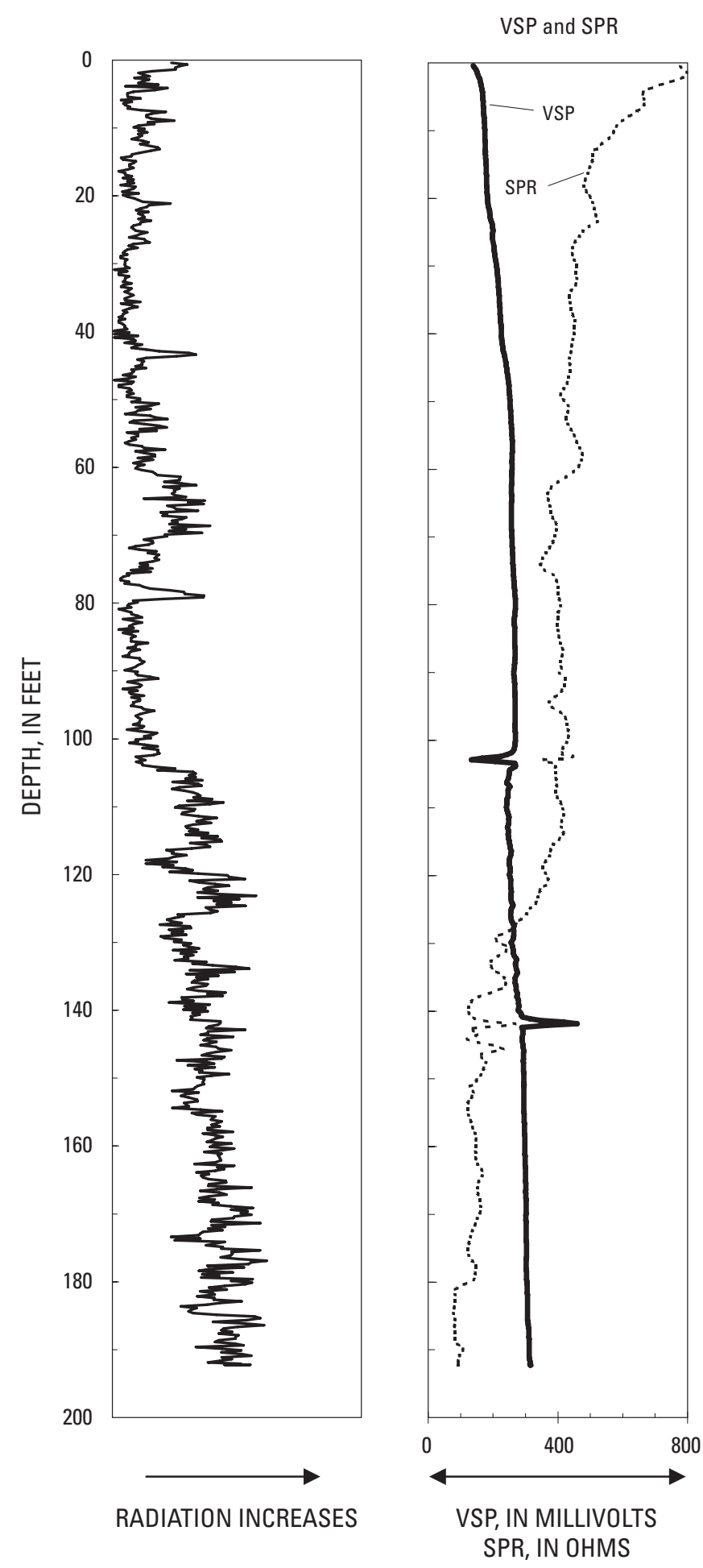

CALIPER LOG

RESISTIVITY
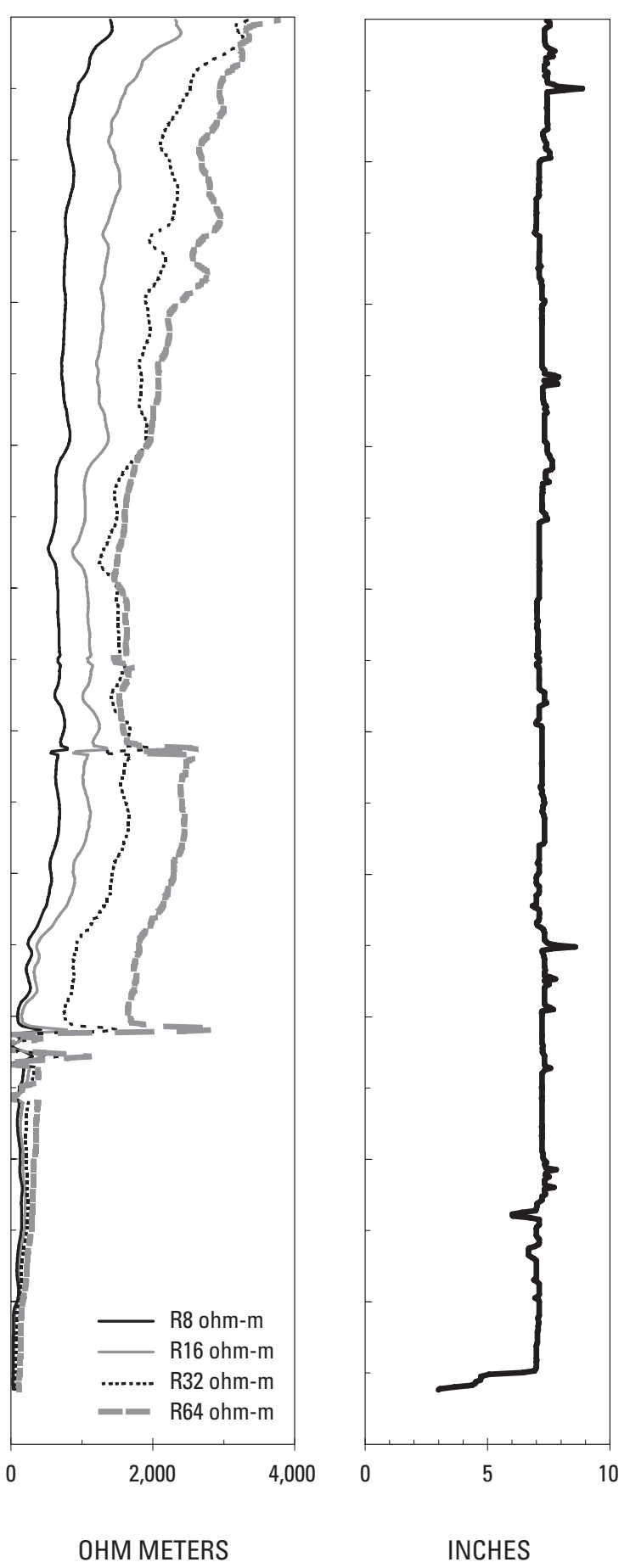

Figure 1-5. Geophysical logs of MB TB-1 (Well number 051597). 
MB TB-1 Boring Log (Well Number 051597, location shown on figure 13.)

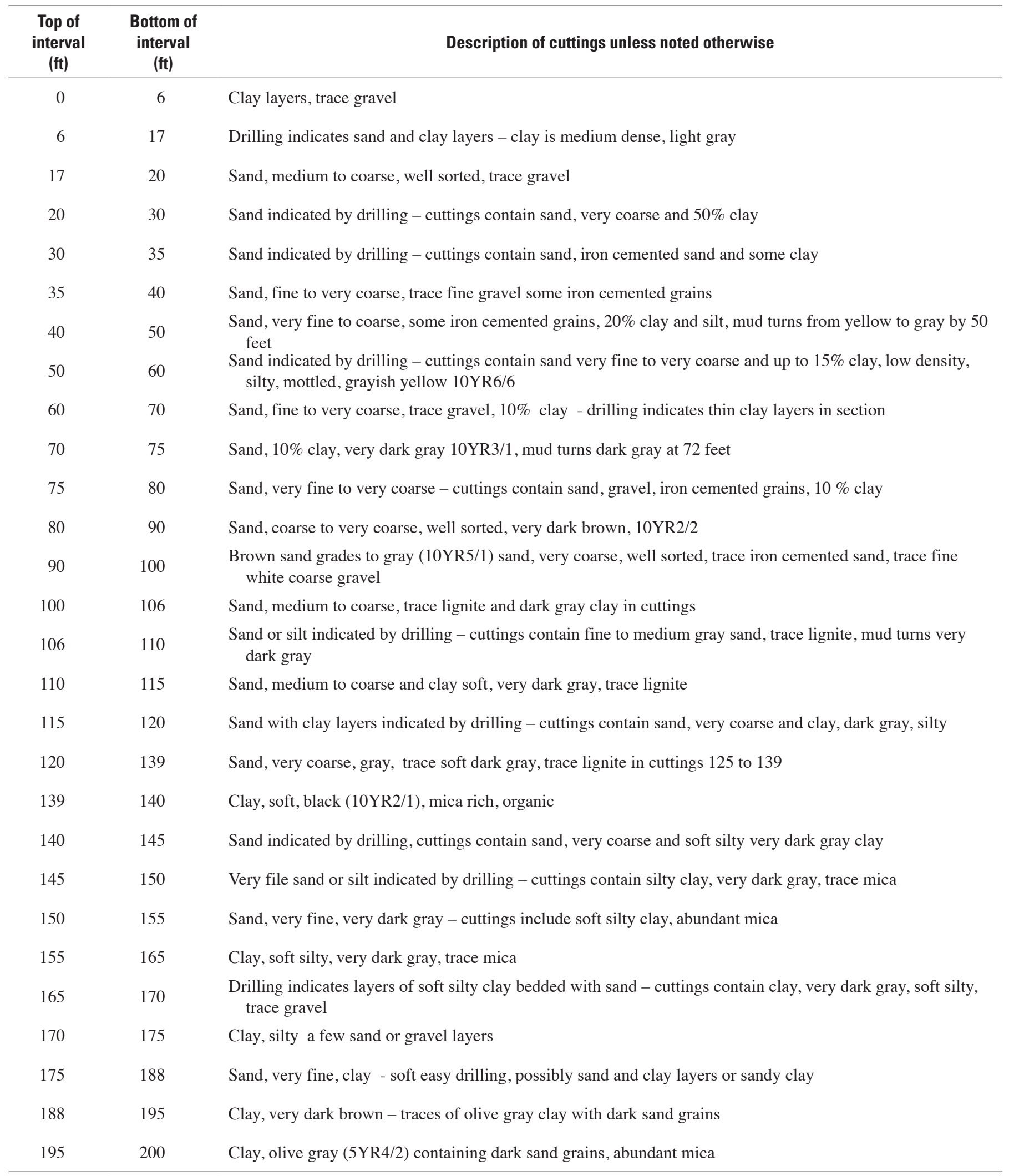


Boring logs for the five shallow wells completed in the upland areas of the McDonalds Branch basin.

MB UP-1 (Well Number 051589, location shown on figure 13.)

\begin{tabular}{ccl}
$\begin{array}{c}\text { Top of } \\
\text { interval } \\
(\mathbf{f t})\end{array}$ & $\begin{array}{c}\text { Bottom of } \\
\text { interval } \\
(\mathbf{f t})\end{array}$ & \\
\hline 0 & 5 & Sand, fine to coarse, trace gravel \\
5 & 16 & Sand, fine to very coarse, gravel $(20 \%)$, trace iron cemented sand, trace clay, mud color change to yellow \\
16 & 20 & Sand, medium to very coarse, $(20 \%)$ iron cemented sand, trace clay, mud color change to brown \\
20 & 27 & Sand, medium to coarse grained, tan, trace clay \\
\hline
\end{tabular}

MB UP-2 (Well Number 051587, location shown on figure 13.)

\begin{tabular}{|c|c|c|}
\hline $\begin{array}{c}\text { Top of } \\
\text { interval } \\
\text { (ft) }\end{array}$ & $\begin{array}{c}\text { Bottom of } \\
\text { interval } \\
\text { (ft) }\end{array}$ & Description of cuttings unless noted otherwise \\
\hline 0 & 5 & Sand, medium to coarse \\
\hline 5 & 15 & Sand, medium to coarse, and clay, sandy, yellow \\
\hline 15 & 20 & Sand, coarse to very coarse, with fine to medium gravel, layer of iron cemented sand at 17 feet \\
\hline 20 & 22 & Sand, coarse to very coarse, with fine to medium gravel \\
\hline 22 & 23 & Clay, light gray, silty with very fine sand, medium dense \\
\hline 23 & 24 & Clay, very dark grayish brown (10YR 3/2), silty \\
\hline
\end{tabular}

MB UP-3 (Well Number 051592, location shown on figure 13.)

\begin{tabular}{|c|c|c|}
\hline $\begin{array}{c}\text { Top of } \\
\text { interval } \\
\text { (ft) }\end{array}$ & $\begin{array}{c}\text { Bottom of } \\
\text { interval } \\
\text { (ft) }\end{array}$ & Description of cuttings unless noted otherwise \\
\hline 0 & 7 & Sand and gravel, yellowish brown, clay (20\%), yellow, sandy \\
\hline 7 & 10 & Sand and gravel, fine to medium, some clayey sand in cuttings \\
\hline 10 & 19 & $\begin{array}{l}\text { Sand and gravel, fine to medium, some clayey sand in cuttings with stringers of medium to coarse iron } \\
\text { cemented sand }\end{array}$ \\
\hline 19 & 20 & Clay, sandy, silty, very soft, contains $60 \%$ sand \\
\hline 20 & 24 & Clay, sandy, silty, very soft, contains $60 \%$ sand \\
\hline 24 & 32 & Sand, medium to coarse, well sorted, gravel at 31 feet, contains iron cemented sand \\
\hline
\end{tabular}

MB UP-4 (Well Number 051595, location shown on figure 13.)

\begin{tabular}{|c|c|c|}
\hline $\begin{array}{l}\text { Top of } \\
\text { interval } \\
\text { (ft) }\end{array}$ & $\begin{array}{c}\text { Bottom of } \\
\text { interval } \\
\text { (ft) }\end{array}$ & Description of cuttings unless noted otherwise \\
\hline 0 & 8 & Sand and gravel \\
\hline 8 & 11 & Clay, soft, sandy \\
\hline 11 & 20 & Sand, medium to very coarse and gravel, fine to medium \\
\hline 20 & 27 & Sand, tan, medium to coarse, well sorted, trace very coarse grains \\
\hline
\end{tabular}

MB UP-5 (051596, location shown on figure 13.)

\begin{tabular}{|c|c|c|}
\hline $\begin{array}{l}\text { Top of } \\
\text { interval } \\
\text { (ft) }\end{array}$ & $\begin{array}{c}\text { Bottom of } \\
\text { interval } \\
\text { (ft) }\end{array}$ & Description of cuttings unless noted otherwise \\
\hline 0 & 20 & Sand, coarse to very coarse with clay layers \\
\hline 20 & 40 & Sand fine to very coarse, trace clay in cuttings \\
\hline
\end{tabular}


Shallow borings completed in the McDonalds Branch basin using Geoprobe ${ }^{\circledR}$ sediment sampling equipment and used as ground truth for analyzing the GPR survey lines.

MDB-B1 (Well Number 051550, location shown on figure 19.)

\begin{tabular}{ccl}
\hline $\begin{array}{c}\text { Top of } \\
\text { interval } \\
(\mathbf{f t})\end{array}$ & $\begin{array}{c}\text { Bottom of } \\
\text { interval } \\
(\mathbf{f t})\end{array}$ & \\
\hline 0 & 6.0 & Sand, fine to coarse grained \\
6.0 & 6.2 & Clay \\
6.2 & 7.5 & Sand, very fine grained \\
8.6 & 9.2 & Sandy clay \\
9.2 & 11.5 & Sand, fine grained, with some clay in matrix, saturated at 11.5 \\
11.5 & 15.5 & Sand, medium to fine grained, trace clay in layers \\
15.5 & 16.1 & Clay with some thin sand stringers \\
16.1 & 19.5 & Clay, organic rich \\
19.5 & 19.6 & Sand layer \\
19.6 & 22.5 & Clay, organic rich \\
22.5 & 27.5 & Sand, fine to coarse grained \\
\hline
\end{tabular}

MDB-B2 (Well Number 051551, location shown on figure 19.)

\begin{tabular}{ccl}
\hline $\begin{array}{c}\text { Top of } \\
\text { interval } \\
(\mathbf{f t})\end{array}$ & $\begin{array}{c}\text { Bottom of } \\
\text { interval } \\
(\mathbf{f t})\end{array}$ & \\
\hline 0 & 8 & Sand, fine to coarse grained, saturated at 6 feet \\
8 & 9 & Clay \\
9 & 15.1 & Sand, medium to fine grained \\
15.1 & 19.1 & Sand, very fine to coarse grained \\
\hline
\end{tabular}

MDB-B3 (Well Number 051552, location shown on figure 19.)

\begin{tabular}{ccl}
\hline $\begin{array}{c}\text { Top of } \\
\text { interval } \\
(\mathbf{f t})\end{array}$ & $\begin{array}{c}\text { Bottom of } \\
\text { interval } \\
(\mathbf{f t})\end{array}$ & \\
\hline 0 & 1.5 & Sand, fine grained \\
1.7 & 2.3 & Sand, some silt and clay \\
3.5 & 6.9 & Sand with some clay, saturated at 3.5 feet \\
7.5 & 15.5 & Sand, very fine to fine grained, some clay \\
\hline
\end{tabular}

MDB-B4 (Well Number 051554, location shown on figure 19.)

\begin{tabular}{ccl}
\hline $\begin{array}{c}\text { Top of } \\
\text { interval } \\
(\mathbf{f t})\end{array}$ & $\begin{array}{c}\text { Bottom of } \\
\text { interval } \\
(\mathbf{f t})\end{array}$ & \multicolumn{1}{c}{ Description of sediments from core samples } \\
\hline 0 & 11.4 & Sand, fine, with some very fine and medium grained sand \\
11.4 & 15.4 & Sand, very fine, well sorted grading to poorly sorted at 15.2 feet \\
15.4 & 19.4 & Sand, medium and fine grained \\
\hline
\end{tabular}


Shallow borings completed in the McDonalds Branch basin using Geoprobe ${ }^{\circledR}$ sediment sampling equipment and used as ground truth for analyzing the GPR survey lines.-Continued

MDB-B5 (Well Number 051555, location shown on figure 19.)

\begin{tabular}{|c|c|c|}
\hline $\begin{array}{l}\text { Top of } \\
\text { interval } \\
\text { (ft) }\end{array}$ & $\begin{array}{c}\text { Bottom of } \\
\text { interval } \\
\text { (ft) }\end{array}$ & Description of sediments from core samples \\
\hline 0 & 3.4 & Sand and gravel \\
\hline 3.4 & 11.4 & Sand, medium grained, saturated at 8 feet \\
\hline 11.4 & 15.4 & Sand, coarse, grading to medium and some fine sand at base, clay 13.8 to 14.0 \\
\hline 15.4 & 17.5 & Sand, medium and some fine sand \\
\hline 17.5 & 19.4 & Sand, coarse \\
\hline
\end{tabular}

MDB-B6 (Well Number 051553, location shown on figure 19.)

\begin{tabular}{ccl}
\hline $\begin{array}{c}\text { Top of } \\
\text { interval } \\
(\mathbf{f t})\end{array}$ & $\begin{array}{c}\text { Bottom of } \\
\text { interval } \\
(\mathbf{f t})\end{array}$ & \\
\hline 0 & 7.8 & Sand, fine grained, little gravel, trace silt and clay \\
7.8 & 9.4 & Silt, clay and sand, fine grained \\
9.4 & 12.0 & Layers of clay, silt and fine sand \\
12 & 13.1 & Sandy clay, with clay layers, saturated at 12.7 feet \\
13.1 & 16 & Sand, medium with some fine grains \\
16 & 20 & Sand, medium to fine, grading to coarse sand with some gravel at 20 feet \\
20 & 24 & Sand, medium with some fine sand, trace coarse sand near 24 feet \\
24 & 28 & Sand, fine and medium trace silt \\
\hline
\end{tabular}



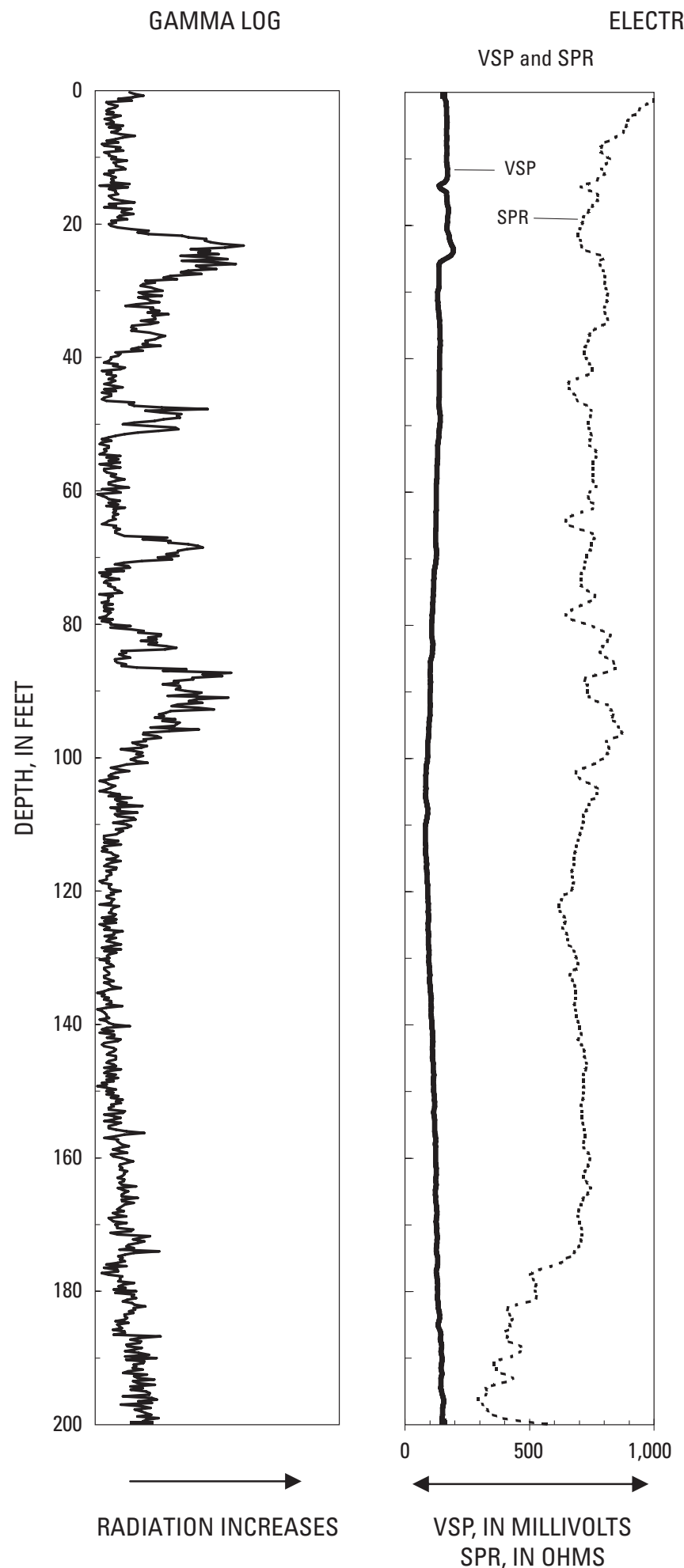

RESISTIVITY

CALIPER LOG
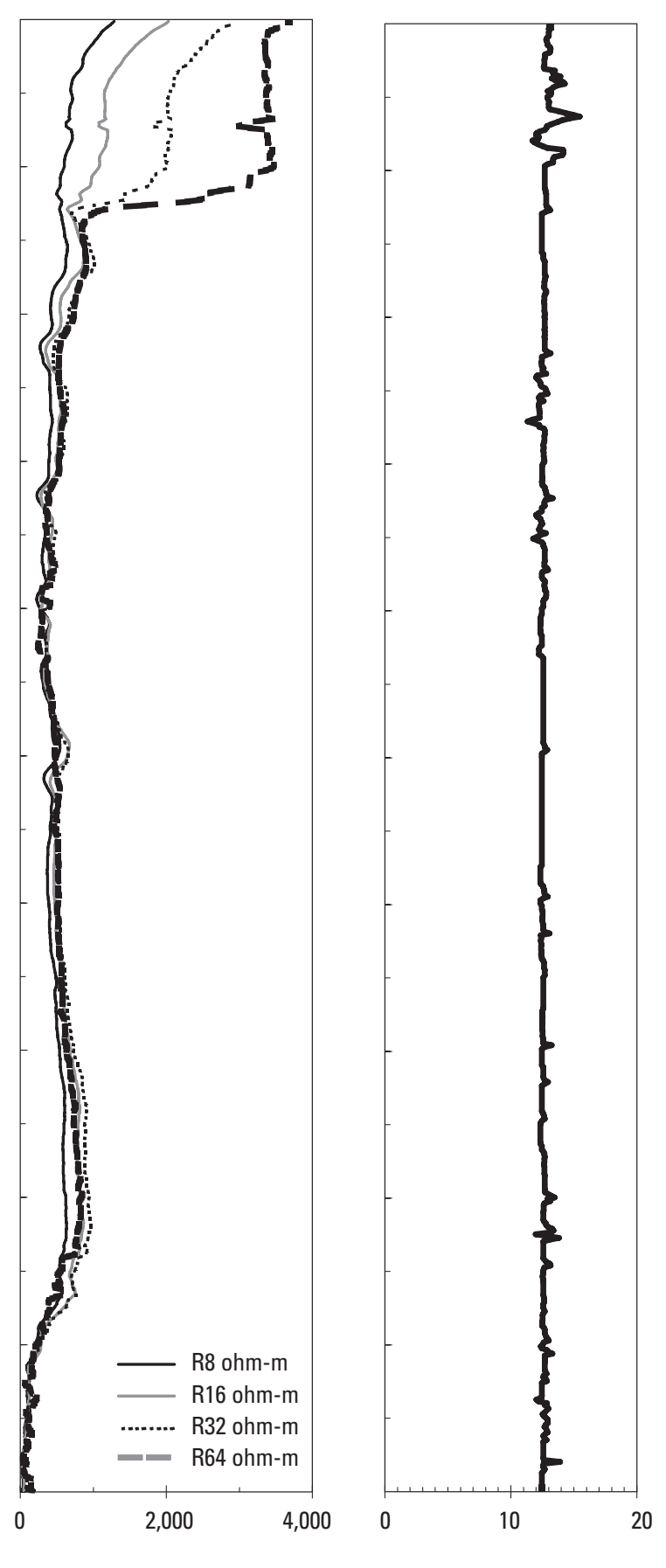

OHM METERS

INCHES

Figure 1-6. Geophysical logs of MM OW-1D (Well number 011499). 
MM OW-1D Boring Log (Well Number 011499, location shown on figure 20.)

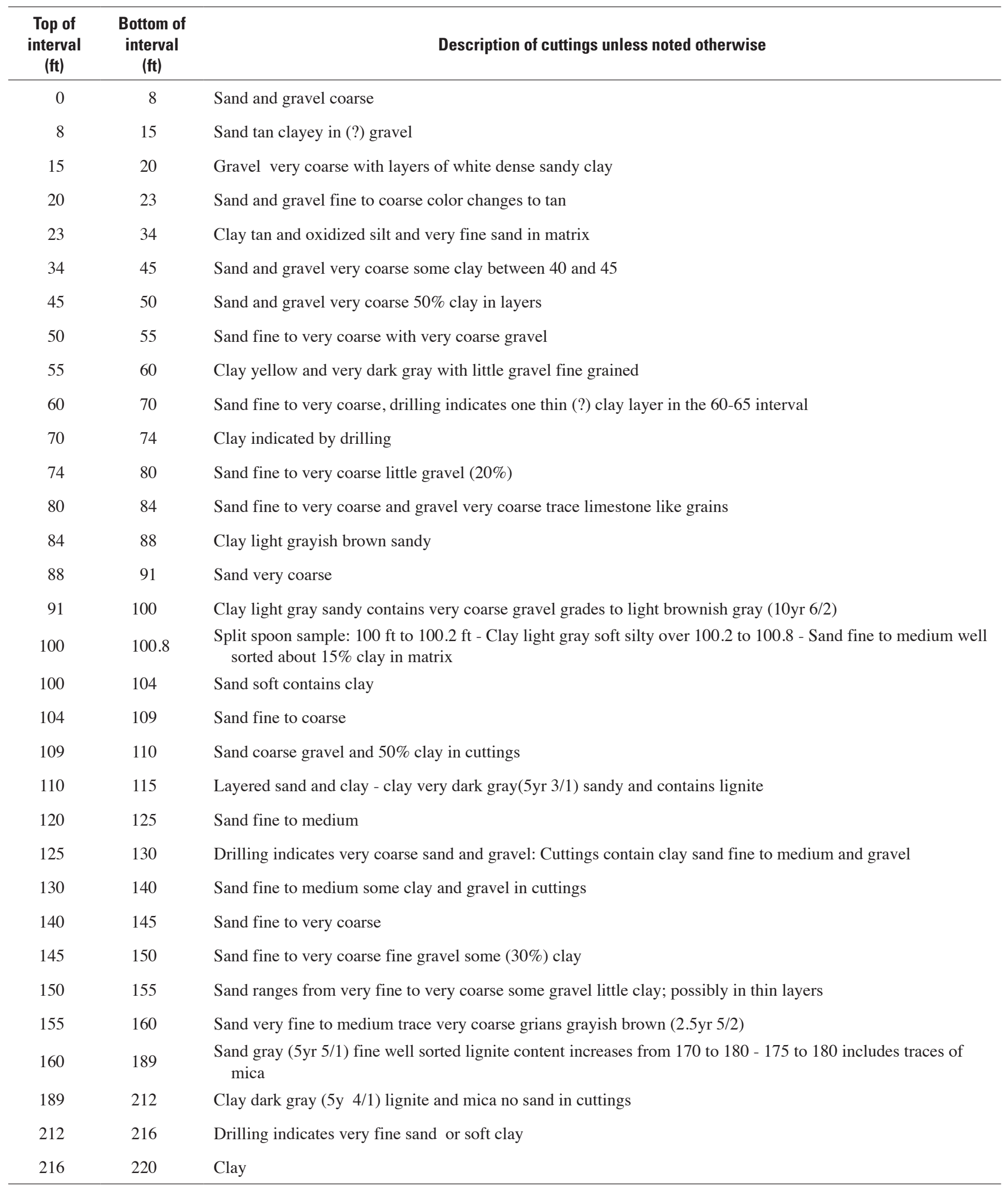




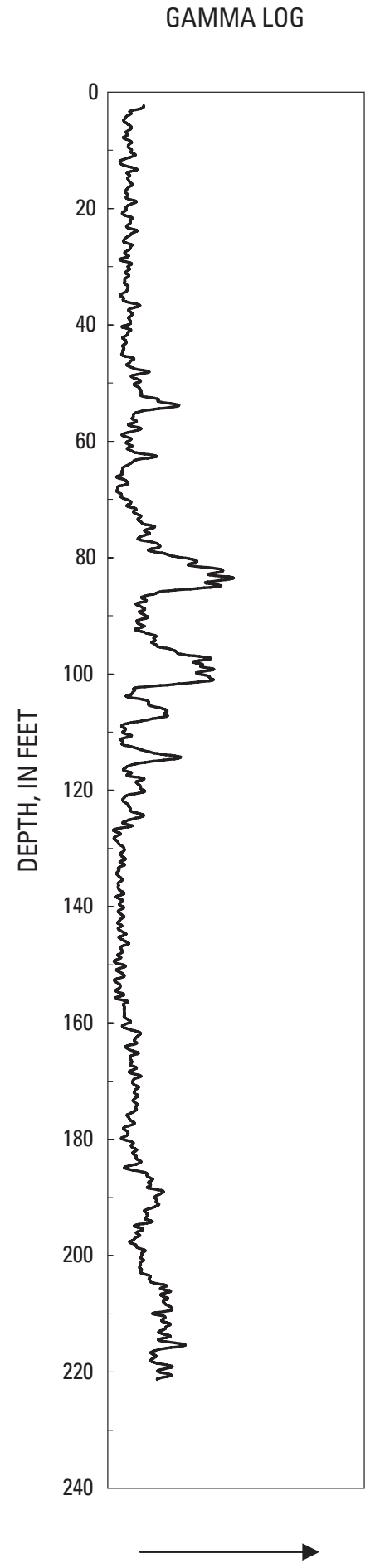

RADIATION INCREASES

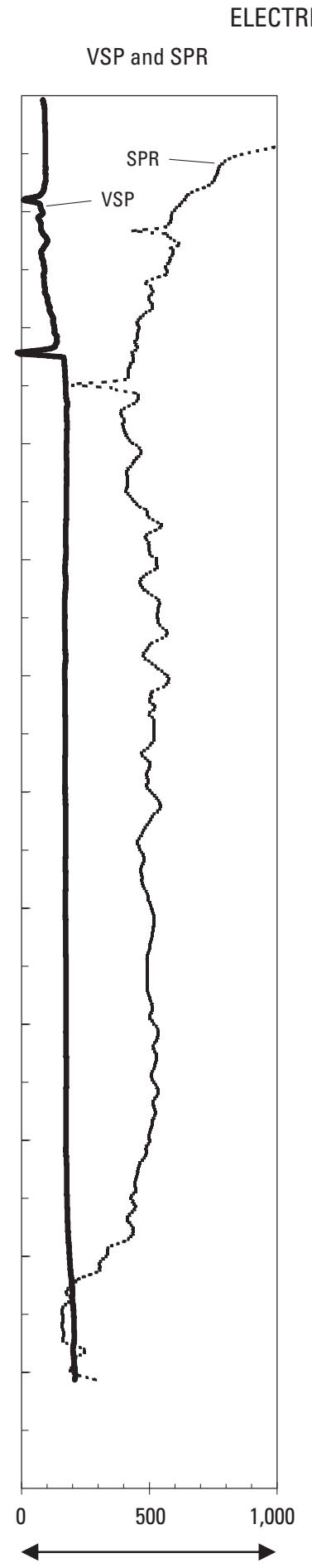

VSP, IN MILLIVOLTS SPR, IN OHMS

\section{RESISTIVITY}

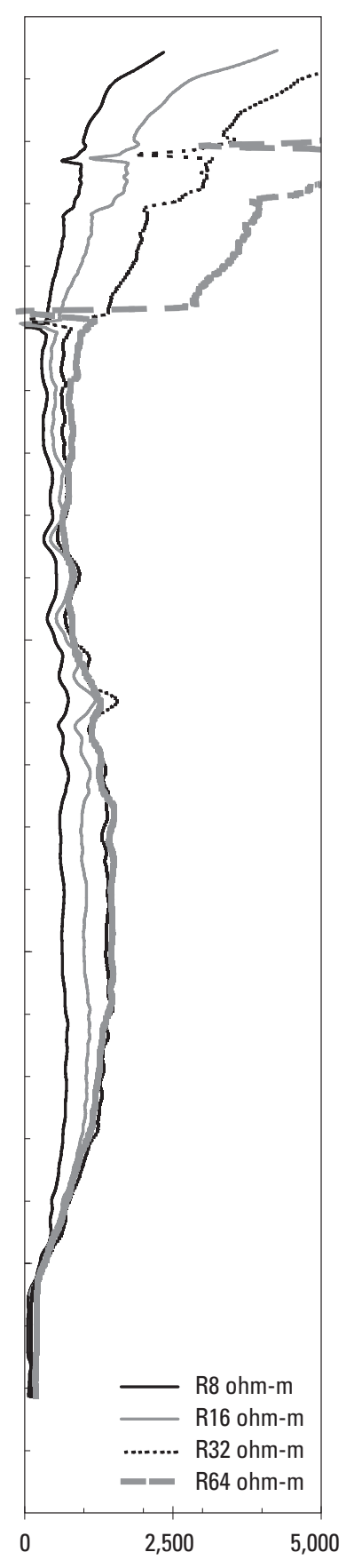

OHM METERS
CALIPER LOG

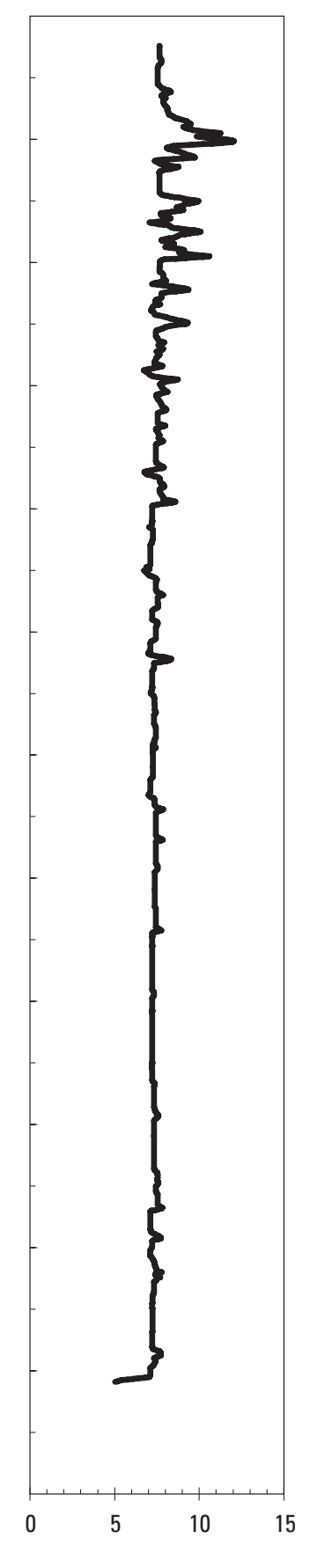

INCHES

Figure 1-7. Geophysical logs of MM OW-2D (Well number 011503). 
MM OW-2D Boring Log (Well Number 011503, location shown on figure 20.)

\begin{tabular}{|c|c|c|}
\hline $\begin{array}{l}\text { Top of } \\
\text { interval } \\
\text { (ft) }\end{array}$ & $\begin{array}{c}\text { Bottom of } \\
\text { interval } \\
\text { (ft) }\end{array}$ & Description of cuttings unless noted otherwise \\
\hline 20 & 25 & Sand medium to very coarse trace clay \\
\hline 25 & 30 & Sand medium to very coarse little clay $(20 \%)$ \\
\hline 35 & 40 & Sand medium to very coarse - drilling indicates no clay from $20-40 \mathrm{ft}$ \\
\hline 40 & 60 & Sand and gravel very coarse trace clay $20 \%$ friable limestone like gravel size pieces \\
\hline 60 & 74 & Sand and gravel very coarse limestone like pieces little (20\%) sandy clay \\
\hline 74 & 76 & Clay sandy brownish yellow (10YR 6/8) \\
\hline 74 & 80 & Sand fine to very coarse little gravel (20\%) \\
\hline 80 & 98 & Clay very pale brown sandy soft and sand and gravel color change to darker brown at 89 feet \\
\hline 98 & 100 & Clay dark gray (7.5YR 4/0) sandy and clay gray (10YR 6/1) fine sand in martix \\
\hline 100 & 108 & Sand and clay layers Rod change at 100 feet indicated 4 feet of wash in bottom hole \\
\hline 108 & 115 & Sand very fine cuttings contain clay \\
\hline 115 & 120 & Clay very dark brown (10YR 2/1) \\
\hline 120 & 130 & Drilling indicates sand cuttings contain sand medium and up to $50 \%$ clay \\
\hline 125 & 130 & Drilling indicates sand cuttings contain sand medium little clay \\
\hline 135 & 140 & Sand fine to medium driller indicates sand but some clay in cuttings \\
\hline 140 & 145 & Sand tan fine to very coarse \\
\hline 145 & 150 & Sand tan medium to very coarse \\
\hline 150 & 155 & Sand coarse to very coarse fine gravel trace clay in cuttings \\
\hline 155 & 160 & Sand coarse to very coarse fine gravel trace dark gray silt stone \\
\hline 160 & 170 & Sand tan fine to very coarse trace black grains and white friable hard clay like minerals \\
\hline 170 & 175 & Sand indicated by drilling; cuttings contain coarse to very coarse sand trace dark gray sandy clay \\
\hline 175 & 180 & $\begin{array}{l}\text { Sand coarse to very coarse with fine gravel trace medium dark gray clay and white friable hard clay like } \\
\text { minerals }\end{array}$ \\
\hline 180 & 185 & $\begin{array}{l}\text { Sand indicated by drilling; cuttings contain little light and dark gray clay trace to } 15 \% \text { lignite and coarse to } \\
\text { very coarse sand }\end{array}$ \\
\hline 185 & 190 & Sand some clay and lignite \\
\hline
\end{tabular}


MM OW-2D Boring Log (Cont.) (Well Number 011503, location shown on figure 20.)—Continued

\begin{tabular}{ccl}
\hline $\begin{array}{c}\text { Top of } \\
\text { interval } \\
(\mathbf{f t})\end{array}$ & $\begin{array}{c}\text { Bottom of } \\
\text { interval } \\
(\mathbf{f t})\end{array}$ & \multicolumn{1}{c}{ Description of cuttings unless noted otherwise } \\
\hline 190 & 195 & Clay, gray, very soft organic 20\% lignite mud change color \\
195 & 200 & Sand fine and clay (50\%) dark gray lignite trace mica \\
200 & 209 & Sand very fine well sorted micaeous \\
209 & 216 & Clay, gray, soft, micaeous, easy drilling \\
216 & 220 & Clay with sand layers \\
220 & 225 & Sand grading to clay gray soft \\
225 & 230 & Clay very dark gray (5y 3/1), soft, contains silt \\
\hline
\end{tabular}





\section{Appendix 2}

Altitude, thickness, estimated sand content, and (or) horizontal hydraulic conductivity of hydrogeologic layers of the Kirkwood-Cohansey aquifer system, Albertson Brook study area and vicinity, New Jersey Pinelands. 


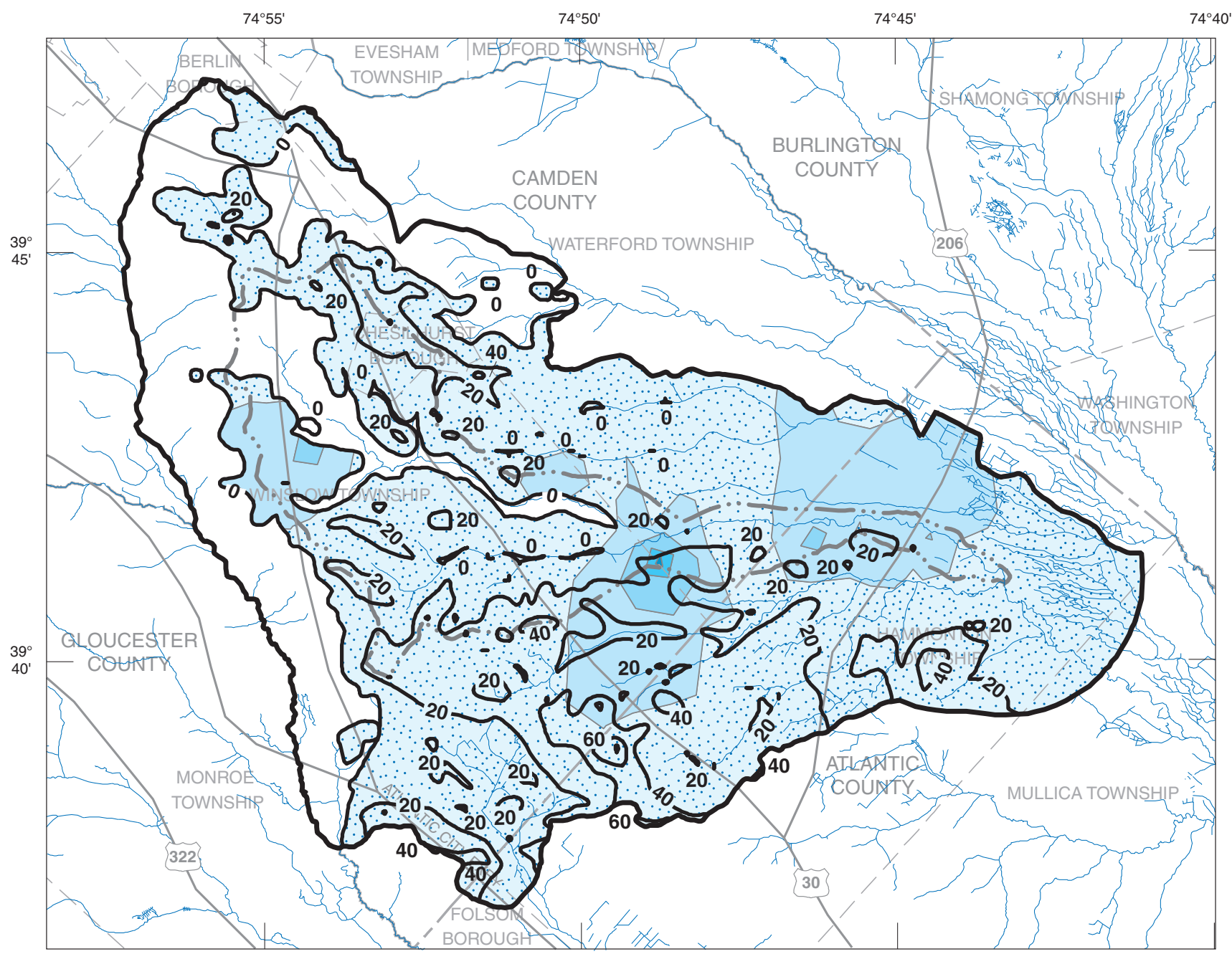

Base from U.S. Geological Survey digital line graph files, 1:24,000,

Universal Transverse Mercator projection, Zone 18, NAD83

EXPLANATION

\section{Estimated sand content in the}

$\mathrm{AB}$ A-1 aquifer layer

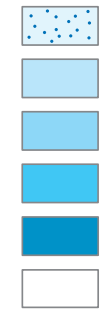

Mostly sand

More sand than clay

Sand and clay

More clay than sand

Mostly clay

Area beyond the extent of the $A B$ A-1 aquifer layer
- 20- LINE OF EQUAL THICKNESS-Shows thickness of the $A B$ A-1 aquifer layer, in feet. Contour interval 20 feet. Datum is NAVD 88

_ $\quad$ Albertson Brook drainage basin

Albertson Brook study area

Figure 2-1. Thickness and estimated sand content of the AB A-1 aquifer layer of the Kirkwood-Cohansey aquifer system, Albertson Brook study area and vicinity, New Jersey Pinelands. 


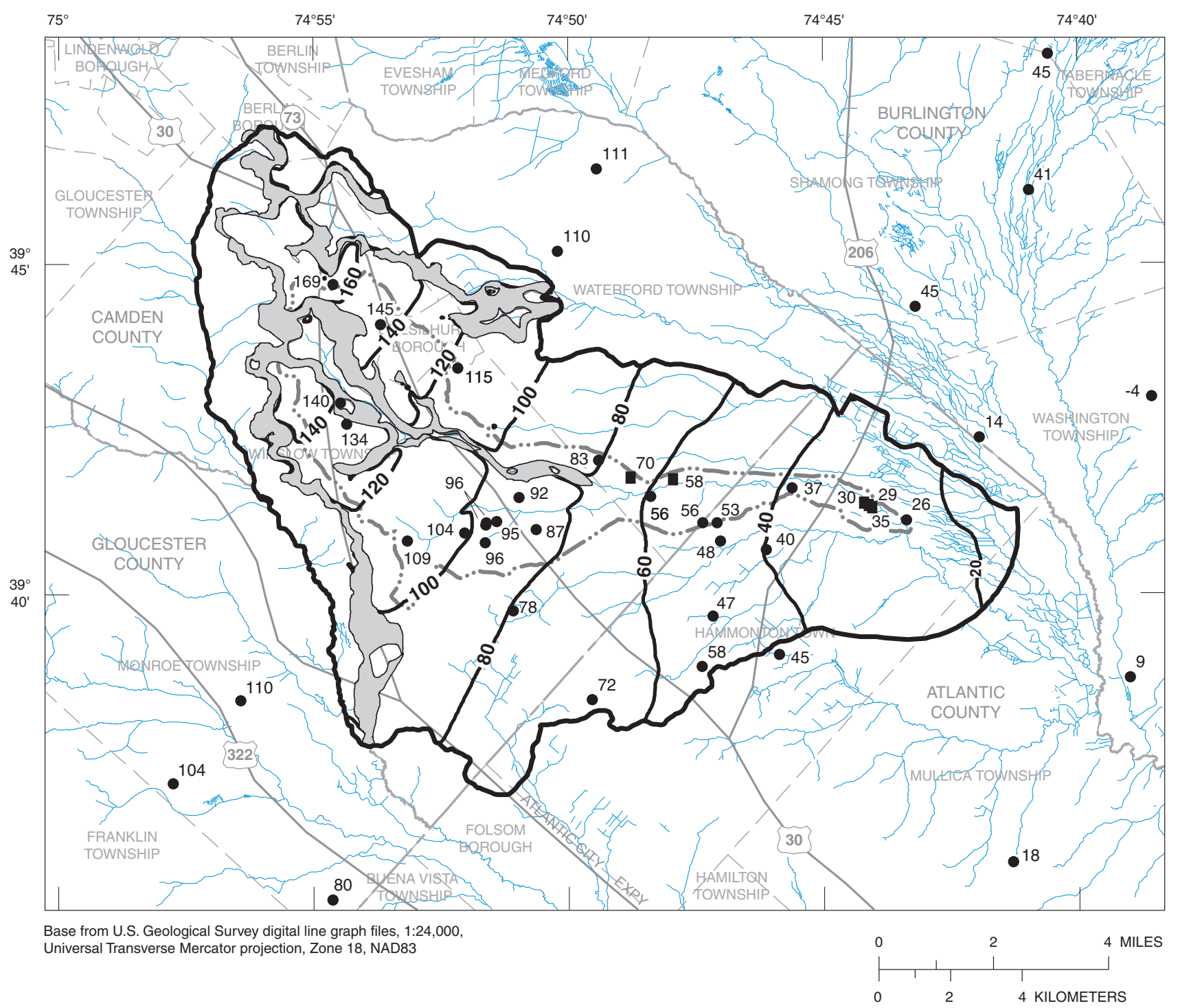

EXPLANATION

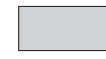

Outcrop area of the $A B A-1 C 1$ leaky confining layer of the Kirkwood-Cohansey aquifer system

-120- STRUCTURE CONTOUR-Shows approximate altitude of the top of the $A B A-1 C 1$ leaky confining layer, in feet. Contour interval 20 feet. Datum is NAVD 88

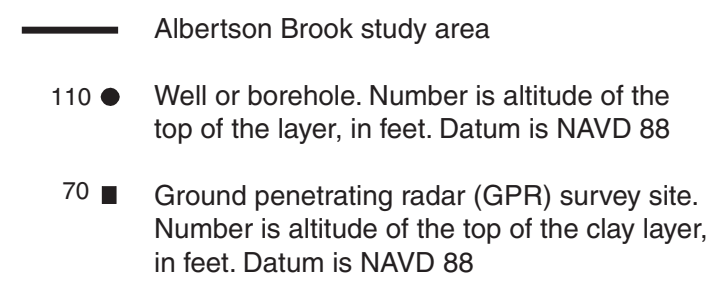
in feet. Datum is NAVD 88

Figure 2-2. Structure contours of the top of the $A B A-1 C 1$ leaky confining layer of the Kirkwood-Cohansey aquifer system, Albertson Brook study area and vicinity, New Jersey Pinelands. 


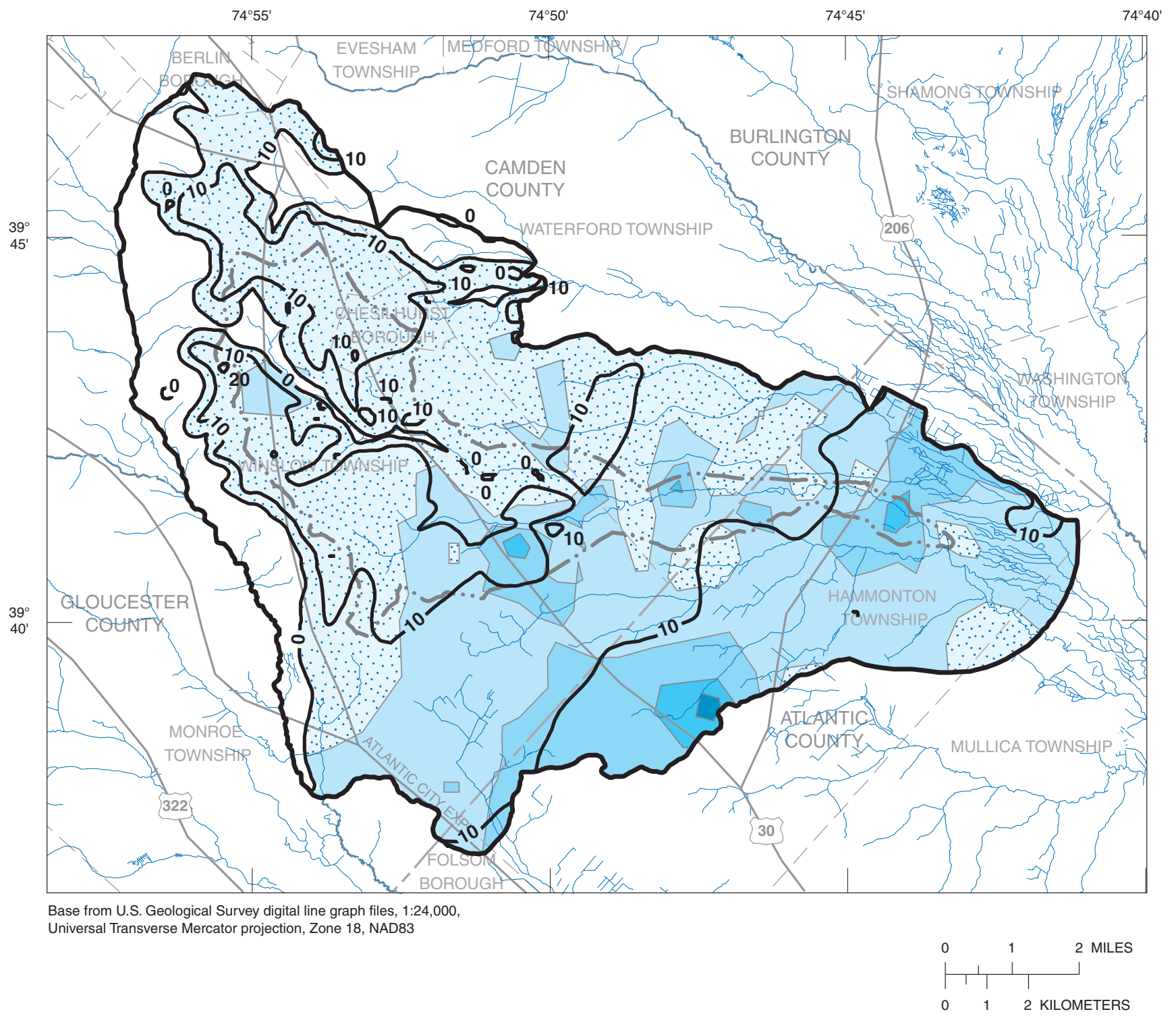

EXPLANATION

Estimated sand content in the AB A-1C1 leaky confining layer

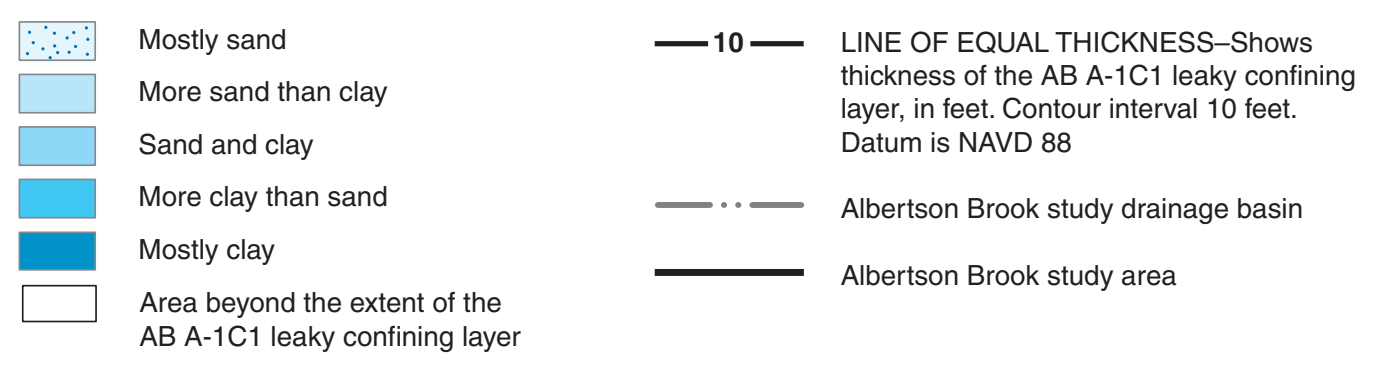

Figure 2-3. Thickness and estimated sand content of the AB A-1C1 leaky confining layer of the Kirkwood-Cohansey aquifer system, Albertson Brook study area and vicinity, New Jersey Pinelands. 


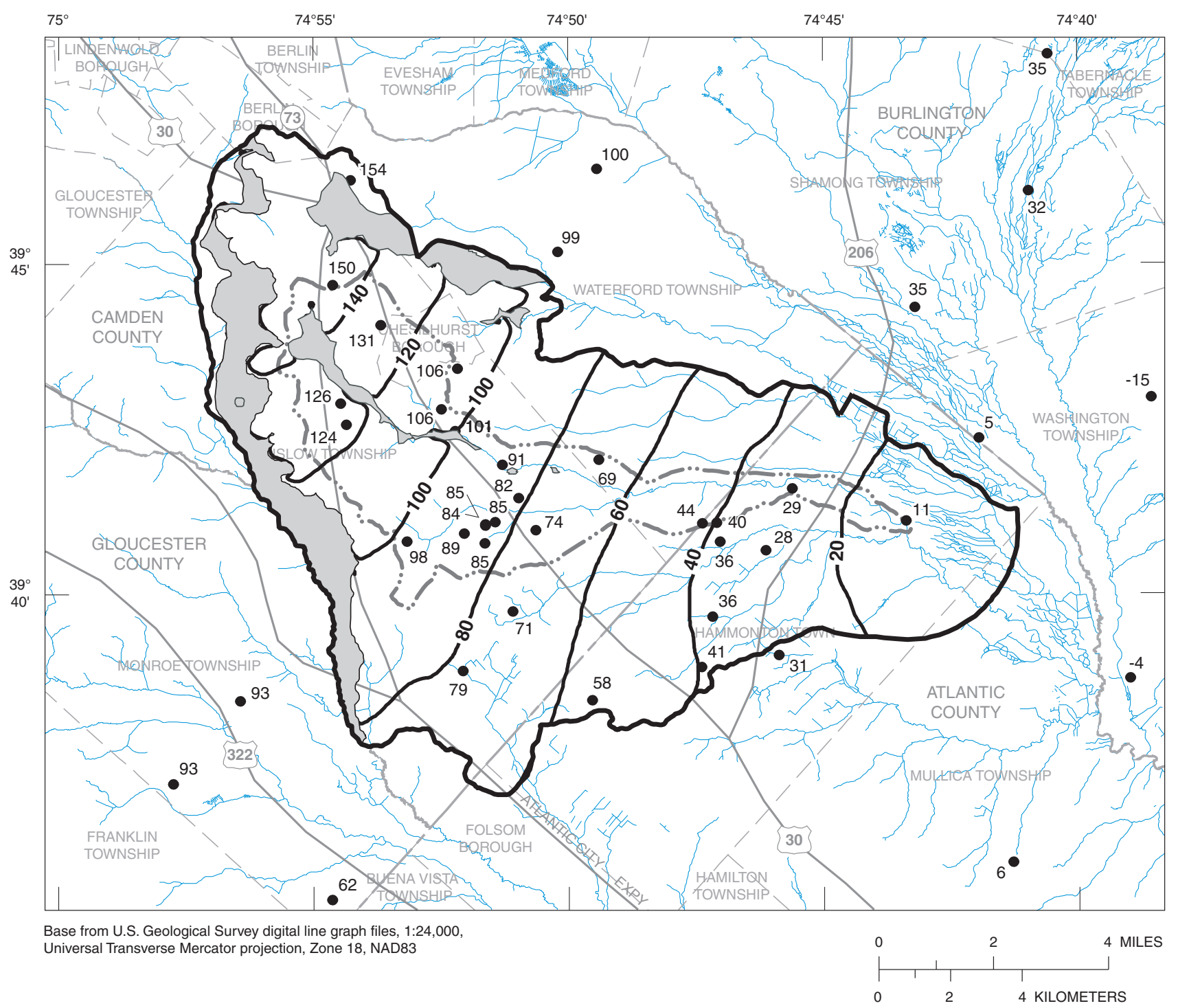

EXPLANATION

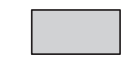

Outcrop area of the AB A-1B aquifer layer of the Kirkwood-Cohansey aquifer system

-120- STRUCTURE CONTOUR-Shows approximate altitude of the top of the AB A-1B aquifer layer, in feet. Contour interval 20 feet. Datum is NAVD 88

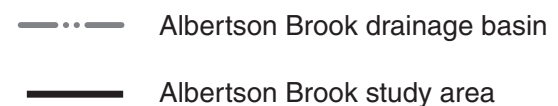

100 Well or borehole. Number is altitude of the top of the layer, in feet. Datum is NAVD 88

Figure 2-4. Structure contours of the top of the AB A-1B aquifer layer of the Kirkwood-Cohansey aquifer system, Albertson Brook study area and vicinity, New Jersey Pinelands. 


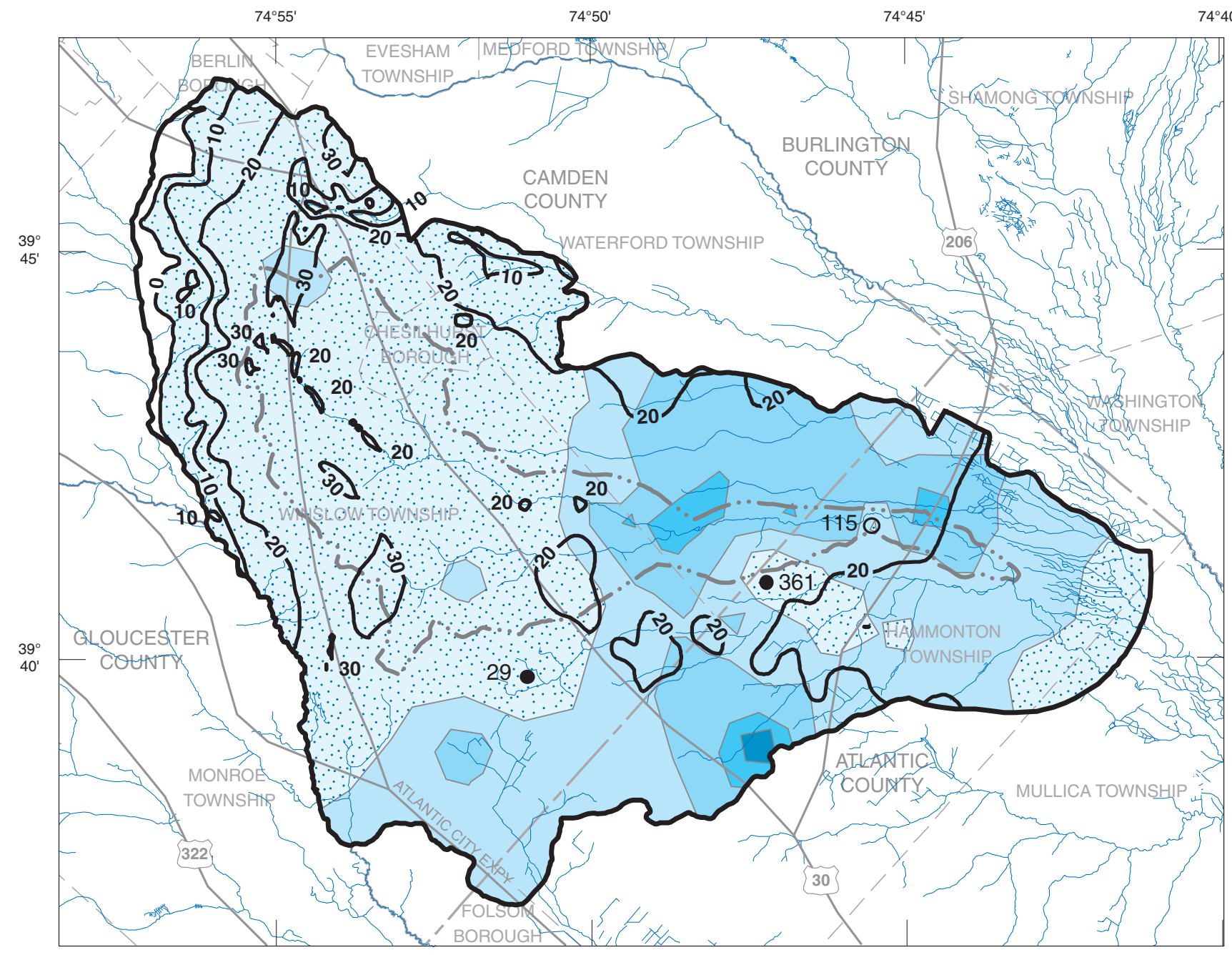

Base from U.S. Geological Survey digital line graph files, 1:24,000,

Universal Transverse Mercator projection, Zone 18, NAD83

\section{EXPLANATION}

Estimated sand content in the $A B$ A-1B aquifer layer

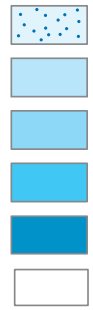

Mostly sand

More sand than clay

Sand and clay

More clay than sand

Mostly clay

Area beyond the extent of the AB A-1B aquifer layer

Albertson Brook study drainage basin

Albertson Brook study area

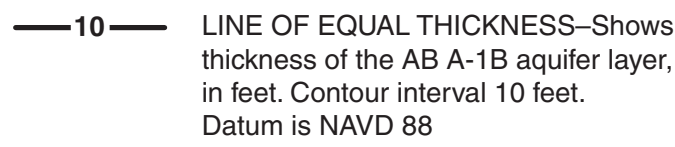

29 Estimated horizontal hydraulic conductivity (K) derived from well-performance data, number is $\mathrm{K}$ in feet per day. (table 4 )

Estimated horizontal hydraulic conductivity

1150 (K) derived from slug-test data, number is $\mathrm{K}$ in feet per day. (table 4)

Figure 2-5. Thickness, estimated sand content, and horizontal hydraulic conductivity of the AB A-1B aquifer layer of the KirkwoodCohansey aquifer system, Albertson Brook study area and vicinity, New Jersey Pinelands. 


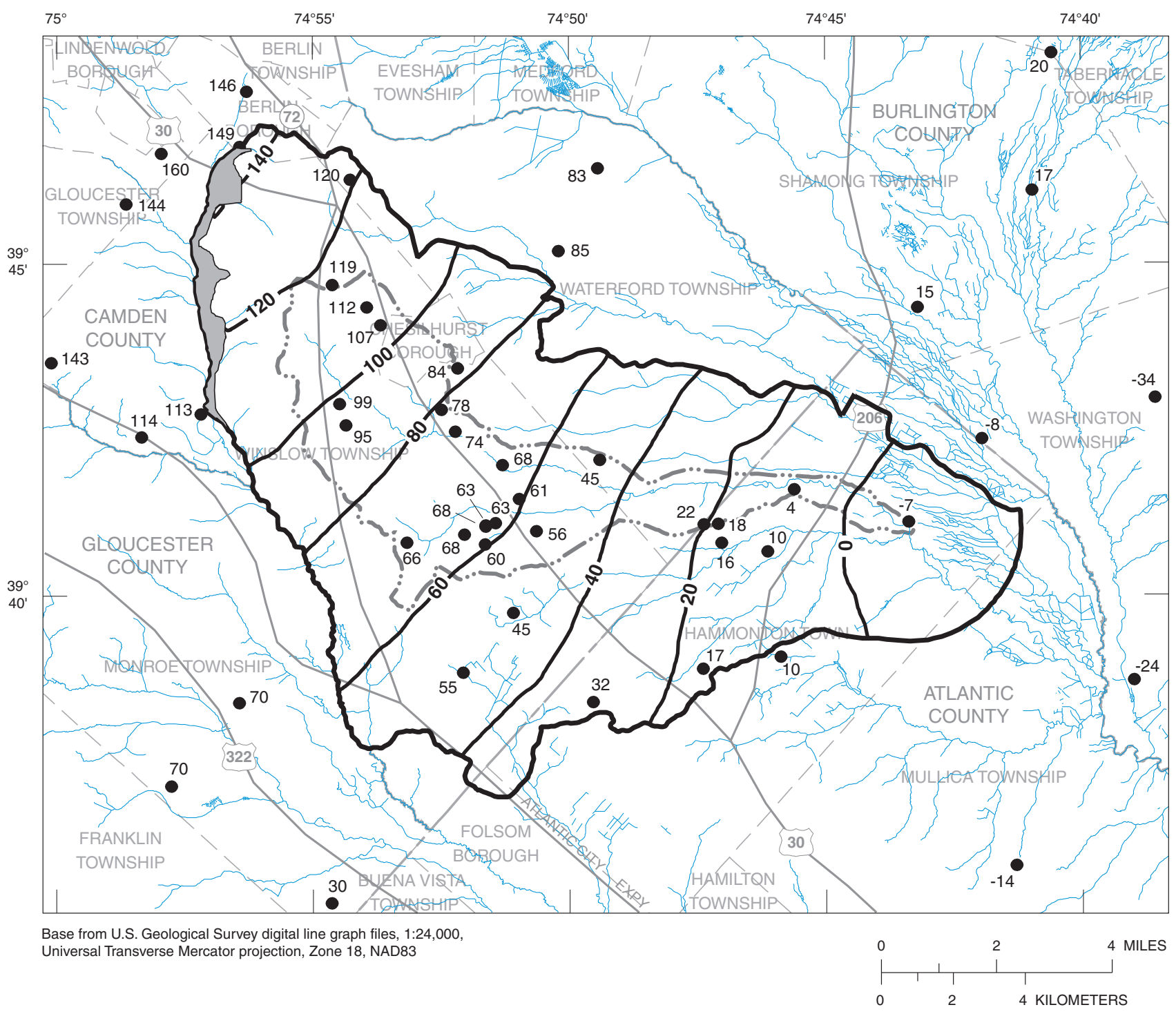

EXPLANATION

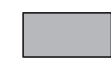

Outcrop area of the AB C-1 leaky confining layer of the Kirkwood-Cohansey aquifer system

-120- STRUCTURE CONTOUR-Shows approximate altitude of the top of the AB C-1 leaky confining layer, in feet. Contour interval 20 feet. Datum is NAVD 88

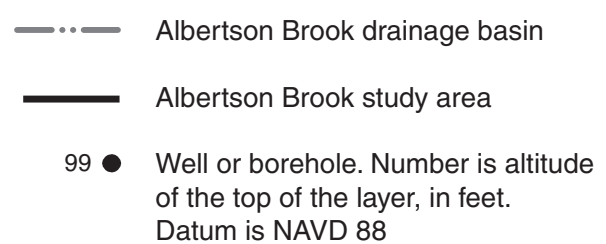

Datum is NAVD 88

Figure 2-6. Structure contours of the top of the AB C-1 leaky confining layer of the Kirkwood-Cohansey aquifer system, Albertson Brook study area and vicinity, New Jersey Pinelands. 


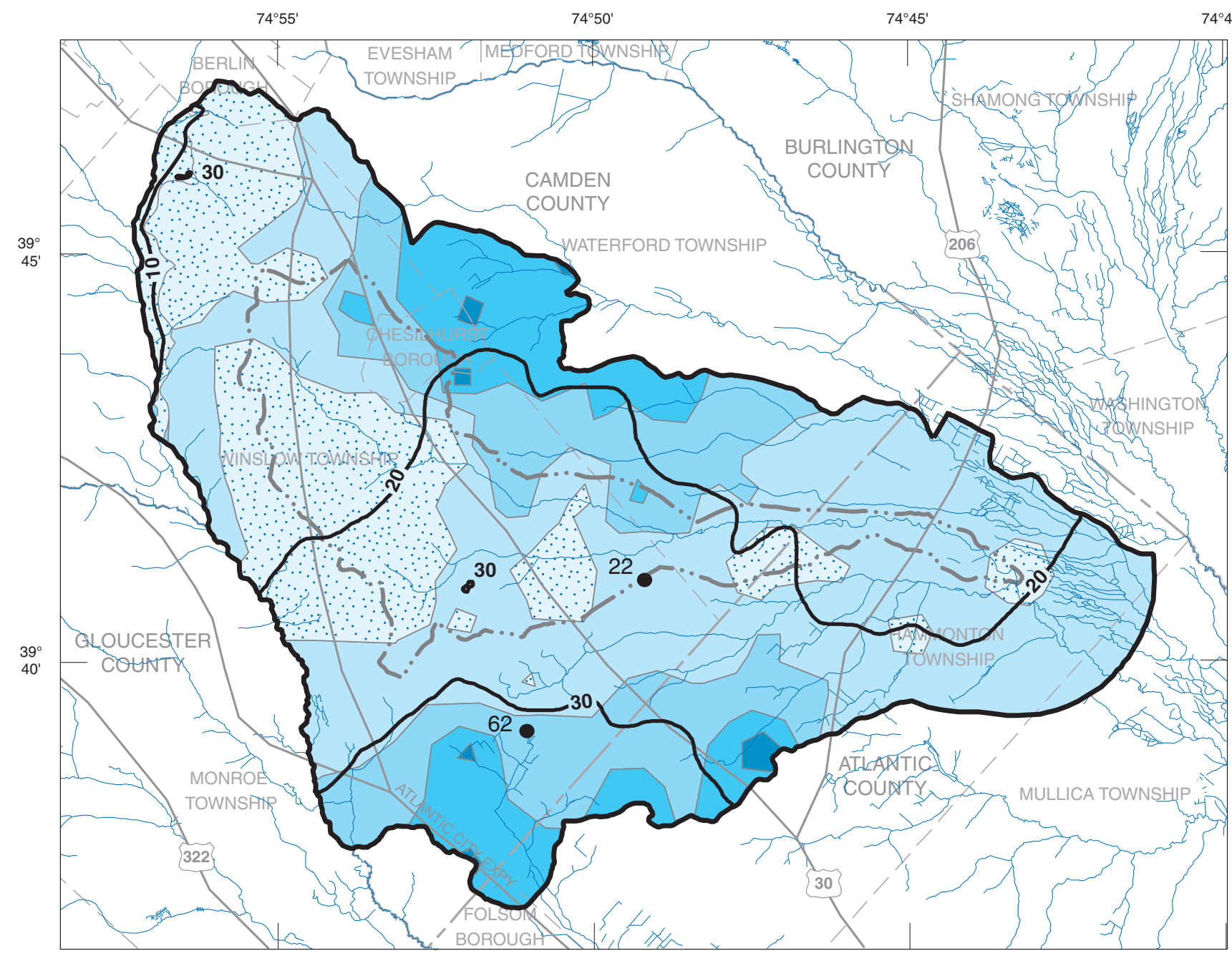

Base from U.S. Geological Survey digital line graph files, 1:24,000,

Universal Transverse Mercator projection, Zone 18, NAD83

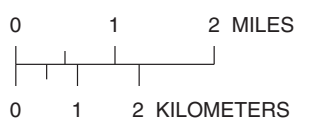

Estimated sand content in the $A B$-1 leaky confining layer

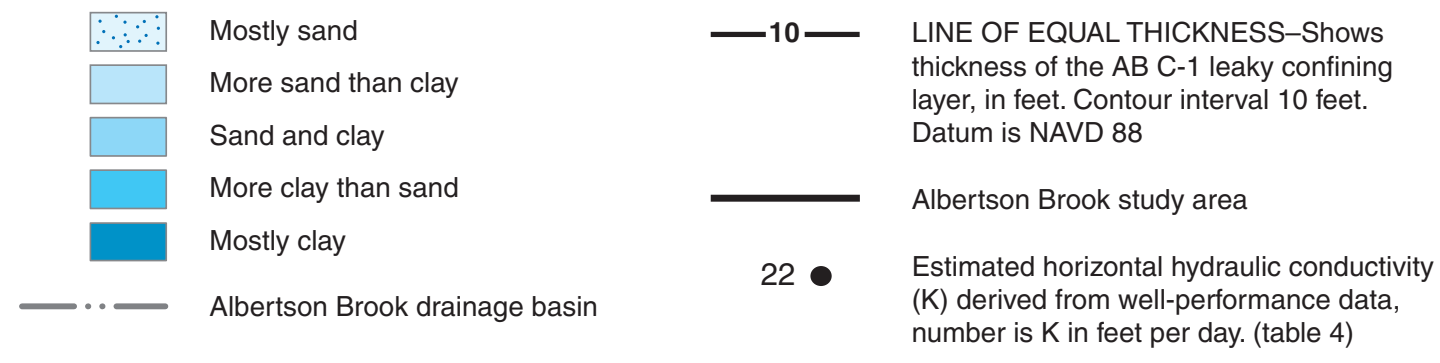

Figure 2-7. Thickness, estimated sand content, and horizontal hydraulic conductivity of the AB C-1 leaky confining layer of the Kirkwood-Cohansey aquifer system, Albertson Brook study area and vicinity, New Jersey Pinelands. 


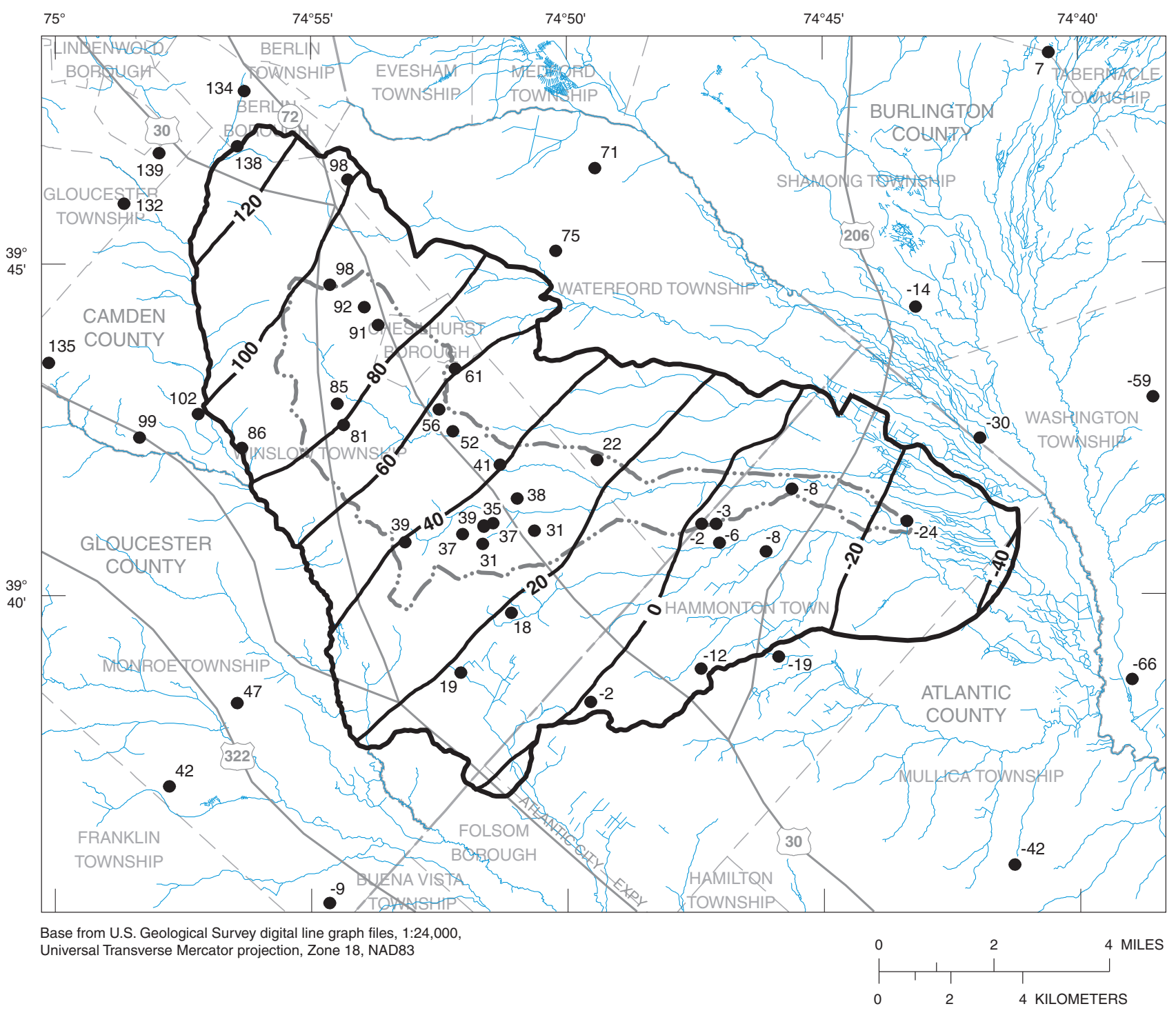

\section{EXPLANATION}

-20_STRUCTURE CONTOUR-Shows approximate altitude of the top of the AB A-2 aquifer layer, in feet. Contour interval 20 feet. Datum is NAVD 88

_.. Albertson Brook drainage basin

Albertson Brook study area

47 Well or borehole. Number is altitude of the top of the layer, in feet. Datum is NAVD 88

Figure 2-8. Structure contours of the top of the AB A-2 aquifer layer of the Kirkwood-Cohansey aquifer system, Albertson Brook study area and vicinity, New Jersey Pinelands. 


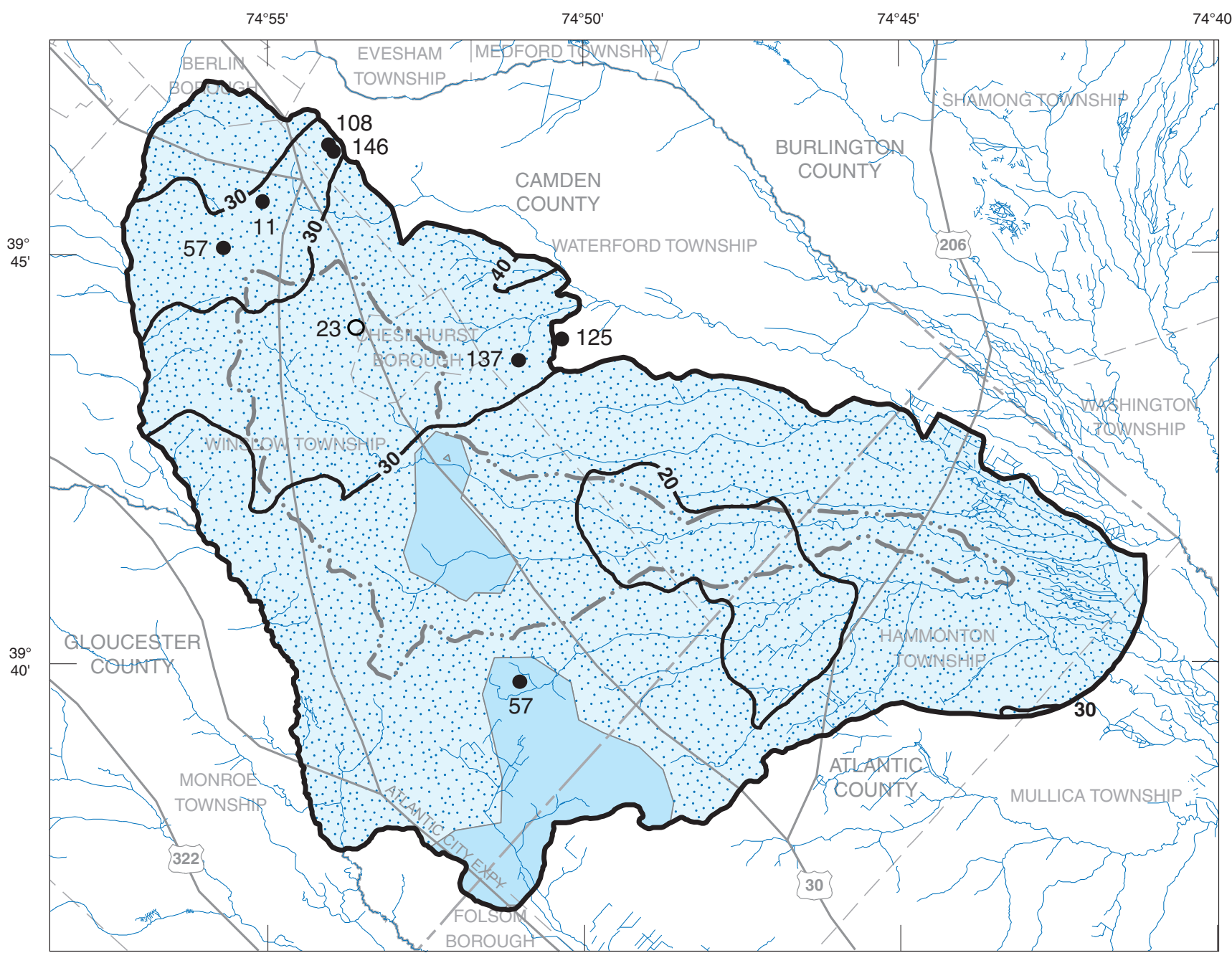

Base from U.S. Geological Survey digital line graph files, 1:24,000,

Universal Transverse Mercator projection, Zone 18, NAD83

\section{EXPLANATION}

\section{Estimated sand content in}

the $A B A-2$ aquifer layer

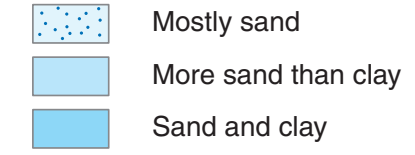

-20 - LINE OF EQUAL THICKNESS-Shows thickness of the AB A-2 aquifer layer, in feet. Contour interval 10 feet. Datum is NAVD 88

-.. Albertson Brook drainage basin

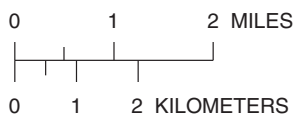

$\begin{array}{lll}0 & 1 & 2 \\ & \text { KILOMETERS }\end{array}$
57 Estimated horizontal hydraulic conductivity $(\mathrm{K})$ derived from slug-test data, number is $\mathrm{K}$ in feet per day. (table 4)

230
Estimated horizontal hydraulic conductivity (K) derived from well-performance data, number is $\mathrm{K}$ in feet per day. (table 4 )

Figure 2-9. Thickness, estimated sand content, and horizontal hydraulic conductivity of the AB A-2 aquifer layer of the KirkwoodCohansey aquifer system, Albertson Brook study area and vicinity, New Jersey Pinelands. 


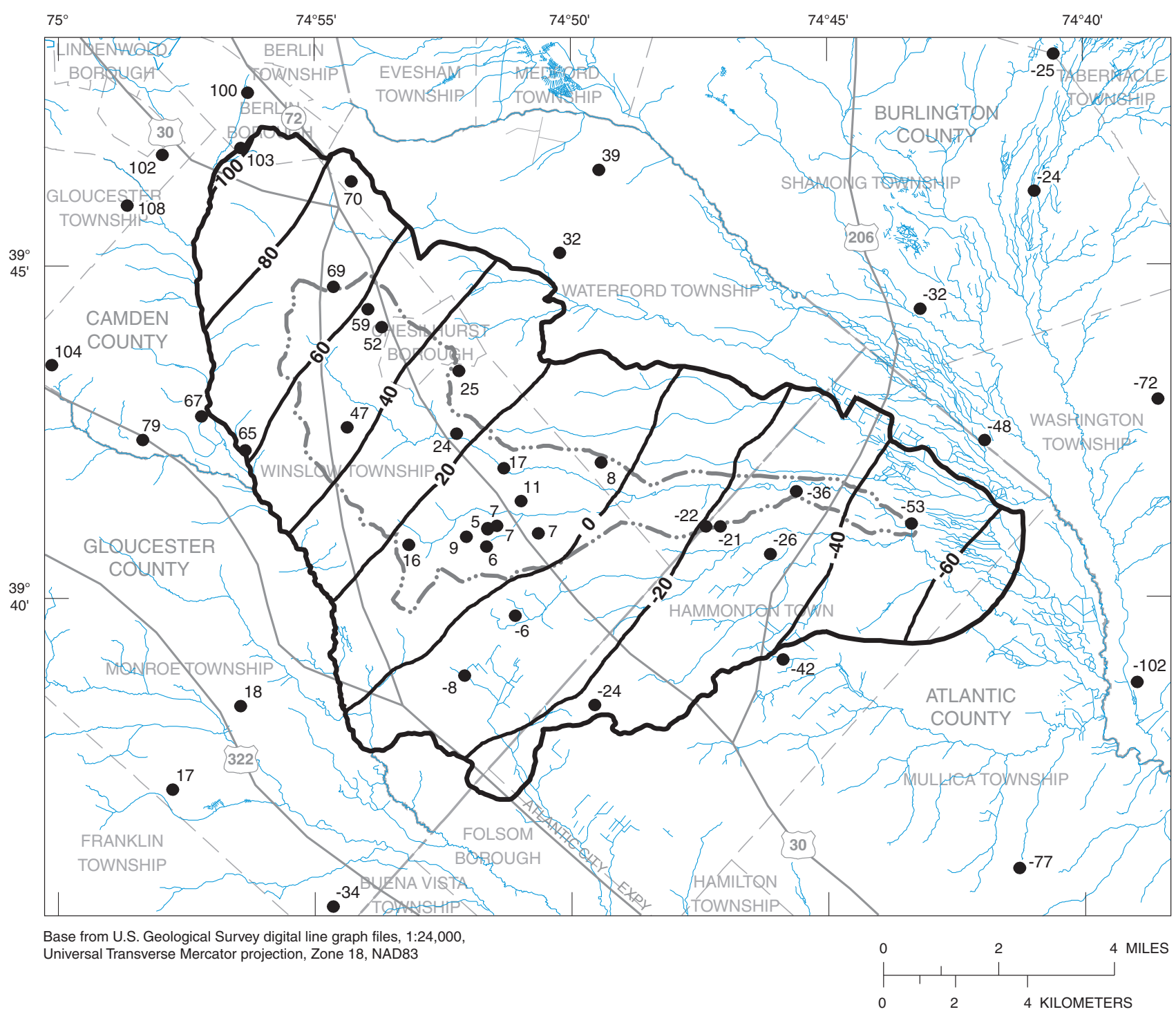

\section{EXPLANATION}

-20_STRUCTURE CONTOUR-Shows approximate altitude of the top of the AB C-2 leaky confining layer, in feet. Contour interval 20 feet. Datum is NAVD 88

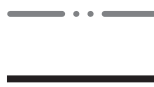

Albertson Brook drainage basin

Albertson Brook study area

99 Well or borehole. Number is altitude of the top of the layer, in feet. Datum is NAVD 88

Figure 2-10. Structure contours of the top of the AB C-2 leaky confining layer of the Kirkwood-Cohansey aquifer system, Albertson Brook study area and vicinity, New Jersey Pinelands. 


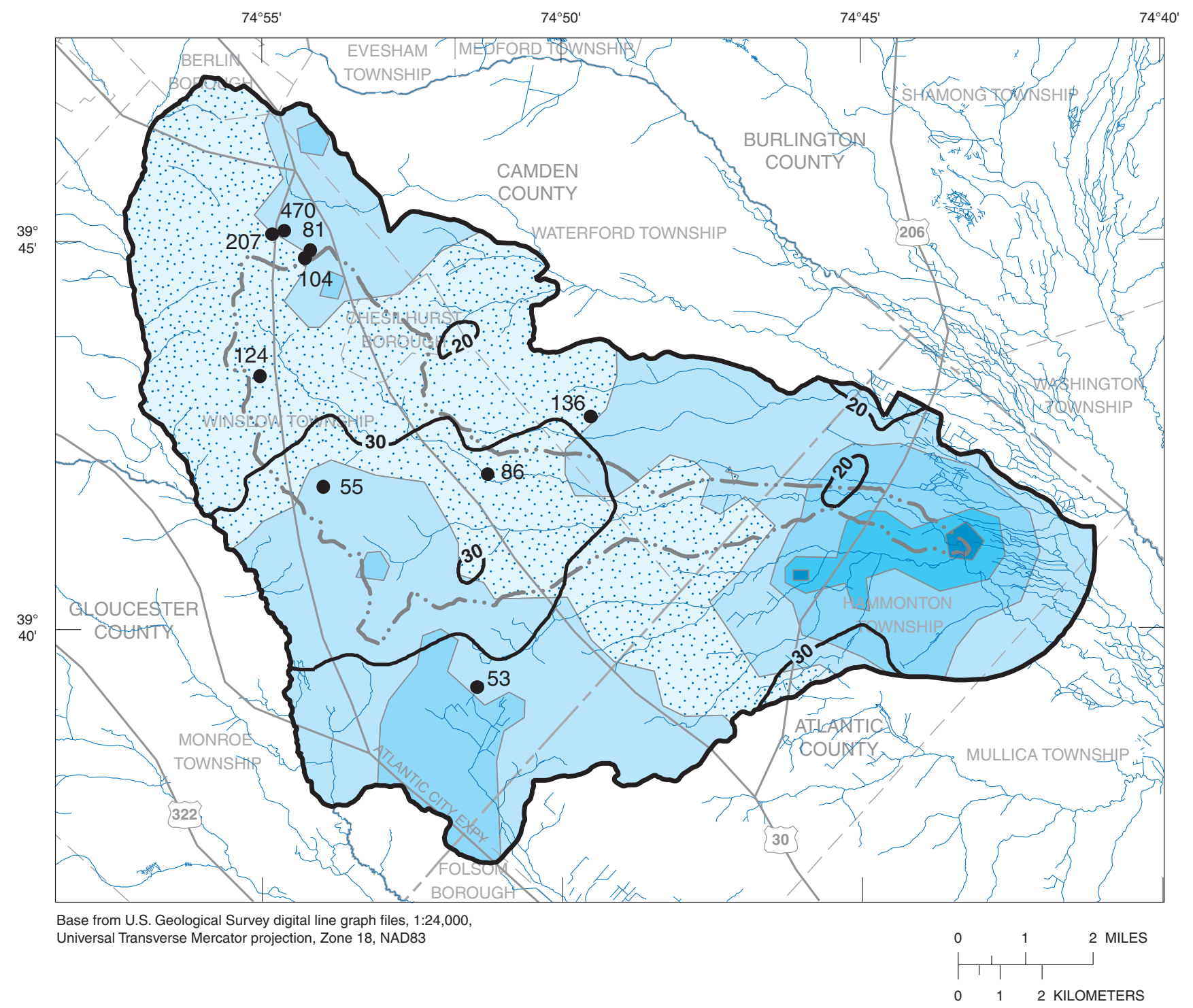

\section{EXPLANATION}

Estimated sand content in the AB C-2 leaky confining layer

Mostly sand

More sand than clay

Sand and clay

More clay than sand

Mostly clay

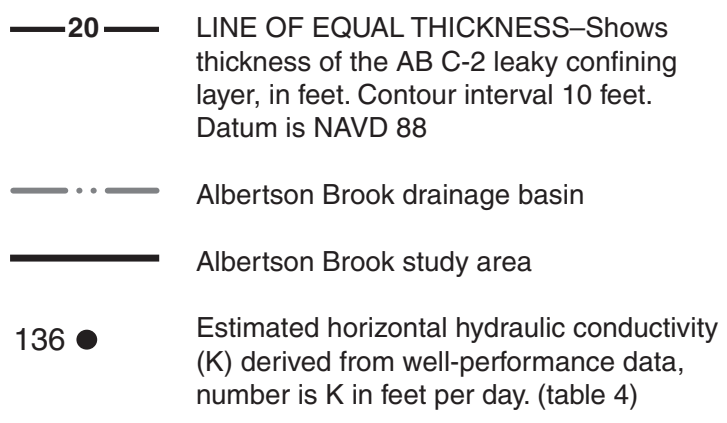

(K) derived from well-performance data, number is $\mathrm{K}$ in feet per day. (table 4)

Figure 2-11. Thickness, estimated sand content, and horizontal hydraulic conductivity of the AB C-2 leaky confining layer of the Kirkwood-Cohansey aquifer system, Albertson Brook study area and vicinity, New Jersey Pinelands. 


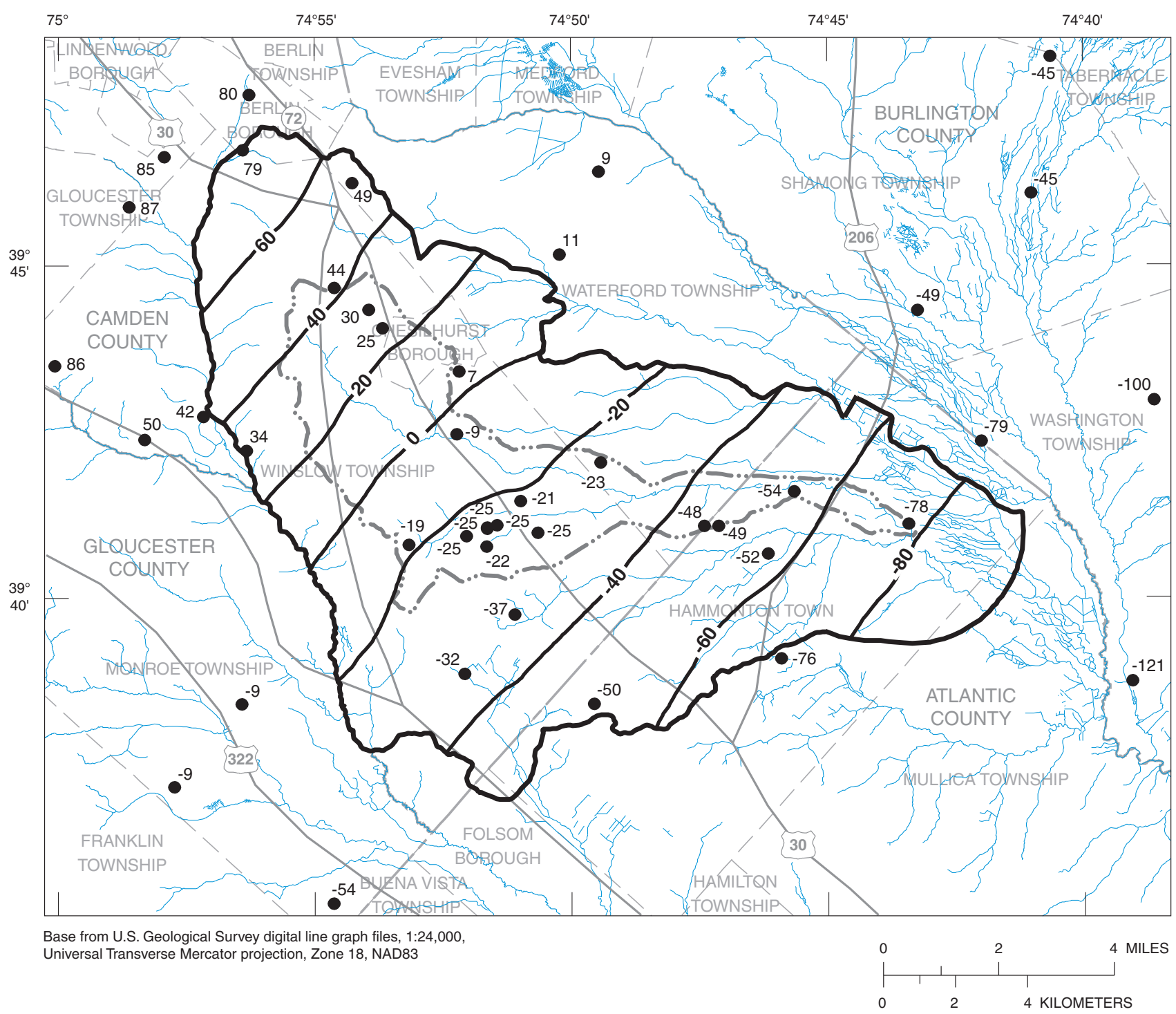

EXPLANATION

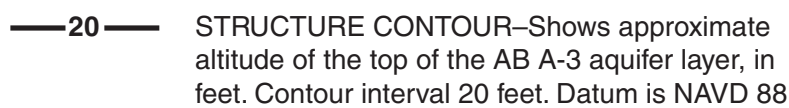

$\ldots$ Albertson Brook drainage basin

Albertson Brook study area

-37 Well or borehole. Number is altitude of the top of the layer, in feet. Datum is NAVD 88

Figure 2-12. Structure contours of the top of the AB A-3 aquifer layer of the Kirkwood-Cohansey aquifer system, Albertson Brook study area and vicinity, New Jersey Pinelands. 


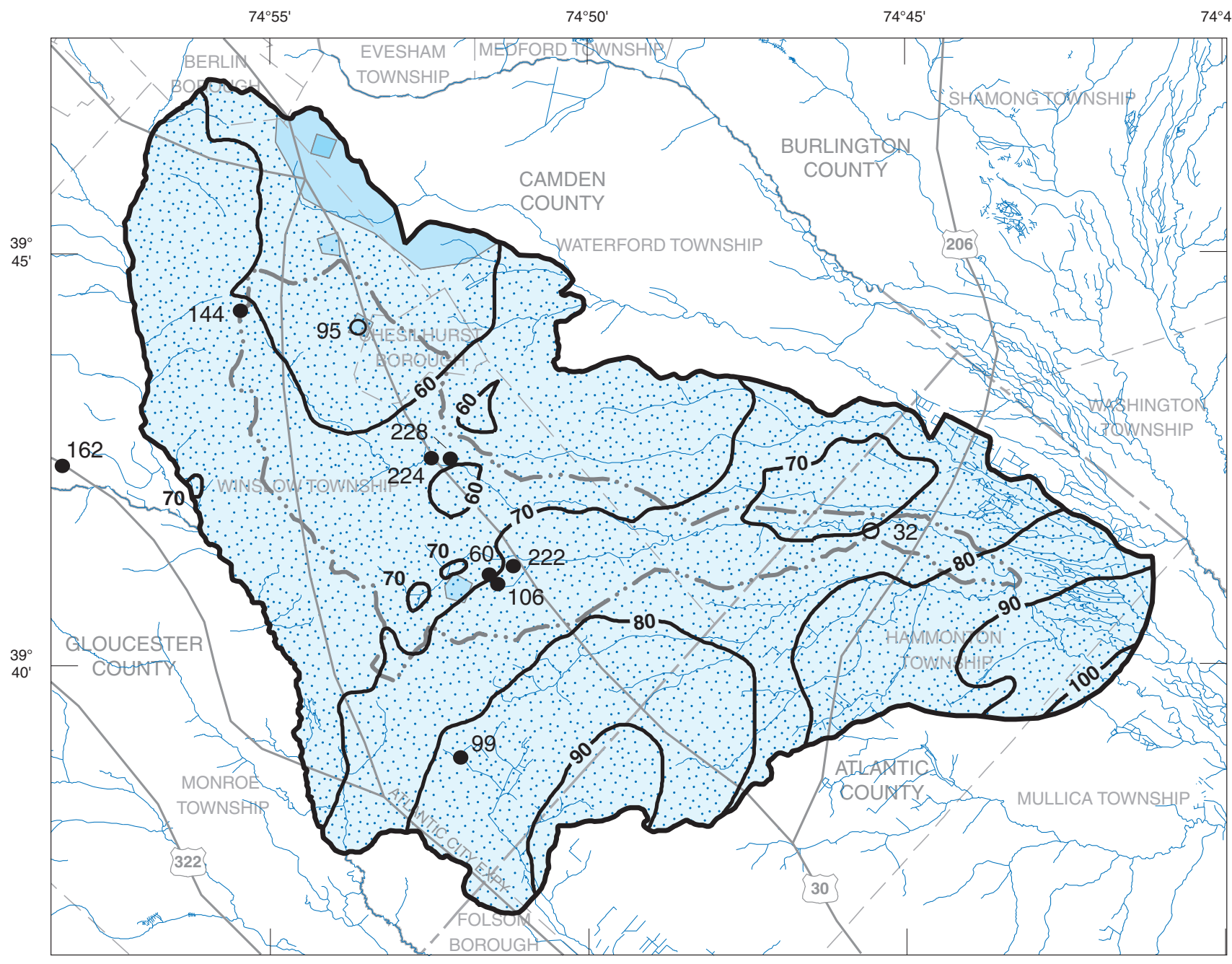

Base from U.S. Geological Survey digital line graph files, 1:24,000,

Universal Transverse Mercator projection, Zone 18, NAD83

EXPLANATION

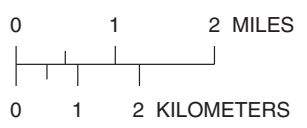

Estimated sand content in the $A B A-3$ aquifer layer

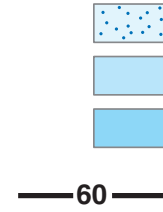

Mostly sand

More sand than clay

Sand and clay

LINE OF EQUAL THICKNESS-Shows thickness of the $A B A-3$ aquifer layer, in feet. Contour interval 10 feet. Datum is NAVD 88

Albertson Brook drainage basin
Albertson Brook study area

60

Estimated horizontal hydraulic conductivity (K) derived from well-performance data, number is $\mathrm{K}$ in feet per day. (table 4)

Estimated horizontal hydraulic conductivity

950
(K) derived from slug-test data, number is $\mathrm{K}$ in feet per day. (table 4)

Figure 2-13. Thickness, estimated sand content, and horizontal hydraulic conductivity of the AB A-3 aquifer layer of the KirkwoodCohansey aquifer system, Albertson Brook study area and vicinity, New Jersey Pinelands. 


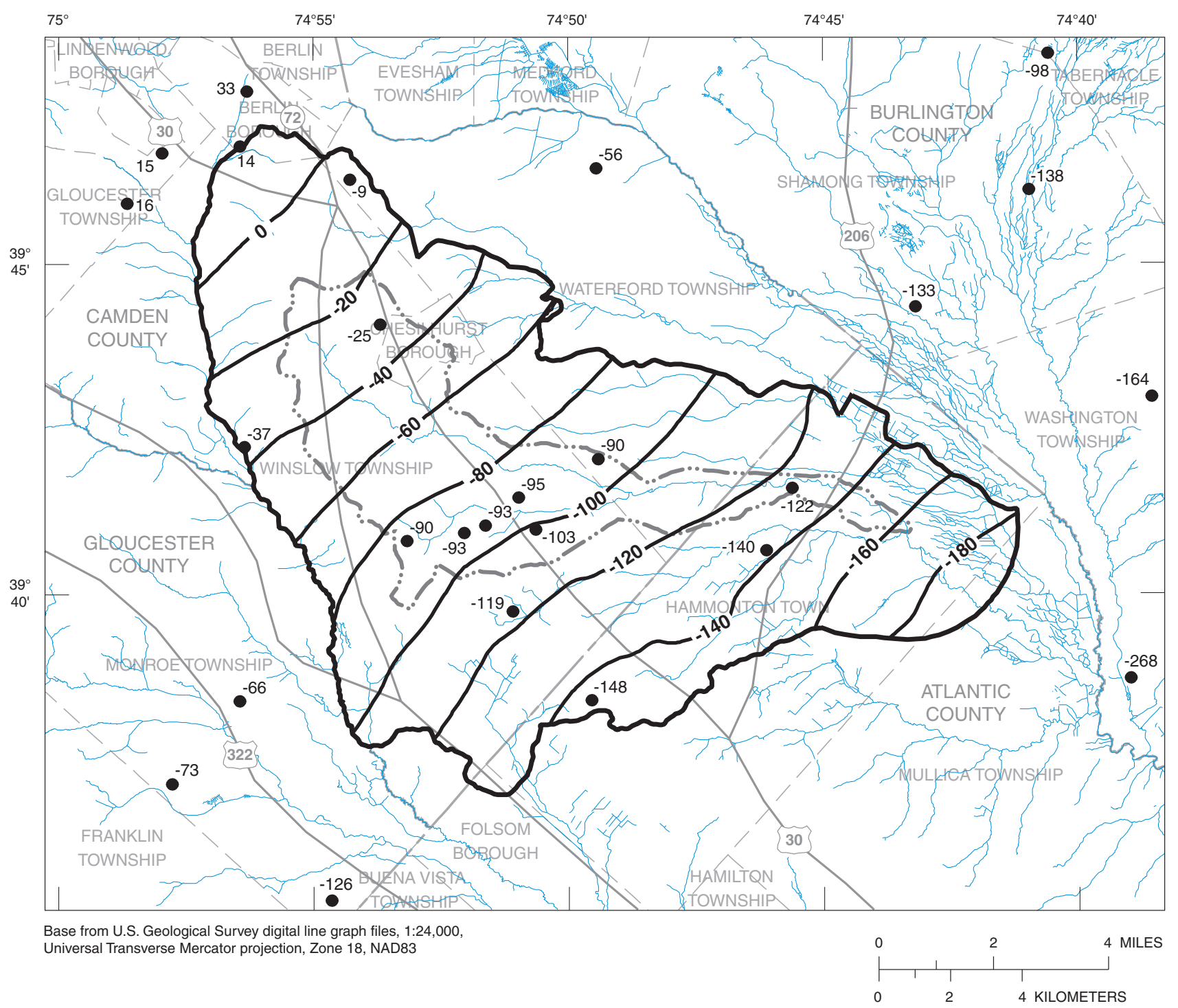

EXPLANATION

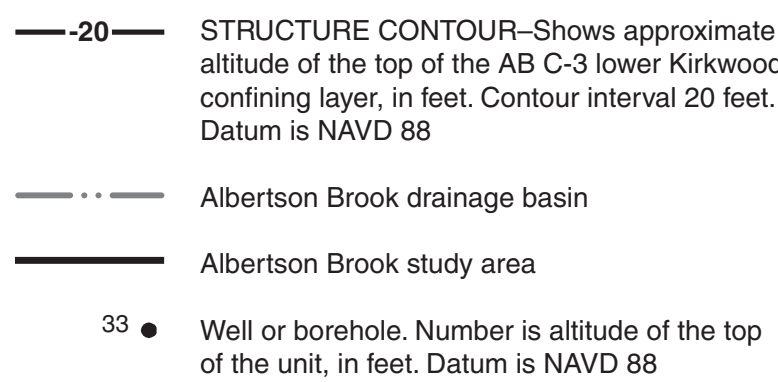

Figure 2-14. Structure contours of the top of the AB C-3 lower Kirkwood confining layer of the Kirkwood-Cohansey aquifer system, Albertson Brook study area and vicinity, New Jersey Pinelands. 



\section{Appendix 3}

Altitude, thickness, estimated sand content, and (or) horizontal hydraulic conductivity of hydrogeologic layers of the Kirkwood-Cohansey aquifer system, McDonalds Branch study area and vicinity, New Jersey Pinelands. 


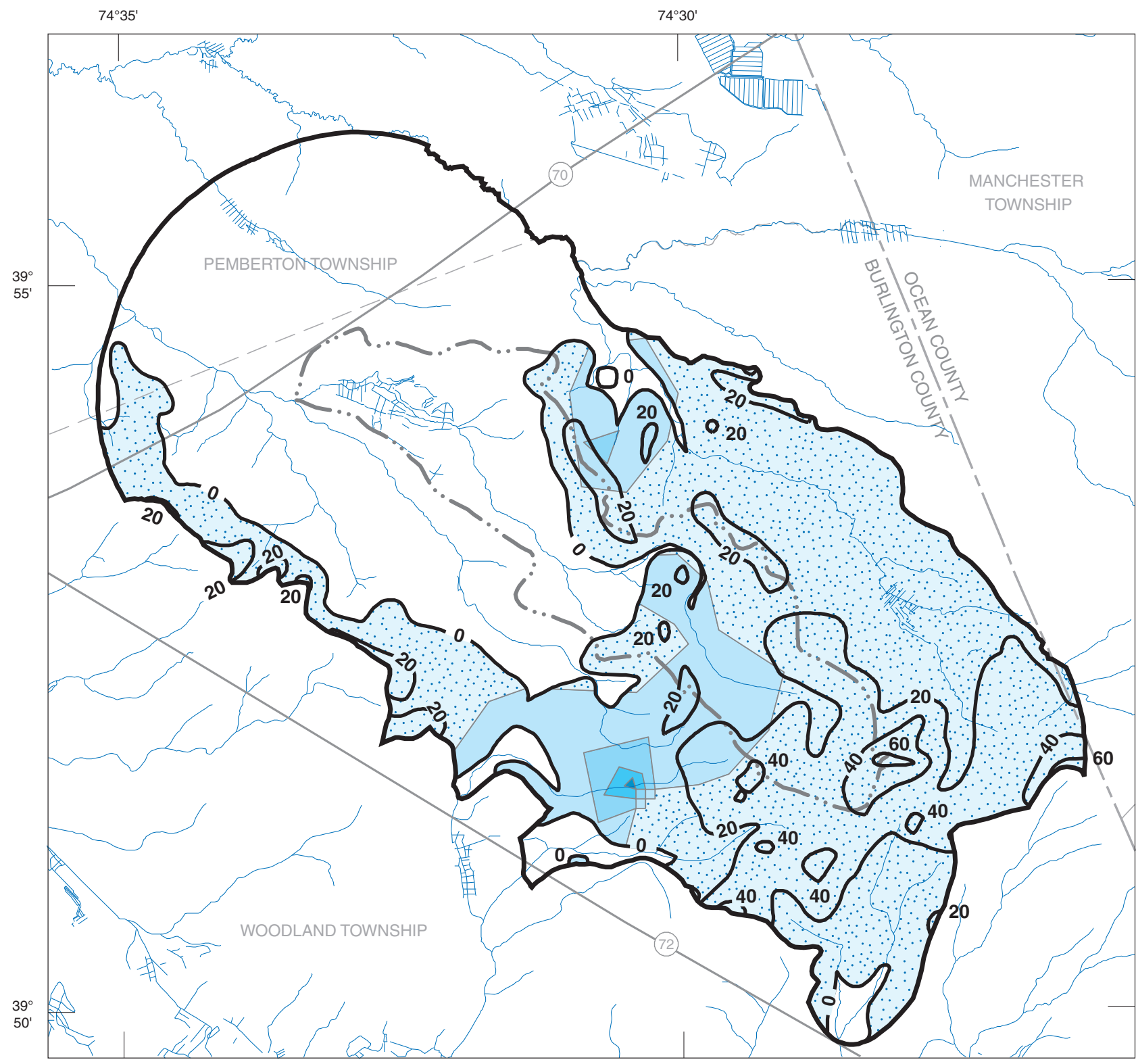

Base from U.S. Geological Survey digital line graph files, 1:24,000 Universal Transverse Mercator projection, Zone 18, NAD83

EXPLANATION

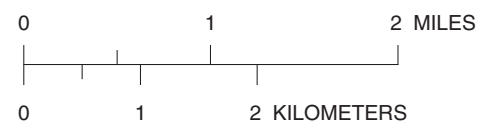

Estimated sand content in the MB A-1 aquifer layer

Mostly sand

More sand than clay

Sand and clay

More clay than sand

Mostly clay

Area beyond the extent of the MB A-1 aquifer layer

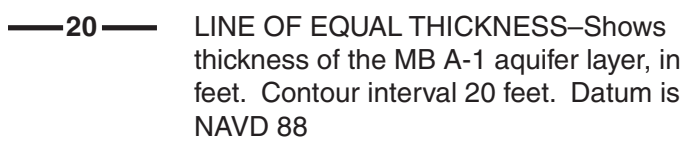

_.. McDonalds Branch drainage basin

McDonalds Branch study area

Figure 3-1. Thickness and estimated sand content of the MB A-1 aquifer layer of the Kirkwood-Cohansey aquifer system, McDonalds Branch study area and vicinity, New Jersey Pinelands. 


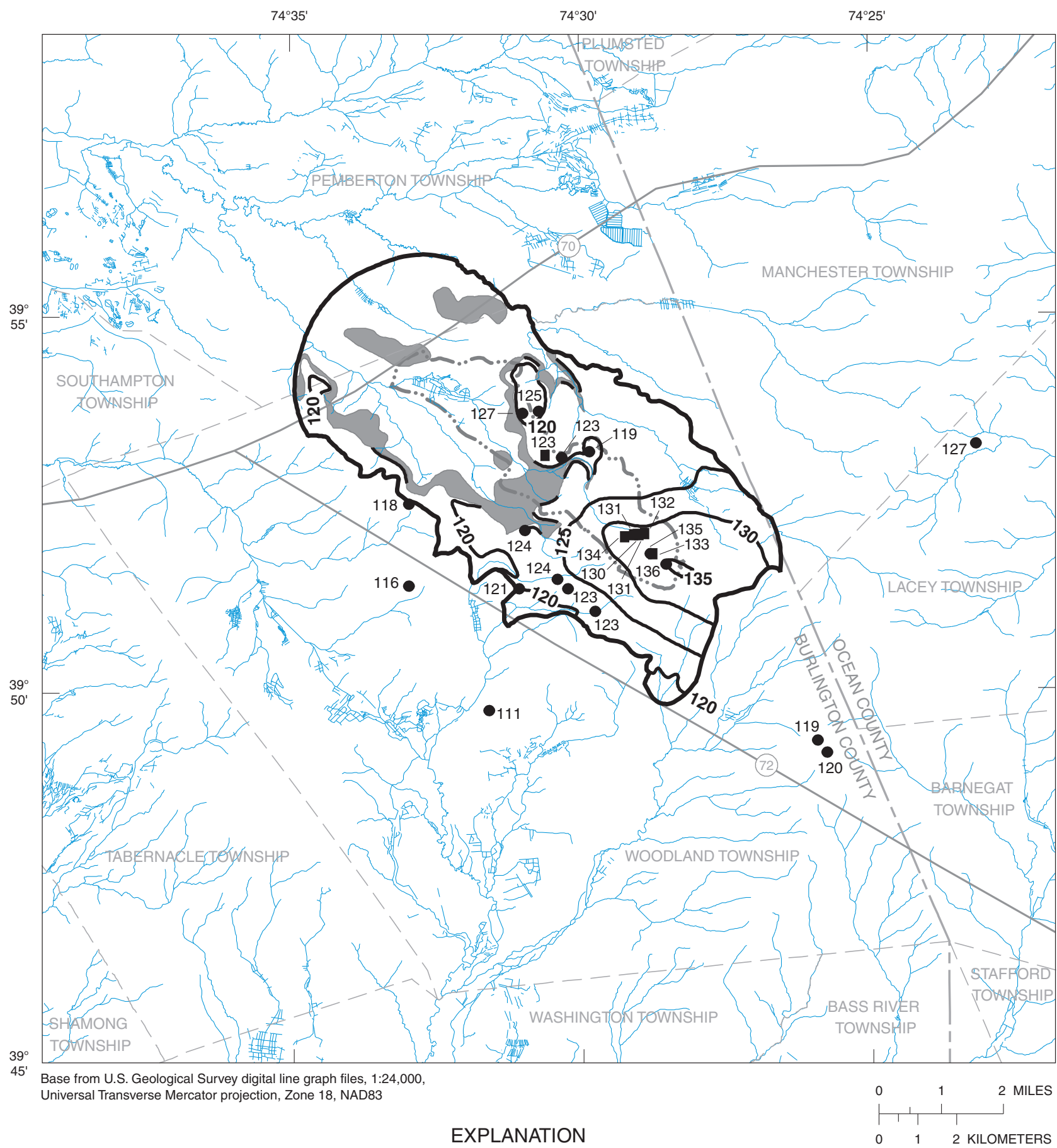

Outcrop area of the MB A-1C1 leaky confining layer of the KirkwoodCohansey aquifer system

-130 - STRUCTURE CONTOUR-Shows approximate altitude of the top of the MB A-1C1 leaky confining layer, in feet. Contour interval 5 feet. Datum is NAVD 88

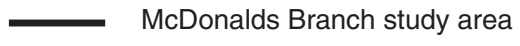

110 Well or borehole. Number is altitude of the top of the layer, in feet. Datum is NAVD 88

132 - Ground penetrating radar (GPR) survey site. Number is altitude of the top of the layer, in feet. Datum is NAVD 88

-.. McDonalds Branch drainage basin

Figure 3-2. Structure contours of the top of the MB A-1C1 leaky confining layer of the Kirkwood-Cohansey aquifer system, McDonalds Branch study area and vicinity, New Jersey Pinelands. 


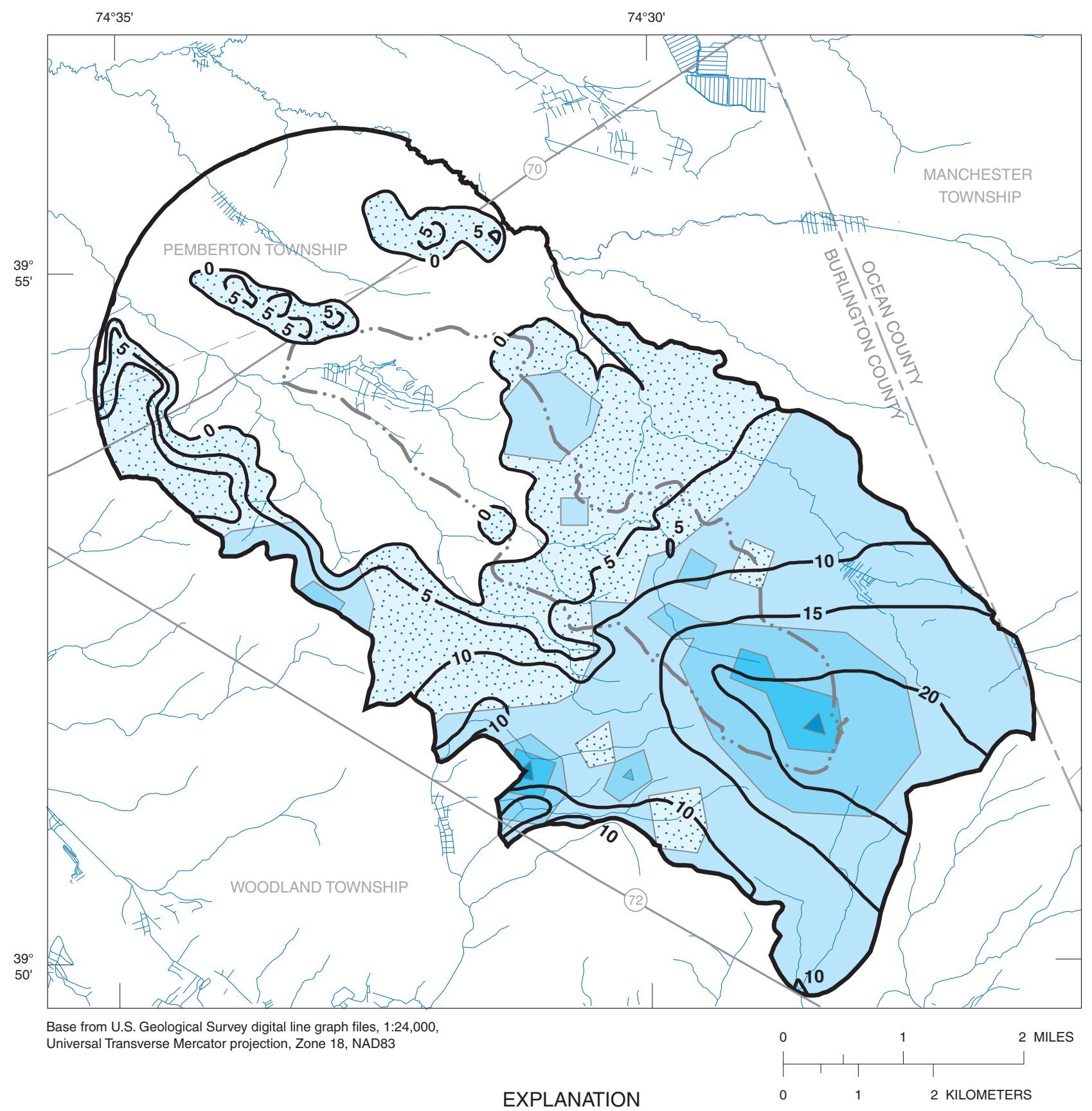

Estimated sand content in the MB A-1C1 leaky confining layer

\begin{tabular}{|c|c|}
\hline Mostly sand & LINE OF EQUAL THICKNESS-Shows \\
\hline More sand than clay & $\begin{array}{l}\text { thickness of the MB A-1C } 1 \text { leaky confining } \\
\text { laver in feet Contour interval } 5 \text { feet }\end{array}$ \\
\hline Sand and clay & Datum is NAVD 88 \\
\hline More clay than sand & McDonalds Branch drainage basin \\
\hline Mostly clay & \\
\hline $\begin{array}{l}\text { Area beyond the extent of the } \\
\text { MB A-1C1 leaky confining layer }\end{array}$ & 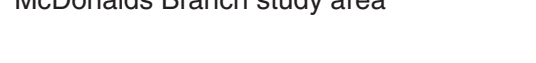 \\
\hline
\end{tabular}

Figure 3-3. Thickness and estimated sand content of the MB A-1C1 leaky confining layer of the Kirkwood-Cohansey aquifer system, McDonalds Branch study area and vicinity, New Jersey Pinelands. 


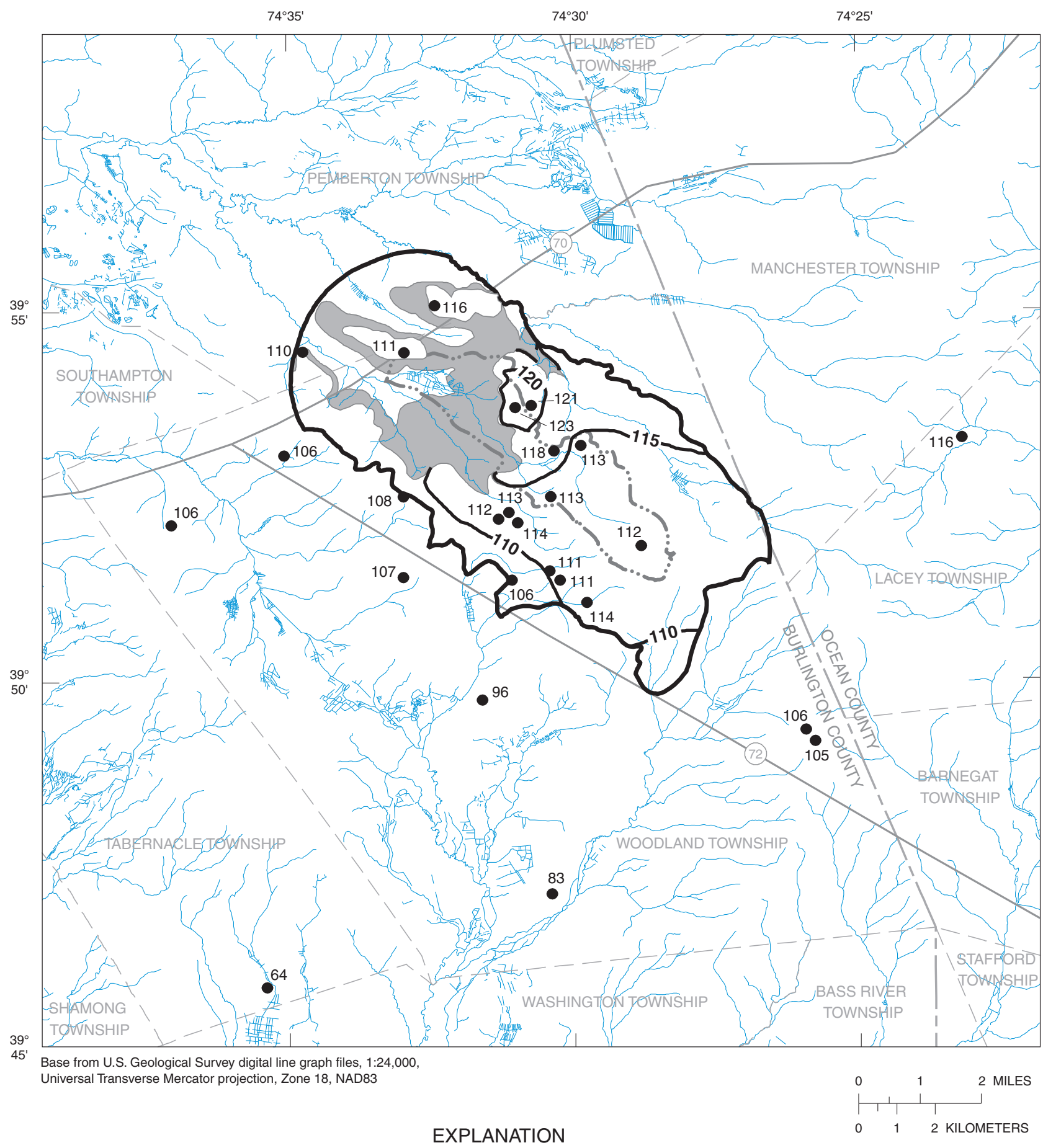

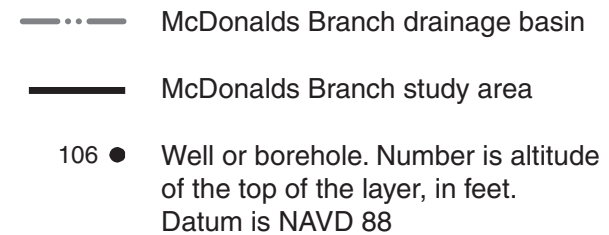

Datum is NAVD 88

Figure 3-4. Structure contours of the top of the MB A-1B aquifer layer of the Kirkwood-Cohansey aquifer system, McDonalds Branch study area and vicinity, New Jersey Pinelands. 


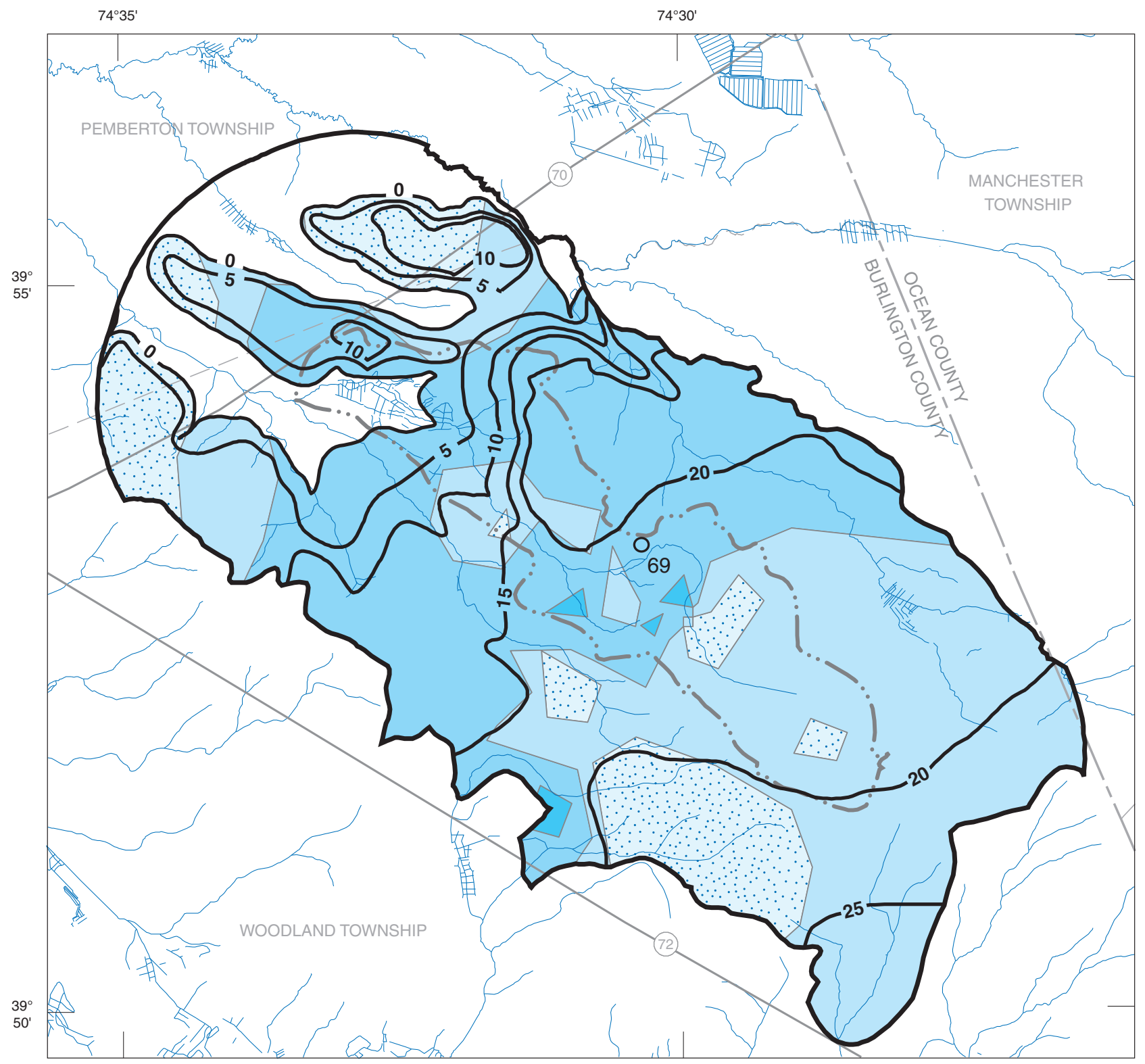

Base from U.S. Geological Survey digital line graph files, 1:24,000, Universal Transverse Mercator projection, Zone 18, NAD83

\section{EXPLANATION}

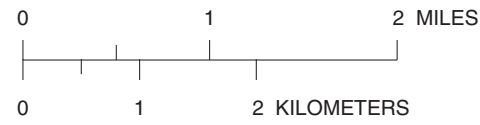

Estimated sand content in the MB A-1B aquifer layer

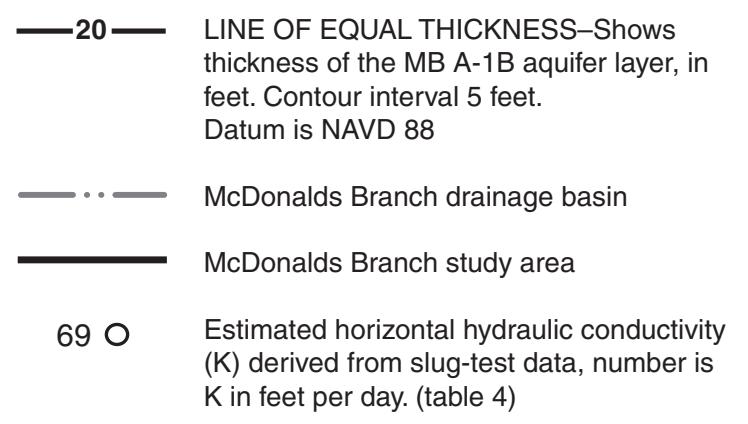

\section{Mostly sand}

More sand than clay

Sand and clay

More clay than sand

Area beyond the extent of the MB A-1B aquifer layer
(K) derived from slug-test data, number is $\mathrm{K}$ in feet per day. (table 4)

Figure 3-5. Thickness, estimated sand content, and horizontal hydraulic conductivity of the MB A-1B aquifer layer of the KirkwoodCohansey aquifer system, McDonalds Branch study area and vicinity, New Jersey Pinelands. 


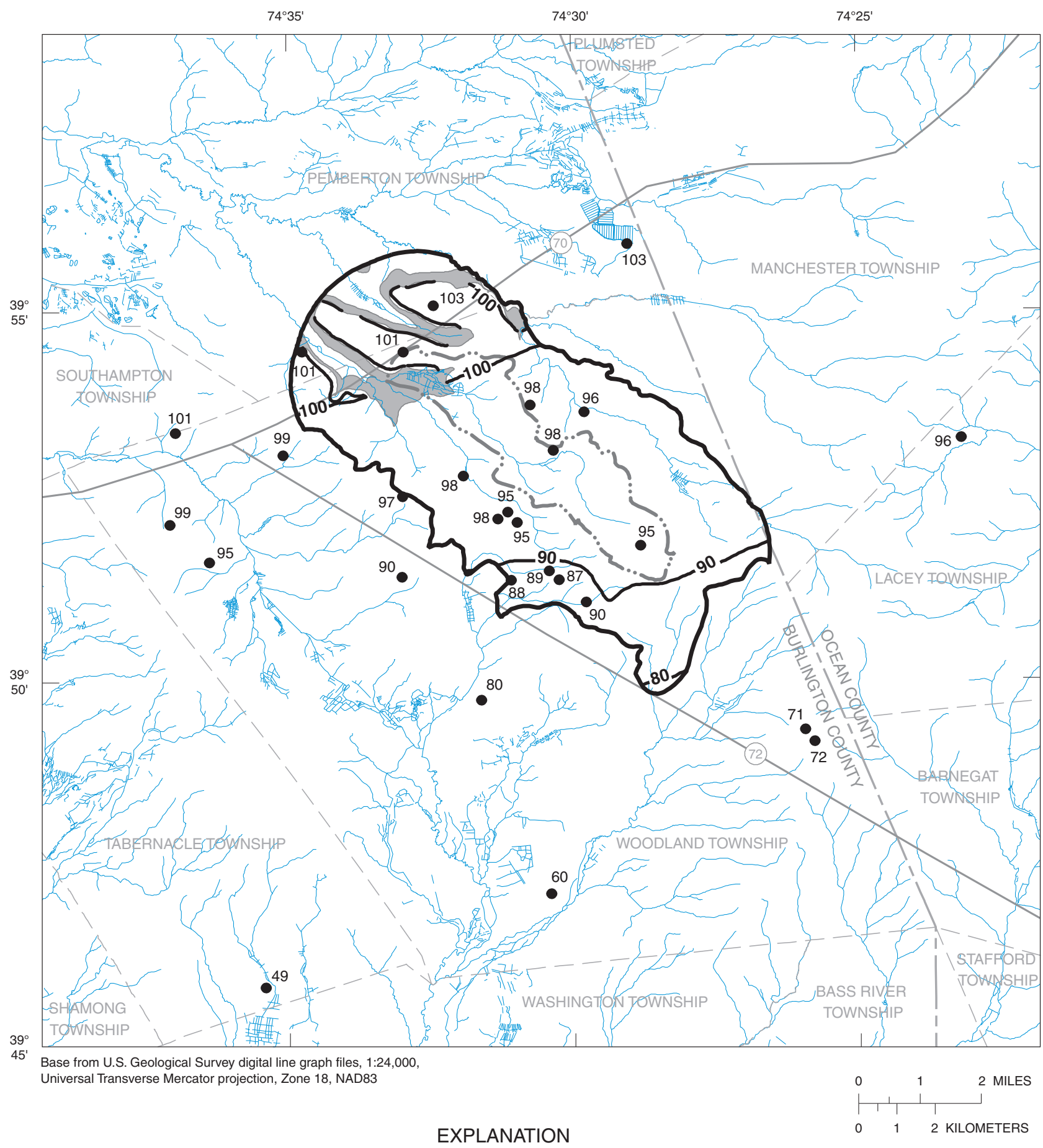

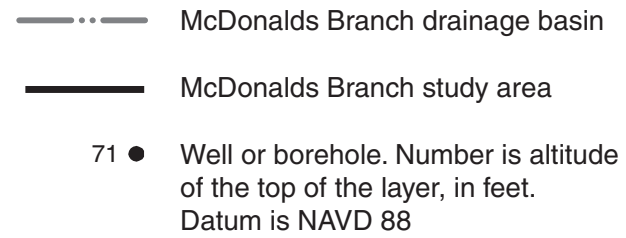

Figure 3-6. Structure contours of the top of the MB C-1 leaky confining layer of the Kirkwood-Cohansey aquifer system, McDonalds Branch study area and vicinity, New Jersey Pinelands. 


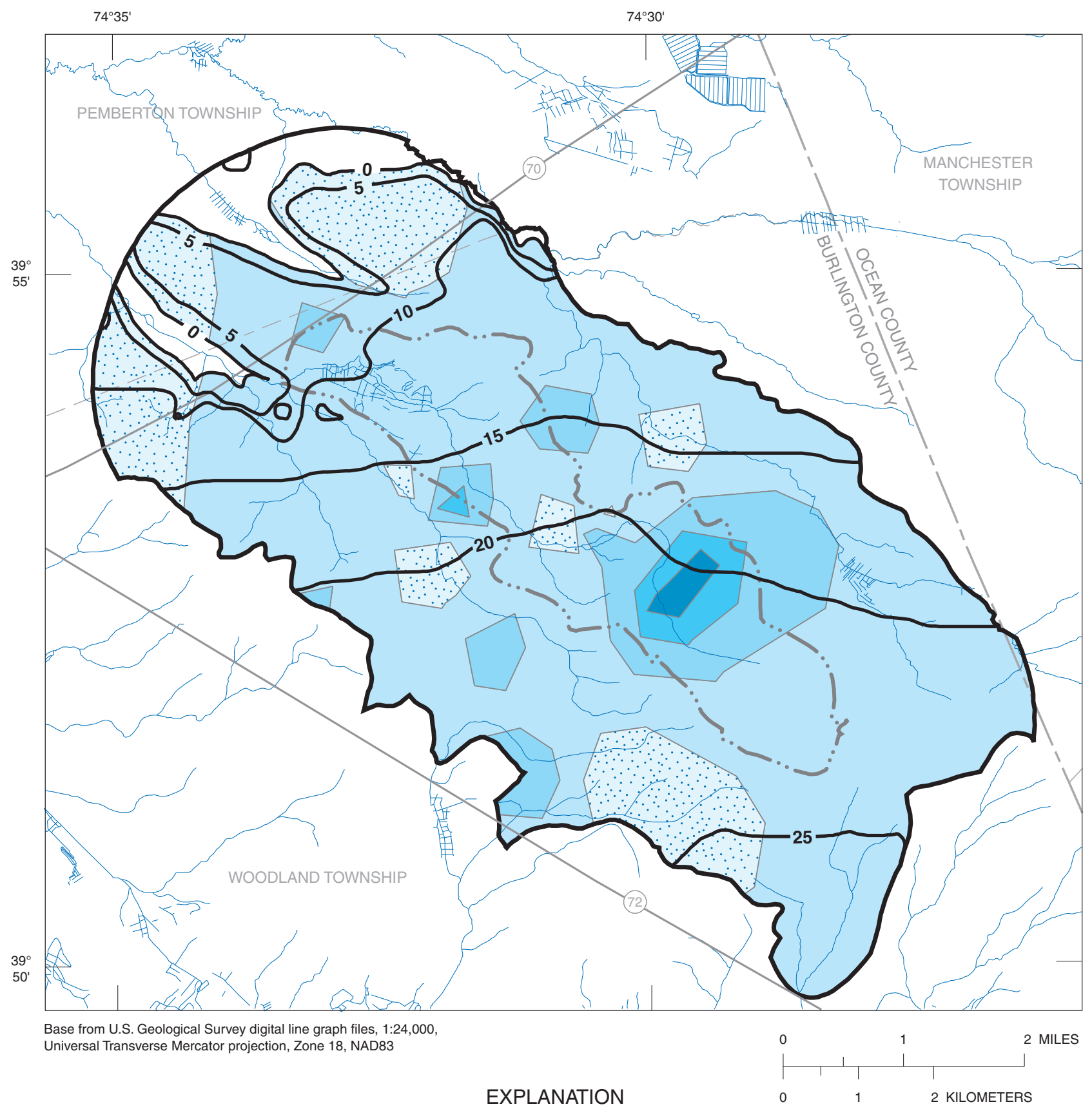

Estimated sand content in the MB C-1 leaky confining layer

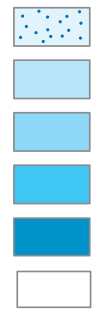

Mostly sand

More sand than clay

Sand and clay

More clay than sand

Mostly clay

Area beyond the extent of the MB C-1 leaky confining layer

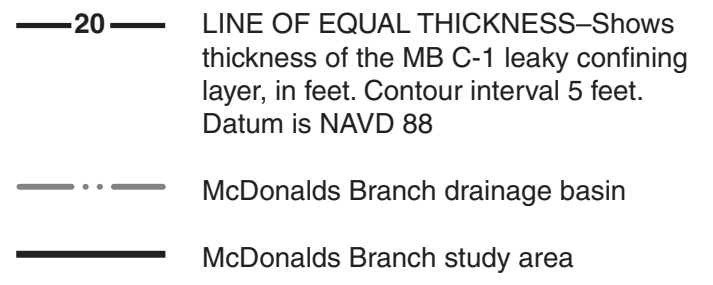

Figure 3-7. Thickness and estimated sand content of the MB C-1 leaky confining layer of the Kirkwood-Cohansey aquifer system, McDonalds Branch study area and vicinity, New Jersey Pinelands. 


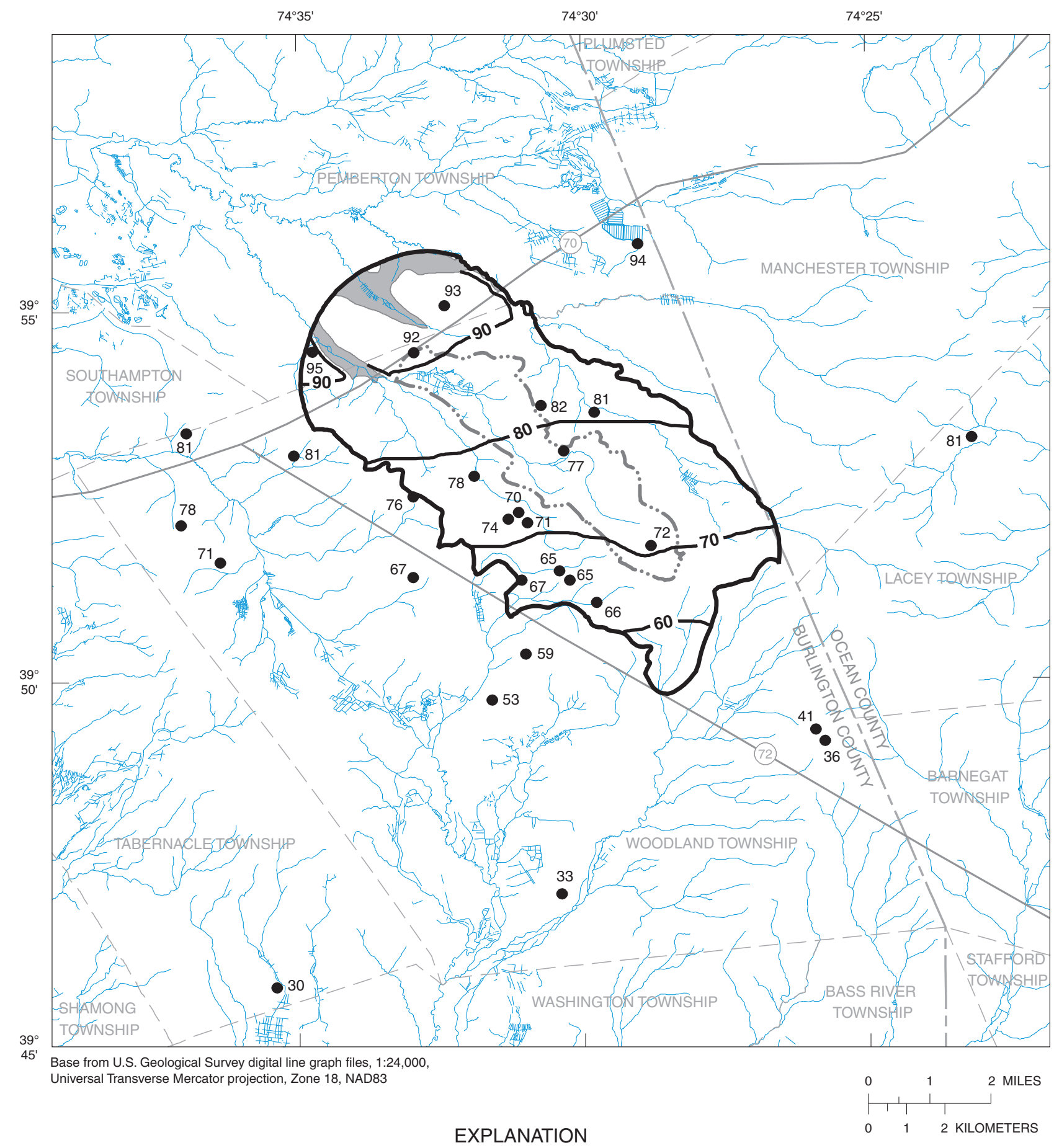

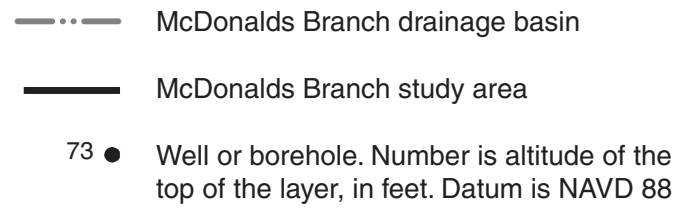

Figure 3-8. Structure contours of the top of the MB A-2 aquifer layer of the Kirkwood-Cohansey aquifer system, McDonalds Branch study area and vicinity, New Jersey Pinelands. 


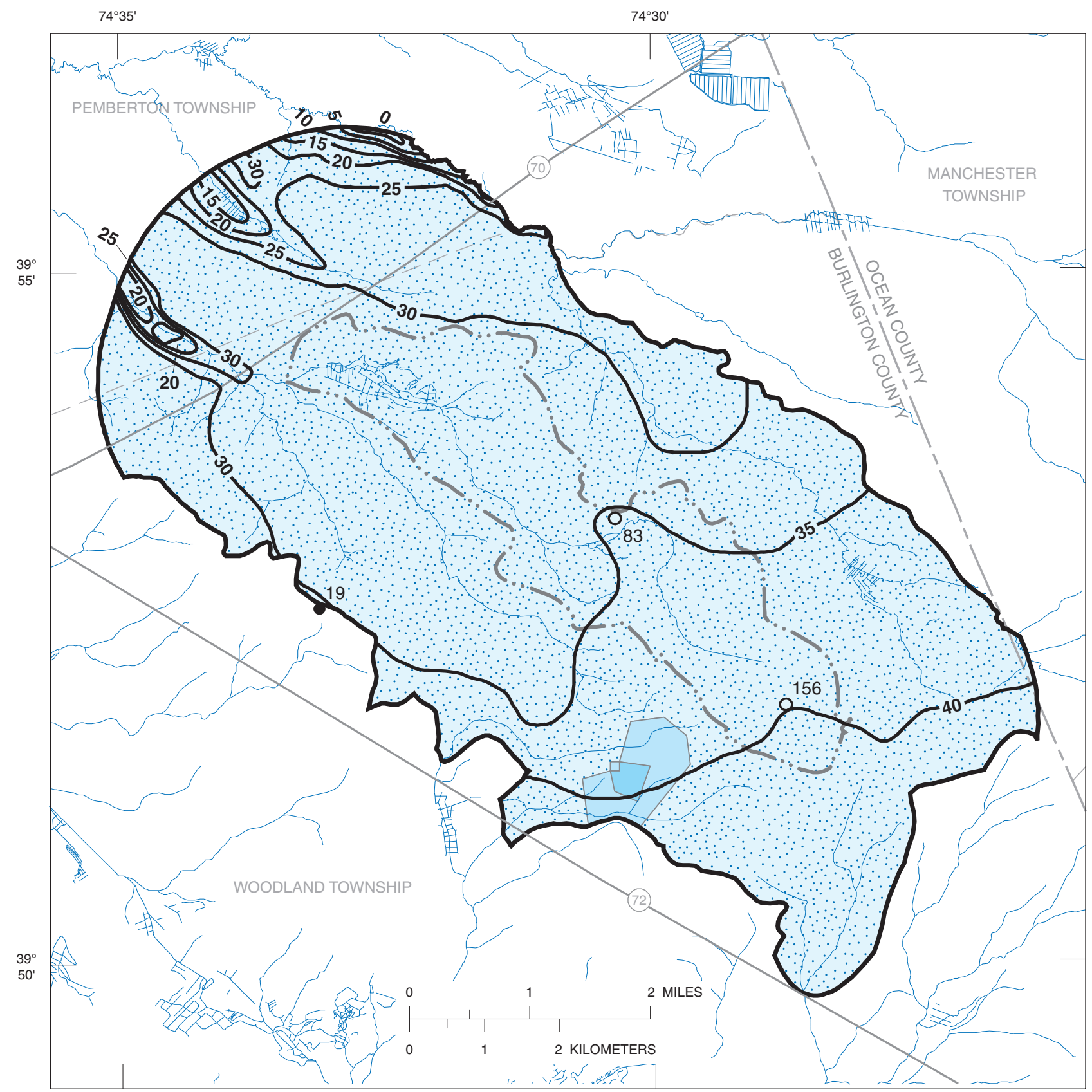

Base from U.S. Geological Survey digital line graph files, 1:24,000, Universal Transverse Mercator projection, Zone 18, NAD83

\section{EXPLANATION}

Estimated sand content in the MB A-2 aquifer layer

Mostly sand

More sand than clay

Sand and clay

McDonalds Branch drainage basin
-20 LINE OF EQUAL THICKNESS-Shows thickness of the MB A-2 aquifer layer, in feet. Contour interval 5 feet. Datum is NAVD 88

McDonalds Branch study area

830 Estimated horizontal hydraulic conductivity $(\mathrm{K})$ derived from slug-test data, number is $\mathrm{K}$ in feet per day. (table 4)

19 Estimated horizontal hydraulic conductivity (K) derived from well-performance data, number is $\mathrm{K}$ in feet per day. (table 4)

Figure 3-9. Thickness, estimated sand content, and horizontal hydraulic conductivity of the MB A-2 aquifer layer of the KirkwoodCohansey aquifer system, McDonalds Branch study area and vicinity, New Jersey Pinelands. 


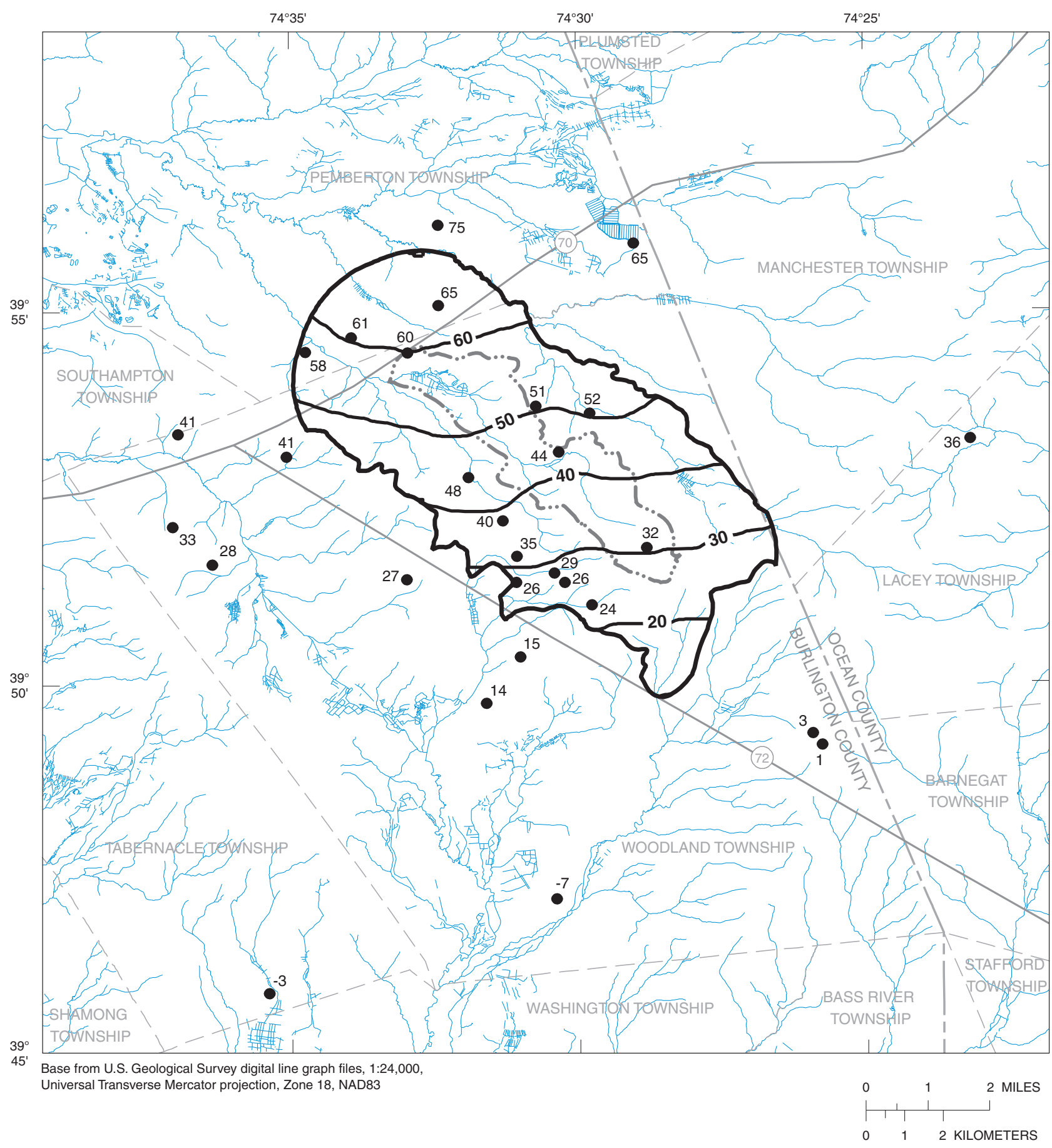

EXPLANATION

-60- STRUCTURE CONTOUR-Shows approximate altitude of the top of the MB C-2 leaky confining layer, in feet. Contour interval 10 feet. Datum is NAVD 88

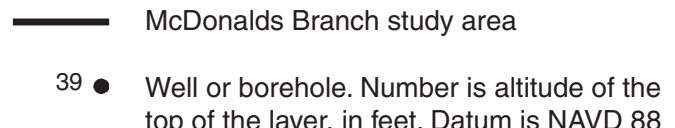
top of the layer, in feet. Datum is NAVD 88

—.. McDonalds Branch drainage basin

Figure 3-10. Structure contours of the top of the MB C-2 leaky confining layer of the Kirkwood-Cohansey aquifer system, McDonalds Branch study area and vicinity, New Jersey Pinelands. 


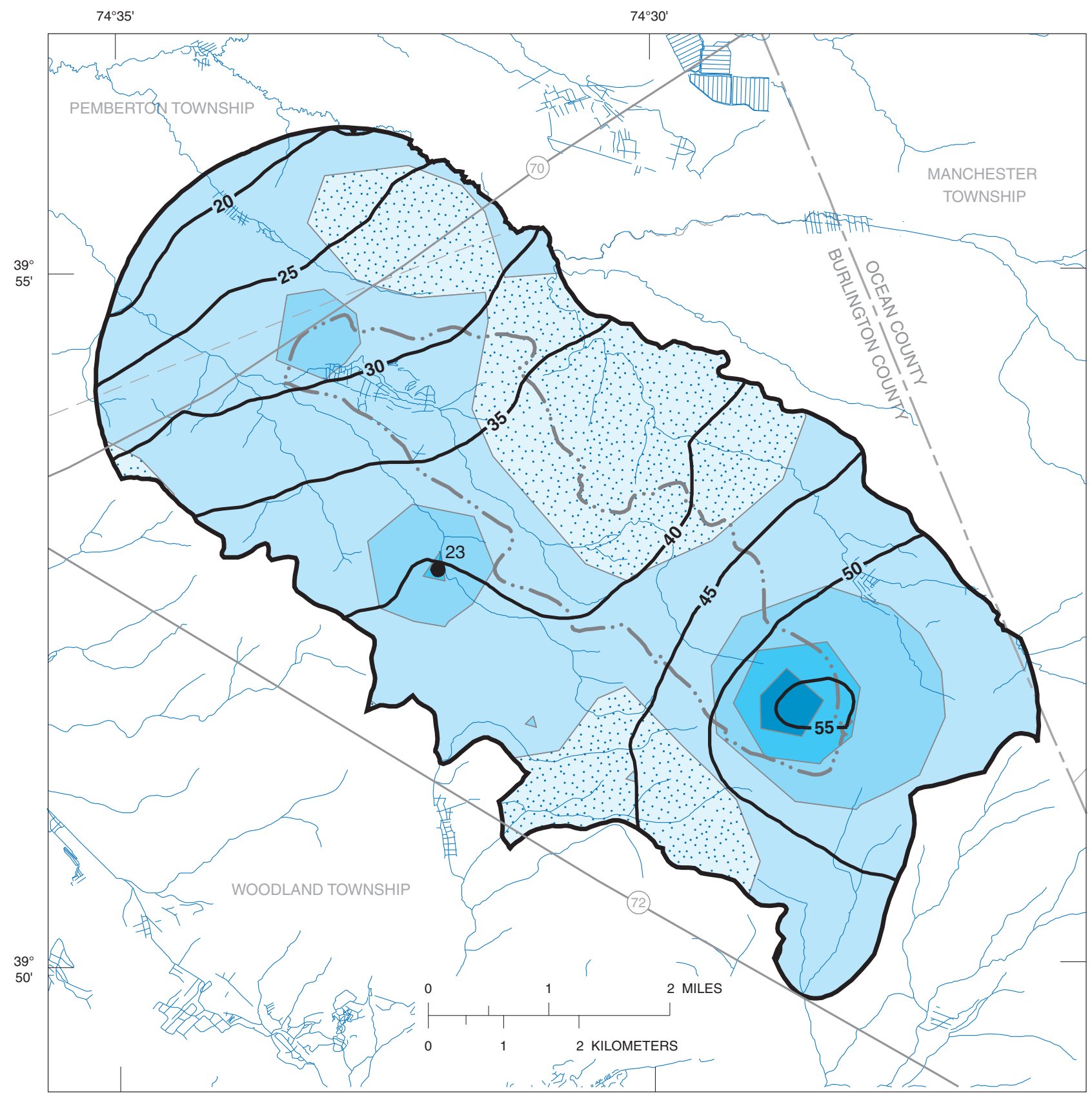

Base from U.S. Geological Survey digital line graph files, 1:24,000, Universal Transverse Mercator projection, Zone 18, NAD83

\section{EXPLANATION}

Estimated sand content in the MB C-2 leaky confining layer

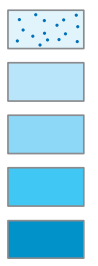

\section{Mostly sand}

More sand than clay

Sand and clay

More clay than sand

Mostly clay

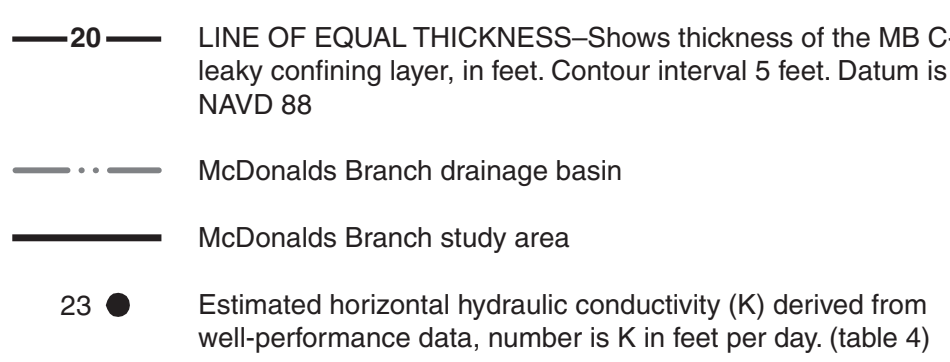

Figure 3-11. Thickness, estimated sand content, and horizontal hydraulic conductivity of the MB C-2 leaky confining layer of the Kirkwood-Cohansey aquifer system, McDonalds Branch study area and vicinity, New Jersey Pinelands. 


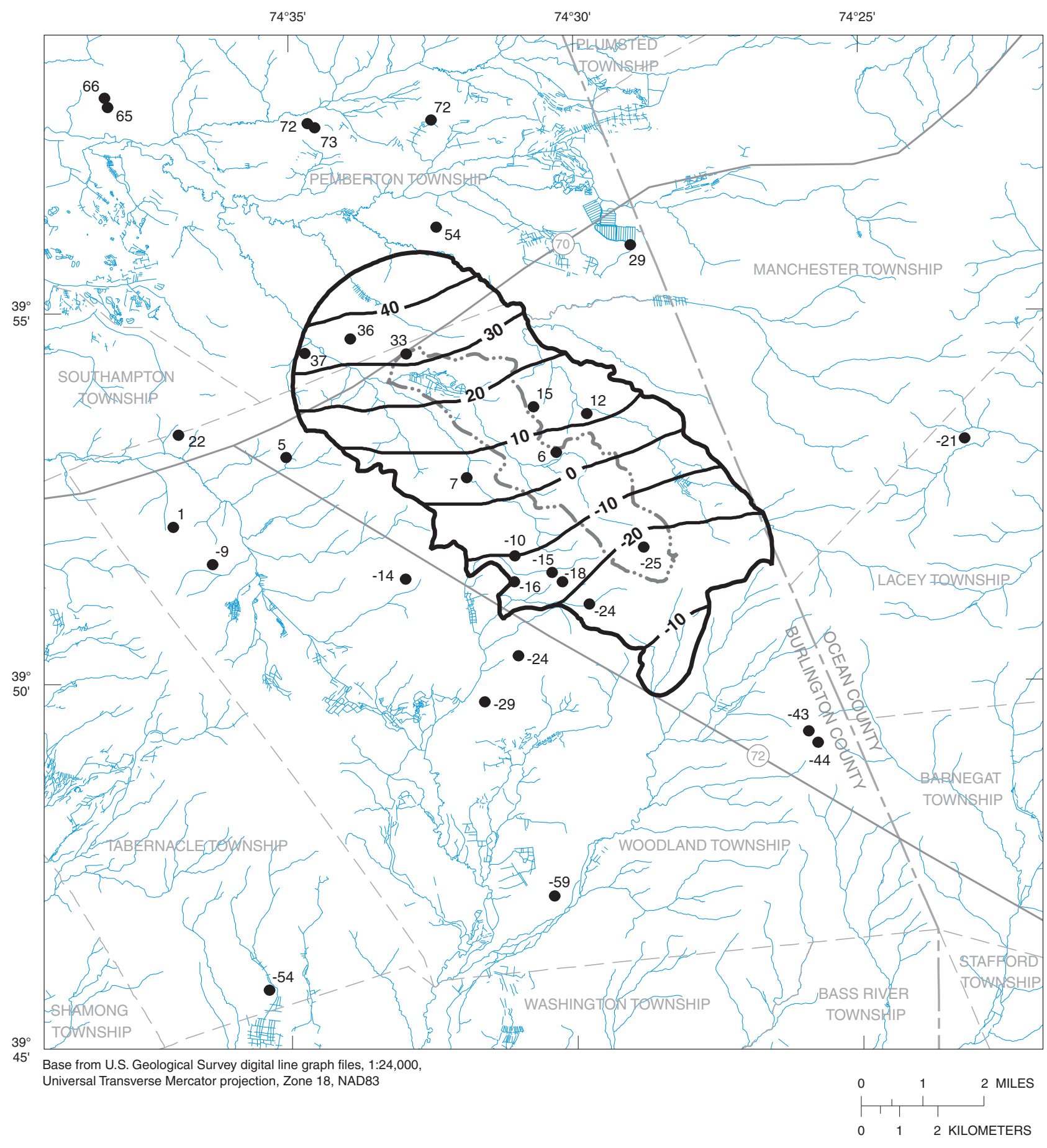

EXPLANATION

-20-STRUCTURE CONTOUR-Shows approximate altitude of the top of the MB A-3 aquifer layer, in feet. Contour interval 10 feet. Datum is NAVD 88

- McDonalds Branch drainage basin
McDonalds Branch study area

7 Well or borehole. Number is altitude of the top of the layer, in feet. Datum is NAVD 88

Figure 3-12. Structure contours of the top of the MB A-3 aquifer layer of the Kirkwood-Cohansey aquifer system, McDonalds Branch study area and vicinity, New Jersey Pinelands. 


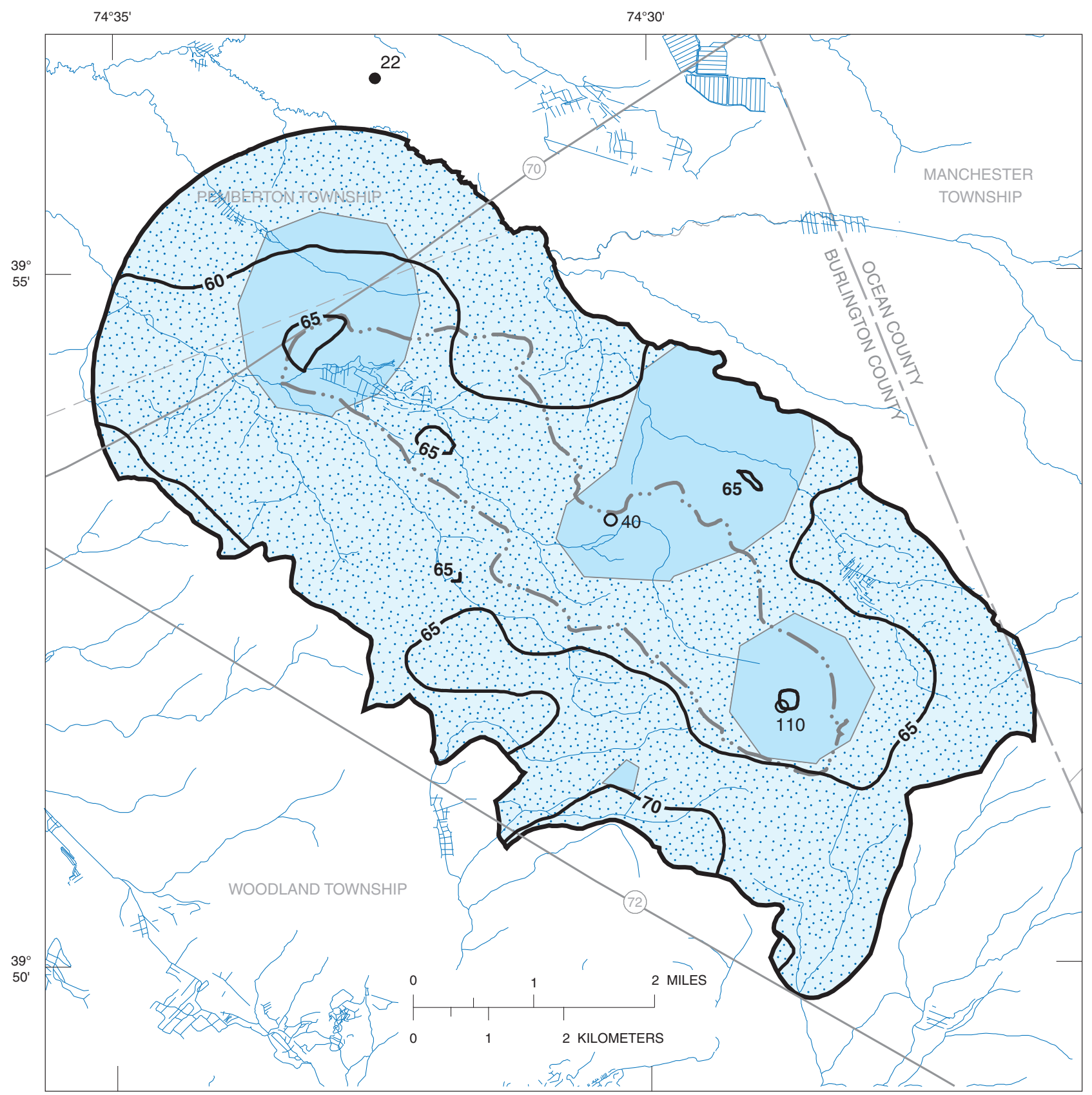

Base from U.S. Geological Survey digital line graph files, 1:24,000, Universal Transverse Mercator projection, Zone 18, NAD83

\section{EXPLANATION}

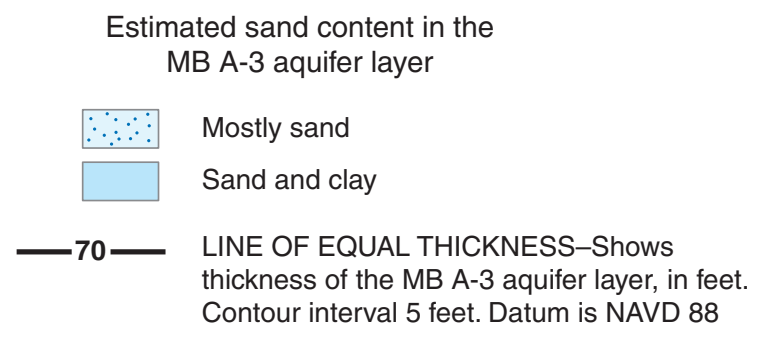

McDonalds Branch drainage basin

McDonalds Branch study area

$400 \quad$ Estimated horizontal hydraulic conductivity (K) derived from slug-test data, number is $\mathrm{K}$ in feet per day. (table 4)

22

Estimated horizontal hydraulic conductivity (K) derived from well-performance data, number is $\mathrm{K}$ in feet per day. (table 4 )

Figure 3-13. Thickness, estimated sand content, and horizontal hydraulic conductivity of the MB A-3 aquifer layer of the KirkwoodCohansey aquifer system, McDonalds Branch study area and vicinity, New Jersey Pinelands. 


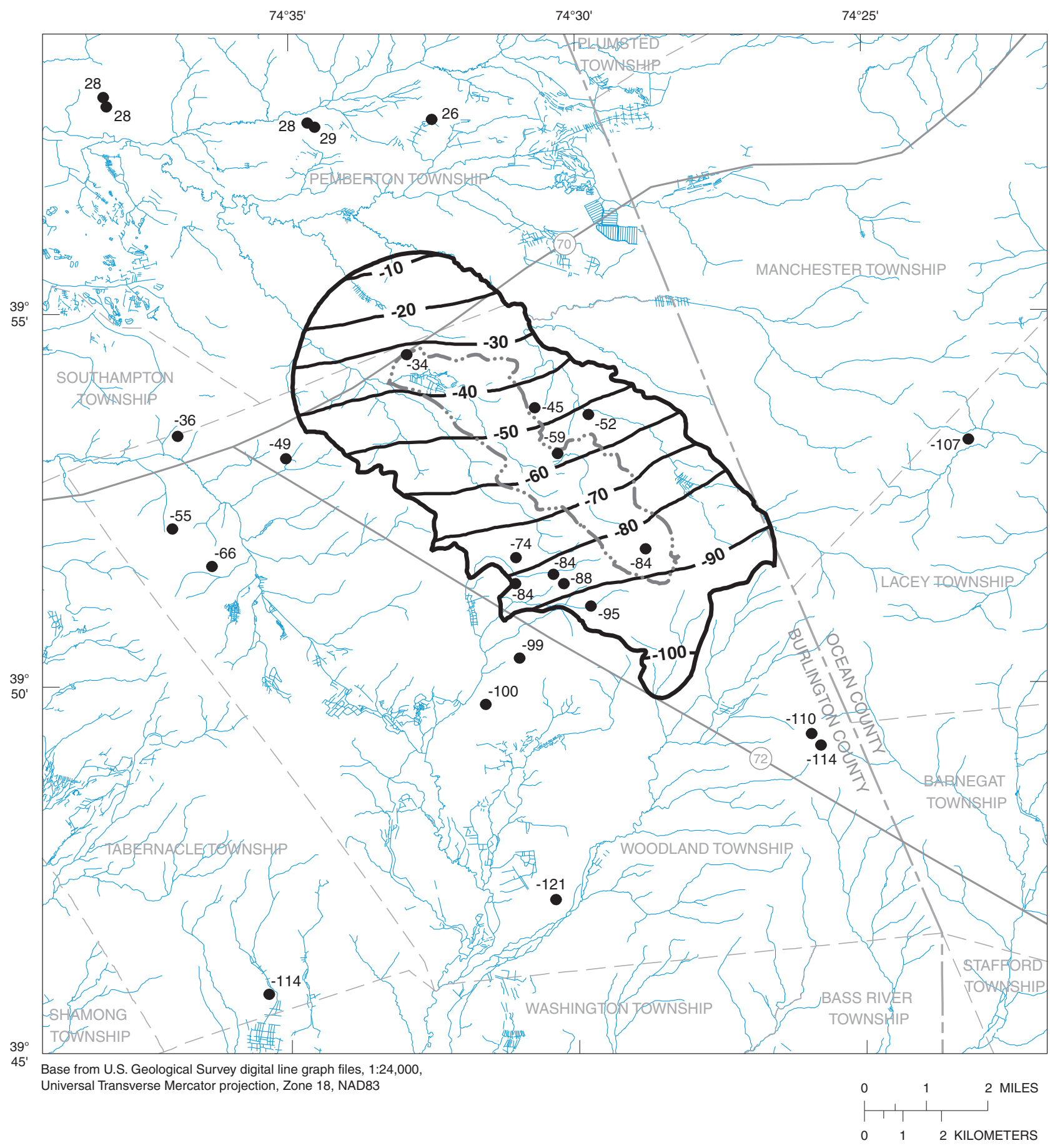

EXPLANATION

--20- STRUCTURE CONTOUR-Shows approximate altitude of the top of the MB C-3 Lower Kirkwood confining layer, in feet. Contour interval 10 feet. Datum is NAVD 88
McDonalds Branch study area

-66 Well or borehole. Number is altitude of the top of the layer, in feet. Datum is NAVD 88

- McDonalds Branch drainage basin

Figure 3-14. Structure contours of the top of the MB C-3 Lower Kirkwood confining layer of the Kirkwood-Cohansey aquifer system, McDonalds Branch study area and vicinity, New Jersey Pinelands. 



\section{Appendix 4}

Altitude, thickness, estimated sand content, and (or) horizontal hydraulic conductivity of hydrogeologic layers of the Kirkwood-Cohansey aquifer system, Morses Mill Stream study area and vicinity, New Jersey Pinelands. 


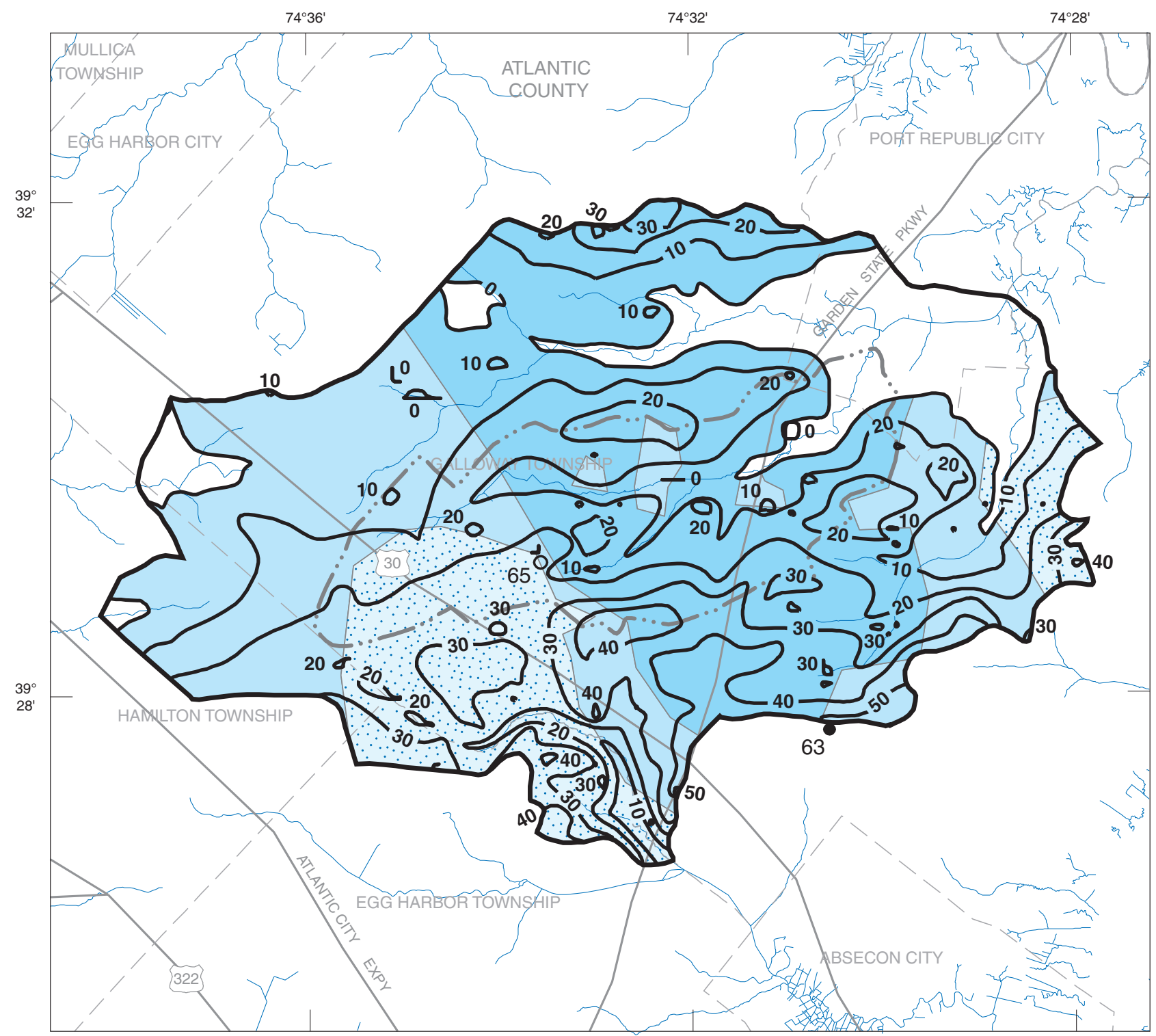

Base from U.S. Geological Survey digital line graph files, 1:24,000,

Universal Transverse Mercator projection, Zone 18, NAD83

\section{EXPLANATION}

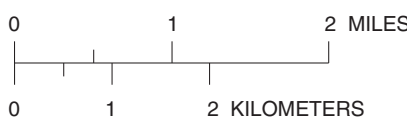

Estimated sand content in the MM A-1 aquifer layer

Mostly sand

More sand than clay

Sand and clay

Area beyond the extent of the MM A-1 aquifer layer

Morses Mill Stream drainage basin

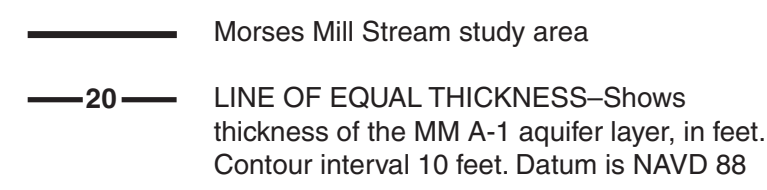

650

Estimated horizontal hydraulic conductivity (K) derived from slug-test data, number is $\mathrm{K}$ in feet per day. (table 4)

63
Estimated horizontal hydraulic conductivity (K) derived from well-performance data, number is $\mathrm{K}$ in feet per day. (table 4 )

Figure 4-1. Thickness, estimated sand content, and horizontal hydraulic conductivity of the MM A-1 aquifer layer of the KirkwoodCohansey aquifer system, Morses Mill Stream study area and vicinity, New Jersey Pinelands. 


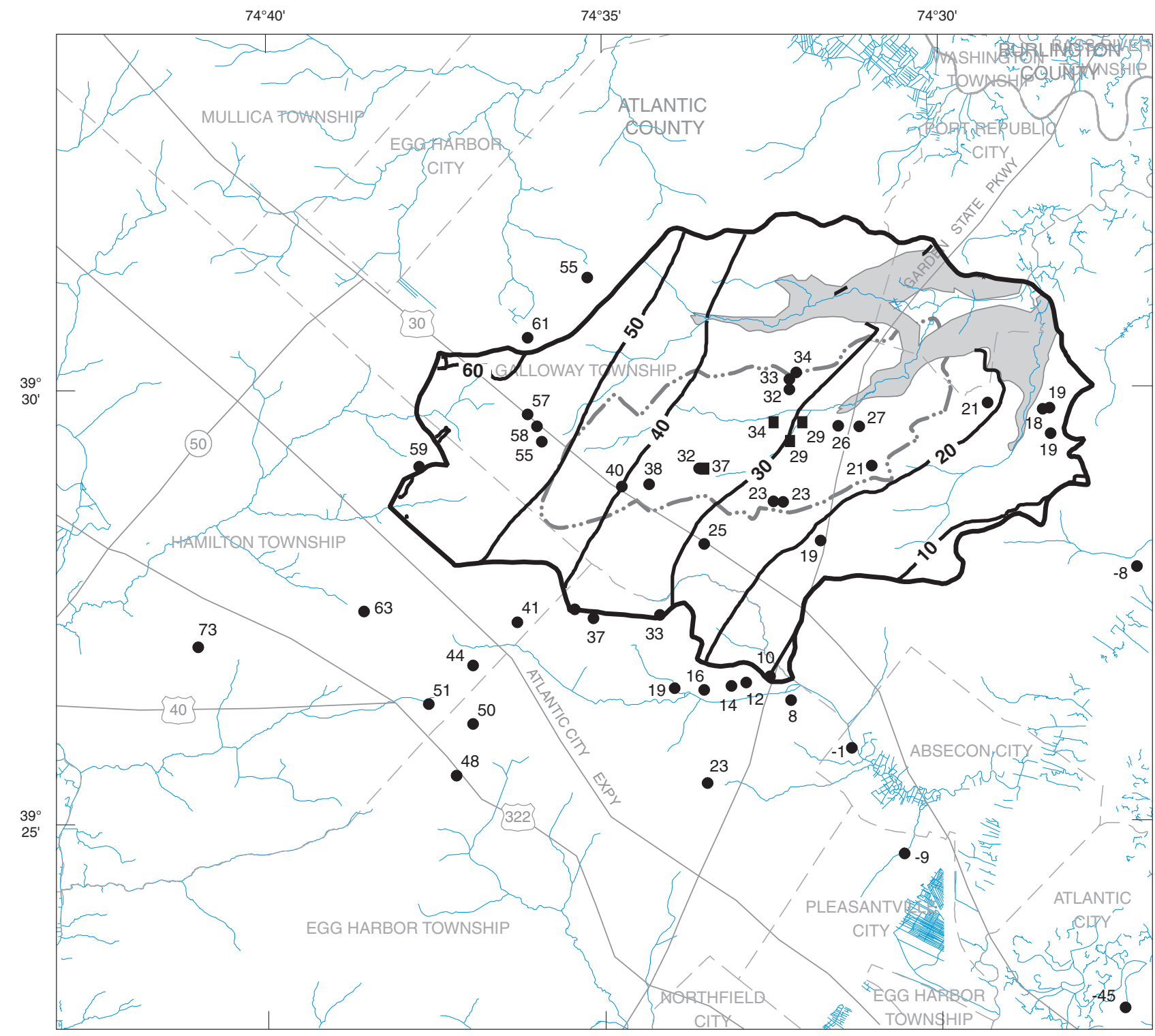

Base from U.S. Geological Survey digital line graph files, 1:24,000, Universal Transverse Mercator projection, Zone 18, NAD83

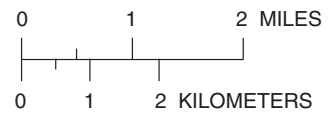

\section{EXPLANATION}

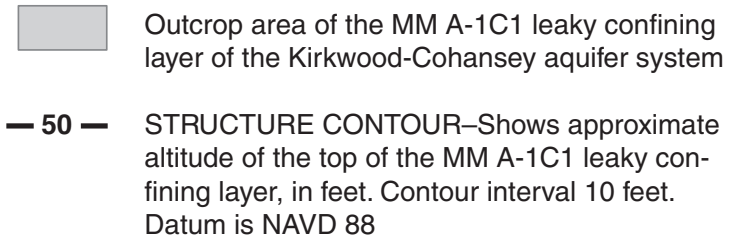

Morses Mill Stream drainage basin

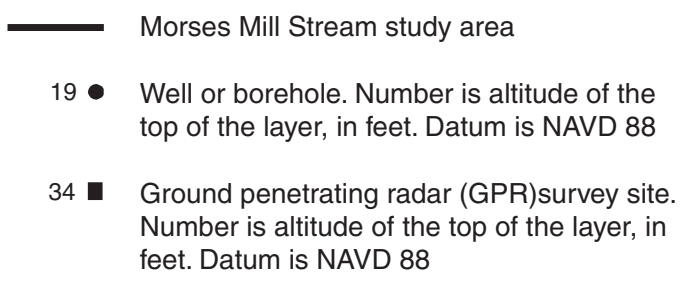
Number is altitude of the top of the layer, in is NAVD 88

Figure 4-2. Structure contours of the top of the MM A-1C1 leaky confining layer of the Kirkwood-Cohansey aquifer system, Morses Mill Stream study area and vicinity, New Jersey Pinelands. 


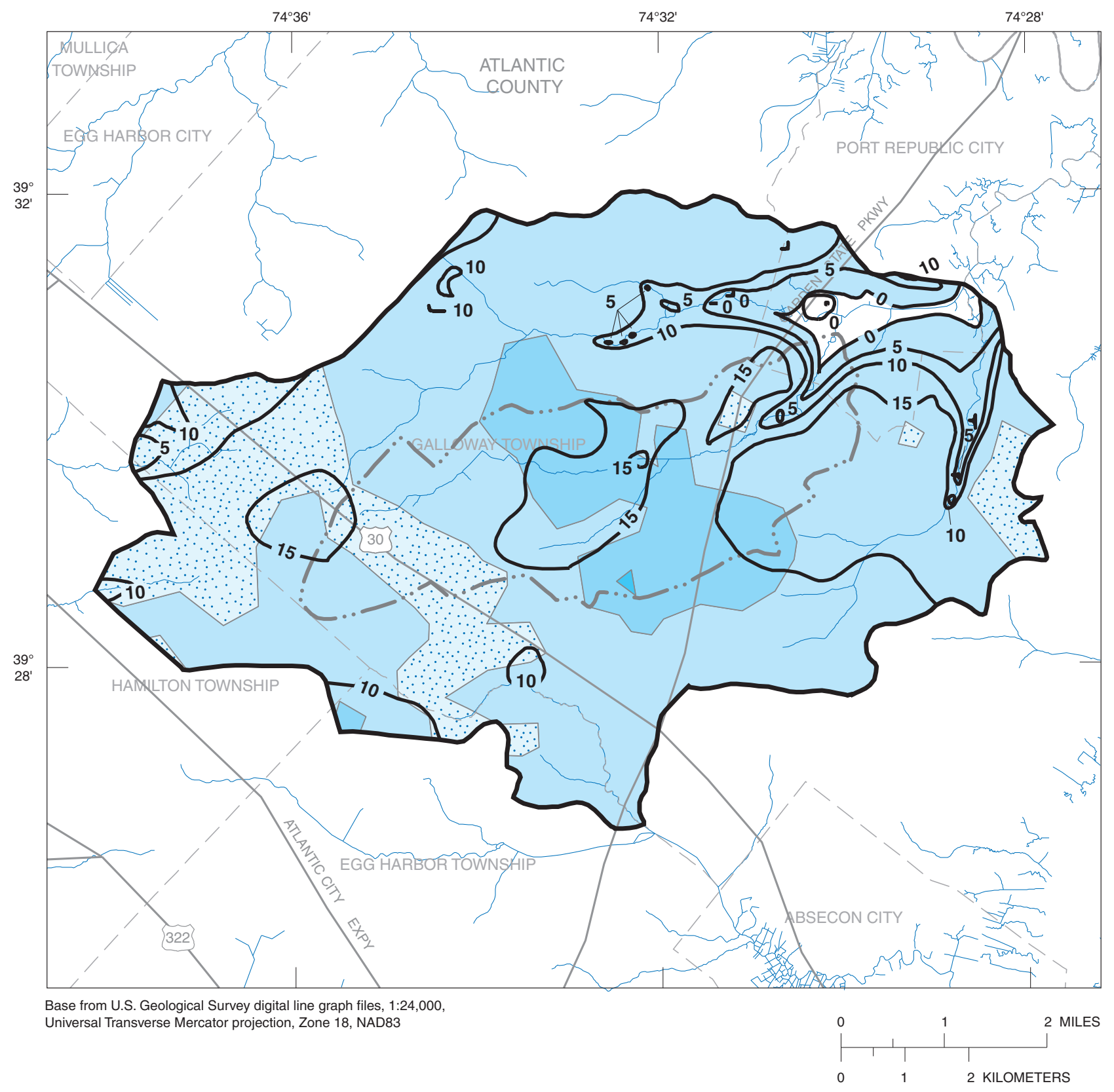

EXPLANATION

Estimated sand content in the MM A-1C1 leaky confining layer

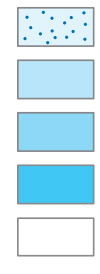

Mostly sand

More sand than clay

Sand and clay

More clay than sand

Area beyond the extent of the MM A-1C1 leaky confining aquifer layer

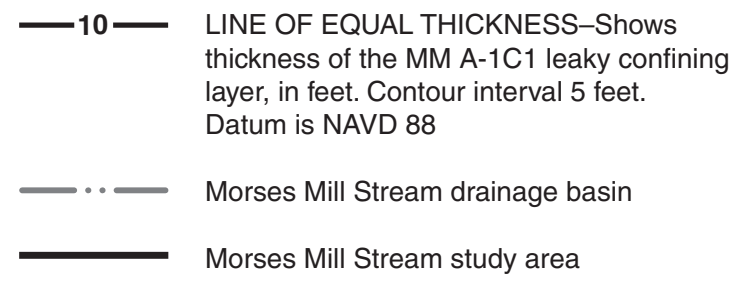

Figure 4-3. Thickness and estimated sand content of the MM A-1C1 leaky confining layer of the Kirkwood-Cohansey aquifer system, Morses Mill Stream study area and vicinity, New Jersey Pinelands. 


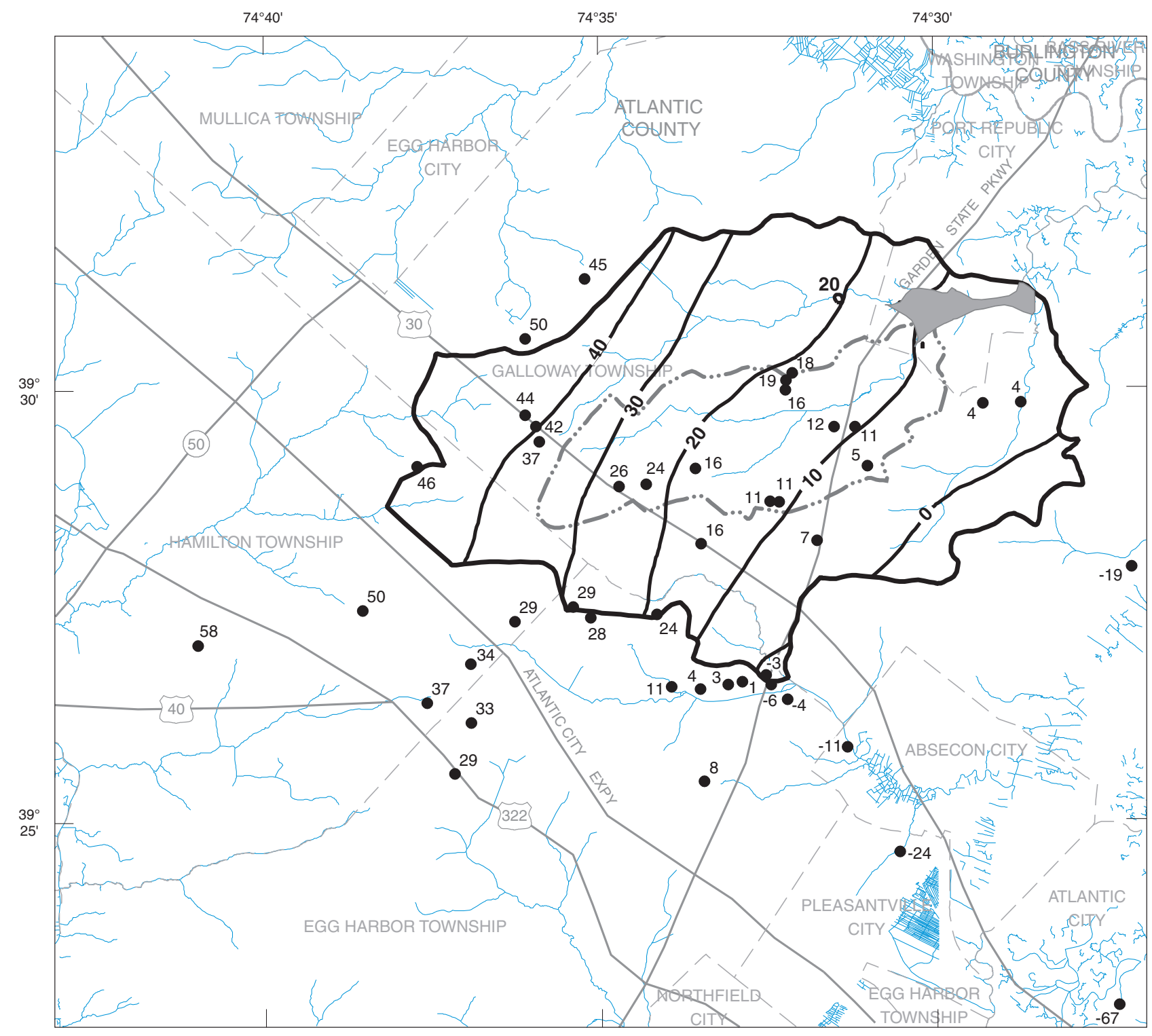

Base from U.S. Geological Survey digital line graph files, 1:24,000, Universal Transverse Mercator projection, Zone 18, NAD83

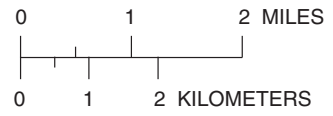

\section{EXPLANATION}

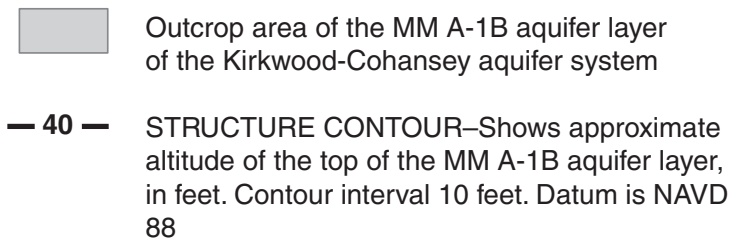
88

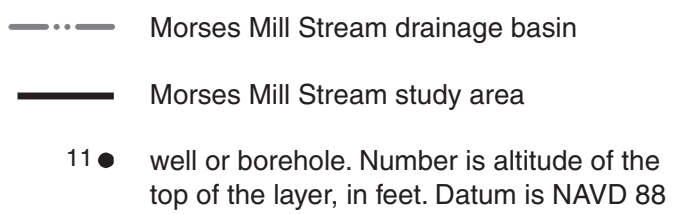

Figure 4-4. Structure contours of the top of the MM A-1B aquifer layer of the Kirkwood-Cohansey aquifer system, Morses Mill Stream study area and vicinity, New Jersey Pinelands. 


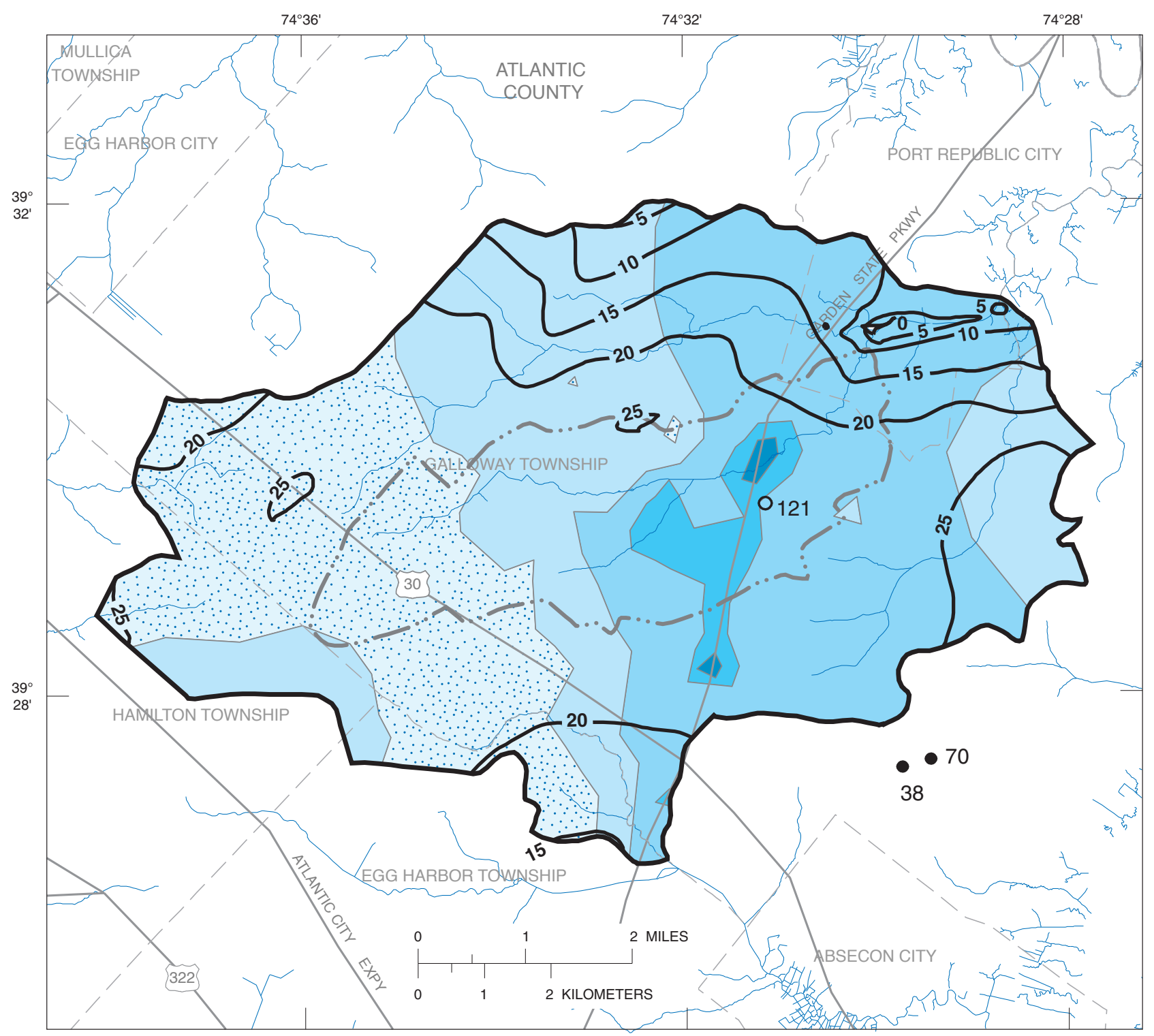

Base from U.S. Geological Survey digital line graph files, 1:24,000, Universal Transverse Mercator projection, Zone 18, NAD83

\section{EXPLANATION}

Estimated sand content in the MM A-1B aquifer layer

Mostly sand

More sand than clay

Sand and clay

More clay than sand

Mostly clay

Area beyond the extent of the MM A-1B aquifer layer
-20 LINE OF EQUAL THICKNESS-Shows thickness of the MM A-1B aquifer layer, in feet. Contour interval 5 feet. Datum is NAVD 88

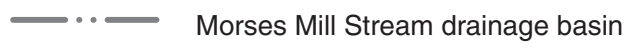

Morses Mill Stream study area

1210

Estimated horizontal hydraulic conductivity (K) derived from slug-test data, number is $\mathrm{K}$ in feet per day. (table 4)

70
Estimated horizontal hydraulic conductivity (K) derived from well-performance data, number is $\mathrm{K}$ in feet per day. (table 4 )

Figure 4-5. Thickness, estimated sand content, and horizontal hydraulic conductivity of the MM A-1B aquifer layer of the KirkwoodCohansey aquifer system, Morses Mill Stream study area and vicinity, New Jersey Pinelands. 


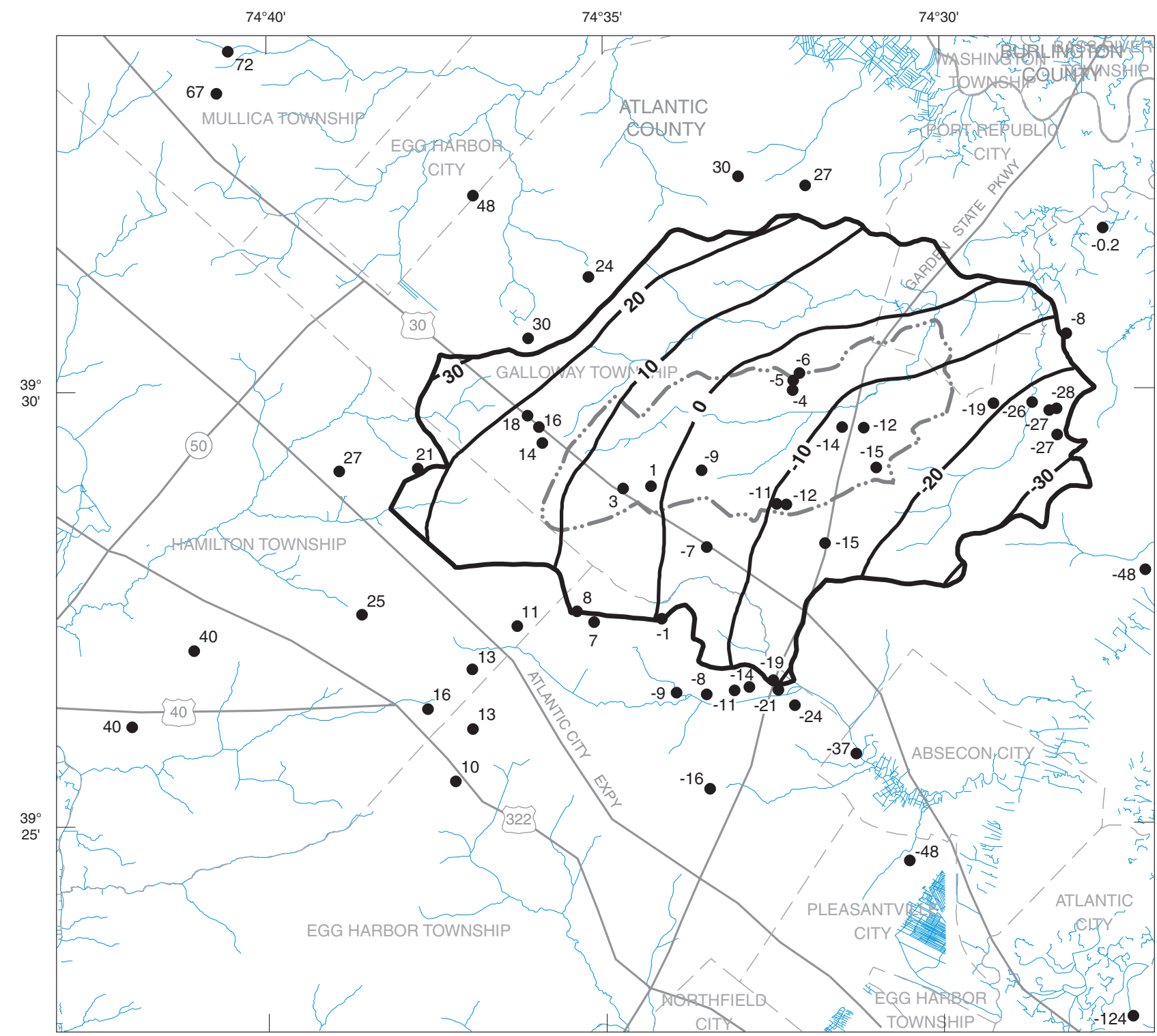

Base from U.S. Geological Survey digital line graph files, 1:24,000,

Universal Transverse Mercator projection, Zone 18, NAD83

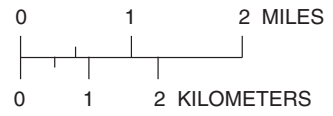

\section{EXPLANATION}

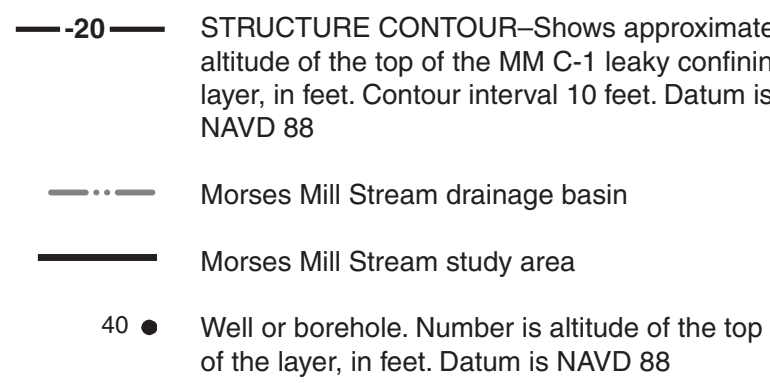

Figure 4-6. Structure contours of the top of the MM C-1 leaky confining layer of the Kirkwood-Cohansey aquifer ststem, Morses Mill Stream study area and vicinity, New Jersey Pinelands. 


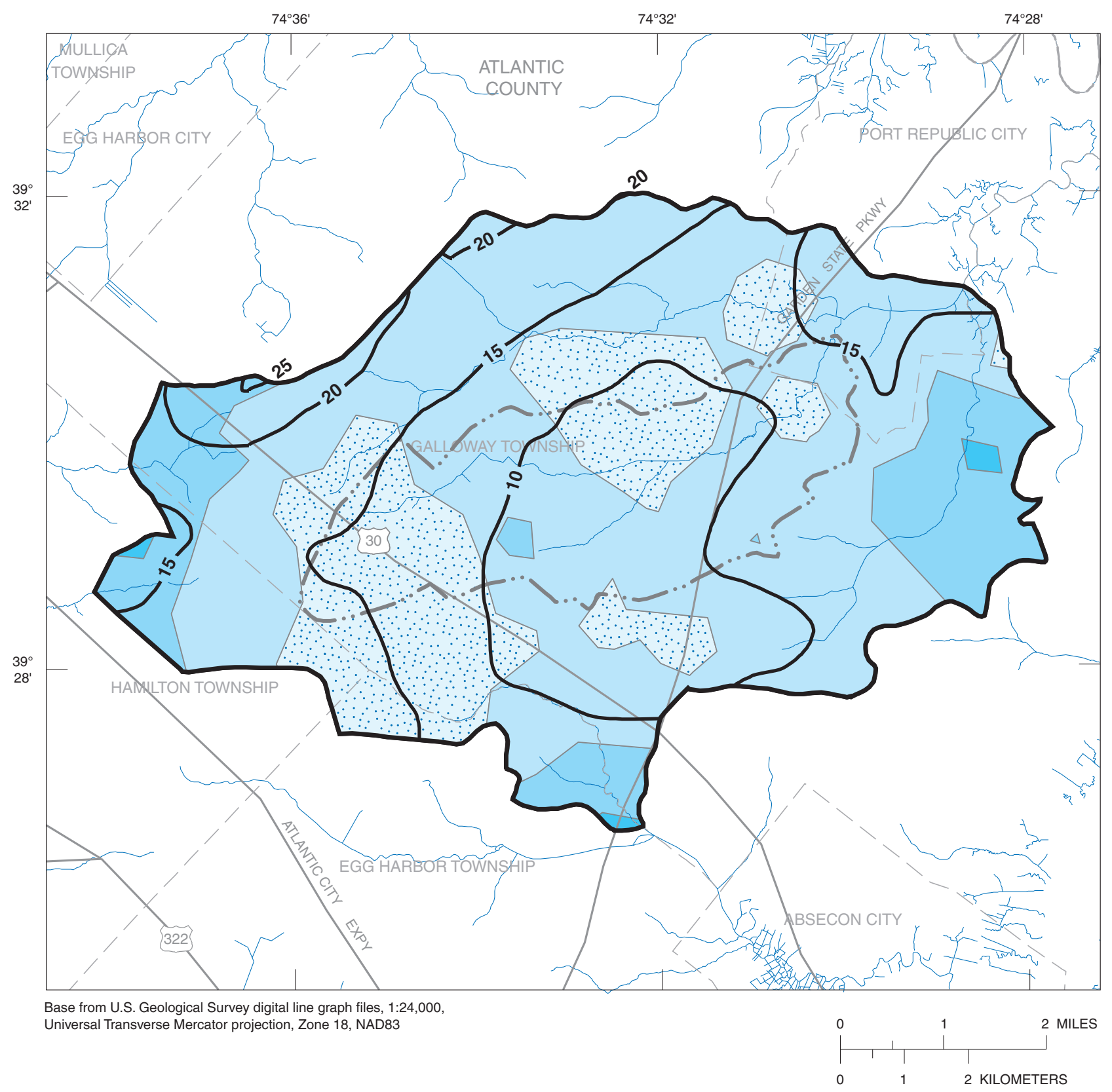

EXPLANATION

Estimated sand content in the MM C-1 leaky confining layer

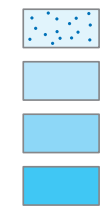

Mostly sand

More sand than clay

Sand and clay

More clay than sand

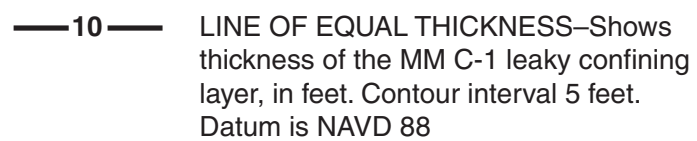

ayer, in feet. Contour interval 5 feet. Datum is NAVD 88

—_- Morses Mill Stream drainage basin

Morses Mill Stream study area

Figure 4-7. Thickness and estimated sand content of the MM C-1 leaky confining layer of the Kirkwood-Cohansey aquifer system, Morses Mill Stream study area and vicinity, New Jersey Pinelands. 


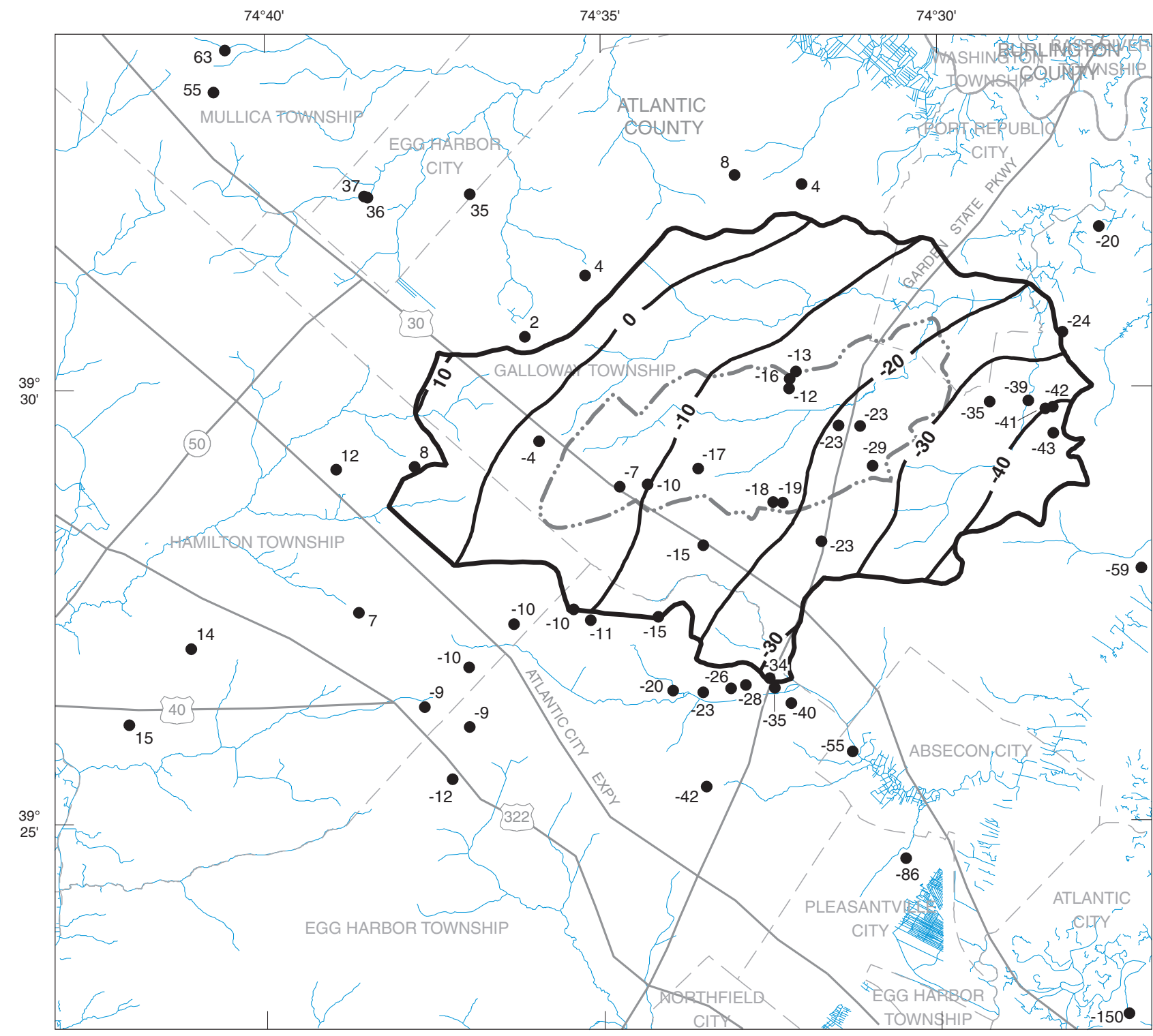

Base from U.S. Geological Survey digital line graph files, 1:24,000,

Universal Transverse Mercator projection, Zone 18, NAD83

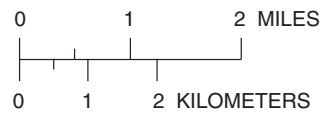

\section{EXPLANATION}

- -20 - STRUCTURE CONTOUR-Shows approximate altitude of the top of the MM A-2 aquifer layer, in feet. Contour interval 10 feet. Datum is NAVD 88

_.. Morses Mill Stream drainage basin

Morses Mill Stream study area

-20 Well or borehole. Number is altitude of the top of the layer, in feet. Datum is NAVD 88

Figure 4-8. Structure contours of the top of the MM A-2 aquifer layer of the Kirkwood-Cohansey aquifer system, Morses Mill Stream study area and vicinity, New Jersey Pinelands. 


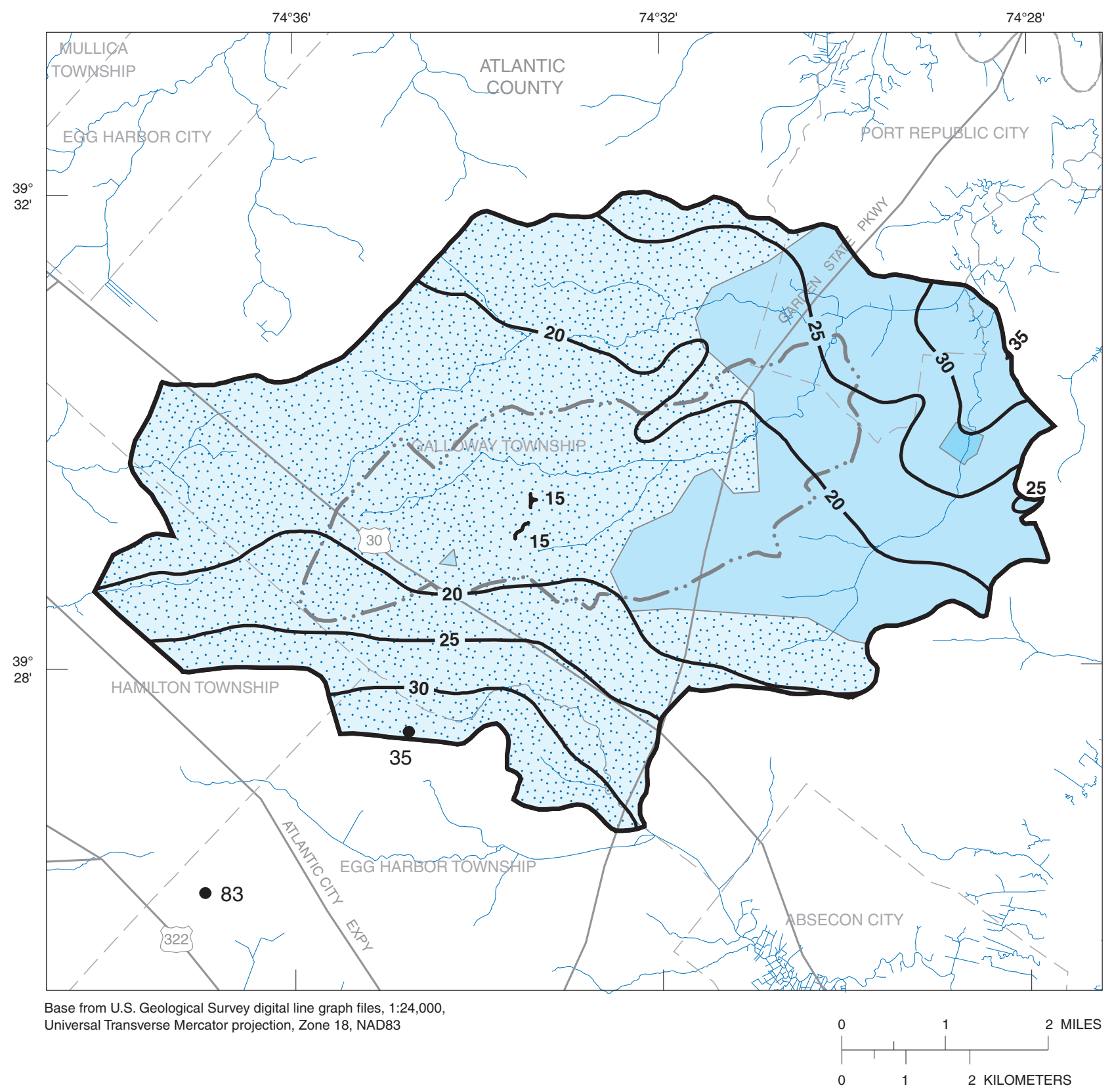

EXPLANATION

Estimated sand content in the MM A-2 aquifer layer

Mostly sand

More sand than clay

Sand and clay

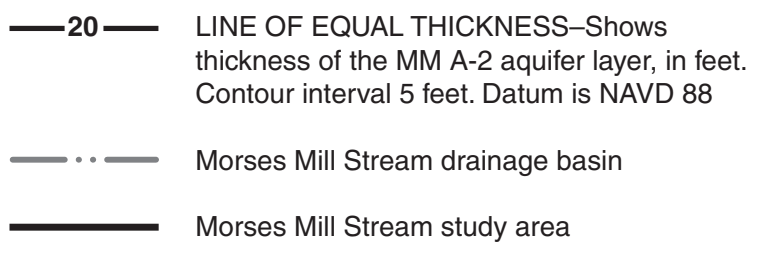

35
Estimated horizontal hydraulic conductivity (K) derived from well-performance data, number is $\mathrm{K}$ in feet per day. (table 4 )

Figure 4-9. Thickness, estimated sand content, and horizontal hydraulic conductivity of the MM A-2 aquifer layer of the KirkwoodCohansey aquifer ststem, Morses Mill Stream study area and vicinity, New Jersey Pinelands. 


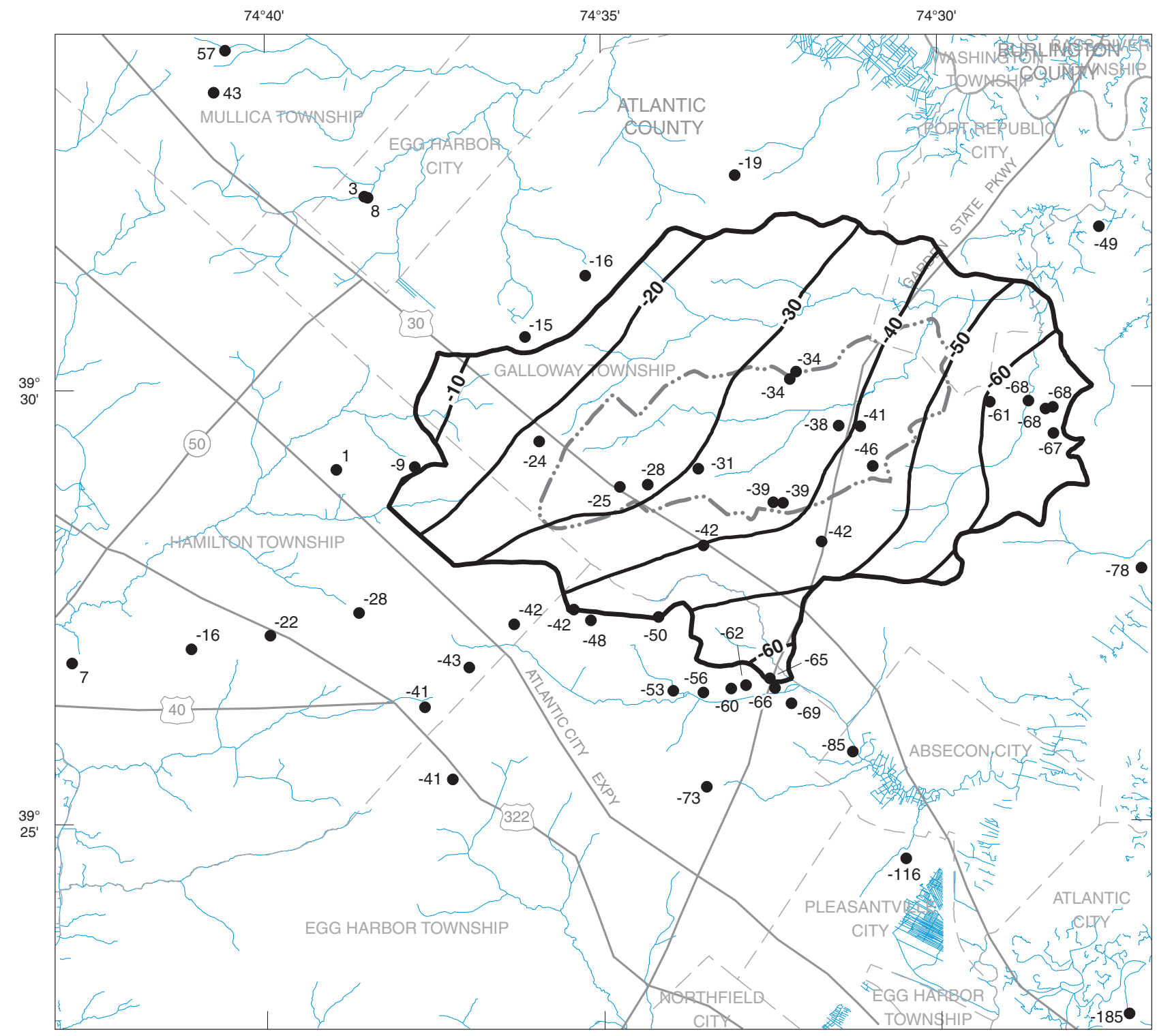

Base from U.S. Geological Survey digital line graph files, 1:24,000,

Universal Transverse Mercator projection, Zone 18, NAD83

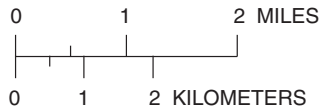

EXPLANATION

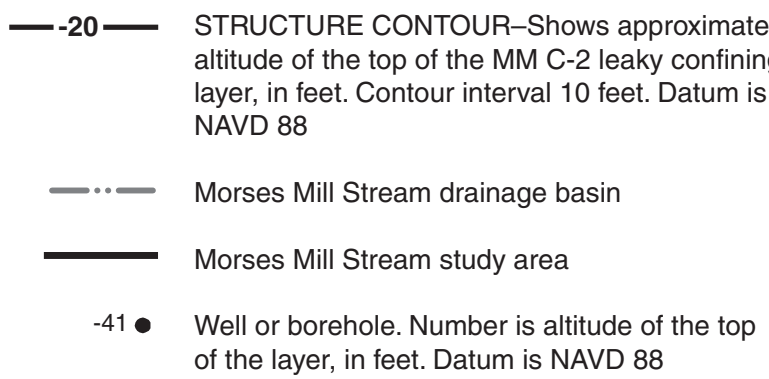

Figure 4-10. Structure contours of the top of the MM C-2 leaky confining layer of the Kirkwood-Cohansey aquifer ststem, Morses Mill Stream study area and vicinity, New Jersey Pinelands. 


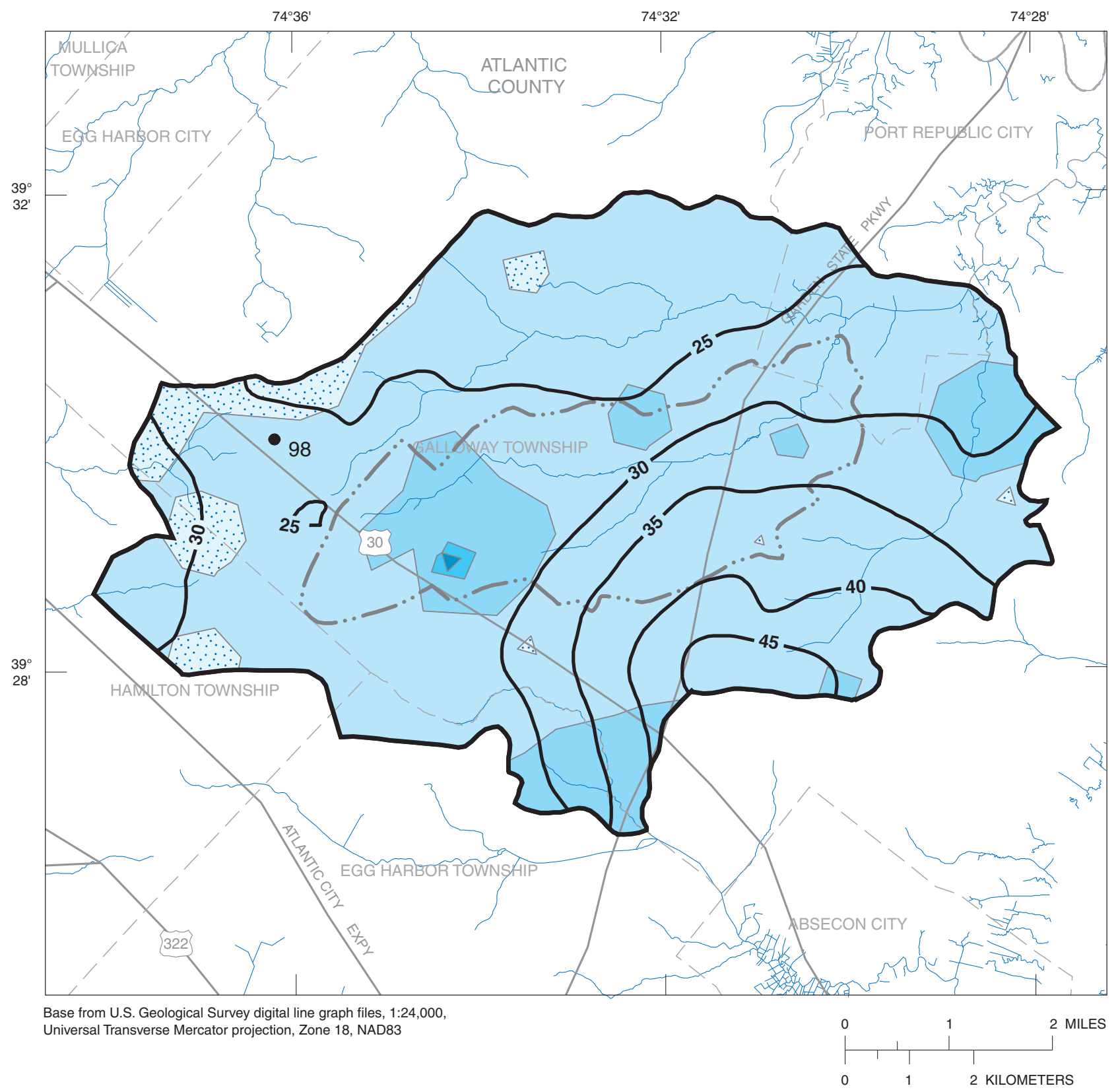

EXPLANATION

\section{Estimated sand content in the} MM C-2 leaky confining layer

\begin{tabular}{|c|c|}
\hline & Mostly sand \\
\hline & More sand than clay \\
\hline & Sand and clay \\
\hline & More clay than sand \\
\hline & Mostly clay \\
\hline
\end{tabular}

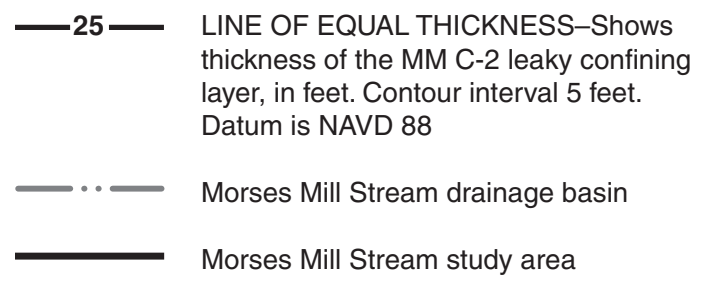

98
Estimated horizontal hydraulic conductivity (K) derived from well-performance data, number is $\mathrm{K}$ in feet per day. (table 4 )

Figure 4-11. Thickness, estimated sand content, and horizontal hydraulic conductivity of the MM C-2 leaky confining layer of the Kirkwood-Cohansey aquifer system, Morses Mill Stream study area and vicinity, New Jersey Pinelands. 


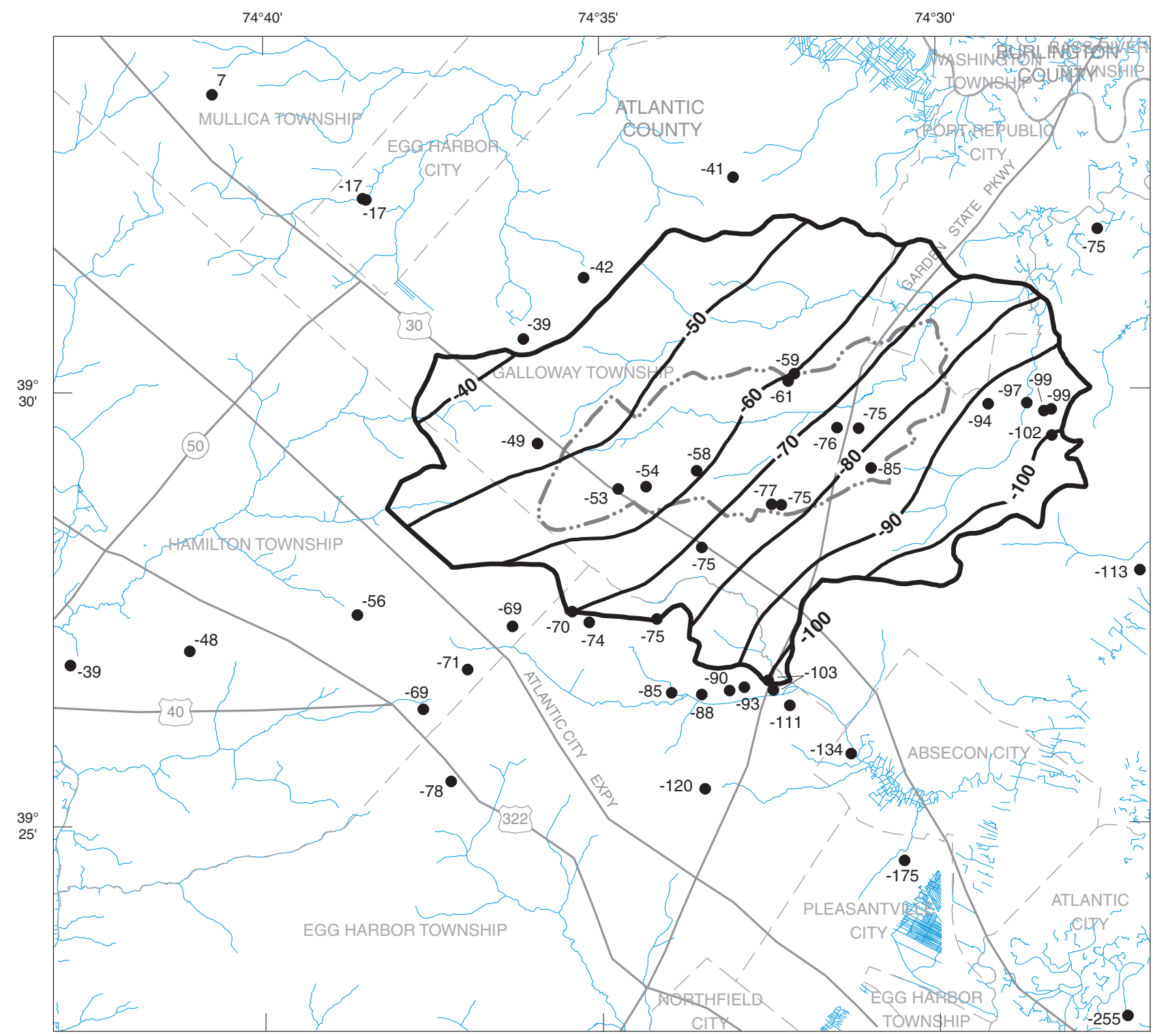

Base from U.S. Geological Survey digital line graph files, 1:24,000,

Universal Transverse Mercator projection, Zone 18, NAD83

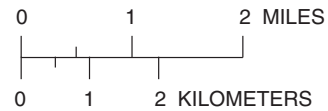

\section{EXPLANATION}

- -40 - STRUCTURE CONTOUR-Shows approximate altitude of the top of the MM A-3 aquifer layer, in feet. Contour interval 10 feet. Datum is NAVD 88

_-. Morses Mill Stream drainage basin

\section{Morses Mill Stream study area}

-85 Well or borehole. Number is altitude of the top of the layer, in feet. Datum is NAVD 88

Figure 4-12. Structure contours of the top of the MM A-3 aquifer layer of the Kirkwood-Cohansey aquifer system, Morses Mill Stream study area and vicinity, New Jersey Pinelands. 


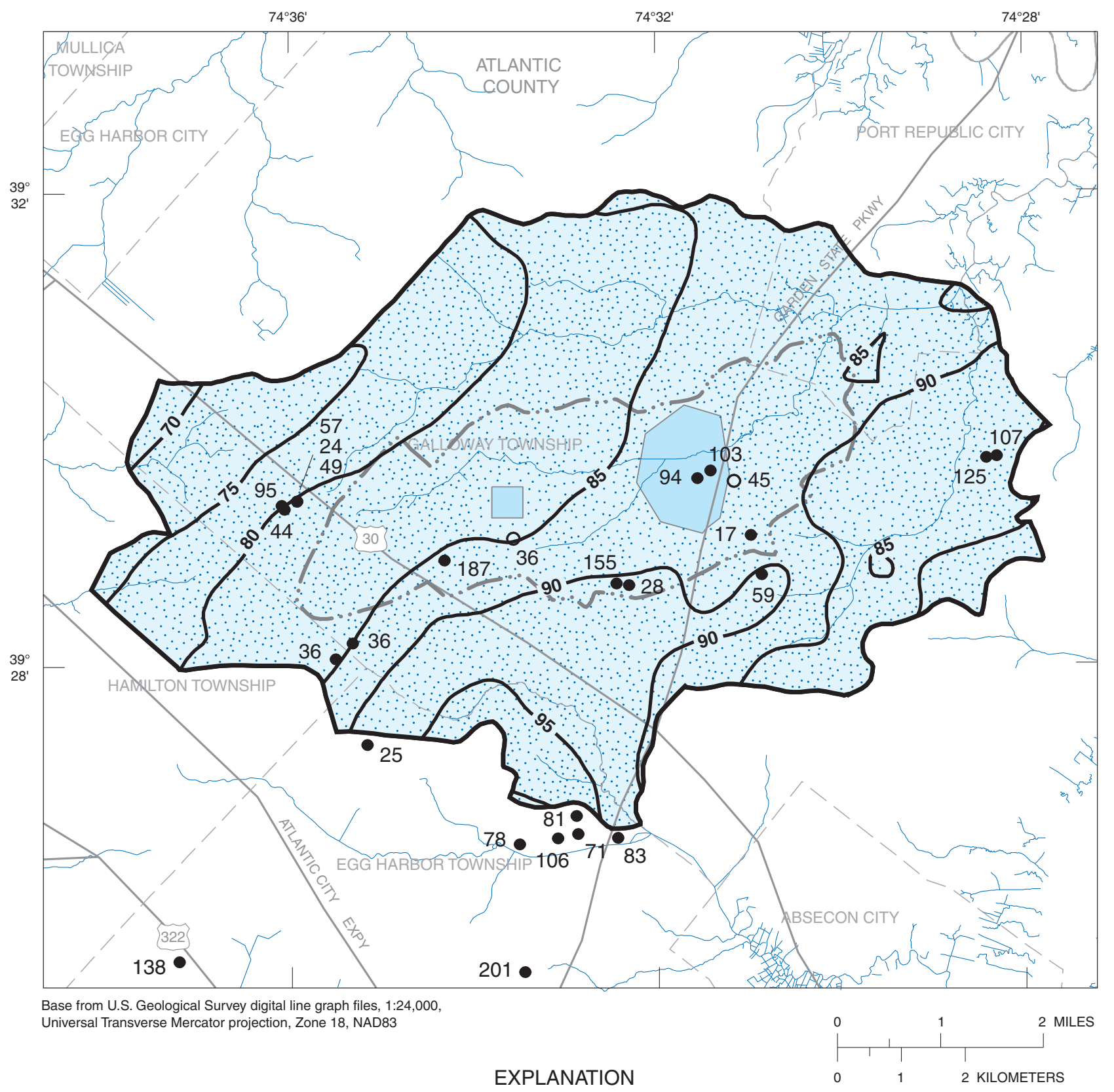

Estimated sand content in the MM A-3 aquifer layer

$\begin{array}{ll}\because \because \therefore \quad & \text { Mostly sand } \\ & \text { More sand than clay } \\ & \text { Morses Mill Stream drainage basin } \\ & \begin{array}{l}\text { LINE OF EQUAL THICKNESS-Shows } \\ \text { thickness of the MM A-3 aquifer layer, } \\ \text { in feet. Contour interval } 5 \text { feet. Datum } \\ \text { is NAVD } 88\end{array}\end{array}$

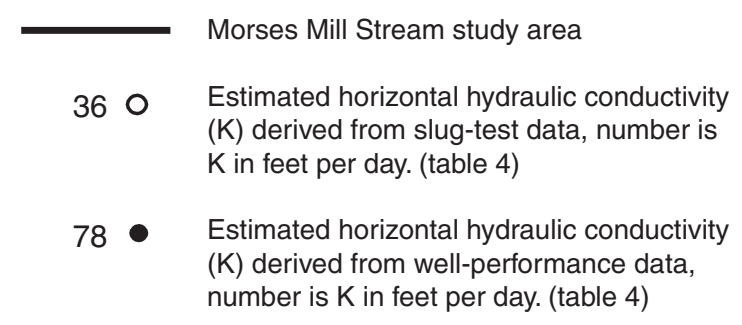

Figure 4-13. Thickness, estimated sand content, and horizontal hydraulic conductivity of the MM A-3 aquifer layer of the KirkwoodCohansey aquifer system, Morses Mill Stream study area and vicinity, New Jersey Pinelands. 


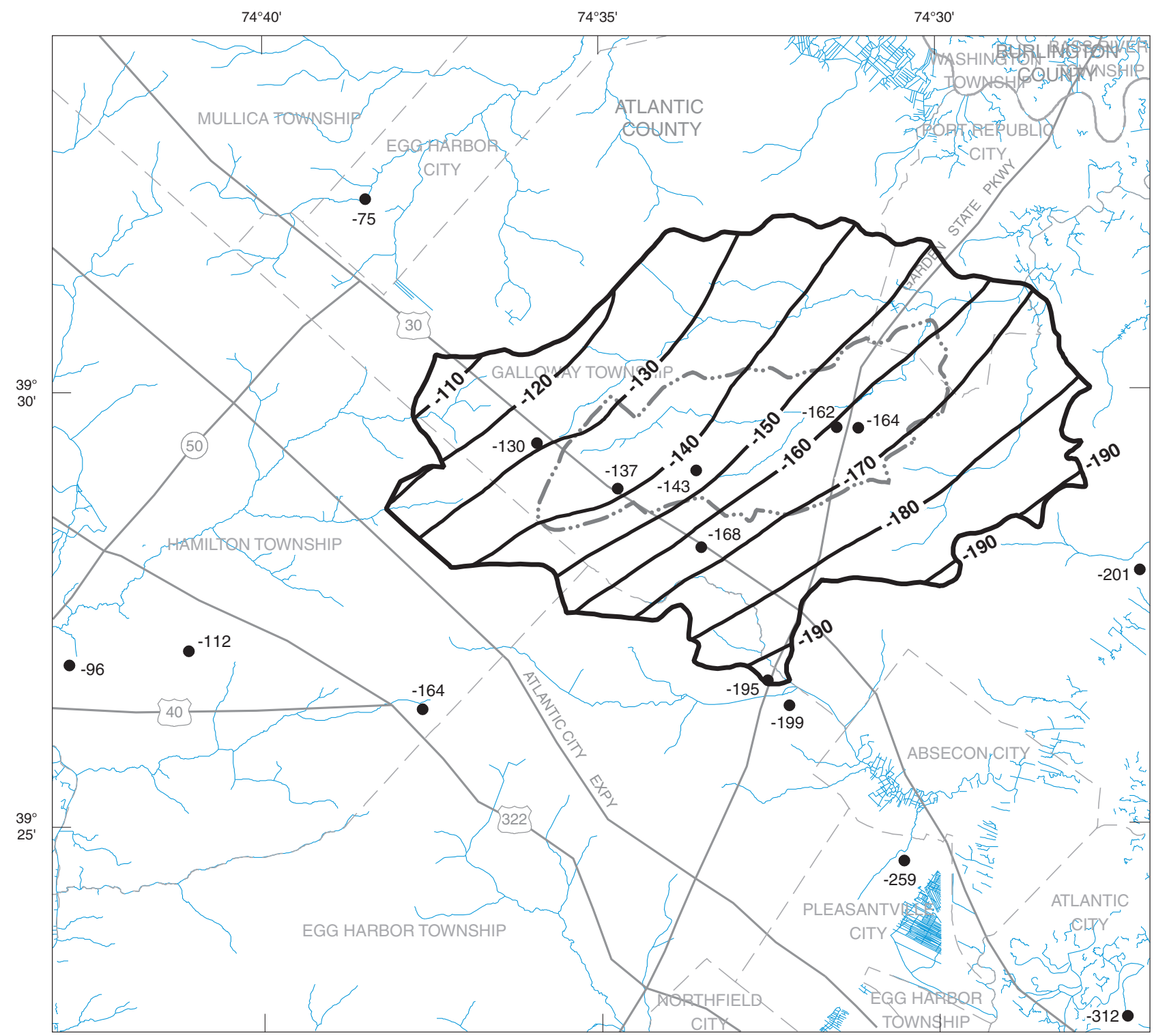

Base from U.S. Geological Survey digital line graph files, 1:24,000, Universal Transverse Mercator projection, Zone 18, NAD83

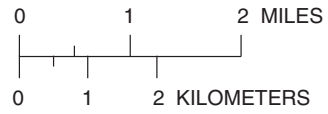

EXPLANATION

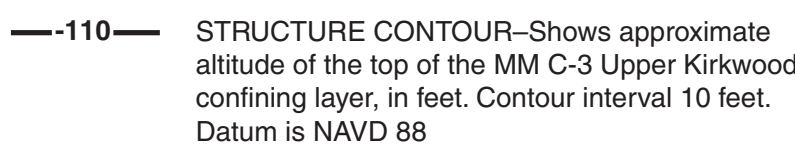

Morses Mill Stream drainage basin

Morses Mill Stream study area

-130 Well or borehole. Number is altitude of the top of the layer, in feet. Datum is NAVD 88

Figure 4-14. Structure contours of the top of the MM C-3 Upper Kirkwood confining layer of the Kirkwood-Cohansey aquifer system, Morses Mill Stream study area and vicinity, New Jersey Pinelands. 

For additional information, write to:

Director

U.S. Geological Survey

New Jersey Water Science Center

Mountain View Office Park

810 Bear Tavern Rd., Suite 206

West Trenton, NJ 08628

or visit our Web site at:

http://nj.usgs.gov/ 
